\title{
₹USGS
}

\section{Descriptions of mineral occurrences and interpretation of mineralized rock geochemical data in the Stikine geophysical survey area, southeastern Alaska}

\author{
by Cliff D. Taylor ${ }^{1}$
}

Open File Report 03-154

2003

This report is preliminary and has not been reviewed for conformity with U.S. Geological Survey editorial standards or with the North American Stratigraphic Code. Any use of trade names is for descriptive purposes only and does not imply endorsement by the U.S. Government. This report is intended for immediate release. It will be superceded by the release of this report as an integral chapter in a Professional Paper on the results of a larger body of work in the Stikine geophysical survey area.

\section{U.S. DEPARTMENT OF THE INTERIOR}

U.S. GEOLOGICAL SURVEY

${ }^{1}$ U.S. Geological Survey, Denver, Colorado 


\title{
DESCRIPTIONS OF MINERAL OCCURRENCES AND INTERPRETATION OF MINERALIZED ROCK GEOCHEMICAL DATA IN THE STIKINE GEOPHYSICAL SURVEY AREA, SOUTHEASTERN ALASKA
}

\author{
By \\ Cliff D. Taylor \\ U.S. Geological Survey \\ Central Mineral Resources Program \\ Box 25046 Federal Center, MS-973 \\ Denver, CO 80225-0046
}

\begin{abstract}
Detailed descriptions of some of the more significant mineral occurrences in the Stikine Airborne Geophysical Survey Project Area are presented based upon site-specific examinations by the U.S. Geological Survey in May of 1998. Reconnaissance geochemical data on unmineralized igneous and sedimentary host rocks, and mineralized rocks are also presented and are accompanied by a brief analysis of geochemical signatures typical of each occurrence.

Consistent with the stated goal of the geophysical survey; to stimulate exploration for polymetallic massive sulfides similar to the Greens Creek deposit, the majority of the described occurrences are possible members of a belt of Late Triassic mineral deposits that are distributed along the eastern edge of the Alexander terrane in southeastern Alaska. Many of the described occurrences in the Duncan Canal-Zarembo Island area share similarities to the Greens Creek deposit. When considered as a whole, the geology, mineralogy, and geochemistry of these occurrences help to define a transitional portion of the Late Triassic mineral belt where changes in shallow to deeper water stratigraphy and arc-like to rift-related igneous rocks are accompanied by concomitant changes in the size, morphology, and metal endowments of the mineral occurrences. As a result, Late Triassic mineral occurrences in the area appear as: 1) small, discontinuous, structurally controlled stockwork veins in mafic volcanic rocks, 2) small, irregular replacements and stratabound horizons of diagenetic semi-massive sulfides in dolostones and calcareous shales, and as 3) larger, recognizably stratiform accumulations of baritic, semi-massive to massive sulfides at and near the contact between mafic volcanic rocks and overlying sedimentary rocks.

Empirical exploration guidelines for Greens Creek-like polymetallic massive sulfide deposits in southeastern Alaska include: 1) a Late Triassic volcano-sedimentary host sequence exhibiting evidence of succession from tectonic activity to quiescence (such as conglomeratic and/or mafic volcaniclastics or flows overlain by platform carbonate or shale sequences), 2) presence and proximity to Late Triassic maficultramafic intrusions, 3) presence of quartz-carbonate-fuchsite altered ultramafic bodies, 4) pyritic, graphitic shales, 5) presence of barite and/or iron-manganese-rich carbonates, 6) low-iron sphalerite and antimony-rich sulfosalt minerals, 7) a geochemical signature including $\mathrm{Fe}-\mathrm{Zn}-\mathrm{Pb}-\mathrm{Cu}-\mathrm{Ag}-\mathrm{Au}-\mathrm{Sb}-\mathrm{Hg}-\mathrm{As}-\mathrm{Cd}-\mathrm{Ba}-\mathrm{Mn}-\mathrm{Mo}-\mathrm{Tl}$ and the ultramafic-related
\end{abstract}


suite of elements $\mathrm{Ni}-\mathrm{Cr}-\mathrm{Co}$, and 8) a geophysical signature characterized by the coincidence of a sharp resistivity contrast with evidence for buried intrusive rocks. Critical factors for the development of larger, economic orebodies are significant thickness of pyritic, graphitic shale indicating that a locally reducing sedimentary setting was established and that accumulation of an insulating shale blank occurred, and proximity to Late Triassic aged hypabyssal mafic-ultramafic intrusive rocks.

\section{INTRODUCTION}

This report presents descriptions of twenty-five mineral occurrences and preliminary interpretations of their associated anomalous metal geochemical signatures. The descriptions consist of four sections detailing the location, host rocks, morphology and mineralogy, and geochemistry of each occurrence. The first three sections of each description are based on the author's observations at the occurrences during fieldwork in May 1998 and, for a subset of the occurrences, during the summers of 1992 and 1993. Where available, previous descriptions and interpretations are incorporated and discussed in light of the new information generated during the present survey. Also presented are tables containing the unedited results of ICP-40 (inductively coupled plasma atomic emission spectroscopy-40 elements), ICP-10, Au (atomic absorption spectrography after fire assay), $\mathrm{Hg}$ (cold vapor), and $\mathrm{CO}_{2}$ (by difference) on rock samples collected within the boundaries of the present study area.

Table 1 contains the results of analyses of non-mineralized igneous country rocks, Table 2 contains the results of analyses of non-mineralized black shales primarily collected in close proximity to mineralized occurrences, and Table 3 contains the results of analyses of mineralized rocks from the twenty two occurrences described. Only the preliminary interpretations of data in Table 3 are discussed in the geochemistry section of each occurrence description. Due to the small number of mineralized samples analyzed $(n=78)$, the presence of multiple deposit types represented by the data, and the small number of analyses of samples from each occurrence, rigorous statistical evaluation of the data was not warranted. For each occurrence described, therefore, the definition of a characteristic geochemical signature is largely subjective, based upon the author's experience (Taylor and others, 1992, 1994, 1995a and b, 1999a and b, 2000a and b; Taylor, 1997). The fourth section of each occurrence description contains brief descriptions of the mineralized rock samples analyzed, and the resulting characteristic geochemical signature. The elements present in highest abundance are listed first, followed by less elevated but important elements (with regard to geochemical signature) in parentheses. Interpretive reports on the geochemical characteristics of the preTertiary igneous rocks (Taylor and others, in prep) and the Tertiary-Quaternary igneous rocks (Karl and others, in prep) will incorporate the results of high quality XRF and ICPMS geochemical analyses. Within each table, data for rocks collected in 1992, 1993, and 1998 are identified by their prefix. In all cases, the samples collected are representative of the rock type or mineralization present at the site. A small portion of each sample was retained for reference and the remainder, approximately 0.5 to 1.0 kilograms, were crushed and ground for geochemical analysis. Samples collected in 1992 and 1993 were analyzed in-house at the geochemical laboratories of the USGS in Denver, Colorado. 
Samples collected in 1998 were analyzed by contract with XRAL Laboratories in Don Mills, Ontario, Canada. Although the analytical techniques are the same, accuracy, precision, and detection limits vary between the two generations of analyses. No attempt has been made to conduct an exhaustive analysis of the statistical quality of either data set. Both data sets have passed through the quality control and quality assurance procedures in place at the USGS. For a more complete discussion of analytical methods, data statistics, and probable limits to the data sets presented, see Smith (this report) and references therein.

\section{PREVIOUS WORK}

The earliest reports on the mineral occurrences and mining activity in the Stikine geophysical study area are those of Wright and Wright (1908), Burchard (1914), Chapin (1918), Buddington (1923), and Buddington and Chapin (1929) all of which present the results of the initial geologic and mineral resource studies of the USGS in southeastern Alaska during the first quarter of the twentieth century. Reports produced during the middle third of the century are from a variety of sources and primarily describe specific occurrences in the Stikine geophysical survey area such as the Northern Copper, Taylor Creek, and Castle Island Barite occurrences (Williams and Decker, 1932; Kerns, 1950; Twenhofel and others, 1951; Race, 1963). In the last thirty years a series of compilations listing the known mineral occurrences within various geographically defined study areas has gradually increased the existing knowledge of mineral occurrences in the area (Berg and Cobb, 1967; Cobb, 1972; 1978; Karl and others, 1980; Grybeck and others, 1984; Brew and others, 1991; Newberry and others, 1997).

The most comprehensive prior study of the area was conducted during the late 1970's and early 1980's by the USGS during the Petersburg (and portions of adjoining quadrangles) Alaska Mineral Resources Assessment Program (AMRAP). In addition to the above compilations, the first faunally dated late Triassic mineral occurrence in Alaska was discovered in Duncan Canal which led to the recognition of a group of similar, probably late Triassic mineral occurrences in the Duncan Canal-Zarembo Island area (Berg and Grybeck, 1980). These authors identified the group of deposits as probable volcanogenic massive sulfide and related barite deposits, and Berg (1981) extended the concept of a metallogenic belt of late Triassic deposits to a $300-\mathrm{km}$ portion of the Alexander terrane extending from Ketchikan to Juneau. MacIntyre (1986) extended the belt to include Windy Craggy and the occurrences in the Mt. Henry Clay area of British Columbia and, based upon basalt geochemistry and the Triassic stratigraphy of the Alexander terrane, proposed a rift tectonic setting for these deposits along the eastern margin of an immature island arc-back arc basin system. Importantly, MacIntyre (1986) also proposed a genetic relationship between shallowly emplaced subvolcanic sills and the massive sulfides of the Alexander terrane. Gehrels and others (1986) also attributed the Triassic volcano-sedimentary succession along the eastern margin of the terrane to a rift tectonic environment and noted the presence of a late Triassic gabbroic intrusion in the southern end of the belt. Gehrels and Saleeby (1987a) and Gehrels and others (1987) further suggested that steeply dipping mafic dikes of probable Mesozoic age that occur 
throughout the southern Alexander terrane may have been emplaced during late Triassic rifting.

Following the discovery and (the first) successful radiogenic isotopic age determination of a late Triassic mineral occurrence in the belt on southern Admiralty Island (Taylor and others, 1992; 1995a), the present author initiated a detailed study of the entire late Triassic belt. In the context of that investigation, examination of the Duncan Canal-Zarembo Island area was made during the summer of 1993 and the resulting geochemical data and detailed descriptive information are included in this report. The most important results of the regional study to date have been to: 1) confirm the validity of the proposed extension of the belt of late Triassic occurrences into coastal British Columbia on either side of southeastern Alaska, 2) unequivocally determine the late Triassic age and association of the Greens Creek deposit, the most significant in the belt, to the other late Triassic occurrences, 3) determine the petrogenetic origins of, and demonstrate geochemical similarity between, the associated mafic volcanic rocks at occurrences throughout the belt, 4) describe and explain the variations in the stratigraphic, and tectonic settings of the occurrences throughout the belt as the result of variation in position relative to an evolving intra- or back-arc rifting event, and 5) to provide a metallogenetically coherent interpretation for the variations in the types, styles, and geochemical expressions of the occurrences throughout the belt (Taylor and others, 1995a and b; Taylor, 1997; Taylor and others, 1999a and b; Taylor and others, 2000a and b). Additional information on the terrane associations, tectonic setting, stratigraphy, and igneous geochemistry of the Triassic rocks of the Alexander terrane can be found in Brew and Ford, 1984; MacIntyre and Schroeter, 1985; Woodsworth and Orchard, 1985; Ford and Brew, 1988; 1993; Gehrels and Saleeby, 1987b; Gehrels and others, 1987; Forbes and others, 1989; Smith and Fox, 1989; Rubin and Saleeby, 1992; Taylor and others, 1992; Smith, 1993; Karl, 1993a and b; Gehrels and Berg, 1994; Plafker and Berg, 1994; Newberry and Brew, 1997; 1999; Newberry and others, 1997; and Peter and Scott, 1999.

The regional study of the late Triassic massive sulfide occurrences led to the initiation of a cooperative applied research project between the USGS and the Kennecott Greens Creek Mining Company to develop a genetic model for the Greens Creek deposit. Concepts developed and refined at Greens Creek provide important constraints on the formation of other deposits in the Stikine Project area and throughout the belt. For example, an essential feature for the development of an economic orebody may have been the deposition, during ore formation, of a thick, reducing, graphitic black shale cap (Taylor and others, 2000b). Similarly, there is a growing body of evidence that supports the involvement of mafic-ultramafic hypabyssal intrusives of probable late Triassic age in the mineral forming process. Altered gabbros and serpentinites that show geochemical relationships to the Hyd mafic volcanic rocks that commonly overlie the occurrences, probably were emplaced at shallow levels in the evolving late Triassic rift, acting as the thermal centers for the mineral occurrences throughout the belt (Taylor and others, 1995a; 1999b).

\section{REGIONAL GEOLOGY AND METALLOGENY}


A brief synopsis of the critical features of southeastern Alaska geology is presented here for the sake of providing context to the deposit descriptions that follow. Comprehensive discussions of the geology and tectonic assembly of southeastern Alaska can be found in Gehrels and Berg (1994), and Plafker and Berg (1994), and references therein. More detailed discussion of the geology of the Stikine Project area can be found in McClelland and Gehrels (1990), in Karl and others (this study), and in Haeussler and others (this study). A brief summary of the metallogeny of the late Triassic occurrences of the Alexander terrane is also included. More information can be obtained from Taylor and others (1995a and b), Taylor (1997), Taylor and others (1999a), and Taylor and others (2000a). Overviews of the metallogeny of Alaska, and more specifically of the volcanogenic massive sulfide deposits of Alaska, can be found in Goldfarb (1997) and Newberry and others (1997) respectively.

The Stikine Geophysical Project area is within the Admiralty sub-terrane of the Alexander terrane (Berg and others, 1972; 1978; Churkin and Eberlein, 1977). The terrane is an allochthonous, continent-sized piece of oceanic island arc crust that began forming in latest Precambrian time in low latitudes. By Devonian time the terrane had gone through two orogenies and a protracted period of quiescence marked by erosion and formation of extensive carbonate platforms (Gehrels and Berg, 1994). Plate motion reconstructions, faunal data, and detrital zircon studies suggest that by middle Permian the terrane was just outboard of a continental landmass and that depositional environments were characterized by shallow, tropical marine, possibly evaporitic conditions (Hillhouse and Gromme, 1984; Hillhouse, 1987; Haeussler and others, 1992; Bazard and others, 1994; Gehrels and others, 1994; Savage, 1994). Rift-fill stratigraphic sequences and bimodal volcanism along the eastern edge of the terrane (MacIntyre, 1986; Gehrels and others, 1986; 1987; Taylor and others, 1995a and b; Taylor, 1997; Taylor and others, 1999a; Taylor and others, 2000a), mark the beginning of an extensional tectonic event in latest Triassic time that either split the terrane or separated it from its low latitude offshore position, and transported it to its present position on the western North American continental margin. Accretion may have commenced by Early or Middle Jurassic (McClelland and Gehrels, 1990) or Late Jurassic (Saleeby, 1994) and continued through the middle Cretaceous as indicated by the intrusion of subduction-related magmatic-epidote-bearing plutons and the development of the Jurassic-Cretaceous Chugach accretionary prism outboard of the superterrane. New age and structural data (Haeussler and others, 1999; Karl and others, 1999; Haeussler and others, this study) suggests that a change in the vergence of contractional deformation occurred from 110$102 \mathrm{Ma}$, and that by $90 \mathrm{Ma}$ there was a significant component of margin parallel motion between the Alexander terrane and the North American margin. Collision resulted in regional metamorphism and deformation related to underthrusting of the margin. In early Tertiary time (Engebretson and others, 1985; Goldfarb and others, 1997), oblique subduction changed to right lateral transcurrent motion along the margin imparting the present structural grain to the country rock and caused the formation of numerous, subparallel, high angle, strike-slip faults that have dismembered the outboard terranes.

A belt of Kuroko/Besshi (?)-type (see Cox and Singer, 1986) volcanogenic massive sulfide (VMS) occurrences are located along the eastern margin of the Alexander terrane. Deposits within this belt include Greens Creek and Windy Craggy, the most significant VMS deposit in Alaska and the largest in North America, respectively. The 
occurrences are hosted by a discontinuously exposed, $600-\mathrm{km}$-long belt of rocks that consist of a 200-800 m thick sequence of conglomerates, limestones, marine clastic sediments, and tuffs that are intercalated with and overlain by a distinctive unit of mafic pyroclastics and pillowed flows. Faunal data bracket the age of the host rocks between Anisian (late Middle Triassic) and late Norian (late Late Triassic) time (MacIntyre, 1986; Gehrels and others, 1986; Karl and others, 1999; Taylor and others, 1999b, A. Harris, unpublished data).

The VMS occurrences show crude but systematic differences in structural appearance, chemistry, and stratigraphic setting along the belt that suggest important spatial or temporal changes in the tectonic environment. In the southern end, felsic volcanic rocks overlain by shallow water limestone characterize the lower part of the sequence. In the southern and middle portion of the belt, a distinctive pebble conglomerate marks the base of the section indicative of high-energy deposition in a near slope or basin margin setting. At the north end the conglomerates, limestones, and felsic volcanics are rare or absent and the belt is composed of deep-water sediments and mafic volcanics. This northward change in depositional environment is accompanied by a northward transition from epithermal-looking occurrences with relatively simple mineralogy, to sulfosalt-enriched VMS occurrences, and finally to $\mathrm{Cu}$-Co-enriched occurrences with larger and more clearly stratiform orebody morphologies. The geologic setting in the south is consistent with shallow subaqueous emplacement on the flanks of the Alexander arc. Northwards, the setting changes to increasingly deeper subaqueous deposition in an evolving back-arc or intra-arc rift basin.

Occurrences in the southern end of the belt just west of Ketchikan, Alaska, are typified by structurally controlled, discontinuous, vein and pod shaped bodies, and less commonly, small stratiform lenses. The occurrences are $\mathrm{Pb}-\mathrm{Zn}-\mathrm{Ag}-\mathrm{Ba}-(\mathrm{Cu})$-enriched with relatively simple sulfide mineralogy, at or near the contact between felsic volcanics and oolitic limestone. Locally the limestone is dolomitized and commonly brecciated. Breccia matrix consists of quartz and Fe-rich late dolomite cement with sparsely disseminated sulfides.

The northern end of the belt is characterized by stratiform occurrences of pyritepyrrhotite- (chalcopyrite-sphalerite) with $\mathrm{Cu}-\mathrm{Zn}-(\mathrm{Co}-\mathrm{Au})$-enrichments. They are hosted by thick sections of argillite and phyllite or are enclosed by the uppermost Triassic sequence of mafic volcanics. The best example is the giant Windy Craggy deposit in northwestern British Columbia approximately $100 \mathrm{~km}$ north of the international border. The southernmost occurrences of the northern type might be the small stratiform pyritic bodies on Woewodski and Zarembo Islands in the central portion of the belt.

Occurrences in the middle of the belt, many of which are located in the present study area (Fig. 1), are transitional and define an overlap area between structurally controlled types formed in a shallow water, near-arc setting, to those with a more stratiform appearance, formed in a deeper water, rift basin setting. Structural examples extend northwards to about the latitude of Keku Inlet and southern Admiralty Island. They include galena-sphalerite-rich breccias in limestone at the contact with felsic volcanics, and galena-sphalerite-rich mafic dikes on the Cornwallis Peninsula, and similarly mineralized mafic dikes and chalcopyrite-bornite-tetrahedrite-barite-bearing, quartz-carbonate stockwork veins in mafic volcanics in Gambier Bay. Stratiform examples include silica-barite-sulfide-sulfosalt-rich occurrences in Duncan Canal, 
Gambier Bay, and the Mt. Henry Clay area, as well as the Pyrola, Greens Creek, and Glacier Creek (Main) deposits. The Greens Creek mine, on Admiralty Island $30 \mathrm{~km}$ south of Juneau, Alaska, is the best example of the deposits in the central portion of the belt. The orebody is hosted by phyllitic footwall rocks of mafic parentage and graphiticpyritic hanging wall argillites indicative of a restricted basin depositional setting possibly distal to the arc-slope. The morphology of the deposit is clearly stratiform and the pyritesphalerite-galena-sulfosalt mineralogy is suggestive of formation at lower temperatures and shallower water depths than the occurrences in the northern end of the belt.

\section{DESCRIPTIONS OF OCCURRENCES}

\section{Northern Copper}

Location: The Northern Copper occurrence (hotlink to OFR 98-784, \# PE005) is located in Section 36 of the Petersburg D-5, 15' quadrangle on the southeastern flank of Kupreanof Mountain at an elevation of between 427 and 396 meters. Access by helicopter is downhill to the east-southeast from muskegs on the ridge top. Two drill pads are located within 30 meters north and south of a small, east-flowing creek. A third drill pad (not visited) is located 0.4 kilometers north of the creek on the steep east flank of the mountain. Development at the site is distributed around the southern drill pad and consists of a 9-12-meter-deep shaft on the pad, a short caved trench extending from the shaft northwards to the creek, and a 45-60 meter long well exposed trench extending from the shaft eastward down the mountain. A third north-south trench is located just east of the second trench and extends from the south side of the creek for about 60 meters to the south. The trench is well exposed and is about 3 meters wide with a 9-meter high exposure on the uphill side. A fourth, shorter trench is located at 396 meter elevation parallel to and another 15 meters to the east of the third. An adit, accessed from the south creek bank below the fourth trench and extending westward towards the drill pad was not visited during this investigation (Peter Bittenbender and Jan Still, US BLM, oral communication, 1998). Outcrop of mineralized rock is well exposed in the wall of the second trench, in the adit, and in the creek between the two drill pads.

Host Rocks: Outcrop at the top of the second trench, in the mouth of the shaft, and extending north into the creek is composed of a platy, well foliated, chlorite schist or phyllitic graywacke. In the second trench the greenschist is in irregular contact with actinolite-rich amphibolite skarn and a dirty white, loosely aggregated, sandy unit. Precursor rock type is uncertain but may have been a carbonate cemented quartzite or quartz-calcite vein. A meter of iron-oxide-rich gossan, which grades downward into 1-2 meters of calcite-rich marble skarn, underlie this unit. The marble is overlying and in contact with very coarse crystalline, dark green actinolite endoskarn containing disseminated to semi-massive pyrite, pyrrhotite, chalcopyrite, and hematite. Vegetation between the east end of the second trench and the uphill wall of the third trench obscures outcrop. In the creek the overlying greenschist grades through gossanous greenschist into semi-massive sulfide exoskarn. The sulfide-rich horizon is underlain by thick-bedded (5$10 \mathrm{~cm}$ thick), planar schist that is highly iron stained and has been hornfelsed to a dark 
green to reddish-black color. Hornfelsed greenschist is well exposed in the third and fourth trenches. It is locally cryptocrystalline and flinty with conchoidal fractures. A two-meter high, five-meter long, lenticular-shaped interbed of coarse-grained graywacke is exposed within the hornfelsed schist in the uphill wall of the third trench.

Occurrence morphology and mineralogy: Geologic relationships in the second trench correlate well with exposures in the creek and together suggest the presence of a shallowly dipping northward striking mineralized horizon. A 0.7-1.0 meter thick, disseminated to semi-massive sulfide horizon occurs along an irregular contact between the amphibolite and the overlying marble. The majority of the sulfides are hosted within the actinolite skarn with less abundant sulfides occurring as clots and veinlets in the marble. However, the presence of a well developed one-meter-thick layer of gossan at the upper surface of the marble indicate that locally abundant sulfides may have been present at a distance of 1.0-1.7 meters from the amphibolite-marble contact. A preliminary interpretation would suggest that either an irregularly shaped or sill-like intrusive body was emplaced into a sequence of marine sediments resulting in a footwall sequence of hornfelsed graywacke and greenschist and a hanging wall contact skarn in both the intrusive and the overlying lens of carbonate.

The sulfide-bearing amphibolite skarn consists of fine to very coarse crystalline dark green actinolite in a matrix of pyrite, pyrrhotite, hematite, and chalcopyrite. In very coarse crystalline amphibolite the actinolite is fibrous and forms radiating splays up to $3.5 \mathrm{~cm}$ in length. Sulfides occur predominantly as disseminated, anhedral, coarse crystalline, interstitial grains, and less commonly as semi-massive anhedral to euhedral clots of very coarse crystalline pyrrhotite, chalcopyrite, and specular hematite.

Geochemistry: Two samples of semi-massive sulfide in amphibolite were analyzed (98DC-13, -14, Table 3). Fe, Cu, Zn, Mn, Co, Cr, (Cd, and Ag) characterize the metal geochemistry of the Northern Copper prospect. The most metal-enriched sample contains $2.1 \% \mathrm{Cu}, 0.09 \% \mathrm{Zn}$, and $9.1 \mathrm{ppm} \mathrm{Ag}$.

\section{Wetboot (Towers Creek)}

Location: The Towers Creek occurrence, previously undocumented and locally referred to as the Wetboot occurrence, is located in Section 11 of the Petersburg D-5 15' quadrangle about 2.5 kilometers northwest of the head of Towers Arm at an elevation of about 24.5 meters. The occurrence consists of a single, house-sized boulder that is located in the middle of the Creek above a series of waterfalls. Access is by helicopter descent directly onto the boulder.

Host Rocks: The boulder is entirely composed of thin bedded, highly foliated pyritic green to gray phyllite interbedded with pyritic meta-limestone. Outcrop on both banks of the creek in the immediate vicinity of the boulder appears to be composed of similar rock type. About 30 meters upstream this unit is in contact with and is underlain by planar bedded, slightly pyritic, moderately graphitic black shale. About 0.4 kilometers downstream, from the base of the falls for another 300 meters downstream the 
stratigraphic section consists of a sequence of metamorphosed mafic volcanics, tuffs and marine sediments. The first 100-m consists of porphyritic, massive to foliated green phyllite. This changes (stratigraphically up-section?) into a mixed sequence of greenschist and black shale, and then into phyllonitic black shale. At the down-creek limit of the section examined the black shale is in contact with a distinctive, massive outcrop of very coarse crystalline, dark gray to black limestone. A one-meter-wide, flinty, fine crystalline mafic dike intrudes the black shales and cuts across the creek.

Occurrence morphology and mineralogy: The Wetboot boulder consists of thinly interbedded layers $1-15 \mathrm{~cm}$ thick of pyritic, phyllitic, quartz-muscovite-chlorite schist and pyritic, variably silicified, grayish-white limestone. The only visible sulfide mineral is pyrite, which is ubiquitous in both rock types and occurs predominantly as very fine, subhedral, disseminated grains. Locally, the pyrite is concentrated and forms semimassive bands of quartz-sericite-pyrite. In places, the pyrite in the silicified limestone bands occurs as semi-massive concentrations of coarse crystalline, nodular pyrite grains up to one centimeter in diameter; they appear to have formed as diagenetic pyrite concretions.

Geochemistry: Two mineralized rock samples from the Wetboot occurrence were analyzed. A sample of the semi-massive pyritic schist (98DC-47, Table 3) contains Fe, $\mathrm{Cu}, \mathrm{V}, \mathrm{Ni}, \mathrm{Cr}, \mathrm{Co},(\mathrm{Hg}$, As and $\mathrm{Zn}$ ). A sample of the semi-massive (nodular) pyritic silicified limestone (98DC-49, Table 3) contains Fe, Mn, V, Ni, Co, Hg, As, (Cu, Mo and $\mathrm{Cr}$ ). No single metal (other than $\mathrm{Fe}$ ) was detected at abundances greater than $0.5 \%$ in either sample.

\section{Coonrod's Zinc}

Location: A previously undocumented quartz-sulfide vein occurrence known locally as Coonrod's Zinc, is located in Section 17 of the Petersburg D-4 15' quadrangle just above the mean high tide mark on the west shore of the North Arm of Duncan Canal. Access is by boat, floatplane, or helicopter.

Host Rocks: Country rock outcropping on the beach for about 200 meters on either side of the occurrence is composed of quartz veined, highly foliated, medium gray, quartzmuscovite schist. Northwards the stratigraphy grades into a medium to dark green quartz-chlorite schist and then into a possible mafic volcaniclastic rock. South of the occurrence the quartz-muscovite schist grades into planar-bedded slightly pyritic shale.

Occurrence morphology and mineralogy: The Coonrod's Zinc occurrence consists of a vertical, massive, pinching and swelling 0.15-0.3 meter wide, sulfide-bearing white quartz vein oriented parallel to the foliation in the schist. Sphalerite, chalcopyrite, and pyrite occur within the quartz vein as sparse coarse-grained clots, and in a $0.5-5.0 \mathrm{~cm}$ wide selvage on the margins of the vein as disseminations and local coarse-grained clots in altered, silica-flooded, quartz-muscovite schist. Numerous barren $2.5-10 \mathrm{~cm}$ thick parallel quartz veins are present in the country rock for 10 meters on either side of the 
occurrence. A second larger white quartz vein is exposed on the beach 250 meters south of the Coonrod's Zinc occurrence but was barren of sulfides.

Geochemistry: Two mineralized rock samples from the Coonrod's Zinc occurrence were analyzed. A sample of the quartz-sulfide vein (98DC-40, Table 3) contains $\mathrm{Zn}$ and $\mathrm{Cu}$ at low abundances. A sample of the mineralized quartz-flooded schist (98DC-41, Table 3) contains $\mathrm{Fe}$, (As and $\mathrm{Au}$ ). No single metal (other than $\mathrm{Fe}$ ) was detected at abundances greater than $1,000 \mathrm{ppm}$ in either sample.

\section{Towers Peninsula}

Location: The Towers Peninsula occurrence (hotlink to OFR 98-784, \# PE007) is a showing located in the middle of Section 17 of the Petersburg D-4 15' quadrangle. The occurrence consists of three discontinuous, moss covered rock outcrops that barely rise above the (43 meter) elevation of the muskeg that comprises the interior of Towers Peninsula. The three outcrops are separated by $\sim 15$ meters and are oriented along a N40W trend. Access is by helicopter or by foot westward from Coonrod's Zinc occurrence for $\sim 0.8$ kilometers across the muskeg. A small pit has been dug into the southwest end of the northernmost outcrop. No other development could be found. In the late 1970's AMOCO exploration drilled a series of holes into a geophysical anomaly underlying the Peninsula in the vicinity of this occurrence. They reportedly hit several weakly mineralized massive sulfide horizons at depth (Amoco Minerals Company, 1979; Zelinski, W., 1979?; Peter Bittenbender, USBLM, personal communication 1998).

Host Rocks: All three outcrops are composed of well foliated, moderately to heavily altered, silica flooded, muscovite-, and muscovite-chlorite-schist. An additional, very prominent outcrop standing 9-12 meters above the muskeg is located about 185 meters along strike to the northwest. This outcrop consists of fresh, massive gabbro.

Occurrence morphology and mineralogy: Examination of the outcrops suggest the presence of a 1.5 meter wide by 30 meter long, weakly mineralized, steeply dipping stratiform horizon containing disseminated to locally abundant clots of sulfides in veinlets and as breccia matrix. Coarse crystalline anhedral chalcopyrite constitutes 95\% of the sulfides. Bornite and sphalerite are minor phases.

Geochemistry: Two mineralized rock samples from the Towers Peninsula occurrence were analyzed. Sample 98DC-44 (Table 3) is a moderately chalcopyrite-rich sample of silica-flooded muscovite schist from the small pit on the southwest end of the northernmost outcrop. Sample 98DC-45 is a chalcopyrite-rich sample from the bestmineralized middle outcrop. Both samples contain $\mathrm{Fe}, \mathrm{Cu}, \mathrm{Au},(\mathrm{Ag}, \mathrm{Mo}, \mathrm{Zn}, \mathrm{Co}$, and V). The two samples contain 1.4 and $3.5 \% \mathrm{Cu}$, respectively.

\section{Taylor Creek}


Location: The Taylor Creek occurrence (hotlink to OFR 98-784, \# PE006) is located in the southwest corner of Section 31 of the Petersburg D-5 15' quadrangle. The occurrence consists of several areas of irregular and discontinuous patches of mineralization in dolomitic limestone. The first area is in both creek-banks along $\sim 185$ meters of Taylor Creek about 2.4 kilometers from tidewater. Others are on and around the 133-meter high knoll just north of the creek-bank exposures. The occurrence was located in 1903 and a $\sim 6$ meter long "discovery" trench was cut into mineralized limestone in the west bank of the creek. In 1948 the U.S. Bureau of Mines drilled a total of 235 meters in four holes and cut 85 meters of surface trench in 14 trenches. The best-mineralized samples were in trenches on the knoll and contained up to $4.3 \% \mathrm{Zn}, 0.95 \% \mathrm{~Pb}$, and $1.2 \mathrm{oz} /$ ton $\mathrm{Ag}$ (Kerns, 1950). The property is currently under lease to Kennecott Exploration Company.

Host Rocks: The occurrences are hosted entirely in a massive to thin-bedded, fractured, buff-colored to light gray dolomitic limestone. The limestone is in depositional contact with and overlies a penetratively foliated greenstone composed predominantly of a chlorite-calcite- (sericite-quartz) phyllite. The units strike NW to WNW and dip shallowly to moderately to the NE. Numerous north to NNE striking dikes of probable Tertiary-Quaternary age intrude the country rock. The dikes are massive, fine crystalline, dacitic in composition (?) and have thin chill margins. A 1.0-1.5 meter thick, vertical dike striking N5W crosses the creek about 45 meters upstream of the "discovery" opencut and intrudes an irregular patch of pyrite-rich mineralized limestone. A second 0.3 meter thick dike in the creek bed about 115 meters above the opencut is suggestive of geologically recent fault movement. The dike intrudes the massive, light gray limestone in the creek bed and south bank but is truncated at the contact between the limestone and a limey phyllitic interbed overlying the limestone in the north bank.

A Carnian (early Late) Triassic age is firmly established for the limestone at Taylor Creek by a series of conodont samples collected by Kennecott Exploration and identified by Anita Harris (USGS-unpublished data). Sample locations are identified on the current geologic map of the Duncan Canal-Zarembo Island area (Karl and others, 1999). Carnian conodonts were recovered from a sample of limestone located on strike about 2.4 kilometers northwest of the creek occurrences; collections from the immediate vicinity of the opencut were barren. Two samples containing latest Early Permian conodonts, located on the ridge 1.6 kilometers to the southwest, and south of the mouth of Taylor Creek along strike 1.6 kilometers to the southeast, support the up-to-thenortheast stratigraphic interpretation of early workers (Kerns, 1950). These conodont samples also bracket the permissible age of the pillowed basaltic volcanics and phyllitic greenstone located on the ridge southwest of the occurrence and in the footwall of the Taylor Creek occurrence, respectively, between late Early Permian and early Late Triassic.

Occurrence morphology and mineralogy: Patches of mineralization in the creek bank exposures have two distinct styles of occurrence. The first and most prevalent style has been described in all previous literature and consists of irregularly distributed veins, patches, and pods of disseminated to locally enriched pyrite, sphalerite, and galena in a matrix of opaque, light gray to white dolomite gangue. Marcasite has been reported to occur at Taylor Creek, however, $\mathrm{x}$-ray diffraction analysis of suspected marcasite 
identified only pyrite in a dolomite and ankerite gangue (S. Sutley, U.S.G.S., written communication). Pyrite occurs as $\mathrm{mm}$ - to $\mathrm{cm}$-sized clots and rounded aggregates in white dolomite or in a fine crystalline groundmass of a dark gray sulfide and yelloworange sphalerite. Galena occurs as fine crystalline blebs and streaks, and less commonly as coarse crystalline remobilized clots. Although not visually identified, the strong Ag$\mathrm{Sb}$, enrichment of this assemblage described below indicates the presence of antimoniantetrahedrite, a common feature of late Triassic deposits throughout the mineral belt (C. Taylor, unpublished data). This style appears to be a replacement of the host limestone. However, the presence of rounded grains of pyrite is not a typical texture of epigenetic replacement deposits in carbonate strata, and raises the possibility that the present textural form is a result of remobilization. The best example of this style of mineralization was located in the south creek bank in a 1.5-meter thick sub-horizontal band over the top of the discovery trench.

The second style of mineralization has not been previously described and may provide critical indications of the genetic process at Taylor Creek. This style consists of matrix to grain supported rounded nodules of pyrite up to several centimeters in diameter in dolomite matrix and as irregular botryoidal crusts of pyrite growing in and on dolomitic limestone. Locally, orange sphalerite and galena are present as fine crystalline matrix and as sparse, coarse crystalline clots. The best example of this textural style is located in the north creek-bank about 185 meters upstream of the open cut. A stratiform (?) horizon about 10 meters long and roughly parallel to the creek consists predominantly of this nodular pyrite "pudding stone". Conspicuously absent are any common indicators of epigenetic replacement styles of mineralization such as discrete quartz-dolomitesulfide veins or mineralized breccias. Such nodular and botryoidal pyrite textures are likely a result of syndiagenetic replacement of limestone during carbonate sedimentation. The nodular pyrite textures and intercalation's of dolomitic limestone with sulfidic limey phyllite are similar to the mineral textures and host rocks observed at the Wetboot occurrence except on a larger scale.

Geochemistry: Four mineralized rock samples from the Taylor Creek occurrence were analyzed (Table 3). Sample 98DC-34 is a semi-massive base-metal-rich example of the first textural style described above and was hi-graded from the well-mineralized horizon over the top of the open cut. 98DC-35 is a less well-mineralized sample of the first textural style, located adjacent to the margin of the 1.0-1.5 meter thick dike 45 meters upstream from the open cut. Samples 98DC-36 and -37 were collected from the north bank occurrence of nodular pyrite 185 meters upstream from the open cut. They are pyrite-dolomite-, and pyrite-dolomite-sphalerite-galena-rich, respectively. All four samples have a similar geochemical signature consisting of $\mathrm{Fe}, \mathrm{Zn}, \mathrm{Pb}, \mathrm{Ag}, \mathrm{Sb}, \mathrm{Hg}, \mathrm{Cd}$, $\mathrm{Mn},(\mathrm{Au}, \mathrm{As}, \mathrm{Cu}$, and $\mathrm{Mo}$ ). Sample $98 \mathrm{DC}-34$ contains $9.1 \% \mathrm{Zn}, 4.6 \% \mathrm{~Pb}, 4.5 \mathrm{oz} /$ ton $\mathrm{Ag}$, and extremely high values of $\mathrm{Hg}$ and $\mathrm{Sb}$. Compared to sample -34 , the nodular pyrite sample 98DC-36 contains much lower but similarly anomalous values of the elemental signature listed above, with the exception of much higher Fe, As, and slightly higher Au.

\section{Indian Point Peridot}


Location: An unnamed peridot occurrence herein informally referred to as the Indian Point Peridot occurrence is located in the center of Section 15, T. 59 S, R. 17 E, of the Petersburg D-4 15' quadrangle. The occurrence is located on the small island several hundred meters to the WNW of the old Indian Point CAA station. Access is by boat directly to the island or by foot across the tide flat from Indian Point at low tide.

Host Rocks: The occurrence consists of mantle peridotite xenoliths hosted in the blocky, columnar jointed Tertiary-Quaternary basalts that form cliffs along the shoreline of the island.

Occurrence morphology and mineralogy: Peridotite xenoliths and weathered out pockets and vacuoles that once contained xenoliths ranging up to a meter in size are liberally distributed throughout the host columnar basalt at this locality. Xenoliths are generally rounded or irregular in shape and consist almost entirely of coarse-grained aggregates of peridot with individual crystals up to 3 or 4 millimeters in diameter. Most peridots are a pale apple green color and are semi-translucent to translucent. Weathering of exposed xenoliths has resulted in partial to complete removal of the peridotite and enables separation of individual peridots by hand or small tools. Many peridots appear to be of gem quality, thus giving the occurrence potential economic significance as a mineral specimen locality. The host basalt is columnar jointed with individual columns up to several meters in diameter. The basalt occurs as in-place columns that make up the cliffs around the island and as large blocks and boulders that have fallen away from the cliff making a rubble pile at the base.

Geochemistry: Two rock samples from the Indian Point peridot occurrence were analyzed (Table 1). Sample 98DC-68 is a grab sample of peridotite from xenoliths. 98DC-69 is a sample of the massive brown columnar basalt host rock. The peridotite sample contains high values of $\mathrm{Mg}, \mathrm{Cr}, \mathrm{Co}$, and $\mathrm{Ni}$.

\section{Castle River Mouth}

Location: There are a number of small stratiform sulfide occurrences located in the large, shallow bay on the west shore of Duncan Canal at the mouth of the Castle River (hotlink to OFR 98-784, \#PE024). Several pyritic semi-massive sulfide showings located just above high tide along the shore north of the river mouth have been known since the 1920's (Buddington, 1923) and have been repeatedly mentioned in later tabulations. Two semi-massive sulfide lenses were examined in the present study and are located on the shoreline in the middle of Section 15 in the Petersburg C-4 15' quadrangle. A second occurrence, discovered by the USGS in 1980 (Berg and Grybeck, 1980), and sometimes referred to as the "Halobia" occurrence (hotlink to OFR 98-784, \#PE025) in reference to the Triassic fossils recovered from the site, was searched for in the mouth of the unnamed creek in the northwest corner of the bay and not found. Therefore descriptions and samples in this section refer only to the two semi-massive sulfide lenses located at tideline about 400 meters south of the mouth of the small creek. 
Host Rocks: The stratigraphic sequence beneath the semi-massive lenses consists of a mixed sequence of thin-foliated, siliceous, waxy, light greenish gray, chlorite-sericite schist and turbidite layers. The occurrences are within, and just below, a $\sim 2$ meter-thick horizon of stretched pebble conglomerate composed mostly of chert pebbles and clasts of the underlying turbidites and schist. At the occurrences, the conglomerate strikes N40E and dips $40 \mathrm{SE}$ into Duncan Canal. The highly foliated nature of the sediments and the stretching of the clasts in the conglomerate indicates that the section has undergone shearing, resulting in the chippy, disc-like conglomerate-rich pebbles and cobbles on the beach. The discontinuous exposure of semi-massive sulfide lenses in a relatively constant horizon relative to the conglomerate layer indicates that the occurrences likely represent stratiform semi-massive sulfides.

The same conglomerate layer is exposed in the mouth of the small creek in the northwest corner of the bay, has the same N40E, 40 SE strike and dip, and overlays a similarly mixed section of marine sediments. Moving downsection (?) up the creek to the north, country rocks consist of $\sim 100 \mathrm{~m}$ of rusty weathering thin-foliated chlorite-sericite schist in contact with $\mathrm{a} \sim 100-\mathrm{m}$-thick pyritic black argillite unit. The argillite is in contact with a massive, hackly, gray to white limestone. Up-creek further are more interbedded phyllitic turbidites and thin-bedded argillaceous limestone. Based on the marked similarity of the observations presented here with descriptions in Berg and Grybeck (1980), it is likely that the semi-massive sulfide horizon and the associated conglomerate are located stratigraphically about $200 \mathrm{~m}$ upsection from the late Triassic fossil locality. The conglomerate layer therefore represents a potentially useful marker horizon near the base of the Triassic section. A very similar potential marker of the base of the Triassic section, described below, is located on the northwest shore of Woewodski Island.

Occurrence morphology and mineralogy: The two occurrences examined consist entirely of disseminated to semi-massive pyrite in conglomeratic chlorite-sericite schist and as matrix in conglomerate. Pyrite consists predominantly of rounded 1-5 mm diameter grains in a silica-carbonate matrix or as anhedral areas of coalesced nodules. A very fine grained, disseminated, dark gray sulfide may be sphalerite. The smaller of the two occurrences is 0.6-1.0 meters thick and 1.8-2.4 meters long. The largest is roughly 1.2 meters thick and 3 meters long.

Geochemistry: Two mineralized samples from the Castle River mouth occurrences were analyzed (Table 3). 98DC-56 is a sample of disseminated to semi-massive pyrite-bearing conglomeratic greenschist from the smaller of the two occurrences. 98DC-58 is a sample of semi-massive pyrite from the larger occurrence. Both samples are characterized by a geochemical signature containing Fe, $\mathrm{Zn}, \mathrm{Pb}, \mathrm{Ag}, \mathrm{As}, \mathrm{Cd}, \mathrm{Sb}, \mathrm{Hg}, \mathrm{Mo},(\mathrm{Au})$. Both samples contain the surprisingly high $\mathrm{Zn}$ values of $1.0 \%$ and $0.3 \%$, respectively.

\section{Castle Island Barite}

Location: The Castle Island Barite deposit (hotlink to OFR 98-784, PE26, PE27) is, or was, located in a group of small islands in the middle of Duncan Canal several kilometers 
east of the mouth of Castle River. Now mined out, the deposit was found by the USGS in 1913 (Burchard, 1914), defined by diamond drill in 1931 (Williams and Decker, 1932), and mined from 1965 to 1980 (Grybeck and others, 1984). The deposit consisted of a small island almost entirely composed of barite located just east of, and connected by a small spit of land to, "Little" Castle Island; the small islet immediately south of Big Castle Island. All that remains are ruins of the loading dock on the west side of the islet, a flat loading pad and staging area on the east side of the islet, and leftover piles of broken barite. Access is by aircraft or boat to the loading pad.

Host Rocks: Little Castle Island is composed from west to east of massive, volcaniclastic, and pillowed mafic volcanics, grading into phyllitic greenstone, which grade into a thin horizon of phyllitic pebble conglomerate. Orange weathering iron carbonate alteration marks a distinctive sheared fault zone running the length of the island and exposed along the east shoreline. The eastern shore south of the loading pad consists of a sequence of phyllitic calcareous mudstone, silty limestone and possibly interbedded graywacke. This sequence is approximately 100 meters southeast of the loading pad along strike and likely represents the footwall rocks to the deposit that are now covered. A small elevated outcrop in the tide zone south of the pad and east of the Little Castle Island shoreline is composed of the calcareous phyllite. It contains, and is cut by, poddy and discontinuous sulfide-bearing quartz-carbonate veins, a few centimeters to 0.7 meters thick. Sulfides present are disseminated grains of euhedral, coarse crystalline pyrite, green (low iron) sphalerite, and minor galena. Geochemistry of the sulfide-bearing carbonate veins indicates that the carbonate is iron- and manganese-rich, as are carbonate alteration minerals associated with late Triassic mineral occurrences throughout the belt (C. Taylor, this study and unpublished data). These veins are probably the metamorphosed feeders to the Castle Island Barite deposit.

Occurrence morphology and mineralogy: Previously published records indicate that the Castle Island barite deposit was approximately 92 meters long, 61 meters wide, and extended below sea level to a depth of 45 meters (Grybeck and others, 1984). The premining maximum elevation of the barite outcrop was between 11 and 18 meters above sea level. Enclosing rocks strike northwesterly and dip $50^{\circ}$ to $60^{\circ}$ to the northeast. Premining estimates based on drilling estimated the size of the deposit down to 12 meters below sea level at 240,000 short tons and a true thickness of the main barite body of 24 to 30 meters (Burchard, 1914; Williams and Decker, 1932). These reports also suggest that the footwall to the deposit consisted of 3-6 meters of "baritic grayschist and limestone" above black slatey argillites, all of which rested on "dark volcanic rocks" which are probably equivalent to the basalt exposed on the islet to the west. Such a footwall stratigraphy is consistent with exposures of presumed footwall sediments to the southeast of the deposit, as described above. Cross-sections based on the drilling suggested that the deposit consisted essentially of a single massive lens dipping eastward, conformably with the enclosing sediments, into Duncan Canal. A horse of impure barite, calcite and schist is indicated at depth near the hanging wall. Sparse indications of hanging wall lithologies suggest phyllitic schist and meta-tuff. The northern limit of the deposit was defined by drilling; the southern boundary was not determined. The barite body was thought to " rake somewhat to the southeast and extend southerly beyond the southern tip of the 
island" (Williams and Decker, 1932), consistent with the general southeast plunge direction of fold axes in Triassic rocks of the area (Haeussler, this report).

Grybeck and others (1984) report a total production of approximately 0.75 million tons based upon undocumented sources. Their reinterpretation of unpublished drilling data and cross-sections led them to suggest that the deposit "occurred along the trough of a symmetrical open syncline trending about N70W and centered on the now mined out island, with limbs dipping 30 to 45 degrees. Drilling also indicated a considerable tonnage of lower grade barite, interbedded with grayschist (metafelsite?), chert, and graphitic schist, and indications of at least one more high grade barite lens offshore".

Texturally, samples of the baritite are massive, sugary, and white to light gray, with mm-scale bands and discontinuous wisps of fine crystalline sulfides. Examination of sulfides in thin section indicates the presence of disseminated sphalerite, galena, pyrite, pyrrhotite, bornite, tetrahedrite-tennantite, and chalcopyrite occurring as equant grains 5-300 microns in size (Berg and Grybeck, 1980; Grybeck and others, 1984).

Geochemistry: Numerous assays of drill core composite samples and surface chip samples established an average grade of $89 \% \mathrm{BaSO}_{4}$ and $4.5 \% \mathrm{SiO}_{2}$, with $0.5-2.5 \% \mathrm{Zn}$, $0.5-1 \% \mathrm{~Pb}, 1-2 \% \mathrm{Fe}, 0.5-2.0 \mathrm{oz} /$ ton $\mathrm{Ag}$, and traces of $\mathrm{Au}$ and $\mathrm{CaCO}_{3}$ (Williams and Decker, 1932; Race, 1963; Grybeck et. al., 1984). Two additional analyses of mineralized rocks are reported here (Table 3). Sample 93DC-20 consists of a cobble of typical massive barite found on the loading pad. Sample 98DC-20 is representative of the quartz-carbonate-sulfide veins in the footwall calcareous sediments located just south of the loading pad. The geochemical signature of the massive barite consists of $\mathrm{Ba}, \mathrm{Zn}$, $\mathrm{Pb}, \mathrm{Ag}, \mathrm{Fe}, \mathrm{Cd}, \mathrm{Sb}, \mathrm{Sr},(\mathrm{Cu}, \mathrm{Au}$, and $\mathrm{Mo})$. The quartz-carbonate-sulfide veins in the footwall have a similar signature with the notable addition of $\mathrm{Mn}, \mathrm{As}, \mathrm{Hg}$, and a maficultramafic associated suite of $\mathrm{Co}, \mathrm{Cr}, \mathrm{Ni}$, and $\mathrm{V}$. The geochemical signature of the veins consists of $\mathrm{Zn}, \mathrm{Pb}, \mathrm{Ag}, \mathrm{As}, \mathrm{Hg}, \mathrm{Cd}, \mathrm{Sb}, \mathrm{Mn}, \mathrm{Sr}, \mathrm{Co}, \mathrm{Cr}, \mathrm{Ni}, \mathrm{V},(\mathrm{Cu}, \mathrm{Au}$, and $\mathrm{Mo})$.

\section{Junior Creek}

Location: The informally named Junior Creek occurrence is located at an elevation of approximately 30 meters on the eastern side of the Duncan Canal, due east of the Castle Island Barite deposit in Section 26 of the Petersburg C-4, 15' quadrangle. The occurrence is approximately 10 meters off the east side of the main logging road, on the north side of a small creek that flows through a culvert under the road about one kilometer north of the end of the road. Access is by vehicle on the logging roads, by helicopter, or by boat to the shoreline and then a steep ascent by foot up the creek. The occurrence is marked by a distinctive 2-m-thick band of reddish-orange weathered alteration in black argillite.

Host Rocks: From the road eastward up the creek to an elevation of approximately 92 meters, a distance of roughly 200 meters, the country rock enclosing the Junior Creek occurrence are a platy, thinly foliated, graphitic, pyritic, black argillite. A thin lens approximately 30 meters east of the main occurrence is weakly mineralized and has a dark to light gray color that may be indicative of silica-barite flooding of the argillite. 
Country rock exposed in the creek to the west, below the occurrence all the way to the shoreline, consists of an interbedded sequence of graphitic, pyritic, black argillite, light gray calcareous phyllite, and a distinctive porphyritic, light gray to greenish-tan, lapilli tuff.

Occurrence morphology and mineralogy: The main sulfide lens that crops out just east of the road is approximately 2-m-thick, 4-m-long, and is conformable to the steeply dipping foliation. A second lens approximately $15-\mathrm{cm}$-thick is located just east of, and parallel to, the main lens. The first two lenses are composed nearly entirely of semi-massive pyrite with a phyllitic gangue of sericite, chlorite, silica, and carbonate. A third lens of uncertain thickness and continuity is located approximately 30 meters east of the others and, in contrast, is composed primarily of a light to dark gray silica-carbonate-barite-rich phyllitic argillite. The argillite section beneath (west of) the road is characterized by a high pyrite content, resulting in a red flocculant of Fe-oxyhydroxide coating the creekbed. In the larger creek parallel to and 200 meters southeast of Junior Creek, the stratigraphic relationships are consistent and a fourth area of weak silica-carbonate-barite veining occurs in the carbonaceous phyllites and tuffs below the road. Several large mineralized boulders occurring as float were also observed in the vicinity of the Junior Creek occurrence. A 1.5-meter diameter boulder, located just out of Junior Creek on the southeast bank, was noted and was composed of heavily iron-stained, coarse crystalline, pyritic gabbro. A second boulder of quartz-carbonate- sulfide veined white to light gray limestone was noted below the road in the larger creek to the southeast of Junior Creek. The rock contains veinlets and clots up to centimeter-size of chalcopyrite, pyrite, and a dark gray mineral, probably sphalerite or tetrahedrite. There were a number of pieces of float the largest of which was 1 x 2 meters in size.

Geochemistry: Five mineralized samples were analyzed from the Junior Creek occurrence (Table 3). Sample 98DC-22 is from the main lens of semi-massive pyrite. Sample 98DC-25 is from the lens of silica-carbonate-barite-rich argillite that is located 30 $\mathrm{m}$ above the main lens. Sample 98DC-26 is from the pyritic gabbro boulder, sample 98DC-29 is from the chalcopyrite-rich limestone boulder, and sample 98DC-30 is a carbonate barite-veined crystal lapilli tuff from outcrop in the larger creek below the road. The semi-massive sulfide is characterized by a Fe, Ni, V, Co, Cr, As, ( $\mathrm{Hg}, \mathrm{Ag}, \mathrm{Au}$, $\mathrm{Mo}$, and $\mathrm{Sb}$ ) geochemical signature very similar to that of the enclosing shales. The two silica-carbonate-barite-rich samples have similar signatures characterized by $\mathrm{V}, \mathrm{Ni}, \mathrm{Cr}$, (Co, Mn, Sr) +- Mo, Ba, (Au and Bi), also fairly similar to the host rock shales. The sulfide-rich limestone contains $\mathrm{Zn}, \mathrm{Cu}, \mathrm{Cd}, \mathrm{Mn},(\mathrm{Hg}, \mathrm{Ag}$, and $\mathrm{Sr}$ ). The pyritic gabbro contains $\mathrm{Fe},(\mathrm{Cu}, \mathrm{Ba}, \mathrm{Mn}$, and $\mathrm{V})$.

\section{Lost Show}

Location: The Lost Show occurrence (hotlink to OFR 98-784, \#PE029) is located in the northeast quadrant of Section 22 of the Petersburg C-4, 15' quadrangle less than a kilometer from the northwest point of Woewodski island. The occurrence consists of an east-west trending low ridge of rock on the north side of a small lake. The terrain around 
the occurrence is low and hummocky, consisting of a mix of open muskeg and timbered high ground. Access is by helicopter, or by foot from the cabin at the mouth of Harvey Creek. Although public literature on the Lost Show occurrence is scarce (Newberry and others, 1997), several different companies have intermittently prospected the site over the last decade. At the time of the present examination, at least three drill pads and a survey grid had been cut on the property. Two trenches had been cleared over the occurrence exposing its width at the center and at the west end of the low ridge.

Host Rocks: Surface outcrop in the vicinity is poor due to the low topography and vegetation. The host rock at the occurrence consists of schistose, heavily altered, and banded, silica-flooded greenstone. Less altered equivalents consist of quartz-sericitechlorite phyllite. Outcrop 30 meters north of the westernmost trench is an altered mafic volcanic rock.

Occurrence morphology and mineralogy: The Lost Show occurrence consists of a single, near vertically dipping 3-4 m-wide stratiform horizon of silicified greenstone. The silicified horizon contains as many as six $\mathrm{cm}$ to $0.3 \mathrm{~m}$-thick bands of pyrite-sphaleriterich, semi-massive to massive sulfide in the center trench, which coalesce into thicker bands in the west trench. The horizon is continuous along strike for at least 40 meters between the two trenches. Continuity of the lens to the east and west is unknown but is likely, based on the consistent thickness of the lens over 40 meters. The thickest and best-mineralized massive sulfide occurs in the western trench and appears to be zoned somewhat across the width of the lens. Massive sulfide against the north side of the lens is sphalerite-rich and grades into more silica-pyrite rich massive sulfide towards the southern edge of the lens. Where massive, the sulfides consist of a fine-grained mixture of pyrite, dark red sphalerite, and minor amounts of a dark gray sulfide, possibly galena or tetrahedrite. Semi-massive sulfides are texturally similar with a gangue of gray to white silica. Breccia fragments of quartz, minor vug space filled with euhedral pyrite crystals and veinlets of pyrite cutting silicified breccia fragments suggest tectonic disruption of the lens and redistribution of sulfides.

Geochemistry: A sample (98DC-32) of the sphalerite-rich massive sulfide from the western trench was analyzed (Table 3 ). It is characterized by a geochemical signature containing $\mathrm{Zn}, \mathrm{Fe}, \mathrm{Cd}, \mathrm{Hg}, \mathrm{Ag}, \mathrm{Sb},(\mathrm{Pb}, \mathrm{Au}, \mathrm{Cu}$, and $\mathrm{Mn})$ and highlighted by $16.0 \% \mathrm{Zn}, 2$ oz/ton Ag, 1700 ppm Cd, and 331 ppm Hg.

\section{Helen S (Harvey Creek)}

Location: The Helen S group of occurrences (hotlink to OFR 98-784, PE028, named for the sister or wife of Lieutenant Commander Albert S. Snow, USN, who conducted surveys in the area in 1886?) are located just inland from the cabin at the mouth of Harvey Creek on the northwestern shore of Woewodski Island. The original claims were located in 1902, and by 1907 some surface trenching, two shafts, and 198 meters of drifting and crosscutting had been completed. A 20-stamp mill and compressor plant were installed and tested, but apparently saw little use (Wright and Wright, 1908). By 
1921 the property had been abandoned for several years and the equipment dismantled following production of an unknown amount of low grade Au ore from ".... a lode of pyritized greenstone and diorite (or altered gabbro) having a width of about 40 feet (12 meters) and exposed for a length of 1,000 feet (305 meters)..." (Buddington, 1923). Originally thought to occur in Devonian rocks, Berg and Grybeck (1980) re-assigned the age of the host rocks to late Triassic based on lithologic correlation. They also described massive base-metal-rich sulfides on the dump around the mouth of the first of the two shafts and pointed out the ambiguities in previous descriptions that primarily focus on the numerous sulfide-bearing quartz-calcite veins. It is worth noting that the early accounts describe only a trace of free gold in the veins. Results of the milling test suggested that what gold was recovered was primarily associated with the sulfide concentrate (Wright and Wright, 1908; Buddington, 1923). At the time of this examination the cabin at Harvey Creek was in use by the owner who had opened a new trench immediately north of the cabin and had cleared out some of the earlier workings affording a better look at exposures in the area. Much of the quartz veining is visible in the small creek that flows north-south between the cabin and the old mill foundations. Two shafts, both flooded, are located along the east bank of the creek approximately 150 and 200 meters north of the millsite.

Host Rocks: Country rock exposed in the creek and in the new trench is predominantly an altered, quartz-calcite-veined meta-basalt. The volcanic rock occurs primarily as a blocky to poorly foliated chlorite-sericite-calcite phyllite interbedded with minor amounts of slatey, graphitic black argillite.

Occurrence morphology and mineralogy: All previous reports draw attention to numerous occurrences of what are assumed to be auriferous quartz veins. Examinations by the present author in 1993 and 1998 failed to identify free gold in any of the sparsely sulfide-bearing veins and instead have focussed on the one exposure of massive sulfide. Cursory examination of the quartz veins indicates the presence of sparse but locally coarse crystalline clots of pyrite, sphalerite, galena, and a trace of chalcopyrite. The second of the two shafts appears to have been sunk on a near vertically oriented 0.3 meter-thick quartz vein.

A 0.5 to 1-meter-thick pod of pyritic massive sulfide, sandwiched between apparently conformable footwall and hanging wall rocks composed of highly altered greenschist, is exposed under some tree roots immediately to the east of the first flooded shaft. The massive sulfide appears to be tabular but is not well enough exposed to determine if it is in fact stratiform or even stratabound. Mineralogically the massive sulfide is composed of coarse crystalline euhedral, pyrite and larger aggregate masses of polygonal-textured pyrite with minor amounts of sphalerite and possibly galena. Gangue is primarily white quartz and lesser calcite.

The early descriptions are intriguing in that they describe the principal feature that was exploited as a 1.5-4.5 meter wide mineralized belt of greenschist about one hundred meters in length that was roughly conformable to the local stratigraphy. Mineralization within this body was described as a network of quartz-calcite stringers, which in places had a banded, flinty character. Sulfides occurred in the host rock as well as the stringer veins as disseminations and clots, composing $2-4 \%$ of the rock (Wright and Wright, 
1908). Description of the same feature as a pyritic greenstone and mafic intrusive body occurring along a strike length of 300 meters (Buddington, 1923) strengthens the interpretation of a conformable mineralized horizon and establishes an association with probable Triassic mafic-ultramafic hypabyssal intrusive body; a rift-related feature common to many of the Triassic occurrences throughout the belt (Taylor and others, 1995a; 1999; 2000a). Geochemical data (discussed below) demonstrates the similarity of the geochemical signatures of massive sulfide and vein samples to each other and to other late Triassic mineral occurrences in the belt, and confirms the uniformly low abundance of gold at the Helen S group. The combination of the described characteristics suggests to this writer that all of the mineralization is a result of late Triassic processes. The polymetallic quartz-calcite-sulfide veins on the property may well be the result of metamorphic redistribution during the Cretaceous (see age constraints for veining at the Maid of Mexico, below).

Geochemistry: Five mineralized samples were analyzed from the Helen S group of occurrences (Table 3). Samples 93DC-16, -17, -18, and 98DC-96 are all from the massive sulfide near the first shaft. Sample 98DC-97 is from a polymetallic quartzcalcite vein in meta-volcanics from the new trench behind the cabin. The geochemical signatures of all samples are similar and consist of $\mathrm{Fe}, \mathrm{Zn}, \mathrm{Ag}, \mathrm{Hg}, \mathrm{As}, \mathrm{Sb},(\mathrm{Pb}, \mathrm{Cd}, \mathrm{Mo}$, and $\mathrm{Au}$ ). Maximum enrichments in the massive sulfide are over $1 \mathrm{oz} /$ ton $\mathrm{Ag}$ and $3.5 \%$ $\mathrm{Zn}$. The polymetallic vein sample contains $2.0 \% \mathrm{Zn}$.

\section{Maid of Mexico}

Location: The Maid of Mexico mine (hotlink to OFR 98-784, \# PE031) is located in Section 23 of the Petersburg C-4, 15' quadrangle just northeast of Harvey Lake in the northwestern part of Woewodski Island. Access is by foot along a faint trail from the northeast shore of Harvey Lake. Early reports (Chapin, 1916; Buddington, 1923) describe the property as consisting of six claims at an elevation of 120 meters and including the Maid of Mexico and northern and southern extensions. Grybeck and others, (1984) reported the property to be active in 1979, and described more than 300 meters of workings and several adits. They mention an unreferenced literature report of approximately 100 ounces of $\mathrm{Au}$ and $\mathrm{Ag}$ production, and comment that, based on the size of the dumps and the amount of workings, production was probably "well above" the 100-ounce mark. At the time of a visit to one of the adits (the Harvey Lake claim group) by the present author in 1993, a small, tarp-covered cabin was being maintained and the adit was open. The property was not examined during the present study.

Host Rocks: Host rocks consist of slatey, calcareous, graphitic, black argillites interbedded with lesser pyritic greenschist (tuff?) and limestone that has been intruded by at least one felsic dike. The argillite is in contact with greenstone and phyllites. The sequence is thought to be part of the Triassic Hyd Group (Brew, 1997a). The adit at the Harvey Lake group opens into a face of argillite on the west bank of a small creek. The adit is oriented $\mathrm{N} 20 \mathrm{~W}$ and appears to intersect a contact between the argillite and a 2-3 
m-thick felsic tuff or sill. The tuff or sill has a light tan to gray color and is cut by numerous foliation parallel white, sulfide-bearing quartz veins.

Occurrence morphology and mineralogy: All previous reports describe underground and surface exposures of a continuous, 0.6-2-m-thick white quartz vein that was traceable for 610 meters. Average width was 1.4 meters and it had a strike of east to N60E and a dip of $60-80^{\circ}$ south. The vein reportedly consisted primarily of white quartz and minor calcite, and contained pyrite, sphalerite, galena, chalcopyrite, and free gold. Wall rock selvages and inclusions of country rock in the vein were sulfidized and ore bearing. The vein was located variably in and adjacent to "porphyry" or "dolomite" and was thickest when occurring along the contact of the argillite with these rock types. Veining within the sill or carbonate unit is described as wider and less continuous. As described above, the adit examined in this study appears to crosscut a felsic sill or tuff oriented N75E dipping $66^{\circ}$ southeast. A surface outcrop of the sill is accessible approximately 50 meters north up the creek on the west bank. The sill is highly sheared, pyritic, and contains foliation parallel, 1-cm thick sulfide-bearing white quartz veins spaced three or four to a meter. The altered sill contains euhedral pyrite several millimeters on an edge and pyrite, sphalerite and chalcopyrite are visible in the quartz veins. Alteration minerals consist of abundant sericite and lesser calcite and fuchsite.

Geochemistry: Four mineralized samples were analyzed from the sulfidized sill outcropping north of the adit (Table 3). Three samples 93DC-08, -09, and -11 represent the sulfidized felsic sill or tuff. Sample 93DC-10 is a pyrite-chalcopyrite-calcite-sericitefuchsite vein cutting the sill or tuff. A geochemical signature containing $\mathrm{Fe}, \mathrm{Au}, \mathrm{As}, \mathrm{Cr}$, $(\mathrm{Ag}, \mathrm{Cu}$, and $\mathrm{Zn}$ ), characterizes all four samples. The quartz vein sample contains 1.1ppm Au.

$\mathrm{A}^{40} \mathrm{Ar} /{ }^{39} \mathrm{Ar}$ age determination was made on a fuchsite mineral separate from a large block of fuchsite-sericite-sulfide-rich quartz-carbonate vein material on the dump. The sample yielded a step release spectra with a well-defined plateau age of $92.0+-0.2$ Ma composed of five steps, which account for $69 \%$ of the gas released (C. Taylor and L. Snee, unpublished data). The plateau age agrees well with the total gas age of $91.2+-0.2$ Ma. The age of the Maid of Mexico auriferous quartz vein has interesting implications for gold metallogeny in the Stikine geophysical survey area. The $92 \mathrm{Ma}$ age is clearly different from the age of both the Juneau gold belt (55 +- 2 Ma; Goldfarb and others, 1997) and the Chichagof district (52 to $50 \mathrm{Ma}$; Taylor and others, 1994), the two main periods of mesothermal gold mineralization in the region. The mid-Cretaceous age is consistent with the age of collision of the Alexander terrane with the North American margin and reflects the age of formation of gold-bearing metamorphic quartz-carbonate veins in the area. This data, therefore, provides some of the first evidence for a minor mid-Cretaceous mesothermal gold mineralizing event in southeastern Alaska that is unrelated to tectonic events in the Tertiary. It is also likely that this metamorphism and fluid flow event would have modified and locally remobilized metals from the late Triassic massive sulfide occurrences in the area, such as the Helen S group one kilometer to the west. 


\section{Harvey Lake East}

Location: A brief search was made for a previously undescribed occurrence reported to be in a small drainage immediately east of the small lake in Section 25 of the Petersburg C-4, 15' quadrangle, central Woewodski Island (hotlink to OFR 98-784, \#PE034). This occurrence is here informally referred to as the Harvey Lake East occurrence. Active claim markers and a well-flagged tree at an elevation of 46 meters on the north side of the small creek draining west off of the high ground to the northeast are the only indications of activity in the area. Access is by helicopter into the muskeg east of the small lake or by foot from the east shore of Harvey Lake.

Host Rocks: Outcrop on the hillside immediately north of the small creek is a relatively unaltered mafic volcanic rock. Moving across the creek to the southeast there are minor exposures of a pyritic altered tuff which grade into a dark greenish black phyllite.

Occurrence morphology and mineralogy: The only evidence of mineralized rock at the site were several horizons of an altered, pyritic, light greenish-tan tuff interbedded with the phyllite near the contact with the mafic volcanic rocks. Pyrite is fine crystalline and sparsely distributed in thin wisps with minor fuchsite.

Geochemistry: One sample, 98DC-90, of the pyritic tuff was analyzed (Table 3). The sample contains slightly elevated Fe, V, Hg, Cr, Co, Ni, (Sb, Zn, Ba, and Mn).

\section{Harvey Lake South}

Location: The previously undescribed and informally named Harvey Lake South occurrence is located in the northeastern corner of Section 26 of the Petersburg C-4, 15, quadrangle, central Woewodski Island (hotlink to OFR 98-784, \#PE034). Access is by helicopter into a small open muskeg several hundred meters north of the occurrence and then by foot up a small drainage to the south. The occurrence is located in the bed and west bank of the creek at an elevation of approximately 122 meters. At the time of the present examination the claimholder had excavated a drill pad into the west bank several meters above and north of the mineralized horizon and had set up a Winkie drill to explore the subsurface continuation of the horizon.

Host Rocks: Country rock at the Harvey Lake South occurrence is entirely composed of a blocky to moderately foliated, quartz-calcite veined mafic meta-volcanic rock. Foliation is oriented east-west and dips moderately to the north.

Occurrence morphology and mineralogy: The horizon exposed in the creek consists of a $15 \mathrm{~cm}$-thick layer of semi-massive pyrite that is conformable to foliation and apparently continuous over several meters. Within that band there is at least one area of 2-3 cmthick fine crystalline massive pyrite in quartz gangue. A second location approximately 150 meters south up the creek bed is marked by reddish alteration and is cut by sparse 2-3 mm-thick quartz-pyrite-sphalerite veinlets. 
Geochemistry: Three mineralized samples were analyzed from the Harvey Creek South occurrence (Table 3). Sample 98DC-85 is a piece of mafic meta-volcanic from the 15cm-thick horizon that contains $15-20 \%$ disseminated pyrite. Sample 98 DC-88 is a selected sample of pyritic, fine crystalline massive sulfide from the same horizon. Sample 98DC-86 is a quartz-pyrite-sphalerite veined mafic meta-volcanic from the creek exposure 150 meters to the south. The massive and semi-massive pyrite samples have slight enrichments of Fe, $\mathrm{Zn}, \mathrm{Au}, \mathrm{Ag}, \mathrm{As}, \mathrm{V},(\mathrm{Hg}, \mathrm{Bi}, \mathrm{Cd}, \mathrm{Cu}, \mathrm{Sb}$, and $\mathrm{Mn}$ ). The vein sample has a similar geochemical signature with higher $\mathrm{Zn}, \mathrm{Hg}$, and $\mathrm{Cd}$, and lower $\mathrm{Au}$, $\mathrm{Ag}$, As, and $\mathrm{Bi}$; zinc content is $1.3 \%$.

\section{Butterworth Island}

Location: The Butterworth Island occurrence (hotlink to OFR 98-784, \# PE035) is located just south of the southeastern corner of Section 34, of the Petersburg C-4, 15' quadrangle. The occurrence is located below the high tide line in the isthmus that separates the southeastern end of Butterworth Island from the small islet to the south. The Hattie vein gold occurrence (OFR 98-784, \# PE032) is just to the east across Whiskey Pass.

Host Rocks: Rocks exposed at low tide between the islands consist of foliated, reddish, highly altered siliceous schist. Immediately to the north, and forming the southern shoreline of Butterworth Island, the siliceous schist is in sharp contact with massive, fractured, unfoliated Cretaceous (?) diorite. To the south, the schist grades into a sequence of rocks mapped as Mesozoic volcanics (Brew, 1997a). The altered schist that host the occurrence grades southward into greenschist and moderately foliated mafic metavolcanics that have been intruded by sills of Cretaceous diorite. The diorite contains xenoliths of gabbro probably incorporated from the Mesozoic gabbroic intrusive body that outcrops on the northern third of Butterworth Island (Brew, 1997a). Foliation of the enclosing schist is oriented $\mathrm{N} 80 \mathrm{~W}, 45^{\circ} \mathrm{S}$.

Occurrence morphology and mineralogy: The occurrence consists of several subparallel 1-10 cm-thick, semi-massive to massive, sulfide bands that are conformable with foliation and occur over a width of approximately 4 meters. The mineralized bands were traced along foliation across the entire width of the low tide land bridge. The better, more massive sulfide bands are located at low tide on the east side. The best single band of mineralization was a $10 \mathrm{~cm}$-thick band of massive pyrite, dark red sphalerite, galena, and probable tetrahedrite. Texturally the sulfides are fine crystalline and equigranular and appear to occur as matrix to clasts of white quartz or chert pebbles and very elongate fragments of thoroughly altered rock.

Geochemistry: Two samples of semi-massive to massive sulfide were analyzed from the Butterworth Island occurrence (Table 3). Sample 98DC-92 is from a 2-cm thick quartz rich band near the middle of the land bridge. Sample 98DC-94 is a piece of the sphalerite-rich $10 \mathrm{~cm}$-thick band from the eastern edge of the occurrence. The 
geochemical signature of both samples is characterized by strong enrichments of $\mathrm{Zn}, \mathrm{Fe}$, $\mathrm{Pb}, \mathrm{Ag}, \mathrm{Hg}, \mathrm{Cd}, \mathrm{Sb}, \mathrm{Co}, \mathrm{Mn},(\mathrm{Cu}, \mathrm{Au}, \mathrm{Mo}$, and V). Sample 98DC-94 is the most highly mineralized sample in the Stikine geophysical survey area and contains $16.9 \% \mathrm{Zn}, 5.1 \%$ $\mathrm{Pb}, 23.5 \mathrm{oz} / \mathrm{ton} \mathrm{Ag}, 71.2 \mathrm{ppm} \mathrm{Hg}$, and 545 ppm Sb.

\section{Brushy Creek}

Location: The Brushy Creek occurrence (hotlink to OFR 98-784, \# PE033) is located in the southwestern quadrant of Section 1 of the Petersburg C-4, 15' quadrangle. Several drill pads have been cut at the 55-61 meter elevation on the southeast side of the creek. Access is by helicopter into one of the drill pads and then northwest by foot to the creek, or by foot from tidewater. At the time of this examination there were cleared survey lines between the creek and the drill pads, providing easy access. Two mineralized open cuts in the southeast bank are located approximately 50 meters apart and evidence of weak mineralization was present intermittently for at least 250 meters downstream. Despite the activity in the area, little is known and there are no publicly available descriptions of the occurrence.

Host Rocks: Country rock exposed in the creek banks are entirely composed of a brecciated, heavily altered, and weakly foliated mafic meta-volcanic or volcaniclastic rock. A small side drainage flowing in to Brushy Creek from the southeast side contains exposures of thin-bedded, calcareous, quartz-sericite schist with bands of semi-massive sulfide. Precursor rock type is uncertain but could have been a felsic tuff.

Occurrence morphology and mineralogy: The mineral occurrences at Brushy Creek consist of irregularly distributed areas of stockwork calcite-quartz-sulfide veins in the brecciated mafic volcanic rock. Two shallow pits in the creek bank each expose 2-3 meter-wide areas crisscrossed with veins. Similar areas of stockwork veining are intermittently exposed in the creek bank downstream for approximately 200 meters. Texturally all of the sulfides are fine to medium crystalline aggregates of pyrite, dark reddish sphalerite and lesser galena. Gangue consists of white quartz and calcite. In slightly more foliated rocks the clasts are stretched and flattened and the sulfides appear as irregular bands and wisps millimeters to one centimeter in width. In more competent volcaniclastics, sulfides are clearly paragenetically earlier than brecciation of the host rock as clasts are mineralized and are rotated within unmineralized matrix as well as cut by late quartz-calcite veinlets. Minor evidence also suggests that in addition to rotation of mineralized clasts, individual bands or stockwork veins have been folded.

Geochemistry: Three mineralized rock samples from the Brushy Creek occurrence were analyzed (Table 3). Samples 98DC-99 and 100 are from the calcite-quartz-sulfide stockworks in each of the two shallow pits. Sample 98DC-101 is the sulfide-banded quartz-sericite schist from the small side drainage 200 meters downstream of the pits. The geochemical signature of all three of the samples contains $\mathrm{Fe}, \mathrm{Zn}, \mathrm{Ag}, \mathrm{Hg}, \mathrm{Pb}, \mathrm{Sb}$, $\mathrm{Cd}, \mathrm{Mn},(\mathrm{Au}, \mathrm{As}, \mathrm{Cu}, \mathrm{Co}, \mathrm{Ni}$, and $\mathrm{V})$. The best-mineralized sample is the sulfide-banded 
quartz-sericite schist which contains $3.7 \% \mathrm{Zn}, 2.8 \% \mathrm{~Pb}$, and $3.2 \mathrm{oz} /$ ton $\mathrm{Ag}$. All three samples consistently contain elevated zinc in the $3.7-6.1 \%$ range.

\section{Kushneahin Lake}

Location: In their report, Grybeck and others (1984) refer to a broad area of vivid yellow-orange alteration as the Kushneahin Lake occurrence (hotlink to OFR 98-784, \# PE019). This area is well exposed in several creek drainages and covers the higher hillsides for several kilometers along the southeast scarp of what is here referred to as the Little Totem Massif. The area described is located in Sections 3, 2, and 35 of the Petersburg C-5, 15' quadrangle. Field examinations and samples collected for geochemistry come from the portion of the creek that flows northeastwards across the northwest portion of section 2, and from two side drainages flowing off of the Little Totem Massif. Kushneahin Lake is approximately 2 kilometers south of the area of intense alteration. Access is by helicopter into the muskegs southeast of the altered area and then by foot up the side drainages.

Host Rocks: The outcrops exposed in the creeks on the southeast side of the Little Totem Massif are composed of flat lying, thick-bedded layers of Tertiary and Quaternary flow banded rhyolite, rhyolite flow breccias, rhyolite tuff, and welded ash tuff. Spherulitic and other devitrification textures are common and the rhyolites are moderately to pervasively sericitized and chloritized.

Occurrence morphology and mineralogy: The "occurrence", as described above, is actually a broad area of intense yellow-orange alteration of rhyolite. All rocks within the altered area are pervasively impregnated with disseminated to locally veined, dark, sooty, very fine crystalline pyrite. Alteration of the pyrite to goethite and of the rhyolite to quartz-sericite-alunite and a variety of other clay minerals (?) is strikingly similar to the acid-sulfate style of alteration that accompanies epithermal hot springs and high-level gold-bearing porphyry systems such as at Summitville, Colorado. Silica alteration is minor and occurs as chalcedony with calcite. Thunder eggs composed of banded chalcedony with calcite-filled interiors were noted weathering into the creeks. The most intensely altered rock encountered was in a distinctly sulfur- yellow outcrop in the creek bed of the side drainage coming off the Little Totem Massif through the northwest corner of section 2 . The rhyolite has been intensely brecciated and veined by abundant stockwork-style pyrite and clasts are completely bleached to a white color. In a few examples, pyrite occurs as rounded 2-4 mm grains or nodules with a radiating internal texture. No sulfide other than pyrite could be identified.

Geochemistry: Four heavily altered and pyrite-veined samples were analyzed from float and outcrop in the Kushneahin Lake occurrence area (Table 3). Samples 98DC-103 to 105 are from float and outcrop in and near the main creek. Sample 98DC-107 is a high graded composite sample from outcrop at the most intensely altered outcrop described above. The geochemical signatures of all four samples are remarkably devoid of any 
anomalous metals or indicator trace elements commonly seen in mineralized systems. The samples are characterized by slight elevations of $\mathrm{Fe}, \mathrm{As},(\mathrm{Hg}$, and $\mathrm{Mo})$.

\section{St. John's Fluorite}

Location: An unnamed fluorite occurrence herein informally referred to as the St. John's fluorite occurrence is located in the center of Section 8, T. $63 \mathrm{~S}$, R. 80 E, of the Petersburg B-3 15' quadrangle. The occurrence is located in a small borrow pit on the south side of the logging road about 1.5 kilometers southeast of the boat dock in St. John Harbor on Zarembo Island. Access is by foot or vehicle by logging road from the boat dock. The borrow pit is several hundred east of the wooden bridge that crosses the creek flowing in to St. John Harbor.

Host Rocks: The borrow pit is developed predominantly in black argillite that is intruded by several basaltic dikes and sills or possibly massive flows. In the west wall of the pit a basaltic dike cuts up through the argillite and then merges into a moderately dipping twometer-thick horizon of a peculiar, highly carbonate altered rock that appears to consist of a banded, spheriulitic vitrophere. The vitrophere is of uncertain origins, possibly rhyolitic, and exhibits size grading of spheriules from its center to margins. Intense carbonate alteration is visible in the argillite for about a meter on either side of the vitrophere.

Occurrence morphology and mineralogy: The occurrence consists of veinlets and fracture surfaces that are cored and coated by fine crystalline druses of quartz and anhedral to subhedral fluorite. The quartz-fluorite veinlets are millimeters to several centimeters thick and crosscut both the igneous rocks and the argillite. Fluorite is generally semitranslucent and white, clear, or pale green in color.

Geochemistry: Six samples from the St. John's Fluorite occurrence were analyzed. Samples 93DC-02 (Table 2) and 93DC-03 (Table 1) are of unaltered argillite and basaltic dike, respectively, collected from outcrop in the west wall of the pit. Sample 93DC-05 is spheriulitic vitrophere from the two-meter-thick horizon and samples 93DC-04 and 93DC-06 are of the carbonate-altered selvages below and above the vitrophere, respectively (Table 1). Sample 93DC-07 is a representative sample of quartz-fluorite vein material (Table 3). Geochemically, the samples are unremarkable.

\section{Frenchie (St. John Harbor)}

Location: The St. John Harbor occurrence, more commonly referred to as the Frenchie occurrence (hotlink to OFR 98-784, \# PE058) consists of a conformable massive sulfide body exposed in the south bank of the creek that flows into the southwest corner of St. John Harbor on the northwest shore of Zarembo Island. The occurrence is located in the southeast quadrant of section 8, T. 63 S, R. 80 E, of the Petersburg B-3, 15' quadrangle. Access is by foot up the creek from the bridge over the logging road. Alternatively, by 
foot south from the borrow pit described above on the south side of the road in the middle of section 8 to the creek, and then upstream to the occurrence. Helicopter access can be gained by landing in the muskeg several hundred meters to the south of the occurrence and then proceeding by foot north to the creek.

The only early reference to the occurrence is a short description by Buddington (1923). He describes a tabular, east-west striking, $20^{\circ} \mathrm{S}$ dipping, pyrite body 2.3 meters thick and 40 meters long developed by a 15 meter long adit in the creek bank, and a shaft 100 meters north and above the adit. Berg and Grybeck (1980) describe a 2-m-thick pyritic layer, containing minor sphalerite, chalcopyrite, and rare galena, exposed for 75 meters and then an additional 50 meters on the downstream side of a fault that truncates the layer. Grybeck and others (1984) reported an aggregate thickness of 10 meters and a total length of 250 meters in several layers of massive sulfide. These workers interpreted the occurrence as one of the late Triassic VMS deposits in the region.

In the last decade, the occurrence has been examined repeatedly by private industry. Most recently, Westmin Resources Ltd. completed two 152-meter diamond drill holes in 1996. The first was drilled from a pad immediately over the adit on the south bank (ZAR \#1, Table 1). The second pad is located approximately 200 meters to the southeast on the west side of the small creek that flows northwards and joins the main creek approximately 125 meters upstream of the adit (ZAR \#2, Table 1). At the time of the present visit the drill core, minus the mineralized interval from ZAR \#1, had been abandoned at the site, affording an opportunity to re-log and sample the subsurface stratigraphy. The occurrence was also examined in 1993 by the present author.

Host Rocks: Outcrop in the creek consists of an immediate footwall horizon of light greenish white muscovite schist approximately 3 meters thick. This unit is in sharp contact with and is underlain by a thick sequence of slatey black argillite. Bedding at the adit appears to be dipping shallowly to the south and the footwall argillite exposed in the creek bank 100 meters upstream appears to dipping gently to the west or southwest. The hanging wall immediately above the massive sulfide lens consists of approximately one meter of a dark gray to black, quartz-veined, sulfide-rich phyllite. The quartz-rich phyllite grades upwards into a light gray to white siliceous, quartz veined muscovitechlorite phyllite to the top of the creek bank ( $\sim 10$ meters). Coarse crystalline pyrite, and minor sphalerite and galena, are present in the siliceous phyllite hanging wall and decrease in abundance rapidly with distance above the massive sulfide lens. Several 0.5 to 2-m-thick basaltic dikes of probable Tertiary-Quaternary age crosscut the creek. One of the dikes occupies a fault that truncates the massive sulfide lens approximately 75 meters downstream.

Re-logging of the drill cores indicate that the occurrence is underlain by a nearly flat-lying, 61-meter-thick mixed sequence of slatey, thin-bedded black argillite interbedded with 1-10 cm thick light green to greenish-tan, variably pyritic mafic tuff. Quartz-carbonate veining is also variable and is usually parallel to foliation. In both holes, the interval beneath the mixed argillite-tuffs consists of a chlorite-carbonate altered greenstone (meta-volcanic rock) 15-46 meters thick that is intruded by one or several similarly altered massive, blocky, gabbroic sills and is interbedded with crystal- and lapilli-tuffs. Several fresh, fine crystalline mafic dikes of presumed Tertiary-Quaternary age also are present in each hole. The interval beneath the greenstone returns to mixed 
thin-bedded argillite and mafic tuffs to the bottom of each hole. Based on the absence of any massive sulfide lenses intersected in the core and the gentle southwest dip of the argillites upstream of the adit, it would appear that ZAR \#2 was collared stratigraphically beneath the massive sulfide horizon. In drill hole ZAR \#1, the presence of increasingly sulfide-rich quartz-sericite schist to a depth of 6 meters followed by a missing interval of 6 meters, suggests that the massive sulfide interval was intersected near the top of the hole. No additional sulfide lenses or mineralized stringer veins were intersected. Several quartz-carbonate-fluorite-pyrite veins are present in the drill core at a depth of 46.5 meters (152.5 feet). The veins cross-cut altered, quartz-carbonate veined argillite and are located just above an altered, light green, mafic (?) dike about 0.5 meters thick that intrudes the sediments.

Occurrence morphology and mineralogy: At the adit the massive sulfide lens is approximately 3 meters thick and consists predominantly of coarsely recrystallized pyrite with minor chalcopyrite and sphalerite in a siliceous quartz-carbonate gangue. Along strike 50 to 100 meters upstream, the lens becomes semi-massive and then peters out into the hanging wall quartz-sericite schist. Along strike in the down creek (westerly) direction for approximately 75 meters the lens maintains its thickness. However, the massive sulfide becomes finely crystalline, more sphalerite-rich and exhibits a footwall to hanging wall zonation. Minor barite was observed in the footwall margin of the lens 46 meters west of the adit. Massive sulfide overlying the baritic exhalite is sphalerite rich. The center of the lens becomes more pyritic and then grades into more galena-rich pyritic massive sulfide towards the hanging wall. Remobilization of ductile sulfides into fractures in the immediately overlying, more brittle quartz-sericite schist has caused local chalcopyrite and galena enrichments in the hanging wall. The lens is truncated by a fault oriented N65E, 60N (Buddington, 1923) 75 meters downstream of the adit and then reappears in the north creek bank approximately 150 meters downstream of the adit. The lens is continuous downstream for approximately another 100 meters and is approximately 2 meters thick. Samples collected from the downstream end of the lens in the south bank and from the downstream end of the portion of the lens in the north bank become increasingly sphalerite-rich indicating that a proximal-distal zonation exists as well. From the adit (proximal) to the distal downstream end, the massive lens is zoned from $\mathrm{Cu}-\mathrm{Au}$ to $\mathrm{Zn}$ rich. From footwall to hanging wall the lens is zoned from $\mathrm{Zn}-\mathrm{Mn}-\mathrm{Ba}$, to $\mathrm{Fe}-\mathrm{Cu}-\mathrm{Au}$, to $\mathrm{Pb}-$ rich.

Geochemistry: The mineralogical and geochemical zonation described above is based on the collection and analysis of seven mineralized samples from the Frenchie occurrence (Table 3). Sample 93ZA-14 is pyrite-sphalerite-rich massive sulfide from the 3-m-thick lens at the adit. Sample 98ZA-01 is from the pyritic central portion of the lens 7.5 meters west of the adit. Sample 98ZA-02 is pyrite-sphalerite-rich massive sulfide from just above the footwall contact 35 meters west of the portal. Sample 98ZA-03 and -04 are a finely banded massive barite-sphalerite from near the footwall and a quartz-pyrite-galenarich, banded massive sulfide from near the hanging wall, respectively, from the south bank 46 meters west of the adit. Sample 93ZA-15 is pyrite-sphalerite-rich massive sulfide from the west end of the lens in the south bank 75 meters from the adit, and sample 93ZA-16 is similar material from the west end of the lens in the north bank 200 
meters downstream of the adit. In addition to the zonation described, the Frenchie occurrence has a geochemical signature containing $\mathrm{Fe}, \mathrm{Zn}, \mathrm{Cu}, \mathrm{Au},(\mathrm{Hg}, \mathrm{Ag}, \mathrm{As}, \mathrm{Cd}, \mathrm{Mo}$, $\mathrm{Pb}$, and $\mathrm{Sb}$ ).

Sample ZAR\#1-10 of the quartz-carbonate-fluorite-pyrite vein in drill core was also analyzed (Table 3). Interestingly, the sample is somewhat enriched in $\mathrm{Cu}, \mathrm{Au}, \mathrm{Ag}$, and As, implying the possibility of alkaline rock-related, fluorine-copper-precious metalrich mineralization on the island associated with the Tertiary-Quaternary igneous activity.

$\mathrm{An}{ }^{40} \mathrm{Ar} /{ }^{39} \mathrm{Ar}$ age determination was made on a muscovite mineral separate from a sample of the footwall muscovite schist immediately underlying the adit. The sample yielded a complicated step release spectra indicative of multiple periods of argon resetting and perturbation. The total gas age indicated is $74.2+-0.3 \mathrm{Ma}$ (C. Taylor and L. Snee, unpublished data). The pattern is interpreted as indicating complete resetting of the muscovite schist argon systematics during mid-Cretaceous followed by additional perturbations during the Tertiary.

\section{Hydropit}

Location: The Hydropit occurrence (hotlink to OFR 98-784, \# PE061), first described in Karl and others (1980), was located in a borrow pit next to a logging road in Section 27 of the Petersburg B-3, 15' quadrangle. An attempt to locate this occurrence during the present investigation was unsuccessful, raising the possibility that the occurrence has been quarried away. There are currently three borrow pits that are distributed along approximately two kilometers of the logging road. The center pit is the largest and has dimensions of $125 \times 25$ meters with a 35-meter high eastern wall. The southwesternmost pit is much smaller and has rock types similar to those described previously (Karl and others, 1980; Grybeck and others, 1984; Brew and others, 1991)

Host Rocks: Karl and others (1980) describe a hypidiomorphic granular quartz diorite cut first by a spherulitic felsic dike and then by a less deformed andesite dike. Presently, country rocks in the southwestern pit consist of a microporphyritic greenstone, probably a microgabbro or the quartz diorite, as described. Similarly, the greenstone is cut by a rhyolite dike, which in turn is cut by an undeformed mafic dike of presumed TertiaryQuaternary age.

Occurrence morphology and mineralogy: Karl and others (1980) described a 1.5-m-wide, highly altered shear zone in the greenstone containing sulfide-bearing hydrothermal veins and lenses. Sulfides present consisted of chalcopyrite, bornite, galena, sphalerite, arsenopyrite, and magnetite. Galena was also reported as disseminated in the wallrocks. No mineralization was seen in any of the three pits during the present investigation.

Geochemistry: Karl and others (1980) report data on six mineralized rocks from the Hydropit occurrence. Based on their data (flame atomic absorption and semi-quantitative DC-arc spectrography) the occurrence had a geochemical signature containing $\mathrm{Pb}, \mathrm{Cu}$, $\mathrm{Zn}, \mathrm{Ag}, \mathrm{Cd},(\mathrm{Bi}$, and Mo). Grybeck and others (1984) report enrichments of Sn and W. 


\section{Lost Zarembo}

Location: The Lost Zarembo occurrence (hotlink to OFR 98-784, \# PE062), also referred to as the Spiderman occurrence (Newberry and others, 1997), is located in a borrow pit adjacent to a logging road in the northeast corner of Section 27 of the Petersburg B-3, 15' quadrangle. The occurrence was first described by Berg and Grybeck (1980) as one of a group of Triassic VMS deposits in the area, and by Karl and others (1980). Lost Zarembo is approximately one-kilometer northeast of Hydropit and faces northwards into the prominent strike valley that bisects Zarembo Island.

Host Rocks: The occurrence is in the northwest wall of a small pit that is developed in a siliceous, quartz-sericite-chlorite phyllite that is cut by several generations of gabbro and rhyolite dikes. The greenschist is dipping shallowly under the road to the northeast.

Occurrence morphology and mineralogy: The occurrence consists of three well-defined subparallel, semi-massive sulfide lenses conformable to the foliation of the greenschist. The lower lens is approximately 1.5-2 meters-thick, has fairly sharp contacts with the wall rock, and is separated from the middle lens by approximately 2 meters of unmineralized greenschist. The middle and upper lenses are approximately $13 \mathrm{~cm}$ and 1.3-meters-thick, respectively and have similarly sharp contacts with the greenschist. Approximately 0.7 meters separate them. All three lenses are continuous along strike towards the back wall of the pit for approximately 15 meters and are truncated by a rhyolite dike. Individual samples are composed of approximately $30 \%$ sulfides in fine crystalline (tectonic) bands and as locally remobilized veinlets in siliceous bands. The sulfides are predominantly pyrrhotite with minor pyrite, sphalerite, and chalcopyrite.

Geochemistry: One sample of semi-massive, pyrrhotite-rich rock was analyzed from the Lost Zarembo occurrence (Table 3). Sample 98ZA-07 is from the best-mineralized portion of the lower lens. The geochemical signature is characterized by $\mathrm{Fe}, \mathrm{Zn}, \mathrm{Ag},(\mathrm{Cu}$, $\mathrm{Pb}, \mathrm{Au}$, and $\mathrm{Cd}$ ); consistent with analyses reported by Karl and others (1980).

\section{Bay Point U-Th-REE occurrence}

Location: An unnamed U-Th-REE occurrence here informally referred to as the Bay Point occurrence was examined and sampled during fieldwork in 1992. This occurrence is one of a number of unnamed U-Th-REE occurrences that are located between Salmon Bay and Point Colpoys on the northeastern shoreline of Prince of Wales Island (hotlink to OFR 98-784, \# PE056). The Bay Point occurrence is located in the head of the small bay in the northwest corner of section 13, T. 64 S., R. 78 E, of the Petersburg B-4, 15' quadrangle. Carbonatite veins in altered Silurian metasediments and blocky basalt flows are exposed in beach outcrops and are easily accessible by boat. Grybeck and Berg (1998) report that numerous claims were staked in the area in the early 1950's and provide extensive additional references. 
Host Rocks: Country rock at the Bay Point occurrence consists of Silurian graywacke overlain (?) along the north shore of the bay by blocky, altered basalt flows. At least one basaltic dike intrudes the basalt flows on the north shore of the bay.

Occurrence morphology and mineralogy: In 1992 a traverse was made through the bay from the southern shore to the northern shore. The relationships observed are described below. Country rock on the southern shore of the bay, consisting of distal, siliceous metaturbidites, are cut by orange-altered, radioactive carbonatite veins with moderate sulfides. Sample 92ZA-04 is a sulfide-bearing carbonatite vein as described above. On the west shore of the bay, a series of distal turbidites are offset or intruded by a carbonatite unit that is oriented N40W, 70NE and is about 2.5 meters wide. The unit is characterized by black, fine crystalline carbonate that is pervasively altered and veined by an iron-rich, dark brown to orange carbonate. Stringer veins of orange carbonate extend outward into the metaturbidites. 92ZA-05 is a sample of the metaturbidite host rock collected about 2 meters from the margin if the black carbonate. 92ZA-06 is a sample of the black, fine-grained carbonate rock with minor orange carbonate veining.

The black carbonate unit and the orange carbonate alteration are not as radioactive as the veins on the southern shore. Field relationships suggest that a fault cuts the metaturbidites and has served as a conduit for carbonatite fluid alteration. The black carbonate is against the footwall of the structure and is possibly a carbonate altered metaturbidite or a carbonatite dike. To the northeast of the fault contact, the metaturbidite is fresher and more silicic, scratches with difficulty and does not fizz in acid. The metaturbidite contains minor carbonate veining that is mostly conformable with bedding. Outcrop to the southwest of the fault consists of a heavily altered, veined, and brecciated footwall sequence of turbidites. Blocks within the footwall breccia have a banded appearance like the unaltered turbidite sequence to the northeast. Examination of air photos suggests that this structure extends through Salmon Bay to the south (J. Philpotts and C. Taylor, unpublished data). Sample 92ZA-07 is from another highly altered outcrop of metaturbidites and black carbonate down the beach another 70-90 meters to the northwest.

Outcrop in the northwest corner of the bay consist of more carbonate-altered exposures of very reddish-orange rock that has very few included clasts of metaturbidites. Clasts are matrix supported and are 1-3 $\mathrm{cm}$ in size, with occasional clasts up to 20 centimeters, in a matrix of orange carbonate (sample 92ZA-08). Carbonate alteration becomes more pervasive from one end of the beach to the other, possibly indicating a more carbonate-rich portion of a carbonatite complex. Immediately to the north, outcrop of the metaturbidite becomes less altered.

On the north side of the bay, outcrop consists of very blocky basaltic volcanic rocks (sample 92ZA-09) with xenoliths of white carbonate or marble (92ZA-10). The volcanic rocks are cut by a white carbonate vein (sample 92ZA-11), 10-15 centimeters wide, which is in turn intruded by a 0.6-meter thick basaltic dike (sample 92ZA-13) that comes up in between layers of the white carbonate vein. The vein carbonate contains banded layers of sphalerite and galena oriented parallel to the vein margins. There is about a 2.5 -centimeter thick reaction rim on the inside of the white carbonate veins between the carbonate and the intrusive basalt. This orange carbonate reaction rim (sample 92ZA-12) is symmetrical on the inner side of the white carbonate veins at the contact with the basaltic dike. No reaction rim occurs on the outer contact of the white veins with the basalt flow country rock. The 
attitude of the basalt flows is roughly conformable with the metaturbidites in the head of the bay. The white carbonate veins and the basaltic dike sharply cross cut the basalt flows.

Field relationships at the Bay Point occurrence are consistent with a sequence of events initiated by extrusion of the blocky volcanic rocks on to the metaturbidites. The white xenoliths of carbonate probably represent interflow carbonate layers that have been ripped up during extrusion and incorporated into the overlying flows. Alteration and carbonate veining resulting in emplacement of U-Th-REE enriched minerals and associated sulfides, occurred during emplacement of carbonatite along the northwest trending structure(s). Intrusion of basaltic dikes further remobilized the carbonate to produce the reddish-orange, $\mathrm{Fe}$ - and $\mathrm{Mg}$-rich carbonate alteration that occurs throughout the bay and radiates into the basaltic flow rocks.

Geochemistry: Ten samples were collected and analyzed from the Bay Point occurrence all of which were variably altered, carbonatite-bearing, or contained visible sulfides (Table 3). $\mathrm{Pb}$ and/or $\mathrm{Zn}$ enrichments characterize samples with visible sulfides.

Carbonatite-bearing samples are characterized by elevated values of $\mathrm{Ce}, \mathrm{La}, \mathrm{Mn}, \mathrm{Sr}, \mathrm{Nb}$, $\mathrm{Nd}$, and $\mathrm{Y}$.

\section{Round Point}

Location: The Round Point occurrence (hotlink to OFR 98-784, \# PE063), first described by Grybeck and others (1984), is located in the bed of a small creek flowing southeasterly through section 36 of the Petersburg B-3, 15' quadrangle. The occurrence is at an elevation of 464 meters near the lower end of a relatively flat topographic bench southeast of a small lake. The creek steepens sharply, immediately downstream of the occurrence.

Host Rocks: Country rock at the Round Point occurrence consists of a highly foliated, light gray to tan colored, variably quartz-sericite-chlorite-pyrite-rich schist with abundant reddish-orange areas of alteration and weathering. Foliation is oriented N40W, 10S and is cut by a pervasive meter-spaced jointing oriented N27E. A dark green, meter-wide, porphyritic-aphanitic basaltic dike exploits such a joint approximately 10 meters south of the occurrence. Grybeck and others (1980) report interbeds of light gray silicified limestone and dark gray argillite.

Occurrence morphology and mineralogy: The occurrence consists of a $0.3 \mathrm{~m}$-thick lens of semi-massive sulfide, conformable to foliation that crosses the creek and is exposed in the face of a meter-high ledge. The lens is continuous across the 4-meter-width of the creek. The lens is banded and contains $10-20 \%$ sulfides, primarily pyrite with lesser chalcopyrite and sphalerite. The sulfides are fine crystalline and are disseminated and distributed as whisps in siliceous, muscovite schist. Sphalerite is locally concentrated into several 2-3 mm-thick seams and is slightly more coarse crystalline and is dark reddish brown in color. 
Geochemistry: One mineralized rock sample was analyzed from the 0.3 -m-thick semimassive lens (Table 3). Sample 98ZA-09 has a geochemical signature characterized by $\mathrm{Fe}, \mathrm{Zn}, \mathrm{Cu}, \mathrm{Ag}, \mathrm{Cd},(\mathrm{Au}, \mathrm{Hg}, \mathrm{Sb}, \mathrm{Bi}$, and $\mathrm{Mo}$ ), and contains $2.0 \% \mathrm{Zn}$.

\section{Snow Passage Fluorite}

Location: The Snow Passage Fluorite occurrence (hotlink to OFR 98-784, \# PE060) is located in the tide zone on the southwestern shore of Zarembo Island due east of the northern tip of Brushy Island. Buddington (1923) described numerous "narrow breccia zones and seams" in the Tertiary volcanic rocks that comprise this entire shoreline and noted that they commonly contain open space coated with chalcedonic quartz and fine crystalline druzes of quartz. Less commonly, they contain a paragenetically later coating or filling of clear to pale green fluorite as best exemplified by the Snow Passage occurrence.

Host Rocks: Country rock all along the southwest shore of Zarembo Island is a TertiaryQuaternary volcanic series of massive to volcaniclastic andesites and rhyolites. Current mapping (Karl and others, this study) suggests the rocks in the vicinity of the occurrence consist of flow banded rhyolite and rhyolite tuffs. Within the approximately 100 -meterwide portion of the tide zone that is fluorite mineralized, the rhyolite is variably chloritic and locally silicified.

Occurrence morphology and mineralogy: Clear to pale green and minor purple, massive to euhedral fluorite occurs as matrix in brecciated rhyolite and as the youngest filling in $\mathrm{mm}$ to 5 -cm-thick quartz-fluorite veins. Buddington (1923) describes a single breccia zone that ranges in width from $2 \mathrm{~cm}$ to one meter with quartz-fluorite coated rhyolite clasts up to 0.3 meters in size. The clasts generally have a thin coating of silica upon which a layer of fluorite $1-5 \mathrm{~cm}$ is deposited. Grybeck and others (1984) noted fluorite over a 100-meter-area and described vuggy, fluorite-coated fractures. Consistent with previous descriptions, this author noted the presence of the fluorite-cemented breccia and several discontinuous quartz-fluorite veins. The presence of pyrite impregnated in the wallrock selvages and the lack of any geochemical data on the fluorite veins prompted the current geochemical analysis in order to check for epithermal, alkaline-Au type mineralization associated with the Tertiary-Quaternary volcanism.

Geochemistry: Sample 98ZA-16 is a pyrite-rich, 2.5 -cm-thick quartz-fluorite vein sample from one of the more persistent veins at the Snow Passage Fluorite occurrence (Table 3). The sample has a geochemical signature characterized by low abundances of $\mathrm{Fe}, \mathrm{As},(\mathrm{Au}$, and $\mathrm{Mo})$.

\section{SE Zarembo Siliceous (Vent?) Breccia}

Location: An unusual occurrence of a pervasively silicified breccia of unknown origin is located in the mouth of the creek that drains onto the southeast shore of Zarembo Island 
from the drainage that hosts the Round Point occurrence. The occurrence is at the south edge of section 31 of the Petersburg B-3, 15' quadrangle approximately one kilometer southwest of Round Point. The occurrence has been mapped by Brew (1997b) as a vent breccia.

Host Rocks: Country rock into which the breccia is emplaced is a highly foliated and isoclinally folded sequence of greenschist and meta-sediments, mapped during this study as a Triassic volcano-sedimentary sequence (Karl and others, this study). A Tertiary alkaline granite outcrops along the shoreline to the northeast.

Occurrence morphology and mineralogy: The silicified breccia was observed in outcrop only within a relatively restricted diameter of approximately 75 meters in the bed and banks of the creek. Continuation or additional occurrences up the creek or southwest along the shoreline could not be proved. The breccia consists of angular to subangular clasts $5 \mathrm{~mm}$ to $15 \mathrm{~cm}$ in size (Brew, 1997b) of thoroughly silicified light gray to tan volcanic rocks, alkaline granite and other rock fragments so silicified as to preclude identification of a precursor. The breccia is clast supported and has a matrix of both chalcedonic silica and unidirectional, isopachous rinds of clear to white, subhedral to euhedral quartz. Rare pyrite is present as individual, sub-millimeter-sized grains.

Geochemistry: One sample, 98ZA-13, of the siliceous breccia was analyzed (Table 3). Geochemically, the rock is, with the exception of one element, unremarkable and has very low metal abundances. The geochemical signature is characterized by $\mathrm{Li},(\mathrm{Au}, \mathrm{Ag}$, $\mathrm{Mo}$, and Sb). The elevated concentration of $206 \mathrm{ppm}$ lithium, five times the Clarke value for average granite, is unusual. Lithium is a commonly enriched element in pegmatites, a volatile-rich stage related to late crystallization of granites. It is possible that the lithium enrichment is indicative of a late stage evolution and volatile release produced during late stage crystallization of the Tertiary alkaline granite that outcrops in association with the siliceous breccia.

\section{DISCUSSION AND SUGGESTIONS FOR PROSPECTING}

Review of the characteristics of the occurrences described above (Table 4) demonstrates that there are a wide variety of deposit types present in the study area. In a broad sense these deposits are divisible into three groups based upon their probable age and corresponding metallogenic environment. The oldest and by far the largest group of occurrences examined are included in the belt of Late Triassic mines, prospects, and occurrences that has been described in some detail earlier in this paper. Fifteen of the twenty five occurrences examined during this study fall into this group and are variably described as having features similar to VMS, Sedex, bedded barite, syndiagenetic replacement, and epigenetic carbonate-replacement type deposits (see Cox and Singer, 1986). The age of host rocks for this group ranges in age from Late Triassic to possibly as old as Devonian. However, in all cases where age constraints are available, the age of mineral formation is Late Triassic. The second group consists of occurrences of probable Cretaceous age that are linked by the combined processes of regional metamorphism and subduction-related intrusive activity resulting from the accretion of the Wrangellia 
composite terrane to the continental margin. Deposit types represented include skarns (Northern Copper), magmato-hydrothermal veins (Hydropit), and metamorphic veins (Coonrod's Zinc and Maid of Mexico). The third group of occurrences is generally related to a series of extrusive and intrusive igneous events of Tertiary and Quaternary age. This group includes the possibly porphyry-related high sulfidation epithermal system at Kushneahin Lake, the peridot-bearing diatreme at Indian Point Peridot, the vein fluorite occurrences at St. John's Fluorite, Frenchie, and Snow Passage Fluorite, and the vent breccia at SE Zarembo Siliceous Breccia. The age and association of the Bay Point U-Th-REE occurrence is uncertain. It may be related to the Jurassic alkaline igneous events that were responsible for somewhat similar deposits at Bokan Mountain and Dora Lake on Prince of Wales Island (Philpotts and others, 1993; 1996; 1998; Barker and Mardock, 1990), or to U-Th-REE enrichments associated with Tertiary-Quaternary volcanic activity in the Snow passage area of Zarembo Island just $10 \mathrm{~km}$ to the east (Philpotts and Evans, 1992).

Consistent with the primary goal of the airborne geophysical survey, of aiding exploration for Greens Creek-like deposits, it is worth considering the occurrences of the Late Triassic group in further detail. One of the more notable features of this group, despite their similar host rock age and geochemical signatures (Table 4), is the remarkable variety of morphologies they exhibit. The Late Triassic mineral belt in southeastern Alaska is commonly referred to as a VMS belt (Berg and Grybeck, 1980; Berg, 1981; Newberry and others, 1997; Taylor, 1997; Taylor and others, 1995a and b; 1999a; 2000a). However, inspection of Table 4 reveals that in the current study area, comprising the central portion of the mineral belt, only a few of the fifteen Late Triassic "VMS" occurrences listed in Table 4 are actually stratiform massive sulfides that bear a resemblance to currently accepted models of the deposit type. The Frenchie deposit on Zarembo Island is perhaps the best example of a stratiform, lens-shaped, massive sulfide body associated with Late Triassic volcanics that probably was formed by exhalative fluids on or very near the paleoseafloor. Many of the smaller occurrences in the study area are stratiform and clearly volcanic-hosted, but do not form massive lenses. Rather they are stratiform accumulations of disseminated, semi-massive, and often vein-like or banded sulfides in greenstones such as the Towers Peninsula, Lost Show, Harvey Lake East, Harvey Lake South, Butterworth Island, Lost Zarembo, and Round Point occurrences. The Brushy Creek occurrence, hosted entirely within mafic volcanic rocks, is clearly epigenetic in its morphology and may represent a VMS feeder zone without an overlying stratiform massive sulfide body. The Helen-S occurrence is a stratabound accumulation of sulfide-bearing veins and disseminations in and adjacent to a shallowly emplaced mafic sill of probable Late Triassic age. The similarity of the geochemical signature to other deposits in the Late Triassic belt, the presence of the small massive sulfide lens, and the relationship to a hypabyssal mafic intrusive body are all features that link the occurrence to the mineral belt. The Helen-S occurrence represents one of the better examples of the importance of co-evolutionary hypabyssal mafic-ultramafic sills and dikes to the formation of Greens Creek-like Late Triassic mineral deposits (Taylor and others, 1999a).

Still other occurrences in the study area are included in the group of late Triassic "VMS" deposits that bear little resemblance to the standard deposit models. The Taylor Creek and Wetboot occurrences are perhaps the most interesting and provide critical 
insights into the variety of processes responsible for the formation of deposits within the Late Triassic belt. Both occurrences contain stratabound horizons of nodular pyrite and botryoidal sulfide crusts in limestone layers that arguably formed during sedimentation and early diagenesis of the host rock. Late Triassic conodonts recovered from the limestones in Taylor Creek and the hallmark Greens Creek-like geochemical signatures at both occurrences firmly place them within the Late Triassic group of deposits despite their lack of VMS characteristics. Formation of massive sulfide bodies in sedimentary rocks during sedimentation and diagenesis is more generally a feature of massive sulfide deposits of the Sedex-type. Similarly, the Junior Creek occurrence is entirely hosted within black shales (of Triassic age) and thus may more properly be compared to a Sedex deposit. Additionally, at Taylor Creek, all of the previously recognized outcrops of mineralized rock are clearly epigenetic accumulations of sulfides that formed as veins and breccia matrix in limestone, and as disseminated and semi-massive replacements of limestone. These characteristics are more similar to features described in the carbonatehosted mineral deposits of the Irish Midlands, a class of deposits that exhibits features of both epigenetic and syngenetic mineral formation (Hitzman and Beaty, 1996).

If all of these occurrences are linked by a causal relationship and formed within a relatively brief period in the Late Triassic as it appears, why is there such diversity in their morphological expression? Why are there syngenetic, diagenetic and epigenetic examples of mineral formation within a spatially and temporally related group of occurrences? The interpretation preferred by this author is that such diversity is the natural result of their formation within an evolving tectonic setting. As previously described in this paper and elsewhere (Taylor and others, 1995a and b; Taylor, 1997; Taylor and others, 1999a and b; Taylor and others, 2000a and b), the Late Triassic mineral belt in southeastern Alaska is thought to be a product of formation within a propagating intra-arc rift. The current study area is coincident with the central portion of this propagating rift environment where subaerial and shallow water, near-arc stratigraphic settings are giving way to subaqueous, deeper water, distal-to-the-arc settings. Features of the host rocks at occurrences in the study area are consistent with a highly tectonically active position at and just outboard of the Late Triassic rift margin. Thin horizons of polymictic conglomerate near the base of the Triassic section giving way to basinal (pyritic, graphitic) black shales, and the early formation and later foundering of thin carbonate platform rocks attests to the active rifting and rapid subsidence of restricted sub-basins in the area. The presence of primitive volcanic rocks that exhibit less arc-contamination than equivalent volcanic rocks in the southern end of the belt and the association with hypabyssal intrusive rocks that were emplaced at shallow levels in the rift during thinning of the crust are all consistent with a deepening arc-shelf to arc-slope position within the evolving rift.

The variation in the nature of the occurrences suggests that hydrothermal fluid circulation occurred in different stratigraphic settings and at slightly different times during the evolution of the rift. The presence of semi-massive sulfide in the conglomerates near the base of the section indicate that hydrothermal fluids were present in, or at least traveled through, the conglomerates in early stages of rifting, and stockwork as well as stratiform sulfides in the volcanic rocks indicate that mineral formation occurred during and after extrusion. The formation of base metal-rich diagenetic pyrite in limestones suggests that hydrothermal fluids were circulating at the time of 
sedimentation and lithification of the limestones during an early, shallow water portion of the Late Triassic. Epigenetic sulfides as limestone replacements and in breccias at Taylor Creek are the result of mineral formation after foundering and brecciation of the limestone platform later in the rift history. The presence of stratiform massive sulfide bodies enclosed primarily in basinal shales indicates that mineral formation occurred during later periods of quiescence in more distal settings. As a result, the mineral occurrences in this transitional region of the mineral belt exhibit characteristics of a full spectrum of deposit types, all of which are linked by their formation in an evolving rift environment.

The Castle Island Barite deposit is the one in the study area that shares the most characteristics with the Greens Creek deposit. Additionally, it also may serve to illustrate why deposits in the study area do not have as high a potential to develop into economic mines as deposits in the northern portion of the mineral belt. Like Greens Creek, the Castle Island Barite deposit occurs near a contact between footwall mafic volcanic rocks and overlying sediments, and is associated with a footwall alteration zone characterized by quartz-sericite-carbonate-sulfide mineralogy. Although Castle Island was primarily a barite deposit it contained a sulfide-sulfosalt mineral assemblage very similar to the early barite-rich ore facies at Greens Creek and shares a nearly identical geochemical signature characterized by major $\mathrm{Ba}-\mathrm{Zn}-\mathrm{Pb}-\mathrm{Ag}$ and highlighted by an Sb-rich trace metal assemblage containing $\mathrm{Hg}-\mathrm{Cd}-\mathrm{As}-\mathrm{Mo}$ and $\mathrm{Cu}-\mathrm{Au}-\mathrm{Mn}$. The only marked geochemical difference between Greens Creek and Castle Island is the marked absence of an ultramafic-related suite of elements at the latter, however enrichments of $\mathrm{Co}-\mathrm{Cr}-\mathrm{Ni}$ are noted in the stringer zone beneath the deposit. Similar to the early ore forming history at Greens Creek, this author suggests that Castle Island Barite deposit began forming relatively early during the Late Triassic rift after an initial period of mafic volcanism but before significant subsidence or accumulation of sediments had occurred. Formation of silver-rich, barite-carbonate-silica-sulfide ores began at low temperature in a shallow, sub-aqueous setting either at or close to the paleo seafloor by mixing of a reduced, barium rich, and base metal poor hydrothermal fluid with oxygenated seawater. As rifting intensified the Castle Island system was gradually buried by an influx of turbidites into the deepening rift.

Compared to Greens Creek several critical factors for the development of an economic massive sulfide failed to develop. Most notably, the Castle Island deposit did not develop anoxic bottom-water conditions leading to the development of a reducing shale cap. At Greens Creek this feature is thought to have served as an insulating blanket resulting in higher hydrothermal temperatures as well as a physiochemical trap in which ascending metal-rich fluids mixed with biogenically reduced sulfur. The Castle Island Barite deposit failed to attain restricted bottom-water conditions conducive to the formation of a biogenic sulfur-rich shale cap and thus never reached the higher temperatures or the sustained reduced sulfur supply necessary to form significant quantities of massive sulfide. The Castle Island Barite deposit does exhibit characteristics transitional between VMS and Sedex deposits and, like Greens Creek and some of the other deposits in the current study area, may represent a hybrid type of deposit (Taylor and others, 1999b).

Based upon the descriptions and discussion presented above the following exploration guidelines for Greens Creek-like polymetallic massive sulfide deposits in 
southeastern Alaska are suggested: 1) restrict exploration to Late Triassic volcanosedimentary host sequences exhibiting evidence of succession from tectonic activity to quiescence (such as conglomeratic and/or mafic volcaniclastics or flows overlain by platform carbonate or shale sequences), 2) select targets where geophysical and other data indicates the presence or suggests proximity to Late Triassic mafic-ultramafic intrusions, 3) look for evidence of quartz-carbonate-fuchsite altered ultramafic bodies, 4) favor large accumulations of pyritic, graphitic shales, 5) look for the presence of barite and/or iron-manganese-rich carbonates, 6) look for low-iron sphalerite and antimony-rich sulfosalt minerals in vein or massive sulfide assemblages, 7) examine mineralized rock and other types of reconnaissance geochemical data sets for a geochemical signature including $\mathrm{Fe}-\mathrm{Zn}-\mathrm{Pb}-\mathrm{Cu}-\mathrm{Ag}-\mathrm{Au}-\mathrm{Sb}-\mathrm{Hg}-\mathrm{As}-\mathrm{Cd}-\mathrm{Ba}-\mathrm{Mn}-\mathrm{Mo}-\mathrm{Tl}$ and the ultramafic-related suite of elements $\mathrm{Ni}-\mathrm{Cr}-\mathrm{Co}$, and 8 ) favor a geophysical signature characterized by the coincidence of a sharp resistivity contrast with evidence for buried intrusive rocks. Critical factors for the development of larger, economic orebodies are significant thickness of pyritic, graphitic shale indicating that a locally reducing sedimentary setting was established and that accumulation of an insulating shale blank occurred, and proximity to Late Triassic aged hypabyssal mafic-ultramafic intrusive rocks.

\section{ACKNOWLEDGEMENTS}

Excellent reviews by Jane Hammarstrom, Rick Saltus, and Sue Karl significantly improved this paper. During the summer 1998 fieldwork, Mike Coonrod was a constant source of valuable local knowledge and history of prospects in the study area and provided excellent helicopter support. Captain Rick Mathews of the MV Barbara Kay is thanked for his logistical support. Fieldwork during the summers of 1992 and 1993 was ably supported by Captain Gary McWilliams, MV Hyak, who also gave generously of his extensive local knowledge of mines and mineral prospects in the area. Peter Haeussler and Sue Karl are thanked for permission to include their descriptions and data for their rocks, represented in Table 1. Discussions in the field with John Philpotts and Steve Smith helped develop and refine the ideas presented in this paper. 


\section{REFERENCES}

Amoco Minerals Company, 1979, Behm Canal Project D-77-37, geology and geophysics map (unpublished), scale 1:24,000.

Barker, J.C., and Mardock, Cheryl, 1990, Rare-earth-element and yttrium-bearing pegmatite dikes near Dora Bay, southern Prince of Wales Island: U.S. Bureau of Mines Open File Report 19-90, 41 p.

Bazard, D.R., Butler, R., Gehrels, G., and Soja, C.M., 1994, New constraints for Late Silurian-Devonian paleogeography of the Alexander terrane, southeastern Alaska: Geological Society of America Abstracts v. 26, p. A384.

Berg, H.C., 1981, Upper Triassic volcanogenic massive-sulfide metallogenic province identified in southeastern Alaska: U. S. Geological Survey Circular 823-B, pp. B104-B108.

Berg, H.C., Jones, D.L., and Richter, D.H., 1972, Gravina-Nutzotin belt: Tectonic significance of an upper Mesozoic sedimentary and volcanic sequence in southern and southeastern Alaska: U. S. Geological Survey Professional Paper 800-D, p. D1D24.

Berg, H.C., Jones, D.L., and Coney, P.J., 1978, Map showing pre-Cenozoic tectonostratigraphic terranes of southeastern Alaska and adjacent areas: U.S. Geological Survey Open-File Report 78-1085, 2 sheets, scale 1:1,000,000.

Berg, H.C., and Cobb, E.H., 1967, Metalliferous lode deposits of Alaska: U. S. Geological Survey Bulletin 1246, 254 p.

Berg, H.C., and Grybeck, Donald, 1980, Upper Triassic volcanogenic Zn-Pb-Ag-(Cu$\mathrm{Au}$ )-barite mineral deposits near Petersburg, Alaska: U. S. Geological Survey Open File Report 80-527, 9 p.

Brew D.A., 1997a, Reconnaissance geologic map of the Petersburg C-4 quadrangle, southeastern Alaska: U. S. Geological Survey Open File Report 97-156-J, 21 p., 1 sheet, scale 1:63,360.

Brew D.A., 1997b, Reconnaissance geologic map of the Petersburg B-3 quadrangle, southeastern Alaska: U. S. Geological Survey Open File Report 97-156-E, 24 p., 1 sheet, scale $1: 63,360$.

Brew, D.A., Drew, L.J., Schmidt, J.M, Root, D.H., and Huber, D.F., 1991, Undiscovered locatable mineral resources of the Tongass National Forest and adjacent lands, southeastern Alaska: U. S. Geological Survey Open File Report 91-10, 370 p., 11 figs., 16 sheets, scale 1:250,000 and 1:500,000. 
Brew, D.A., and Ford, A.B., 1984, Tectonostratigraphic terranes in the Coast plutonicmetamorphic complex, southeastern Alaska: in Bartsch-Winkler, S., and Reed, K.M., eds., the United States Geological Survey in Alaska; Accomplishments during 1982: U.S. Geological Survey Circular 939, p. 90-93.

Buddington, A.F., 1923, Mineral deposits of the Wrangell district: U. S. Geological Survey Bulletin 739, pp. 51-75.

Buddington, A.F., and Chapin, Theodore, 1929, Geology and mineral deposits of southeastern Alaska: U. S. Geological Survey Bulletin 800, 398 p.

Burchard, E.F., 1914, A barite deposit near Wrangell: U. S. Geological Survey Bulletin 592, pp. 109-117.

Chapin, Theodore, 1918, Mining developments in the Ketchikan and Wrangell mining districts: U. S. Geological Survey Bulletin 662, pp. 63-75.

Churkin, M., Jr., and Eberlein, G.D., 1977, Ancient borderland terranes of the North American Cordillera; correlation and microplate tectonics: Geological Society of America Bulletin, v. 88, p. 769-786.

Cobb, E.H., 1972, Metallic mineral resources map of the Petersburg quadrangle, Alaska: U. S. Geological Survey Miscellaneous Field Studies Map MF-415, 1 sheet, scale $1: 250,000$.

Cobb, E.H., 1978, Summary of references to mineral occurrences (other than mineral fuels and construction materials) in the Petersburg quadrangle, Alaska: U. S. Geological Survey Open File Report 78-870.

Cox, D.P., and Singer, D.A., eds., 1986, Mineral Deposit Models: U.S. Geological Survey Bulletin 1693, $379 \mathrm{p}$.

Engebretson, D.C., Cox, A., and Gordon, R.G., 1985, Relative motions between oceanic and continental plates in the Pacific basin: Geological Society of America Special Paper 206, 59 p.

Forbes, R.B., Gilbert, Wyatt, and Redman, Earl, 1989, Geologic setting and petrology of the metavolcanic rocks in the northwestern part of the Skagway B-4 quadrangle, southeastern Alaska: Alaska Division of Geological and Geophysical Surveys and U.S. Bureau of Mines Public-data File 89-14, 43 p.

Ford, A.B., and Brew, D.A., 1988, Major-element geochemistry of metabasalts of the Juneau-Haines region, southeastern Alaska: in Galloway, J.P., and Hamilton, T.D., eds., Geologic studies in Alaska by the U.S. Geological Survey during 1987: U.S. Geological Survey Circular 1016, p. 164-168. 
Ford, A.B., and Brew, D.A., 1993, Geochemical character of Upper Paleozoic and Triassic greenstone and related metavolcanic rocks of the Wrangellia terrane in northern southeastern Alaska: in Dusel-Bacon, C., and Till, A.B., eds., Geologic studies in Alaska by the U.S. Geological Survey, 1992: U.S. Geological Survey Bulletin 2068, pp. 197-217.

Gehrels, G.E., and Saleeby, J.B., 1987a, Geology of southern Prince of Wales Island, southeastern Alaska: Geological Society of America Bulletin, v. 98, p. 123-137.

Gehrels, G.E., and Saleeby, J.B., 1987b, Geologic framework, tectonic evolution, and displacement history of the Alexander terrane: Tectonics, v. 6, pp. 151-173.

Gehrels, G.E., and Berg, H.C., 1994, Geology of southeastern Alaska: in Plafker, George and Berg, H.C., (eds.) The geology of Alaska, v. G1, pp. 451-468.

Gehrels, G.E., Dodds, C.J. and Campbell, R.B., 1986, Upper Triassic rocks of the Alexander terrane, SE Alaska, and the Saint Elias Mountains of B.C. and Yukon: Geological Society of America Abstracts with Programs, v. 18, p. 109.

Gehrels, G.E., Dickinson, W.R., Ross, G.M., Stewart, J.H., and Howell, D.G., 1994, Provenance of detrital zircons in strata of the cordilleran miogeocline and selected outboard terranes: Geological Society of America Abstracts v. 26, p. A384.

Gehrels, G.E., Saleeby, J.B., and Berg, H.C., 1987, Geology of Annette, Gravina, and Duke Islands, southeastern Alaska: Canadian Journal of Earth Sciences, v. 24, p. 866-881.

Goldfarb, R.J., 1997, Metallogenic evolution of Alaska: in Goldfarb, R.J., and Miller, L.E., (eds.) Mineral deposits of Alaska, Economic Geology Monograph 9, pp. 434.

Goldfarb, R.J., Miller, L.D., Leach, D.L., and Snee, L.W., 1997, Gold deposits in metamorphic rocks of Alaska: in Goldfarb, R.J., and Miller, L.E., (eds.) Mineral deposits of Alaska, Economic Geology Monograph 9, pp. 151-190.

Grybeck, D.J., Berg, H.C., and Karl, S.M., 1984, Map and description of the mineral deposits in the Petersburg and eastern Port Alexander quadrangles, southeastern Alaska: U. S. Geological Survey Open File Report 84-837, 87 p., 1 sheet, scale $1: 250,000$.

Grybeck, D.J., and Berg, H.C., 1998, Alaska Resource Data File - Petersburg Quadrangle: U. S. Geological Survey Open File Report 98-784, 176 p.

Haeussler, P.J., Coe, R.S., and Onstott, T.C., 1992, Paleomagnetism of the Late Triassic Hound Island Volcanics: Revisited: Journal of Geophysical Research, v. 97, p. 19,617-19,939. 
Haeussler, P.J., Karl, S.M., Mortensen, J.K., Layer, Paul, and Himmelberg, G.R., 1999, Permian and mid-Cretaceous deformation of the Alexander terrane on Admiralty and Kupreanof Islands, southeastern Alaska: Geological Society of America Abstracts with Programs v. 31, no. 6, p. A-60.

Hillhouse, J.W., 1987, Accretion of southern Alaska: in Kent, D.V., and Krs, M., (eds.) Laurasian paleomagnetism and tectonics: Tectonophysics, v. 139, pp. 107-122.

Hillhouse, J.W., and Gromme, C.S., 1984, Northward displacement and accretion of Wrangellia; New paleomagnetic evidence from Alaska: Journal of Geophysical Research, v. 89, pp. 4461-4477.

Hitzman, M.W., and Beaty, D.W., 1996, The Irish Zn-Pb-(Ba) orefield: in Sangster, D.F., ed., Carbonate-hosted Lead-Zinc Deposits, $75^{\text {th }}$ Anniversary Volume, Society of Economic Geologists Special Publication Number 4, p. 112-143.

Karl, S.M., 1993a, The geology of Annette Island: in Godwin, L.H., and Smith, B.D., eds., Northwest Mining Association Special Symposium 1993 on economic mineral resources of the Annette Islands Reserve, Alaska, pp. 21-26.

Karl, S.M., 1993b, Triassic volcanic and sedimentary rocks, Annette Island, southeastern Alaska: Alaska Miners Association Conference Juneau Abstracts of Professional Papers, p. 37.

Karl, S.M., Berg, H.C., Grybeck, D., and Abramson, B.S., 1980 Tables describing metalliferous and selected nonmetalliferous mineral deposits in the Petersburg and eastern Port Alexander quadrangles, Alaska; U. S. Geological Survey Open File Report 80-793, 14 p., 4 sheets, scale 1:250,000.

Karl, S.M., Haeussler, P.J., and McCafferty, Anne, 1999, Reconnaissance Geologic Map of the Duncan Canal/Zarembo Island area, southeastern Alaska: U.S. Geological Survey Open File Report 99-168.

Kerns, W.H., 1950, Investigation of Taylor Creek lead-zinc deposit, Kupreanof Island, Petersburg, Alaska: U. S. Bureau of Mines Report of Investigations 4669, 13 p.

MacIntyre, D.G., 1986, The geochemistry of basalts hosting massive sulfide deposits, Alexander terrane northwest British Columbia: British Columbia Ministry of Energy, Mines, and Petroleum Resources, Geological Fieldwork, 1985, Paper 1986-1, pp. 197-210.

MacIntyre, D.G., and Schroeter, T.G., 1985, Mineral occurrences in the Mount Henry Clay area: British Columbia Ministry of Energy, Mines, and Petroleum Resources, Geological Fieldwork, 1984, Paper 1985-1, pp. 365-379. 
McClelland, W.C., and Gehrels, G.E., 1990, Geology of the Duncan Canal shear zone: Evidence for Early to Middle Jurassic deformation of the Alexander terrane, southeastern Alaska: Geological Society of America Bulletin, v. 102, pp. 13781392.

Newberry, R. J., and Brew, D.A., 1997, The Upper Triassic Greens Creek VMS (Volcanogenic Massive Sulfide) deposit and Woewodski Island VMS prospects, southeastern Alaska: Chemical and isotopic data for rocks and ores demonstrate similarity of these deposits and their host rocks: U.S. Geological Survey Open File Report 97-539, 49 p.

Newberry, R. J., and Brew, D.A., 1999, Chemical and isotopic data for rocks and ores from the Upper Triassic Greens Creek and Woewodski Island volcanogenic massive sulfide deposits, southeastern Alaska: in Kelley, K.D., ed., Geologic studies in Alaska by the U.S. Geological Survey, 1997: U.S. Geological Survey Professional Paper 1614, pp. 35-55.

Newberry, R. J., Crafford, T.C., Newkirk, S.R., Young, L.E., Nelson, S.W., and Duke, N.A., 1997, Volcanogenic massive sulfide deposits of Alaska: in Goldfarb, R.J., and Miller, L.E., (eds.) Mineral deposits of Alaska, Economic Geology Monograph 9, pp. 120-150.

Peter, J.M., and Scott, S.D., 1999, Windy Craggy, northwestern British Columbia: The World's largest Besshi-type deposit: in Barrie, C.T., and Hannington, M.D., eds., Vocanic-associated massive sulfide deposits: Processes and examples in modern and ancient settings, Society of Economic Geologists Reviews in Economic Geology, v. 8, pp. 261-295.

Philpotts, J., and Evans, J.A., 1992, Rare earth minerals in "Thunder Eggs" from Zarembo Island, southeast Alaska: in Bradley, D.C., and Dusel-Bacon, C., eds., Geologic Studies in Alaska by the U.S. Geological Survey, 1991: U.S. Geological Survey Bulletin 2041, p. 98-105.

Philpotts, J., Taylor, C., Evans, J., and Emsbo, P., 1993, Newly discovered molybdenite occurrences at Dora Bay, Prince of Wales Island, southeast Alaska, and preliminary scanning electron microprobe studies: in Bradley, D., and DuselBacon, C., eds., 1992 Geologic Studies in Alaska: U.S. Geological Survey Bulletin 2068, p. 187-196.

Philpotts, J.A., Taylor, C.D., and Baedecker, P.A., 1996, Rare earth enrichment at Bokan Mountain, southeast Alaska: in Moore, T., and Dumoulin, J.D., eds., Geological studies in Alaska by the U.S.Geological Survey, 1994: U.S. Geological Survey Bulletin 2152, p. 89-100.

Philpotts, J.A., Taylor, C.D., Tatsumoto, Mitsunobu, and Belkin, H.E., 1998, Petrogenesis of late-stage granites and Y-REE-Zr-Nb-enriched vein dikes of the 
Bokan Mountain stock, Prince of Wales Island, southeastern Alaska, U.S. Geological Survey Open File Report, OFR 98-459, 71 p.

Plafker, George, and Berg, H.C., 1994, Overview of the geology and tectonic evolution of Alaska: in Plafker, George and Berg, H.C., (eds.) The geology of Alaska, v. G1, pp. 989-1021.

Race, W.H., 1963, Property examination report, Castle Island barite deposit, Duncan Canal, Alaska, Petersburg quadrangle: State of Alaska Division of Mines and Minerals, $13 \mathrm{p}$.

Rubin, C.M., and Saleeby, J.B., 1992, Tectonic history of the eastern edge of the Alexander terrane, southeast Alaska: Tectonics, v. 11, no. 3, pp. 586-602.

Saleeby, J.B., 1994, Tectonic history of the Insular Suture Zone, southeastern Alaska: Geological Society of America Abstracts v. 26, p. A384.

Savage, N.M., 1994, Terrane affinities of Middle and Late Devonian conodonts from the Wadleigh limestone, southeastern Alaska: Geological Society of America Abstracts v. 26, p. A158.

Smith, A.D., 1993, Geochemistry and tectonic setting of volcanics from the Anyox mining camp, British Columbia: Canadian Journal of Earth Science, v. 30, pp. 4859.

Smith, A.D., and Fox, J.S., 1989, Geochemistry of basalts from the Windy Craggy and Anyox volcanogenic massive sulfide deposits, British Columbia: Geological Association of Canada/Mineralogical Association of Canada Program with Abstracts, v. 14, p. A22.

Taylor, C.D., 1997, An arc-flank to back-arc transect: Metallogeny of late Triassic volcanogenic massive sulfide occurrences of the Alexander terrane, southeastern Alaska and British Columbia: [extended abs.] in Society of Economic Geologists Neves Corvo Field Conference, May 7-17, 1997, Lisbon, Portugal, Abstracts and Programs volume, p. 68.

Taylor, C.D., Cieutat, B.A., and Miller, L.D., 1992, A follow-up geochemical survey of base metal anomalies in the Ward Creek/Windfall Harbor and Gambier Bay areas, Admiralty Island S.E. Alaska in Bradley, D., and Dusel-Bacon, C., (eds.), 1991 Geologic Studies in Alaska: U.S. Geological Survey Bulletin 2041, p. 70-85.

Taylor, C.D., Goldfarb, R.J., Snee, L.W., Gent, C.A., Karl, S.M., and Haeussler, P.J., 1994, New age data for gold deposits and granites, Chichagof mining district, SE Alaska: evidence for a common origin: Geological Society of America Abstracts v. 26, p. A140. 
Taylor, C., Philpotts, J., Sutley, S., Gent, C., Harlan, S., Premo, W., Tatsumoto, M., Emsbo, P., and Meier, A., 1995a, Geochemistry of late Triassic volcanic rocks and age of alteration associated with volcanogenic massive sulfide occurrences, Alexander terrane, southeast Alaska, in Geology and ore deposits of the American cordillera, p. A74.

Taylor, C.D., Philpotts, J.A., Hall, T.E., and Wakeman, B.W., 1995b, New information on the geochemistry, age, and tectonic history of late Triassic volcanic host rocks and associated massive sulfide occurrences of the Alexander terrane, southeast Alaska, in Alaska Miners' Assoc., Conference Juneau, pp. 31-32.

Taylor, C. D., Premo, W. R., and Meier, A. L., 1999a, The late Triassic metallogeny of the Alexander terrane, southeastern Alaska and British Columbia: Geological Society of America Abstracts with Programs, v. 31, no. 6, p. A-101.

Taylor, C. D., Newkirk, S. R., Hall, T. E., Lear, K.G., Premo, W. R., Leventhal, J. S., Meier, A. L., Johnson, C. A. and Harris, A.G., 1999b, The Greens Creek deposit, southeastern Alaska: A VMS-SEDEX hybrid, in Mineral deposits: Processes to Processing, Stanley, C. J., et al., eds., Balkema, Rotterdam, v. 1, pp. 597-600.

Taylor, C. D., Premo, W. R., and Lear, K. G., 2000a, The Greens Creek massive sulfide deposit: Premier example of the late Triassic metallogeny of the Alexander terrane, southeastern Alaska and British Columbia: Geological Society of America Abstracts with Programs, v. 32, no. 6, p. A-71.

Taylor, C. D., Leventhal, J. S., Johnson, C. A., and Lear, K.G., 2000b, The Greens Creek massive sulfide deposit, southeastern Alaska: Stable isotopic evidence for the involvement of biogenic sulfate reduction in the formation of ores and carbonates, in Gemmell, J.B., and Pongratz, J., eds., Volcanic Environments and Massive Sulfide Deposits, Program and Abstracts, CODES Special Publication 3, pp. 209210.

Twenhofel, W.S., Reed, J.C., and Gates, G.O., 1951, Some mineral investigations in southeastern Alaska: U. S. Geological Survey Bulletin 963-A, pp. 1-46.

Williams, J.A., and Decker, P.A., 1932, Exploring Castle Island barite deposit by diamond drilling, a compilation: unpublished report available from the Juneau office of the U. S. Bureau of Land Management, listing \# MR 117-1, 46 p.

Woodsworth, G.J., and Orchard, M.J., 1985, Upper Paleozoic to lower Mesozoic strata and their conodonts, western Coast plutonic complex, British Columbia: Canadian Journal of Earth Science, v. 22, pp. 1329-1344.

Wright, F.U., and Wright, C.W., 1908, The Ketchikan and Wrangell mining districts, Alaska, U. S. Geological Survey Bulletin 347, 210 p. 
Zelinski, W., 1979?, Termination report, Behm Canal Project (D-77-36), southeastern, Alaska (unpublished): Amoco Minerals Company, 5 p. 


\section{FIGURE CAPTIONS}

Figure 1. Map showing locations of mines, prospects, and occurrences described in the text. Modified from McCafferty and others (this report). 


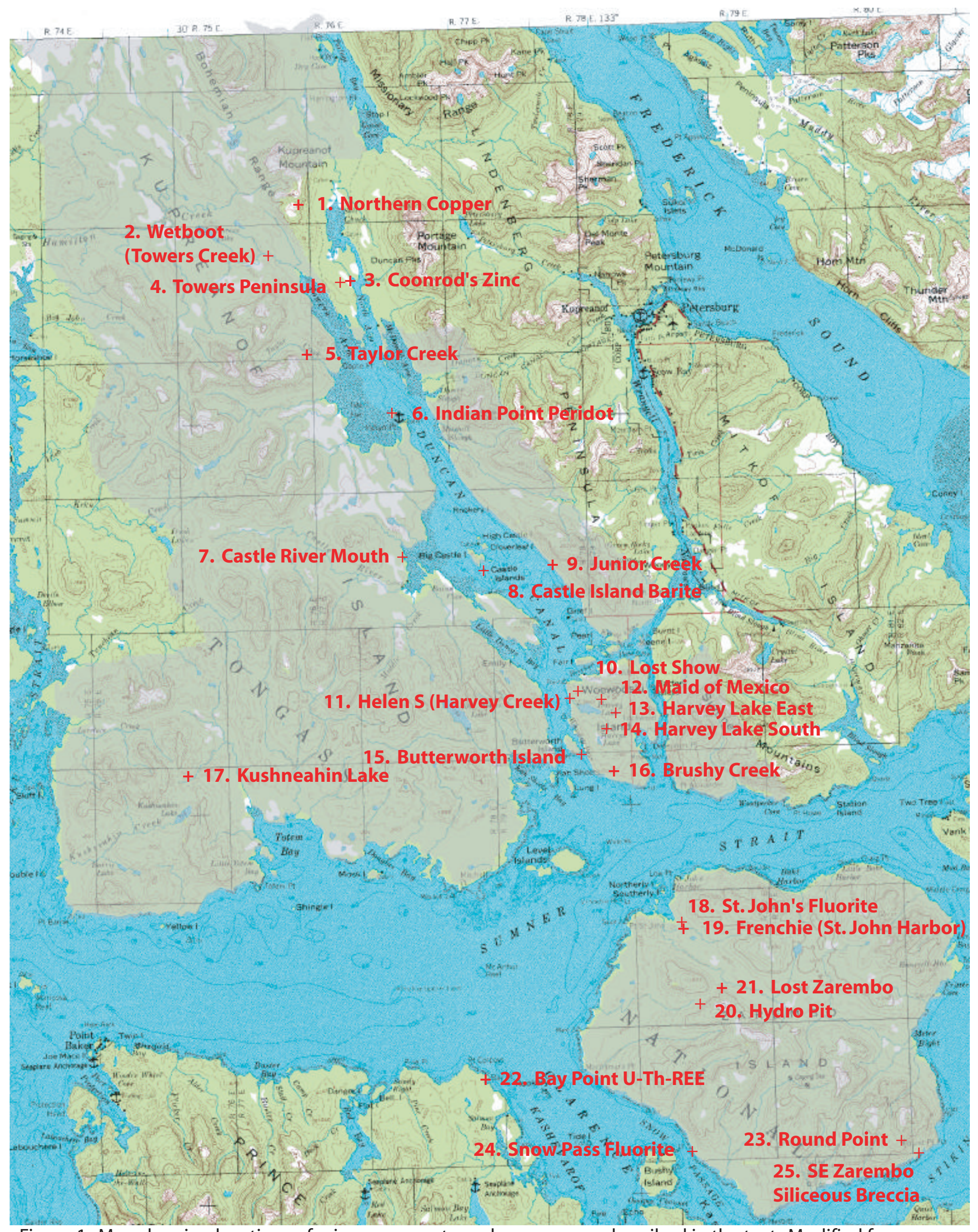

Figure 1. Map showing locations of mines, prospects, and occurrences described in the text. Modified from McCafferty and others, (this report). 


\section{TABLE CAPTIONS}

Table 1. Results of ICP-40 and CO2 geochemical analyses of non-mineralized igneous rocks from the Stikine Geophysical Survey Project area.

Table 2. Results of ICP-10, ICP-40, Au, Hg, total-C, total-S, and CO2 geochemical analyses of non-mineralized sedimentary rocks from the Stikine Geophysical Survey Project area.

Table 3. Results of ICP-10, ICP-40, Au, Hg, and CO2 geochemical analyses of mineralized rocks from the Stikine Geophysical Survey Project area.

Table 4. Major characteristics of mineral occurrences in the Stikine Geophysical Survey Project area. 
Table 1. Results of ICP-40 and $\mathrm{CO}_{2}$ geochemical analyses of non-mineralized igneous rocks from the Stikine Geophysical Survey Project area.

\begin{tabular}{|c|c|c|c|c|}
\hline Sample \# & Location & Rock type & Description & Age \\
\hline 98DC-01 & Woewodski Island NW shore & gabbro & coarse crystalline, brecciated, non-foliated & Triassic (?) \\
\hline 98DC-02 & Woewodski Island NW shore & gabbro & coarse crystalline, massive, non-foliated & Triassic (?) \\
\hline 98DC-03 & Woewodski Island NW tip at marker & gabbro & coarse crystalline, brecciated, non-foliated & Triassic (?) \\
\hline 98DC-04 & Woewodski Island north shore & diabase dike & pristine; crosscuts mafic volcaniclastic & Tertiary-Quaternary \\
\hline 98DC-06 & Woewodski Island north shore & basalt & thin mafic flow & Triassic (?) \\
\hline 98DC-07 & Woewodski Island north shore & felsic (?) tuff & $20 \mathrm{~cm}$ interbed in argillite; greenish, pyritic & Triassic (?) \\
\hline 98DC-10 & Woewodski Island north shore & gabbro & massive, dark green & Triassic (?) \\
\hline 98DC-11 & Woewodski Island north shore & diabase dike & straight, unalt'd, unfoliated; cuts calcareous sediments & Tertiary-Quaternary \\
\hline 98DC-16 & Northern Copper & greenschist & green, semischist-graywacke over top of opencut & Devonian \\
\hline 98DC-17 & Northern Copper & hornfels & black, planar bedded, schistose, hornfelsed greenschist & Devonian \\
\hline 98DC-18 & Portage Bay, west shore & basaltic dike & $3 \mathrm{~m}$ wide; distinct, black, glassy, chill margin & Tertiary-Quaternary \\
\hline 98DC-19 & Portage Bay, west shore & diorite & fine crystalline, porph-aph intrusive; similar to dike & Cretaceous \\
\hline 98DC-27 & Junior Creek & felsic (?) crystal tuff & interbedded black argillite and pyritic crystal tuff & Triassic(?) \\
\hline 98DC-33 & Lost Show & mafic volcanic & alt'd greenstone & Triassic(?) \\
\hline 98DC-38 & Taylor Creek & diorite & fine crystalline, $0.3 \mathrm{~m}$ wide dike with hairline pyrite-filled fractures & Cretaceous(?) \\
\hline 98DC-39 & Taylor Creek & greenschist & $50 \mathrm{~m}$ upcreek from the pyrite concretions in the creek bank & Triassic \\
\hline 98DC-42 & Koonrod's Zinc & qtz-ser-schist & country rock $61 \mathrm{~m}$ north of vein; foliated medium-gray & Devonian \\
\hline $98 D C-43$ & Koonrod's Zinc & greenschist & country rock $137 \mathrm{~m}$ north of vein; foliated medium-dark green & Devonian \\
\hline 98DC-46 & Towers Peninsula & gabbro & fresh, massive, high-standing outcrop $183 \mathrm{~m} \mathrm{NW}$ of occurrence & Triassic (?) \\
\hline 98DC-48 & Wetboot (Towers Creek) & phyllite & thin-bedded, foliated green-grayschist with limestone interbeds & Triassic(?) \\
\hline 98DC-51 & Towers Creek 0.4 km downstream & greenschist & from falls; probably is a chloritic, crystal tuff & Triassic(?) \\
\hline 98DC-53A & Hamilton Creek valley Sec. 2 & basalt & massive, fine crystalline greenstone in borrow pit & Triassic \\
\hline 98DC-54 & Hamilton Creek valley Sec. 12 & greenschist & dark green greenschist in borrow pit & Triassic \\
\hline 98DC-55 & Castle River mouth & basalt & top surface of a columnar flow & Triassic \\
\hline 98DC-59 & Castle River mouth & basaltic dike & dike crosscuts bedding and is in-between the occurrences & Tertiary(?) \\
\hline 98DC-61 & south Fankhauser flat & basalt & pyroxene porph basalt & Quaternary \\
\hline 98DC-62 & North shore Castle River Bay & basalt & thin basalt flows & Triassic \\
\hline 98DC-63 & southeastern shore Fankhauser flat & basalt & blocky, chl-ep-rich greenstone & Triassic \\
\hline 98DC-64 & southeastern shore Fankhauser flat & basalt & massive, unveined, columnar flow or dike & Quaternary \\
\hline 98DC-65 & Cloverleaf Island north side & basalt & blocky shattered greenstone & Triassic \\
\hline 98DC-66 & Cloverleaf Island north side & basalt & blocky shattered pillow basalt & Triassic \\
\hline 98DC-67 & Cloverleaf Island north side & basalt & blocky shattered pillow basalt & Triassic \\
\hline 98DC-68 & Indian Point Peridot & peridotite xenolith & peridotite xenoliths in massive brown columnar basalt & Quaternary \\
\hline 98DC-69 & Indian Point Peridot & basalt & peridotite xenoliths in massive brown columnar basalt & Quaternary \\
\hline 98DC-70 & Indian Point narrows & basalt/microgabbro & outcrop of blocky greenstone in foliated ser-chl-schist & Triassic (?) \\
\hline 98DC-71 & east Fankhauser flat & basalt/microgabbro & blocky greenstone in foliated chert-argillite & Triassic (?) \\
\hline 98DC-72 & east Fankhauser flat, NE 1/4 Sec. 26 & basalt/microgabbro & shattered chl-ep alt'd greenstone, blocky, coarse crystalline & Triassic (?) \\
\hline 98DC-73 & east Fankhauser flat, NE 1/4 Sec. 26 & basalt & scoriacious, pyroxene-bearing basalt & Quaternary \\
\hline 98DC-74 & east Fankhauser flat, east side Sec. 26 & basaltic dike & blocky, 3.0-4.5 m thick, weakly foliated $\mathrm{w}$ sheared margins & Triassic (?) \\
\hline 98DC-75 & east Fankhauser flat, east side Sec. 26 & basaltic dike & blocky, 3.0-4.5 m thick, with weakly foliated with sheared margins & Triassic (?) \\
\hline 98DC-76 & east Fankhauser flat, east side Sec. 26 & basalt & scoriacious, pyroxene-bearing basalt & Quaternary \\
\hline 98DC-77 & Ridge south of Taylor Creek & basalt & massive, blocky cliff of mafic volcanics with squashed pillows & Triassic \\
\hline
\end{tabular}


Table 1. Re

\begin{tabular}{|c|c|c|c|c|c|c|c|c|c|c|c|c|c|c|c|}
\hline Sample \# & Unit & DD Lat & DD Long & $\begin{array}{r}\text { C_ICP40 } \\
\text { Al } \\
\%\end{array}$ & $\begin{array}{r}\text { C_ICP40 } \\
\text { Ca } \\
\%\end{array}$ & $\begin{array}{r}\text { C_ICP40 } \\
\text { Fe } \\
\%\end{array}$ & $\begin{array}{r}\text { C_ICP40 } \\
\text { K } \\
\%\end{array}$ & $\begin{array}{r}\text { C_ICP40 } \\
\text { Mg } \\
\%\end{array}$ & $\begin{array}{r}\text { C_ICP40 } \\
\mathrm{Na} \\
\%\end{array}$ & $\begin{array}{r}\text { C_ICP40 } \\
\text { P } \\
\%\end{array}$ & $\begin{array}{r}\text { C_ICP40 } \\
\mathrm{Ti} \\
\%\end{array}$ & $\begin{array}{r}\text { C_ICP40 } \\
\text { Ag } \\
\text { ppm }\end{array}$ & $\begin{array}{r}\text { C_ICP40 } \\
\text { As } \\
\text { ppm }\end{array}$ & $\begin{array}{r}\text { C_ICP40 } \\
\text { Au } \\
\text { ppm }\end{array}$ & $\begin{array}{r}\text { C_ICP40 } \\
\text { Ba } \\
\text { ppm }\end{array}$ \\
\hline$\overline{98 D C-01}$ & Mzg & 56.5667 & 133.0667 & 10 & 5.92 & 7.16 & 0.75 & 4.65 & 2.142 & 0.065 & 0.792 & $<2$ & $<10$ & $<8$ & 260 \\
\hline 98DC-02 & Mzg & 56.5667 & 133.0667 & 9.955 & 6.845 & 7.66 & 0.14 & 3.705 & 1.601 & 0.06 & 0.906 & $<2$ & $<10$ & $<8$ & 126 \\
\hline 98DC-03 & Mzg & 56.5667 & 133.0667 & 8.44 & 7.52 & 7.53 & 0.37 & 3.775 & 1.42 & 0.05 & 1.056 & $<2$ & $<10$ & $<8$ & 125 \\
\hline 98DC-04 & QTd & 56.5667 & 133.0667 & 8.325 & 5.785 & 7.75 & 0.05 & 4.72 & 3.059 & 0.04 & 0.816 & $<2$ & $<10$ & $<8$ & 98 \\
\hline 98DC-06 & Trhv & 56.5667 & 133.0667 & 7.935 & 4.3 & 8.24 & 0.66 & 4.475 & 3.021 & 0.055 & 0.942 & $<2$ & $<10$ & $<8$ & 3140 \\
\hline 98DC-07 & Trsv & 56.5667 & 133.0667 & 5.035 & 12.3 & 5.96 & 2.04 & 6.355 & 0.366 & 0.085 & 0.492 & $<2$ & 18 & $<8$ & 1860 \\
\hline 98DC-10 & Mzg & 56.5667 & 133.0500 & 7.295 & 5.615 & 6.47 & 1.43 & 7.28 & 1.031 & 0.035 & 0.318 & $<2$ & $<10$ & $<8$ & 793 \\
\hline 98DC-11 & QTd & 56.5833 & 133.0500 & 7.43 & 4.855 & 9.82 & 1.31 & 1.8 & 2.893 & 0.35 & 1.494 & $<2$ & 11 & $<8$ & 931 \\
\hline 98DC-16 & Dsv & 56.8833 & 133.3667 & 8.995 & 3.76 & 9.37 & 0.73 & 4.27 & 2.983 & 0.03 & 0.516 & $<2$ & $<10$ & $<8$ & 1930 \\
\hline 98DC-17 & Dsv & 56.8833 & 133.3667 & 2.45 & 0.88 & 2.6 & 0.19 & 0.72 & 0.855 & 0.075 & 0.228 & $<2$ & $<10$ & $<8$ & 551 \\
\hline 98DC-18 & QTd & 56.9500 & 133.3000 & 8.45 & 3.765 & 10 & 2.04 & 4.39 & 2.218 & 0.175 & 2.052 & $<2$ & 23 & $<8$ & 6690 \\
\hline 98DC-19 & Kqo & 56.9500 & 133.3000 & 9.78 & 8.35 & 8.66 & 0.79 & 3.6 & 2.066 & 0.4 & 0.834 & $<2$ & $<10$ & $<8$ & 238 \\
\hline 98DC-27 & Trha & 56.6500 & 133.0833 & 4.91 & 16.7 & 1.75 & 1.46 & 0.655 & 1.553 & 0.09 & 0.144 & $<2$ & $<10$ & $<8$ & 713 \\
\hline 98DC-33 & Trhv & 56.5667 & 133.0500 & 8.46 & 7.915 & 6.73 & 1.41 & 4.16 & 1.667 & 0.04 & 0.81 & $<2$ & $<10$ & $<8$ & 1280 \\
\hline 98DC-38 & $\mathrm{Kqo}(?)$ & 56.7833 & 133.3500 & 7.94 & 5.67 & 8.99 & 0.5 & 3.185 & 2.218 & 0.115 & 1.506 & $<2$ & 16 & $<8$ & 1550 \\
\hline 98DC-39 & Trh & 56.7833 & 133.3500 & 7.435 & 3.865 & 7.97 & 0.46 & 5.105 & 1.995 & 0.08 & 0.984 & $<2$ & $<10$ & $<8$ & 680 \\
\hline 98DC-42 & Dsv & 56.8333 & 133.3000 & 4.91 & 5.62 & 2.6 & 0.96 & 0.54 & 1.862 & 0.06 & 0.096 & $<2$ & 43 & $<8$ & 165 \\
\hline 98DC-43 & Dsv & 56.8333 & 133.3000 & 9.915 & 5.51 & 7.54 & 0.3 & 3.315 & 3.24 & 0.11 & 0.714 & $<2$ & $<10$ & $<8$ & 105 \\
\hline 98DC-46 & Mzg & 56.8333 & 133.3167 & 9.03 & 8.32 & 7.39 & 1 & 4.2 & 1.397 & 0.06 & 0.552 & $<2$ & $<10$ & $<8$ & 350 \\
\hline 98DC-48 & Trha & 56.8500 & 133.4000 & 7.075 & 10.9 & 6.39 & 0.21 & 2.105 & 3.572 & 0.05 & 1.122 & $<2$ & 18 & $<8$ & 73 \\
\hline 98DC-51 & Trha & 56.8500 & 133.3833 & 9.55 & 3.165 & 8.37 & 0.14 & 2.435 & 4.437 & 0.08 & 1.314 & $<2$ & $<10$ & $<8$ & 310 \\
\hline 98DC-53A & Trh & 56.8500 & 133.5333 & 6.02 & 0.65 & 5.42 & 1.94 & 0.805 & 2.076 & 0.055 & 0.414 & $<2$ & $<10$ & 8 & 784 \\
\hline 98DC-54 & Trh & 56.8500 & 133.5333 & 5.76 & 2.14 & 11.1 & 0.75 & 3.09 & 1.791 & 0.135 & 0.87 & $<2$ & $<10$ & $<8$ & 310 \\
\hline 98DC-55 & Trh & 56.6500 & 133.2500 & 7.96 & 4.755 & 7.75 & 1.24 & 2.24 & 2.893 & 0.185 & 1.434 & $<2$ & 17 & $<8$ & 708 \\
\hline 98DC-59 & $\mathrm{Ti}$ & 56.6667 & 133.2500 & 8.065 & 5.935 & 8.66 & 0.75 & 3.2 & 2.518 & 0.145 & 1.488 & $<2$ & 12 & $<8$ & 419 \\
\hline 98DC-61 & $\mathrm{Qb}$ & 56.6667 & 133.2333 & 8.35 & 6.12 & 8.24 & 0.44 & 5.84 & 2.161 & 0.065 & 0.9 & $<2$ & $<10$ & $<8$ & 190 \\
\hline 98DC-62 & Trh & 56.6667 & 133.2333 & 7.535 & 5.47 & 9.92 & 1.02 & 2.315 & 2.684 & 0.225 & 2.286 & $<2$ & 21 & $<8$ & 516 \\
\hline 98DC-63 & Trhv & 56.6667 & 133.2167 & 7.34 & 4.98 & 9.28 & 1.23 & 3.065 & 2.404 & 0.14 & 1.302 & $<2$ & 17 & $<8$ & 1570 \\
\hline 98DC-64 & $\mathrm{Qb}$ & 56.6667 & 133.2167 & 7.535 & 4.59 & 9.59 & 1.03 & 2.205 & 2.679 & 0.215 & 2.238 & $<2$ & 17 & $<8$ & 519 \\
\hline 98DC-65 & Trha & 56.6667 & 133.1667 & 7.715 & 6.615 & 7.6 & 0.23 & 3.445 & 2.655 & 0.065 & 1.212 & $<2$ & 12 & $<8$ & 180 \\
\hline 98DC-66 & Trhv & 56.6667 & 133.1500 & 7.875 & 7.37 & 9.27 & 0.17 & 3.655 & 1.606 & 0.055 & 0.984 & $<2$ & $<10$ & $<8$ & 222 \\
\hline 98DC-67 & Trhv & 56.6667 & 133.1500 & 7.09 & 5.6 & 8.21 & 1.13 & 3.655 & 2.551 & 0.05 & 0.804 & $<2$ & $<10$ & $<8$ & 3780 \\
\hline 98DC-68 & $\mathrm{Qb}$ & 56.7500 & 133.2500 & 1.205 & 2.2 & 6.29 & 0.01 & 26 & 0.19 & $<0.005$ & 0.06 & $<2$ & $<10$ & $<8$ & 11 \\
\hline 98DC-69 & $\mathrm{Qb}$ & 56.7500 & 133.2500 & 7.25 & 5.635 & 7.7 & 0.89 & 9.52 & 2.09 & 0.16 & 1.416 & $<2$ & $<10$ & $<8$ & 275 \\
\hline 98DC-70 & Mzg & 56.7333 & 133.2500 & 7.535 & 5.98 & 8.11 & 1.12 & 4.335 & 2.114 & 0.06 & 0.936 & $<2$ & $<10$ & $<8$ & 982 \\
\hline 98DC-71 & Mzg & 56.7333 & 133.2333 & 8.465 & 7.34 & 9.1 & 0.11 & 5.12 & 2.138 & 0.045 & 0.804 & $<2$ & $<10$ & $<8$ & 194 \\
\hline 98DC-72 & Mzg & 56.7167 & 133.2167 & 7.395 & 5.695 & 9.95 & 0.05 & 4.135 & 2.176 & 0.075 & 1.356 & $<2$ & 12 & $<8$ & 140 \\
\hline 98DC-73 & $\mathrm{Qb}$ & 56.7167 & 133.2167 & 8.895 & 6.28 & 7.8 & 0.39 & 5.315 & 2.247 & 0.055 & 0.762 & $<2$ & $<10$ & $<8$ & 196 \\
\hline 98DC-74 & Trhv & 56.7167 & 133.2167 & 11.2 & 8.03 & 8.68 & 0.04 & 6.1 & 0.755 & 0.065 & 0.582 & $<2$ & 12 & $<8$ & 157 \\
\hline 98DC-75 & Trhv & 56.7167 & 133.2167 & 8.92 & 8.045 & 7.16 & 0.03 & 4.39 & 1.226 & 0.06 & 0.51 & $<2$ & $<10$ & $<8$ & 84 \\
\hline 98DC-76 & $\mathrm{Qb}$ & 56.7167 & 133.2167 & 9.115 & 4.72 & 7.05 & 1.01 & 2.83 & 2.874 & 0.145 & 1.296 & $<2$ & 13 & $<8$ & 487 \\
\hline 98DC-77 & Trhv & 56.7667 & 133.4000 & 8.78 & 6.03 & 6.75 & 0.13 & 3.24 & 3.567 & 0.035 & 0.774 & $<2$ & $<10$ & $<8$ & 61 \\
\hline
\end{tabular}


Table 1. Re

\begin{tabular}{|c|c|c|c|c|c|c|c|c|c|c|c|c|c|c|c|c|}
\hline Sample \# & $\begin{array}{r}\text { C_ICP40 } \\
\text { Be } \\
\text { ppm }\end{array}$ & $\begin{array}{r}\text { C_ICP40 } \\
\text { Bi } \\
\text { ppm } \\
\end{array}$ & $\begin{array}{r}\text { C_ICP40 } \\
\text { Cd } \\
\text { ppm } \\
\end{array}$ & $\begin{array}{r}\text { C_ICP40 } \\
\text { Ce } \\
\text { ppm }\end{array}$ & $\begin{array}{r}\text { C_ICP40 } \\
\text { Co } \\
\text { ppm }\end{array}$ & $\begin{array}{r}\text { C_ICP40 } \\
\text { Cr } \\
\text { ppm } \\
\end{array}$ & $\begin{array}{r}\text { C_ICP40 } \\
\text { Cu } \\
\text { ppm }\end{array}$ & $\begin{array}{r}\text { C_ICP40 } \\
\text { Eu } \\
\text { ppm } \\
\end{array}$ & $\begin{array}{r}\text { C_ICP40 } \\
\text { Ga } \\
\text { ppm } \\
\end{array}$ & $\begin{array}{r}\text { C_ICP40 } \\
\text { Ho } \\
\text { ppm }\end{array}$ & $\begin{array}{r}\text { C_ICP40 } \\
\text { La } \\
\text { ppm } \\
\end{array}$ & $\begin{array}{r}\text { C_ICP40 } \\
\text { Li } \\
\text { ppm } \\
\end{array}$ & $\begin{array}{r}\text { C_ICP40 } \\
\text { Mn } \\
\text { ppm }\end{array}$ & $\begin{array}{r}\text { C_ICP40 } \\
\text { Mo } \\
\text { ppm }\end{array}$ & $\begin{array}{r}\text { C_ICP40 } \\
\text { Nb } \\
\text { ppm }\end{array}$ & $\begin{array}{r}\text { C_ICP40 } \\
\text { Nd } \\
\text { ppm } \\
\end{array}$ \\
\hline $98 \mathrm{DC}-01$ & $<1$ & 34 & $<2$ & 19 & 29 & 149 & 163 & $<2$ & $<4$ & $<4$ & 5 & 25 & 1080 & $<2$ & 16 & 20 \\
\hline 98DC-02 & $<1$ & 23 & 2 & 18 & 34 & 55 & 199 & 2 & 26 & $<4$ & 5 & 7 & 904 & $<2$ & 14 & 22 \\
\hline 98DC-03 & $<1$ & 44 & 2 & 13 & 33 & 128 & 160 & 2 & 18 & $<4$ & 4 & 13 & 1130 & $<2$ & 15 & 19 \\
\hline 98DC-04 & $<1$ & 28 & 2 & 17 & 42 & 67 & 133 & 2 & 10 & $<4$ & 3 & 19 & 1020 & $<2$ & 13 & 22 \\
\hline 98DC-06 & $<1$ & 46 & 3 & 24 & 36 & 95 & 190 & 3 & 12 & $<4$ & 7 & 23 & 1410 & $<2$ & 13 & 28 \\
\hline 98DC-07 & 1 & 18 & $<2$ & 21 & 37 & 157 & 100 & $<2$ & $<4$ & $<4$ & 9 & 17 & 1200 & $<2$ & 12 & 16 \\
\hline 98DC-10 & $<1$ & 14 & 2 & 14 & 43 & 229 & 49 & $<2$ & $<4$ & $<4$ & 4 & 22 & 1030 & $<2$ & 14 & 16 \\
\hline 98DC-11 & 2 & 62 & 3 & 74 & 18 & 8 & 16 & 6 & 33 & $<4$ & 28 & 8 & 2120 & 3 & 14 & 59 \\
\hline 98DC-16 & $<1$ & 20 & 3 & 7 & 38 & 45 & 6 & $<2$ & $<4$ & $<4$ & 3 & 15 & 3840 & $<2$ & 10 & 23 \\
\hline 98DC-17 & $<1$ & $<10$ & $<2$ & 24 & 9 & 23 & 179 & $<2$ & 16 & $<4$ & 12 & $<2$ & 442 & 68 & 7 & 12 \\
\hline 98DC-18 & 2 & 78 & 5 & 62 & 40 & 3 & 46 & 5 & 31 & $<4$ & 22 & 12 & 1450 & $<2$ & 25 & 55 \\
\hline 98DC-19 & $<1$ & 43 & 2 & 45 & 32 & $<2$ & 88 & 3 & 17 & $<4$ & 16 & 5 & 1830 & $<2$ & 12 & 43 \\
\hline 98DC-27 & 1 & $<10$ & $<2$ & 21 & 22 & 121 & 62 & $<2$ & 11 & $<4$ & 8 & 3 & 918 & $<2$ & 6 & $<9$ \\
\hline 98DC-33 & $<1$ & 29 & 2 & 17 & 34 & 133 & 235 & $<2$ & 15 & $<4$ & $<2$ & 14 & 996 & $<2$ & 16 & 17 \\
\hline 98DC-38 & 1 & 32 & 3 & 43 & 33 & 28 & 23 & 3 & 17 & $<4$ & 16 & 17 & 1400 & $<2$ & 16 & 36 \\
\hline 98DC-39 & $<1$ & 24 & 2 & 23 & 32 & 93 & 520 & 2 & 15 & $<4$ & 6 & 22 & 1140 & $<2$ & 17 & 25 \\
\hline 98DC-42 & 1 & $<10$ & $<2$ & 28 & 9 & 2 & 33 & $<2$ & 10 & $<4$ & 10 & 4 & 1150 & $<2$ & $<4$ & 11 \\
\hline 98DC-43 & $<1$ & 20 & 2 & 32 & 28 & 15 & 75 & $<2$ & 17 & $<4$ & 9 & 8 & 934 & $<2$ & 12 & 25 \\
\hline 98DC-46 & $<1$ & 21 & 3 & 7 & 36 & 103 & 150 & $<2$ & 14 & $<4$ & $<2$ & 3 & 1390 & $<2$ & 8 & 13 \\
\hline 98DC-48 & $<1$ & 31 & $<2$ & 15 & 26 & 25 & 155 & 2 & 15 & $<4$ & 4 & 17 & 1450 & $<2$ & 10 & 18 \\
\hline 98DC-51 & $<1$ & 17 & 2 & 28 & 27 & 53 & 62 & 2 & 34 & $<4$ & 9 & 15 & 953 & $<2$ & 17 & 31 \\
\hline 98DC-53A & 2 & $<10$ & $<2$ & 87 & 4 & $<2$ & 32 & 3 & 26 & $<4$ & 40 & 18 & 456 & 3 & 25 & 62 \\
\hline 98DC-54 & $<1$ & 35 & 3 & 40 & 38 & 3 & 331 & 3 & 24 & $<4$ & 13 & 25 & 1320 & $<2$ & 12 & 45 \\
\hline 98DC-55 & 2 & 40 & 3 & 67 & 22 & 10 & 8 & 3 & 26 & $<4$ & 26 & 9 & 1340 & $<2$ & 14 & 45 \\
\hline 98DC-59 & 1 & 17 & 3 & 49 & 32 & 17 & 16 & 3 & 25 & $<4$ & 16 & 11 & 1510 & $<2$ & 20 & 38 \\
\hline 98DC-61 & $<1$ & 20 & 2 & 20 & 44 & 118 & 29 & $<2$ & 6 & $<4$ & 6 & 6 & 1140 & $<2$ & 20 & 22 \\
\hline 98DC-62 & 2 & 68 & 3 & 67 & 27 & 4 & 17 & 4 & 31 & $<4$ & 22 & 11 & 1640 & $<2$ & 24 & 49 \\
\hline 98DC-63 & $<1$ & 41 & 3 & 38 & 30 & 58 & 145 & 2 & 18 & $<4$ & 12 & 11 & 1430 & $<2$ & 21 & 33 \\
\hline 98DC-64 & 2 & 80 & 3 & 61 & 26 & 6 & 17 & 4 & 32 & $<4$ & 22 & 9 & 1330 & 2 & 23 & 47 \\
\hline 98DC-65 & $<1$ & 79 & 2 & 22 & 36 & 82 & 205 & 2 & 22 & $<4$ & 5 & 15 & 1220 & $<2$ & 15 & 27 \\
\hline 98DC-66 & $<1$ & 36 & 2 & 20 & 38 & 40 & 208 & 3 & 18 & $<4$ & 6 & 19 & 1310 & $<2$ & 12 & 26 \\
\hline 98DC-67 & $<1$ & 30 & 4 & 23 & 36 & 71 & 196 & 2 & 16 & $<4$ & 5 & 17 & 1500 & $<2$ & 9 & 21 \\
\hline 98DC-68 & $<1$ & $<10$ & $<2$ & $<5$ & 93 & 332 & 35 & $<2$ & $<4$ & $<4$ & $<2$ & 2 & 983 & $<2$ & 31 & 9 \\
\hline 98DC-69 & 1 & 49 & 2 & 50 & 52 & 259 & 50 & 3 & $<4$ & $<4$ & 20 & 7 & 1140 & $<2$ & 39 & 32 \\
\hline 98DC-70 & $<1$ & 36 & 3 & 21 & 31 & 152 & 68 & $<2$ & 15 & $<4$ & 6 & 9 & 1330 & $<2$ & 16 & 19 \\
\hline 98DC-71 & $<1$ & 14 & 3 & 13 & 45 & 117 & 188 & 3 & 8 & $<4$ & 4 & 8 & 1370 & $<2$ & 14 & 20 \\
\hline 98DC-72 & $<1$ & 24 & 3 & 26 & 40 & 39 & 197 & 3 & 13 & $<4$ & 7 & 8 & 1630 & $<2$ & 18 & 33 \\
\hline 98DC-73 & 1 & 21 & 3 & 23 & 42 & 109 & 33 & 2 & 8 & $<4$ & 6 & 5 & 1080 & $<2$ & 16 & 19 \\
\hline 98DC-74 & $<1$ & 27 & 3 & $<5$ & 50 & 142 & 114 & $<2$ & 22 & $<4$ & $<2$ & 18 & 1360 & $<2$ & 13 & 17 \\
\hline 98DC-75 & $<1$ & 21 & 2 & 6 & 35 & 73 & 131 & $<2$ & 15 & $<4$ & $<2$ & 9 & 1170 & $<2$ & 12 & 13 \\
\hline 98DC-76 & 2 & 33 & 2 & 63 & 27 & 24 & 19 & 3 & 24 & $<4$ & 21 & 7 & 829 & $<2$ & 26 & 37 \\
\hline 98DC-77 & $<1$ & $<10$ & 2 & 13 & 29 & 75 & 80 & $<2$ & 15 & $<4$ & 3 & 11 & 1190 & $<2$ & 13 & 16 \\
\hline
\end{tabular}


Table 1. Re

\begin{tabular}{|c|c|c|c|c|c|c|c|c|c|c|c|c|c|c|}
\hline Sample \# & $\begin{array}{r}\text { C_ICP40 } \\
\mathrm{Ni}\end{array}$ & $\begin{array}{r}\text { C_ICP40 } \\
\text { Pb }\end{array}$ & $\begin{array}{r}\text { C_ICP40 } \\
\text { Sc }\end{array}$ & $\begin{array}{r}\text { C_ICP40 } \\
\text { Sn }\end{array}$ & $\begin{array}{r}\text { C_ICP40 } \\
\mathrm{Sr}\end{array}$ & $\begin{array}{r}\text { C_ICP40 } \\
\text { Ta }\end{array}$ & $\begin{array}{r}\text { C_ICP40 } \\
\text { Th }\end{array}$ & $\begin{array}{r}\text { C_ICP40 } \\
\text { U }\end{array}$ & $\begin{array}{r}\text { C_ICP40 } \\
\text { V }\end{array}$ & $\begin{array}{r}\text { C_ICP40 } \\
Y\end{array}$ & $\begin{array}{r}\text { C_ICP40 } \\
\text { Yb }\end{array}$ & $\begin{array}{r}\text { C_ICP40 } \\
\text { Zn }\end{array}$ & $\begin{array}{r}\mathrm{C}+\mathrm{CO} 2 \mathrm{C} \\
\mathrm{CO} 2\end{array}$ & $\begin{array}{l}\text { C_CO2 C } \\
\text { 冫RBNT_C }\end{array}$ \\
\hline & $\mathrm{ppm}$ & $\mathrm{ppm}$ & $\mathrm{ppm}$ & $\mathrm{ppm}$ & $\mathrm{ppm}$ & ppm & $\mathrm{ppm}$ & $\mathrm{ppm}$ & $\mathrm{ppm}$ & $\mathrm{ppm}$ & $\mathrm{ppm}$ & $\mathrm{ppm}$ & $\%$ & $\%$ \\
\hline 98DC-01 & 120 & $<4$ & 32 & $<5$ & 222 & $<40$ & $<6$ & $<100$ & 246 & 18 & 2 & 58 & 0.04 & $\overline{0.01}$ \\
\hline 98DC-02 & 91 & $<4$ & 31 & $<5$ & 141 & $<40$ & $<6$ & $<100$ & 260 & 21 & 3 & 75 & 0.33 & 0.09 \\
\hline 98DC-03 & 81 & $<4$ & 39 & $<5$ & 203 & $<40$ & $<6$ & $<100$ & 328 & 20 & 3 & 75 & $<0.01$ & $<0.003$ \\
\hline 98DC-04 & 109 & $<4$ & 38 & $<5$ & 137 & $<40$ & $<6$ & $<100$ & 260 & 18 & 2 & 70 & 1.95 & 0.53 \\
\hline 98DC-06 & 107 & $<4$ & 35 & $<5$ & 205 & $<40$ & $<6$ & $<100$ & 246 & 23 & 2 & 84 & 0.86 & 0.23 \\
\hline 98DC-07 & 81 & $<4$ & 37 & $<5$ & 97 & $<40$ & $<6$ & $<100$ & 216 & 16 & 2 & 47 & 27.8 & 7.59 \\
\hline 98DC-10 & 262 & $<4$ & 34 & $<5$ & 169 & $<40$ & $<6$ & $<100$ & 193 & 15 & 3 & 56 & 0.31 & 0.08 \\
\hline 98DC-11 & 4 & $<4$ & 31 & $<5$ & 315 & $<40$ & $<6$ & $<100$ & 103 & 52 & 5 & 152 & 0.15 & 0.04 \\
\hline 98DC-16 & 58 & $<4$ & 35 & $<5$ & 124 & $<40$ & $<6$ & $<100$ & 197 & 16 & 2 & 136 & $<0.01$ & $<0.003$ \\
\hline 98DC-17 & 105 & $<4$ & 6 & $<5$ & 43 & $<40$ & $<6$ & $<100$ & 792 & 21 & 3 & 64 & 0.26 & 0.07 \\
\hline 98DC-18 & 19 & $<4$ & 17 & $<5$ & 269 & $<40$ & $<6$ & $<100$ & 331 & 23 & 2 & 466 & $<0.01$ & $<0.003$ \\
\hline 98DC-19 & $<3$ & $<4$ & 22 & $<5$ & 1110 & $<40$ & $<6$ & $<100$ & 346 & 30 & 3 & 126 & 0.14 & 0.04 \\
\hline 98DC-27 & 94 & $<4$ & 21 & $<5$ & 514 & $<40$ & $<6$ & $<100$ & 157 & 18 & 2 & 49 & 20.1 & 5.49 \\
\hline 98DC-33 & 95 & $<4$ & 37 & $<5$ & 142 & $<40$ & $<6$ & $<100$ & 288 & 18 & 3 & 60 & 2.42 & 0.66 \\
\hline 98DC-38 & 19 & $<4$ & 32 & $<5$ & 327 & $<40$ & $<6$ & $<100$ & 310 & 33 & 4 & 122 & 9.26 & 2.53 \\
\hline 98DC-39 & 69 & $<4$ & 36 & $<5$ & 84 & $<40$ & $<6$ & $<100$ & 435 & 11 & 2 & 92 & 4.46 & 1.22 \\
\hline 98DC-42 & 7 & 8 & 10 & $<5$ & 145 & $<40$ & $<6$ & $<100$ & 96 & 14 & 2 & 47 & 6.23 & 1.7 \\
\hline $98 D C-43$ & 17 & $<4$ & 23 & $<5$ & 778 & $<40$ & $<6$ & $<100$ & 260 & 19 & 2 & 100 & 0.02 & 0.01 \\
\hline 98DC-46 & 70 & $<4$ & 42 & $<5$ & 510 & $<40$ & $<6$ & $<100$ & 325 & 17 & 3 & 70 & 0.19 & 0.05 \\
\hline 98DC-48 & 35 & $<4$ & 37 & $<5$ & 235 & $<40$ & $<6$ & $<100$ & 339 & 13 & 3 & 72 & 11.6 & 3.17 \\
\hline 98DC-51 & 52 & $<4$ & 37 & $<5$ & 135 & $<40$ & $<6$ & $<100$ & 336 & 28 & 3 & 167 & 2.09 & 0.57 \\
\hline 98DC-53A & 3 & $<4$ & 12 & $<5$ & 43 & $<40$ & 11 & $<100$ & 20 & 17 & 3 & 130 & 1.39 & 0.38 \\
\hline 98DC-54 & 16 & $<4$ & 32 & $<5$ & 119 & $<40$ & $<6$ & $<100$ & 240 & 29 & 3 & 127 & 3.14 & 0.86 \\
\hline 98DC-55 & $<3$ & 5 & 27 & $<5$ & 360 & $<40$ & 7 & $<100$ & 271 & 38 & 4 & 122 & 0.02 & 0.01 \\
\hline 98DC-59 & 12 & $<4$ & 30 & $<5$ & 377 & $<40$ & $<6$ & $<100$ & 266 & 29 & 3 & 117 & 3.09 & 0.84 \\
\hline 98DC-61 & 117 & $<4$ & 23 & $<5$ & 272 & $<40$ & $<6$ & $<100$ & 171 & 17 & 2 & 99 & $<0.01$ & $<0.003$ \\
\hline 98DC-62 & $<3$ & 6 & 32 & $<5$ & 313 & $<40$ & $<6$ & $<100$ & 278 & 45 & 5 & 149 & 1.36 & 0.37 \\
\hline 98DC-63 & 33 & $<4$ & 40 & $<5$ & 210 & $<40$ & $<6$ & $<100$ & 318 & 33 & 4 & 116 & 0.05 & 0.01 \\
\hline 98DC-64 & $<3$ & $<4$ & 31 & $<5$ & 319 & $<40$ & $<6$ & $<100$ & 259 & 43 & 5 & 155 & 1.06 & 0.29 \\
\hline 98DC-65 & 58 & $<4$ & 43 & $<5$ & 353 & $<40$ & $<6$ & $<100$ & 384 & 25 & 3 & 91 & 1.08 & 0.29 \\
\hline 98DC-66 & 52 & $<4$ & 40 & $<5$ & 278 & $<40$ & $<6$ & $<100$ & 320 & 25 & 3 & 95 & 0.25 & 0.07 \\
\hline 98DC-67 & 57 & $<4$ & 41 & $<5$ & 211 & $<40$ & $<6$ & $<100$ & 274 & 25 & 3 & 88 & 0.7 & 0.19 \\
\hline 98DC-68 & 1920 & $<4$ & 14 & $<5$ & 9 & $<40$ & $<6$ & $<100$ & 85 & 3 & 1 & 9 & 0.04 & 0.01 \\
\hline 98DC-69 & 483 & $<4$ & 23 & $<5$ & 445 & $<40$ & $<6$ & $<100$ & 196 & 20 & 2 & 84 & $<0.01$ & $<0.003$ \\
\hline 98DC-70 & 32 & $<4$ & 41 & $<5$ & 157 & $<40$ & $<6$ & $<100$ & 296 & 23 & 3 & 108 & 0.01 & $<0.003$ \\
\hline 98DC-71 & 107 & $<4$ & 47 & $<5$ & 358 & $<40$ & $<6$ & $<100$ & 302 & 23 & 3 & 90 & 0.07 & 0.02 \\
\hline 98DC-72 & 51 & $<4$ & 43 & $<5$ & 204 & $<40$ & $<6$ & $<100$ & 387 & 31 & 4 & 111 & 0.08 & 0.02 \\
\hline 98DC-73 & 99 & $<4$ & 21 & $<5$ & 285 & $<40$ & $<6$ & $<100$ & 146 & 16 & 2 & 100 & 0.01 & $<0.003$ \\
\hline 98DC-74 & 165 & 5 & 47 & $<5$ & $<2$ & $<40$ & $<6$ & $<100$ & 350 & 18 & 3 & 81 & 0.12 & 0.03 \\
\hline 98DC-75 & 83 & $<4$ & 39 & $<5$ & 596 & $<40$ & $<6$ & $<100$ & 295 & 15 & 2 & 73 & 0.5 & 0.14 \\
\hline 98DC-76 & 19 & $<4$ & 27 & $<5$ & 319 & $<40$ & $<6$ & $<100$ & 208 & 36 & 4 & 112 & 1.03 & 0.28 \\
\hline 98DC-77 & 53 & $<4$ & 39 & $<5$ & 142 & $<40$ & $<6$ & $<100$ & 250 & 20 & 3 & 77 & 1.85 & 0.5 \\
\hline
\end{tabular}




\begin{tabular}{|c|c|c|c|c|}
\hline Sample \# & Location & Rock type & Description & Age \\
\hline 98DC-78 & Ridge south of Taylor Creek & basalt & blocky, massive greenstone & Triassic \\
\hline 98DC-79 & West shore Little Duncan bay & gabbro & pyritic, foliated, blocky, alt'd & Triassic (?) \\
\hline 98DC-80 & West shore Little Duncan bay & gabbro & fine crystalline, blocky & Triassic (?) \\
\hline 98DC-81 & West shore Little Duncan bay & basalt & pyrite veined, alt'd basalt from borrow pit & Triassic (?) \\
\hline 98DC-82 & West shore Little Duncan bay & basalt & foliated, chloritic mafic volcanic from pit & Triassic (?) \\
\hline 98DC-83 & West shore Little Duncan bay & greenschist & chippy, light green to yellow; meta-volcaniclastic & Triassic (?) \\
\hline 98DC-84 & West shore Little Duncan bay & gabbro & plagioclase-rich intrusive rock from pit at beach & Triassic (?) \\
\hline 98DC-87 & Harvey Lake South & basalt & foliated mafic volcanic & Triassic (?) \\
\hline 98DC-89 & Harvey Lake East & basalt & foliated mafic volcanic & Triassic (?) \\
\hline 98DC-91 & Harvey Lake East & greenschist & dark greenish-black schist & Triassic (?) \\
\hline 98DC-93 & Butterworth Island & diorite & massive intrusive in outcrop just north of occurrence & Cretaceous \\
\hline 98DC-95 & Butterworth Island & greenschist & blocky, volcaniclastic textured greenschist & Triassic (?) \\
\hline 98DC-98 & Helen-S & basalt & mafic volcanic host rock & Triassic (?) \\
\hline 98DC-102 & Kushneahin Lake & rhyolite & chloritic, spherulitic rhyolite & Tertiary-Quaternary \\
\hline 98DC-106 & Kushneahin Lake & rhyolite & massive rhyolite & Tertiary-Quaternary \\
\hline 98DC-108 & Kushneahin Lake & rhyolite & massive, glassy, greenish-white rhyolite & Tertiary-Quaternary \\
\hline 98DC-109 & Lovelace Creek headwaters, Sec. 28 & rhyolite & dark maroon-gray banded crystal tuff, FLOAT & Tertiary-Quaternary \\
\hline 98DC-111 & Little Duncan Bay west side & gabbro sill & massive gabbro intruding sediments; iron-stained contacts & Triassic (?) \\
\hline 98DC-112 & Little Duncan Bay west side & greenstone & pyroxene porph flow or dike, with small black inclusions & Triassic (?) \\
\hline 98DC-113 & Little Duncan Bay west side & mafic volcanic & mafic pillowed flows and volcaniclastics & Triassic (?) \\
\hline 98DC-114 & Little Duncan Bay west side & pillow basalt & massive outcrop of pillow basalt in cliff & Triassic (?) \\
\hline 98ZA-05 & Frenchie & phyllite & black, non-calcareous phyllite immediately over massive sulfides & Triassic(?) \\
\hline 98ZA-06 & Borrow pit (Hydropit ?), Zarembo Island & microgabbro & fresh, micro-porph gabbro at back wall of pit & Cretaceous \\
\hline 98ZA-08 & Lost Zarembo & greenschist & siliceous greenschist away from mineralization & Triassic(?) \\
\hline $98 Z A-10$ & Round Point & basaltic dike & 1-m-thick porph, massive, unfoliated dike $4.5 \mathrm{~m}$ below sulfides & Triassic(?) \\
\hline 98ZA-11 & Round Point & qtz-musc-schist & unmineralized, schist $50 \mathrm{~m}$ upcreek from occurrence & Triassic(?) \\
\hline 98ZA-12 & SE Zarembo siliceous breccia & meta-graywacke & highly foliated dark gray to black phyllite with qtz bands & Triassic(?) \\
\hline 98ZA-15 & SE Zarembo siliceous breccia & mafic volcanic & blocky mafic volcanic, unfoliated & Triassic(?) \\
\hline 98ZA-18 & South shore, Zarembo Island & mafic dike & $1.2 \mathrm{~m}$ wide mafic dike in beach outcrop & Tertiary-Quaternary \\
\hline 98ZA-19 & South shore, Zarembo Island & rhyolite & fresh rhyolite & Tertiary-Quaternary \\
\hline 98ZA-20 & South shore, Zarembo Island & andesite & andesite & Tertiary-Quaternary \\
\hline 98ZA-21 & South shore, Zarembo Island & mafic dike & mafic dike with distinct chill margins & Tertiary-Quaternary \\
\hline 98ZA-22 & South shore, Zarembo Island & felsic dike & porph felsic dike adjacent to mafic dike & Tertiary-Quaternary \\
\hline 98ZA-23 & South shore, Zarembo Island & basalt & $0.6 \mathrm{~m}$ thick flow above conglomerate and under pillowed flow & Triassic(?) \\
\hline 98ZA-24 & South shore, Zarembo Island & felsic dike & $6 \mathrm{~m}$ wide with distinct chill margins & Tertiary-Quaternary \\
\hline ZAR\#1-01 & Frenchie, $\left(5^{\prime}\right)$ & greenschist & mottled green, silicified schist with hairline sulfide veinlets & Triassic (?) \\
\hline ZAR\#1-03 & Frenchie, $\left(40.5^{\prime}\right)$ & musc schist & sericitic, green-black; base of footwall musc-schist & Triassic (?) \\
\hline ZAR\#1-12 & Frenchie, (209') & argillite/tuff & $15 \mathrm{~cm}$ band of pyrite-carbonate rich green tuff in black argillite & Triassic (?) \\
\hline ZAR\#1-15 & Frenchie, $\left(277^{\prime}\right)$ & greenstone & massive foliated, chloritic, qtz veined greenstone & Triassic(?) \\
\hline ZAR\#1-17 & Frenchie, $\left(317^{\prime}\right)$ & greenschist & foliated, sericitic greenschist with minor pyrite; possible dike & Triassic(?) \\
\hline ZAR\#1-18 & Frenchie, $\left(325^{\prime}\right)$ & feldspar crystal tuff & light green to white feldspar crystal tuff (?) & Triassic(?) \\
\hline ZAR\#1-19 & Frenchie, $\left(483^{\prime}\right)$ & siliceous sediment & siliceous sediment & Triassic(?) \\
\hline ZAR\#2-05 & Frenchie, $\left(119^{\prime}\right)$ & tuff & interbed of ash tuff in argillite & Triassic (?) \\
\hline
\end{tabular}




\begin{tabular}{|c|c|c|c|c|c|c|c|c|c|c|c|c|c|c|c|}
\hline Sample \# & Unit & DD Lat & DD Long & $\begin{array}{r}\text { C_ICP40 } \\
\text { AI } \\
\%\end{array}$ & $\begin{array}{r}\text { C_ICP40 } \\
\text { Ca } \\
\%\end{array}$ & $\begin{array}{r}\text { C_ICP40 } \\
\text { Fe } \\
\%\end{array}$ & $\begin{array}{r}\text { C_ICP40 } \\
\text { K } \\
\%\end{array}$ & $\begin{array}{r}\text { C_ICP40 } \\
\text { Mg } \\
\%\end{array}$ & $\begin{array}{r}\text { C_ICP40 } \\
\mathrm{Na} \\
\%\end{array}$ & $\begin{array}{r}\text { C_ICP40 } \\
\text { P } \\
\%\end{array}$ & $\begin{array}{r}\text { C_ICP40 } \\
\text { Ti } \\
\%\end{array}$ & $\begin{array}{r}\text { C_ICP40 } \\
\text { Ag } \\
\text { ppm }\end{array}$ & $\begin{array}{r}\text { C_ICP40 } \\
\text { As } \\
\text { ppm }\end{array}$ & $\begin{array}{r}\text { C_ICP40 } \\
\text { Au } \\
\text { ppm }\end{array}$ & $\begin{array}{r}\text { C_ICP40 } \\
\text { Ba } \\
\text { ppm }\end{array}$ \\
\hline 98DC-78 & Trhv & 56.7667 & 133.3833 & 7.48 & 6.49 & 8.52 & 0.12 & 3.32 & 2.603 & 0.04 & 0.888 & $<2$ & $<10$ & $<8$ & 72 \\
\hline 98DC-79 & Mzg & 56.5833 & 133.1333 & 8.89 & 5.17 & 8.67 & 0.32 & 3.505 & 2.902 & 0.115 & 1.56 & $<2$ & 14 & $<8$ & 172 \\
\hline 98DC-80 & Mzg & 56.5667 & 133.1167 & 7.4 & 4.13 & 9.41 & 1.34 & 1.3 & 3.235 & 0.3 & 1.194 & $<2$ & $<10$ & $<8$ & 700 \\
\hline 98DC-81 & Trhsv & 56.5667 & 133.1167 & 0.4 & 18 & 17.9 & 0.14 & 0.355 & 0.024 & 0.93 & 0.036 & 2 & $<10$ & 12 & 341 \\
\hline 98DC-82 & Trhsv & 56.5667 & 133.1167 & 8.285 & 5.54 & 6.37 & 3.14 & 3.345 & 0.542 & 0.16 & 0.546 & $<2$ & $<10$ & $<8$ & 766 \\
\hline 98DC-83 & Trhsv & 56.5667 & 133.1000 & 9.25 & 2.385 & 3.8 & 1.75 & 1.835 & 3.031 & 0.07 & 0.624 & $<2$ & $<10$ & $<8$ & 729 \\
\hline 98DC-84 & Mzg & 56.5500 & 133.0833 & 9.205 & 3.095 & 4.86 & 2.64 & 1.54 & 3.805 & 0.12 & 0.522 & $<2$ & 15 & $<8$ & 437 \\
\hline 98DC-87 & Trhv & 56.5333 & 133.0167 & 7.86 & 6.345 & 9.27 & 0.37 & 3.095 & 3.249 & 0.065 & 1.236 & $<2$ & 36 & $<8$ & 4100 \\
\hline 98DC-89 & Trhv & 56.5500 & 133.0000 & 7.825 & 5.49 & 7.3 & 0.32 & 3.3 & 3.696 & 0.045 & 0.606 & $<2$ & $<10$ & $<8$ & 217 \\
\hline 98DC-91 & Trha & 56.5500 & 133.0000 & 8.435 & 0.75 & 4.47 & 1.02 & 1.825 & 3.544 & 0.08 & 0.402 & $<2$ & $<10$ & 8 & 492 \\
\hline 98DC-93 & Kdi & 56.5333 & 133.0500 & 7.765 & 6.9 & 7.4 & 0.57 & 4.965 & 2.313 & 0.05 & 0.828 & $<2$ & 11 & $<8$ & 319 \\
\hline 98DC-95 & Trhsv & 56.5167 & 133.0500 & 7.585 & 6.825 & 8.79 & 1.21 & 2.74 & 2.765 & 0.065 & 0.846 & $<2$ & $<10$ & $<8$ & 374 \\
\hline 98DC-98 & Trhv & 56.5667 & 133.0667 & 5.33 & 5.28 & 13.7 & 1.65 & 2.515 & 0.907 & 0.075 & 3.594 & 6 & 21 & $<8$ & 2520 \\
\hline 98DC-102 & QTr & 56.5167 & 133.5000 & 5.315 & 0.02 & 1.28 & 3.73 & 0.01 & 1.895 & $<0.005$ & 0.084 & $<2$ & $<10$ & $<8$ & 84 \\
\hline 98DC-106 & QTr & 56.5167 & 133.5000 & 6.59 & 0.315 & 0.54 & 3.5 & 0.06 & 1.682 & 0.005 & 0.102 & $<2$ & $<10$ & $<8$ & 375 \\
\hline 98DC-108 & QTr & 56.5167 & 133.5000 & 6.415 & 0.355 & 0.39 & 6.8 & 0.02 & 0.603 & 0.005 & 0.096 & $<2$ & 13 & $<8$ & 141 \\
\hline 98DC-109 & QTr & 56.5500 & 133.5500 & 4.965 & 0.015 & 5 & 3.74 & 0.01 & 1.758 & $<0.005$ & 0.234 & $<2$ & $<10$ & 10 & 26 \\
\hline 98DC-111 & Mzg & 56.5833 & 133.1500 & 5.735 & 9.57 & 7.09 & 0.09 & 7.755 & 1.52 & 0.055 & 0.57 & $<2$ & $<10$ & $<8$ & 92 \\
\hline 98DC-112 & Trhsv & 56.5833 & 133.1500 & 7.355 & 6.455 & 7.81 & 0.04 & 5.18 & 2.627 & 0.11 & 0.63 & $<2$ & $<10$ & $<8$ & 80 \\
\hline 98DC-113 & Trhsv & 56.5833 & 133.1500 & 7.71 & 5.525 & 9.06 & 2.13 & 3.675 & 2.375 & 0.05 & 0.954 & $<2$ & $<10$ & $<8$ & 5010 \\
\hline 98DC-114 & Trhv & 56.6000 & 133.1500 & 8.565 & 7.47 & 7.94 & 0.12 & 3.4 & 3.254 & 0.105 & 1.266 & $<2$ & $<10$ & $<8$ & 159 \\
\hline 98ZA-05 & Trhsv & 56.4167 & 132.9500 & 6.14 & 0.02 & 0.33 & 6.19 & 0.02 & 0.157 & 0.005 & 0.042 & $<2$ & $<10$ & $<8$ & 24430 \\
\hline 98ZA-06 & $\mathrm{Kgb}$ & 56.3667 & 132.9167 & 7.985 & 4.77 & 9.05 & 1.25 & 3.45 & 2.693 & 0.105 & 0.99 & $<2$ & $<10$ & $<8$ & 671 \\
\hline 98ZA-08 & Trhsv & 56.3667 & 132.9000 & 5.48 & 1.805 & 1.32 & 2.56 & 0.365 & 1.786 & 0.015 & 0.06 & $<2$ & $<10$ & $<8$ & 2990 \\
\hline 98ZA-10 & Trhsv & 56.2667 & 132.7000 & 8.03 & 3.2 & 4.48 & 2.85 & 1.885 & 2.769 & 0.075 & 0.72 & $<2$ & $<10$ & $<8$ & 729 \\
\hline 98ZA-11 & Trhsv & 56.2667 & 132.7000 & 4.385 & 0.01 & 1.1 & 3.16 & 0.28 & 0.181 & $<0.005$ & 0.048 & $<2$ & $<10$ & $<8$ & 4470 \\
\hline 98ZA-12 & Trhsv & 56.2667 & 132.6667 & 7.705 & 1.78 & 4.97 & 1.97 & 1.45 & 1.672 & 0.08 & 0.51 & $<2$ & $<10$ & 8 & 613 \\
\hline 98ZA-15 & Trhsv & 56.2500 & 132.7000 & 9.22 & 3.61 & 5.43 & 1.72 & 2.08 & 3.534 & 0.125 & 0.786 & $<2$ & $<10$ & $<8$ & 526 \\
\hline 98ZA-18 & Qtd & 56.2500 & 132.7500 & 8.185 & 5.095 & 8.17 & 1.33 & 2.415 & 2.385 & 0.155 & 1.332 & $<2$ & 13 & $<8$ & 814 \\
\hline 98ZA-19 & QTr & 56.2333 & 132.8000 & 6.385 & 0.11 & 0.92 & 3.44 & 0.06 & 2.651 & 0.005 & 0.06 & $<2$ & $<10$ & $<8$ & 493 \\
\hline 98ZA-20 & QTa & 56.2500 & 132.7667 & 9.315 & 3.525 & 4.85 & 1.66 & 1.25 & 3.344 & 0.085 & 0.648 & $<2$ & $<10$ & $<8$ & 527 \\
\hline 98ZA-21 & Qtd & 56.2500 & 132.7500 & 7.6 & 3.33 & 3.97 & 2.97 & 1.16 & 2.907 & 0.075 & 0.666 & $<2$ & $<10$ & $<8$ & 640 \\
\hline 98ZA-22 & Qtd & 56.2500 & 132.7500 & 6.435 & 0.185 & 0.93 & 4.16 & 0.04 & 2.389 & $<0.005$ & 0.06 & $<2$ & $<10$ & $<8$ & 189 \\
\hline 98ZA-23 & Trhsv & 56.2500 & 132.7167 & 10.4 & 2.255 & 5.95 & 2.33 & 2.57 & 2.641 & 0.085 & 0.696 & $<2$ & $<10$ & $<8$ & 1260 \\
\hline 98ZA-24 & Qtd & 56.2500 & 132.7000 & 6.925 & 0.38 & 1.44 & 3.78 & 0.045 & 3.021 & 0.005 & 0.09 & $<2$ & $<10$ & $<8$ & 559 \\
\hline ZAR\#1-01 & Trha & 56.4167 & 132.9500 & 6.46 & 0.8 & 2.25 & 4.74 & 0.525 & 0.694 & $<0.005$ & 0.06 & $<2$ & 78 & $<8$ & 1920 \\
\hline ZAR\#1-03 & Trha & 56.4167 & 132.9500 & 7.385 & 0.04 & 1.62 & 1.96 & 1.84 & 1.192 & $<0.005$ & 0.072 & $<2$ & $<10$ & $<8$ & 2520 \\
\hline ZAR\#1-12 & Trha & 56.4167 & 132.9500 & 9.765 & 1.475 & 8.28 & 1.97 & 4.175 & 1.853 & 0.25 & 0.54 & $<2$ & $<10$ & $<8$ & 183 \\
\hline ZAR\#1-15 & Trhv & 56.4167 & 132.9500 & 8.8 & 6.55 & 7.77 & 0.85 & 6.565 & 0.727 & 0.01 & 0.246 & $<2$ & 86 & $<8$ & 1230 \\
\hline ZAR\#1-17 & Trhsv & 56.4167 & 132.9500 & 6.51 & 0.385 & 2.74 & 0.61 & 1.06 & 3.32 & 0.005 & 0.078 & $<2$ & $<10$ & $<8$ & 330 \\
\hline ZAR\#1-18 & Trhsv & 56.4167 & 132.9500 & 1.365 & 26.8 & 1.21 & 0.04 & 1.08 & 0.029 & 0.04 & 0.096 & $<2$ & 16 & $<8$ & 80 \\
\hline ZAR\#1-19 & Trhsv & 56.4167 & 132.9500 & 8.66 & 1.095 & 4.82 & 2.35 & 1.77 & 1.843 & 0.045 & 0.444 & $<2$ & 11 & $<8$ & 2580 \\
\hline ZAR\#2-05 & Trha & 56.4167 & 132.9500 & 5.77 & 4.7 & 7.29 & 0.06 & 9.49 & 0.014 & 0.115 & 0.48 & $<2$ & $<10$ & $<8$ & 45 \\
\hline
\end{tabular}




\begin{tabular}{|c|c|c|c|c|c|c|c|c|c|c|c|c|c|c|c|c|}
\hline Sample \# & $\begin{array}{r}\text { C_ICP40 } \\
\text { Be } \\
\text { ppm }\end{array}$ & $\begin{array}{r}\text { C_ICP40 } \\
\text { Bi } \\
\text { ppm }\end{array}$ & $\begin{array}{r}\text { C_ICP40 } \\
\text { Cd } \\
\text { ppm }\end{array}$ & $\begin{array}{r}\text { C_ICP40 } \\
\text { Ce } \\
\text { ppm }\end{array}$ & $\begin{array}{r}\text { C_ICP40 } \\
\text { Co } \\
\text { ppm }\end{array}$ & $\begin{array}{r}\text { C_ICP40 } \\
\text { Cr } \\
\text { ppm }\end{array}$ & $\begin{array}{r}\text { C_ICP40 } \\
\text { Cu } \\
\text { ppm }\end{array}$ & $\begin{array}{r}\text { C_ICP40 } \\
\text { Eu } \\
\text { ppm }\end{array}$ & $\begin{array}{r}\text { C_ICP40 } \\
\text { Ga } \\
\text { ppm }\end{array}$ & $\begin{array}{r}\text { C_ICP40 } \\
\text { Ho } \\
\text { ppm }\end{array}$ & $\begin{array}{r}\text { C_ICP40 } \\
\text { La } \\
\text { ppm }\end{array}$ & $\begin{array}{r}\text { C_ICP40 } \\
\text { Li } \\
\text { ppm }\end{array}$ & $\begin{array}{r}\text { C_ICP40 } \\
\text { Mn } \\
\text { ppm }\end{array}$ & $\begin{array}{r}\text { C_ICP40 } \\
\text { Mo } \\
\text { ppm }\end{array}$ & $\begin{array}{r}\text { C_ICP40 } \\
\text { Nb } \\
\text { ppm }\end{array}$ & $\begin{array}{r}\text { C_ICP40 } \\
\text { Nd } \\
\text { ppm }\end{array}$ \\
\hline 98DC-78 & $<1$ & 43 & 2 & 19 & 49 & 28 & 57 & 2 & 24 & $<4$ & 6 & 11 & 1460 & $<2$ & 12 & 22 \\
\hline 98DC-79 & $<1$ & 44 & 3 & 31 & 30 & 23 & 321 & 3 & 8 & $<4$ & 9 & 16 & 1680 & $<2$ & 20 & 30 \\
\hline $98 D C-80$ & 2 & 34 & 3 & 78 & 12 & 13 & 4 & 5 & 35 & $<4$ & 31 & 8 & 1860 & 2 & 9 & 60 \\
\hline 98DC-81 & 1 & $<10$ & 5 & 9 & 12 & 128 & 1450 & $<2$ & 22 & $<4$ & 6 & $<2$ & 2460 & 5 & $<4$ & 31 \\
\hline 98DC-82 & $<1$ & 17 & $<2$ & 28 & 24 & 25 & 108 & 2 & 19 & $<4$ & 12 & 24 & 1190 & $<2$ & 15 & 26 \\
\hline $98 D C-83$ & 2 & 17 & $<2$ & 47 & 3 & 19 & 37 & $<2$ & 32 & $<4$ & 19 & 13 & 489 & $<2$ & 17 & 24 \\
\hline 98DC-84 & 1 & 18 & $<2$ & 54 & 16 & 3 & 36 & 2 & 23 & $<4$ & 26 & 14 & 402 & $<2$ & 15 & 29 \\
\hline 98DC-87 & $<1$ & 46 & 4 & 19 & 39 & 40 & 212 & 3 & 26 & $<4$ & 6 & 12 & 3130 & $<2$ & 14 & 25 \\
\hline 98DC-89 & $<1$ & $<10$ & 2 & 22 & 47 & 56 & 140 & 2 & 16 & $<4$ & 5 & 11 & 812 & $<2$ & 10 & 23 \\
\hline 98DC-91 & 2 & 20 & $<2$ & 35 & 13 & 32 & 35 & $<2$ & 27 & $<4$ & 18 & 23 & 305 & $<2$ & 9 & 27 \\
\hline 98DC-93 & $<1$ & 15 & 2 & 17 & 38 & 76 & 162 & $<2$ & 21 & $<4$ & 3 & 16 & 1150 & $<2$ & 14 & 18 \\
\hline 98DC-95 & $<1$ & 26 & 3 & 19 & 44 & 39 & 192 & 2 & 14 & $<4$ & 6 & 21 & 1030 & $<2$ & 11 & 23 \\
\hline 98DC-98 & 2 & 80 & 5 & 27 & 53 & 4 & 1310 & 3 & 20 & $<4$ & 8 & 22 & 2810 & $<2$ & 17 & 41 \\
\hline 98DC-102 & 6 & $<10$ & $<2$ & 103 & $<2$ & $<2$ & 3 & $<2$ & 28 & $<4$ & 35 & 32 & 40 & $<2$ & 56 & 27 \\
\hline 98DC-106 & 3 & $<10$ & $<2$ & 89 & $<2$ & $<2$ & 4 & $<2$ & 27 & $<4$ & 46 & 17 & $<4$ & $<2$ & 21 & 36 \\
\hline 98DC-108 & 4 & $<10$ & $<2$ & 95 & $<2$ & $<2$ & 5 & $<2$ & 23 & $<4$ & 44 & 14 & 29 & $<2$ & 22 & 37 \\
\hline 98DC-109 & 6 & $<10$ & $<2$ & 196 & $<2$ & $<2$ & 3 & $<2$ & 37 & $<4$ & 85 & 5 & 511 & $<2$ & 20 & 89 \\
\hline 98DC-111 & $<1$ & 16 & 2 & 14 & 42 & 270 & 85 & $<2$ & $<4$ & $<4$ & 6 & 61 & 1320 & $<2$ & 17 & 21 \\
\hline 98DC-112 & 1 & 20 & 2 & 32 & 33 & 148 & 97 & 2 & 10 & $<4$ & 10 & 54 & 1170 & $<2$ & 11 & 28 \\
\hline 98DC-113 & $<1$ & 41 & 4 & 24 & 38 & 66 & 124 & 3 & 20 & $<4$ & 5 & 19 & 1120 & $<2$ & 13 & 26 \\
\hline 98DC-114 & $<1$ & 31 & 2 & 30 & 38 & 163 & 283 & 3 & 15 & $<4$ & 8 & 19 & 1140 & $<2$ & 22 & 24 \\
\hline 98ZA-05 & 1 & $<10$ & 11 & 74 & $<2$ & 3 & 32 & $<2$ & 17 & $<4$ & 40 & $<2$ & $<4$ & 3 & 11 & 37 \\
\hline 98ZA-06 & 2 & 44 & 3 & 47 & 35 & 16 & 22 & 3 & 20 & $<4$ & 18 & 45 & 1350 & $<2$ & 13 & 44 \\
\hline 98ZA-08 & 2 & $<10$ & $<2$ & 71 & 3 & 8 & 28 & $<2$ & 17 & $<4$ & 36 & 11 & 219 & $<2$ & 10 & 29 \\
\hline $98 Z A-10$ & 4 & 12 & $<2$ & 57 & 17 & 11 & 22 & $<2$ & 13 & $<4$ & 26 & 35 & 688 & 4 & 17 & 28 \\
\hline 98ZA-11 & $<1$ & $<10$ & $<2$ & 21 & $<2$ & $<2$ & 30 & $<2$ & 17 & $<4$ & 13 & 21 & 55 & 3 & 8 & 12 \\
\hline 98ZA-12 & 1 & 20 & $<2$ & 36 & 12 & 17 & 49 & $<2$ & 23 & $<4$ & 18 & 32 & 578 & $<2$ & 14 & 28 \\
\hline 98ZA-15 & 2 & 51 & $<2$ & 36 & 16 & 3 & 20 & $<2$ & 21 & $<4$ & 18 & 22 & 1020 & $<2$ & 15 & 30 \\
\hline 98ZA-18 & 1 & 47 & 3 & 57 & 22 & 8 & 11 & 4 & 28 & $<4$ & 22 & 34 & 1180 & $<2$ & 14 & 44 \\
\hline 98ZA-19 & 2 & $<10$ & $<2$ & 60 & $<2$ & $<2$ & $<2$ & $<2$ & 15 & $<4$ & 32 & 8 & 113 & $<2$ & 11 & 21 \\
\hline 98ZA-20 & 2 & 13 & $<2$ & 29 & 19 & 6 & 27 & $<2$ & 25 & $<4$ & 13 & 45 & 801 & $<2$ & 16 & 22 \\
\hline 98ZA-21 & 4 & 14 & $<2$ & 60 & 13 & 15 & 3 & $<2$ & 28 & $<4$ & 27 & 20 & 572 & $<2$ & 22 & 29 \\
\hline 98ZA-22 & 3 & $<10$ & $<2$ & 93 & $<2$ & $<2$ & 2 & $<2$ & 24 & $<4$ & 48 & 15 & 91 & $<2$ & 25 & 36 \\
\hline 98ZA-23 & 2 & $<10$ & $<2$ & 29 & 19 & 6 & 7 & $<2$ & 20 & $<4$ & 11 & 59 & 909 & $<2$ & 17 & 23 \\
\hline 98ZA-24 & 2 & $<10$ & $<2$ & 90 & $<2$ & $<2$ & 14 & $<2$ & 23 & $<4$ & 44 & 6 & 88 & $<2$ & 24 & 36 \\
\hline ZAR\#1-01 & 1 & $<10$ & $<2$ & 93 & $<2$ & $<2$ & 14 & $<2$ & 25 & $<4$ & 46 & 16 & 245 & 5 & 13 & 43 \\
\hline ZAR\#1-03 & 4 & $<10$ & $<2$ & 89 & $<2$ & $<2$ & 21 & $<2$ & 28 & $<4$ & 44 & 25 & 101 & $<2$ & 14 & 43 \\
\hline ZAR\#1-12 & 1 & 19 & 2 & 37 & 33 & 34 & 159 & 3 & 16 & $<4$ & 13 & 43 & 689 & $<2$ & 15 & 42 \\
\hline ZAR\#1-15 & $<1$ & 15 & $<2$ & $<5$ & 70 & 73 & 72 & $<2$ & $<4$ & $<4$ & $<2$ & 53 & 1320 & $<2$ & 16 & $<9$ \\
\hline ZAR\#1-17 & 1 & $<10$ & $<2$ & 81 & $<2$ & $<2$ & 6 & $<2$ & 30 & $<4$ & 42 & 13 & 355 & $<2$ & 7 & 34 \\
\hline ZAR\#1-18 & $<1$ & $<10$ & $<2$ & 9 & 5 & 6 & 24 & $<2$ & 6 & $<4$ & 4 & 7 & 600 & $<2$ & $<4$ & $<9$ \\
\hline ZAR\#1-19 & 2 & 10 & $<2$ & 39 & 21 & 7 & 100 & $<2$ & 18 & $<4$ & 19 & 21 & 915 & $<2$ & 12 & 30 \\
\hline ZAR\#2-05 & $<1$ & 19 & 2 & 23 & 46 & 359 & 108 & 2 & $<4$ & $<4$ & 10 & 26 & 1020 & $<2$ & 15 & 27 \\
\hline
\end{tabular}




\begin{tabular}{|c|c|c|c|c|c|c|c|c|c|c|c|c|c|c|}
\hline Sample \# & $\begin{array}{r}\text { C_ICP40 } \\
\mathrm{Ni}\end{array}$ & $\begin{array}{r}\text { C_ICP40 } \\
\text { Pb }\end{array}$ & $\begin{array}{r}\text { C_ICP40 } \\
\text { Sc }\end{array}$ & $\begin{array}{r}\text { C_ICP40 } \\
\text { Sn }\end{array}$ & $\begin{array}{r}\text { C_ICP40 } \\
\mathrm{Sr}\end{array}$ & $\begin{array}{r}\text { C_ICP40 } \\
\text { Ta }\end{array}$ & $\begin{array}{r}\text { C_ICP40 } \\
\text { Th }\end{array}$ & $\begin{array}{r}\text { C_ICP40 } \\
\text { U }\end{array}$ & $\begin{array}{r}\text { C_ICP40 } \\
\text { V }\end{array}$ & $\begin{array}{r}\text { C_ICP40 } \\
Y\end{array}$ & $\begin{array}{r}\text { C_ICP40 } \\
\text { Yb }\end{array}$ & $\begin{array}{r}\text { C_ICP40 } \\
\text { Zn }\end{array}$ & $\begin{array}{r}\mathrm{C}+\mathrm{CO} 2 \mathrm{C} \\
\mathrm{CO} 2\end{array}$ & $\begin{array}{l}\text { C_CO2 C } \\
\text { CRBNT C }\end{array}$ \\
\hline & $\mathrm{ppm}$ & ppm & ppm & ppm & ppm & $\mathrm{ppm}$ & ppm & ppm & ppm & ppm & ppm & ppm & $\%$ & $\%$ \\
\hline 98DC-78 & 58 & $<4$ & 46 & $<5$ & 59 & $<40$ & $<6$ & $<100$ & 294 & 24 & 3 & 96 & 1 & 0.27 \\
\hline 98DC-79 & 35 & $<4$ & 41 & $<5$ & 574 & $<40$ & $<6$ & $<100$ & 426 & 33 & 4 & 102 & 0.25 & 0.07 \\
\hline 98DC-80 & $<3$ & 5 & 22 & $<5$ & 369 & $<40$ & $<6$ & $<100$ & 33 & 56 & 5 & 162 & 4.61 & 1.26 \\
\hline 98DC-81 & 33 & $<4$ & $<2$ & $<5$ & 209 & $<40$ & $<6$ & $<100$ & 128 & 19 & 2 & 22 & 12.7 & 3.47 \\
\hline 98DC-82 & 27 & $<4$ & 23 & $<5$ & 126 & $<40$ & $<6$ & $<100$ & 278 & 14 & 3 & 81 & 5.79 & 1.58 \\
\hline 98DC-83 & 42 & $<4$ & 17 & $<5$ & 850 & $<40$ & 7 & $<100$ & 185 & 17 & 3 & 39 & 0.24 & 0.07 \\
\hline 98DC-84 & 10 & $<4$ & 14 & $<5$ & 603 & $<40$ & $<6$ & $<100$ & 192 & 18 & 3 & 31 & 2.55 & 0.7 \\
\hline 98DC-87 & 54 & 11 & 40 & $<5$ & 255 & $<40$ & $<6$ & $<100$ & 401 & 28 & 4 & 193 & 3.41 & 0.93 \\
\hline 98DC-89 & 65 & $<4$ & 45 & $<5$ & 125 & $<40$ & $<6$ & $<100$ & 176 & 25 & 3 & 106 & 1.87 & 0.51 \\
\hline 98DC-91 & 31 & $<4$ & 13 & $<5$ & 385 & $<40$ & $<6$ & $<100$ & 135 & 13 & 2 & 105 & 0.52 & 0.14 \\
\hline 98DC-93 & 80 & $<4$ & 49 & $<5$ & 210 & $<40$ & $<6$ & $<100$ & 304 & 20 & 3 & 66 & 0.21 & 0.06 \\
\hline 98DC-95 & 64 & $<4$ & 41 & $<5$ & 256 & $<40$ & $<6$ & $<100$ & 310 & 29 & 3 & 114 & 3.63 & 0.99 \\
\hline 98DC-98 & 7 & 12 & 60 & $<5$ & 104 & $<40$ & $<6$ & $<100$ & 503 & 36 & 4 & 299 & 7.68 & 2.1 \\
\hline 98DC-102 & $<3$ & 25 & $<2$ & 8 & 4 & $<40$ & 18 & $<100$ & 2 & 30 & 4 & 148 & 0.02 & 0.01 \\
\hline 98DC-106 & $<3$ & 14 & $<2$ & $<5$ & 31 & $<40$ & 20 & $<100$ & 6 & 35 & 3 & 70 & 0.02 & 0.01 \\
\hline 98DC-108 & 3 & 4 & $<2$ & $<5$ & 19 & $<40$ & 17 & $<100$ & 2 & 30 & 3 & 34 & 0.02 & 0.01 \\
\hline 98DC-109 & $<3$ & 29 & $<2$ & 5 & 3 & $<40$ & 20 & $<100$ & 5 & 28 & 3 & 221 & 0.02 & 0.01 \\
\hline 98DC-111 & 88 & $<4$ & 63 & $<5$ & 255 & $<40$ & $<6$ & $<100$ & 284 & 13 & 2 & 48 & 0.27 & 0.07 \\
\hline 98DC-112 & 56 & $<4$ & 47 & $<5$ & 571 & $<40$ & $<6$ & $<100$ & 313 & 15 & 2 & 82 & 2.97 & 0.81 \\
\hline 98DC-113 & 58 & $<4$ & 44 & $<5$ & 267 & $<40$ & $<6$ & $<100$ & 309 & 27 & 3 & 93 & 0.9 & 0.25 \\
\hline 98DC-114 & 80 & $<4$ & 39 & $<5$ & 254 & $<40$ & $<6$ & $<100$ & 351 & 32 & 4 & 852 & 4.09 & 1.12 \\
\hline 98ZA-05 & 4 & 2520 & $<2$ & $<5$ & 71 & $<40$ & 8 & $<100$ & 6 & 5 & $<1$ & 1820 & 0.02 & 0.01 \\
\hline 98ZA-06 & 30 & 6 & 32 & $<5$ & 376 & $<40$ & $<6$ & $<100$ & 152 & 32 & 3 & 122 & 0.11 & 0.03 \\
\hline 98ZA-08 & 3 & 44 & $<2$ & $<5$ & 191 & $<40$ & 10 & $<100$ & 9 & 32 & 3 & 237 & 1.61 & 0.44 \\
\hline $98 Z A-10$ & 22 & 26 & 14 & $<5$ & 222 & $<40$ & 8 & $<100$ & 111 & 23 & 3 & 70 & 1.49 & 0.41 \\
\hline 98ZA-11 & $<3$ & 8 & $<2$ & $<5$ & 46 & $<40$ & $<6$ & $<100$ & 2 & 13 & 2 & 37 & $<0.01$ & $<0.003$ \\
\hline 98ZA-12 & 30 & 5 & 15 & $<5$ & 170 & $<40$ & $<6$ & $<100$ & 177 & 18 & 3 & 104 & $<0.01$ & $<0.003$ \\
\hline 98ZA-15 & 5 & $<4$ & 17 & $<5$ & 472 & $<40$ & $<6$ & $<100$ & 161 & 26 & 4 & 100 & 0.16 & 0.04 \\
\hline 98ZA-18 & $<3$ & $<4$ & 27 & $<5$ & 500 & $<40$ & $<6$ & $<100$ & 215 & 28 & 3 & 127 & 0.05 & 0.01 \\
\hline 98ZA-19 & $<3$ & 17 & $<2$ & 6 & 61 & $<40$ & 18 & $<100$ & 4 & 15 & 2 & 27 & $<0.01$ & $<0.003$ \\
\hline 98ZA-20 & 23 & $<4$ & 12 & $<5$ & 537 & $<40$ & $<6$ & $<100$ & 130 & 14 & 2 & 89 & 2.77 & 0.76 \\
\hline 98ZA-21 & 11 & 7 & 12 & $<5$ & 248 & $<40$ & 8 & $<100$ & 101 & 24 & 3 & 60 & 2.48 & 0.68 \\
\hline 98ZA-22 & $<3$ & 7 & $<2$ & $<5$ & 38 & $<40$ & 22 & $<100$ & 3 & 38 & 3 & 19 & $<0.01$ & $<0.003$ \\
\hline 98ZA-23 & 10 & 5 & 20 & $<5$ & 438 & $<40$ & $<6$ & $<100$ & 194 & 19 & 3 & 111 & 0.07 & 0.02 \\
\hline 98ZA-24 & $<3$ & 11 & $<2$ & $<5$ & 66 & $<40$ & 12 & $<100$ & 7 & 28 & 2 & 32 & 0.01 & $<0.003$ \\
\hline ZAR\#1-01 & $<3$ & 8 & $<2$ & $<5$ & 76 & $<40$ & 10 & $<100$ & 4 & 28 & 3 & 164 & 0.87 & 0.24 \\
\hline ZAR\#1-03 & $<3$ & 18 & $<2$ & $<5$ & 86 & $<40$ & 10 & $<100$ & $<2$ & 48 & 5 & 170 & 0.02 & 0.01 \\
\hline ZAR\#1-12 & 12 & $<4$ & 34 & $<5$ & 101 & $<40$ & $<6$ & $<100$ & 361 & 14 & 2 & 95 & 0.97 & 0.26 \\
\hline ZAR\#1-15 & 221 & $<4$ & 42 & $<5$ & 242 & $<40$ & $<6$ & $<100$ & 234 & 12 & 2 & 93 & 1.03 & 0.28 \\
\hline ZAR\#1-17 & 4 & 15 & $<2$ & $<5$ & 111 & $<40$ & 9 & $<100$ & 5 & 12 & 2 & 291 & 0.39 & 0.11 \\
\hline ZAR\#1-18 & 14 & 12 & 2 & $<5$ & 360 & $<40$ & $<6$ & $<100$ & 42 & 10 & $<1$ & 37 & 12.6 & 3.44 \\
\hline ZAR\#1-19 & 39 & 20 & 17 & $<5$ & 172 & $<40$ & 6 & $<100$ & 160 & 17 & 3 & 102 & 0.65 & 0.18 \\
\hline ZAR\#2-05 & 304 & $<4$ & 33 & $<5$ & 156 & $<40$ & $<6$ & $<100$ & 251 & 12 & 2 & 51 & 4.92 & 1.34 \\
\hline
\end{tabular}




\begin{tabular}{|c|c|c|c|c|}
\hline Sample \# & Location & Rock type & Description & Age \\
\hline ZAR\#2-09 & Frenchie, $\left(215^{\prime}\right)$ & greenstone & massive, chloritic, weakly veined greenstone & Triassic(?) \\
\hline ZAR\#2-10 & Frenchie, (241') & greenstone & massive, chloritic, weakly veined greenstone & Triassic(?) \\
\hline ZAR\#2-11 & Frenchie, (267') & gabbro & greenstone, coarse grained, possible gabbro & Triassic (?) \\
\hline ZAR\#2-12 & Frenchie, (288') & gabbro & greenstone, coarse grained, possible gabbro & Triassic (?) \\
\hline ZAR\#2-14 & Frenchie, (317') & feldspar crystal tuff & green to white feldspar crystal tuff & Triassic(?) \\
\hline ZAR\#2-16 & Frenchie, $\left(334.5^{\prime}\right)$ & siliceous tuff & green-white siliceous tuff & Triassic(?) \\
\hline ZAR\#2-17 & Frenchie, (337') & lapilli tuff & dark green squashed lapilli tuff & Triassic(?) \\
\hline ZAR\#2-20 & Frenchie, $\left(389^{\prime}\right)$ & chl phyllite & medium green finely foliated chloritic tuff & Triassic(?) \\
\hline ZAR\#2-21 & Frenchie, (433') & greenstone & slightly blocky, volcaniclastic textured greenstone & Triassic(?) \\
\hline ZAR\#2-22 & Frenchie, $\left(450^{\prime}\right)$ & mafic dike & black, siliceous, mafic dike & Tertiary-Quaternary \\
\hline ZAR\#2-23 & Frenchie, (467') & greenstone & possibly a gabbro adjacent to the dike & Triassic (?) \\
\hline ZAR\#2-25 & Frenchie, (488') & greenstone & volcaniclastic mafic rock & Triassic(?) \\
\hline 98ET-01 & Quiet Harbor, Etolin Island & alkalai granite & alkalai granite from creek bank & Tertiary \\
\hline 98ET-02 & Island NE of Steamer Point & felsic volcanic & bleached, fine-bedded fragmental volcanic & Tertiary-Quaternary \\
\hline 98ET-03 & west side Kindergarten bay & rhyolite & fresh, jointed, non-foliated & Tertiary-Quaternary \\
\hline 98ET-04 & west side Kindergarten bay & rhyolite & fresh, jointed, non-foliated & Tertiary-Quaternary \\
\hline 98ET-05 & Steamer Bay, east shore & basalt & volcaniclastics and flows; sample from massive flow & Jurassic-Cretaceous \\
\hline 98ET-06 & Steamer Bay, east shore & basalt & volcaniclastics and flows; sample from massive flow & Jurassic-Cretaceous \\
\hline 98ET-07 & Steamer Bay, east shore & basalt & massive flow or sill & Jurassic-Cretaceous \\
\hline 98ET-08 & Steamer Bay, east shore & basalt & sequence of fresh, $1.2 \mathrm{~m}$ thick flows, massive to vesicular & Jurassic-Cretaceous \\
\hline 98ET-09 & Steamer Bay, east shore & basalt & set of massive flows over a pillowed plow, aph & Jurassic-Cretaceous \\
\hline 98ET-10 & Steamer Bay, east shore & microgabbro & blocky, micro-porph mafic rock & Jurassic-Cretaceous \\
\hline 98ET-11 & Steamer Bay, east shore & basalt & massive, vesicular & Jurassic-Cretaceous \\
\hline 98ET-12 & Steamer Bay, east shore & basalt & massive, vesicular, blocky, aph & Jurassic-Cretaceous \\
\hline 98ET-13 & Steamer Bay, east shore & basalt & massive, vesicular, blocky, aph & Jurassic-Cretaceous \\
\hline 98ET-14 & Steamer Bay, west shore & basalt & thin massive flow of pyroxene-porph basalt & Jurassic-Cretaceous \\
\hline 98ET-15 & Steamer Bay, west shore & basalt & pyroxene-porph basalt, slightly hematitic & Jurassic-Cretaceous \\
\hline 98ET-16 & Steamer Bay, west shore & basalt & volcaniclastics and aph flows; sample from volcaniclastics & Jurassic-Cretaceous \\
\hline 98ET-17 & Steamer Bay, west shore & basalt & aph, with 2-3 mm vesicles & Jurassic-Cretaceous \\
\hline 98ET-18 & Steamer Bay, east side of Pt. Herrington & basalt & massive, vesicular, aph basalt & Jurassic-Cretaceous \\
\hline 98ET-19 & Observation Island south tip & basalt & massive aph basalt & Jurassic-Cretaceous \\
\hline 98ET-20 & west side of Pt. Herrington Pn. & basalt & coarse pyroxene-porph basalt & Jurassic-Cretaceous \\
\hline 98ET-21 & Marsh Island north end & basaltic dike & augite-porph dike crosscutting Gravina sediments & Jurassic-Cretaceous \\
\hline 98SK009A & Southwest side of Bohemia Range & granodiorite & foliated granodiorite & Cretaceous \\
\hline 98SK012A & Southwest side of Bohemia Range & basalt & 50 meter dike & Tertiary \\
\hline 98SK015A & East side of Bohemia Range & granitic & foliated felsic intrusive rock & Cretaceous \\
\hline 98SK039B & Southwest side of Bohemia Range & greenstone & mafic sill & Permian \\
\hline 98SK040A & North of Hamilton Creek & felsite & massive perthitic felsite & Tertiary \\
\hline 98SK043A & North of Castle River & basalt & 10 meter dike & Tertiary \\
\hline 98SK047A & North of Castle River & basalt & dike & Tertiary \\
\hline 98SK054A & North of Castle River & greenstone & plagioclase porphyritic, foliated & Devonian \\
\hline 98SK058A & Southwest of Towers Lake & gabbro & massive, homogenous, fine-grained & Tertiary \\
\hline 98SK060A & Keyhole Lake rock pit & chert & black radiolarian chert, bedded & Mississippian \\
\hline
\end{tabular}




\begin{tabular}{|c|c|c|c|c|c|c|c|c|c|c|c|c|c|c|c|}
\hline Sample \# & Unit & DD Lat & DD Long & $\begin{array}{r}\text { C_ICP40 } \\
\text { Al } \\
\% \\
\end{array}$ & $\begin{array}{r}\text { C_ICP40 } \\
\mathrm{Ca} \\
\% \\
\end{array}$ & $\begin{array}{r}\text { C_ICP40 } \\
\text { Fe } \\
\% \\
\end{array}$ & $\begin{array}{r}\text { C_ICP40 } \\
\text { K } \\
\% \\
\end{array}$ & $\begin{array}{r}\text { C_ICP40 } \\
\text { Mg } \\
\% \\
\end{array}$ & $\begin{array}{r}\text { C_ICP40 } \\
\mathrm{Na} \\
\% \\
\end{array}$ & $\begin{array}{r}\text { C_ICP40 } \\
\text { P } \\
\% \\
\end{array}$ & $\begin{array}{r}\text { C_ICP40 } \\
\text { Ti } \\
\% \\
\end{array}$ & $\begin{array}{r}\text { C_ICP40 } \\
\text { Ag } \\
\text { ppm } \\
\end{array}$ & $\begin{array}{r}\text { C_ICP40 } \\
\text { As } \\
\text { ppm } \\
\end{array}$ & $\begin{array}{r}\text { C_ICP40 } \\
\text { Au } \\
\text { ppm } \\
\end{array}$ & $\begin{array}{r}\text { C_ICP40 } \\
\text { Ba } \\
\text { ppm } \\
\end{array}$ \\
\hline ZAR\#2-09 & Trhv & 56.4167 & 132.9500 & 8.55 & 6.195 & 7.84 & 0.66 & 5.32 & 1.962 & 0.015 & 0.306 & $<2$ & $<10$ & $<8$ & 486 \\
\hline ZAR\#2-10 & Trhv & 56.4167 & 132.9500 & 8.4 & 7.05 & 8.15 & 0.18 & 4.74 & 1.61 & 0.015 & 0.27 & $<2$ & 16 & $<8$ & 141 \\
\hline ZAR\#2-11 & Mzg & 56.4167 & 132.9500 & 7.245 & 7.475 & 8.03 & 0.14 & 4.865 & 1.487 & 0.015 & 0.27 & $<2$ & $<10$ & $<8$ & 95 \\
\hline ZAR\#2-12 & Mzg & 56.4167 & 132.9500 & 8.18 & 7.995 & 7.92 & 0.28 & 5.025 & 1.316 & 0.015 & 0.258 & $<2$ & $<10$ & $<8$ & 196 \\
\hline ZAR\#2-14 & Trhsv & 56.4167 & 132.9500 & 0.64 & $<0.005$ & 0.51 & 0.02 & 0.415 & 0.01 & 0.03 & 0.042 & $<2$ & $<10$ & $<8$ & 10 \\
\hline ZAR\#2-16 & Trhsv & 56.4167 & 132.9500 & 5.65 & 0.21 & 2.08 & 0.96 & 0.49 & 2.836 & $<0.005$ & 0.042 & $<2$ & $<10$ & $<8$ & 784 \\
\hline ZAR\#2-17 & Trhsv & 56.4167 & 132.9500 & 6.87 & 0.158 & 4.55 & 1.04 & 1.18 & 2.67 & 0.02 & 0.138 & $<2$ & $<10$ & 9 & 775 \\
\hline ZAR\#2-20 & Trhsv & 56.4167 & 132.9500 & 6.705 & 1.108 & 5.66 & 1.66 & 1.93 & 1.824 & 0.045 & 0.339 & $<2$ & $<10$ & $<8$ & 1580 \\
\hline ZAR\#2-21 & Trhsv & 56.4167 & 132.9500 & 8.32 & 5.481 & 8.05 & 0.77 & 3.335 & 3.116 & 0.25 & 0.811 & $<2$ & 25 & $<8$ & 1190 \\
\hline ZAR\#2-22 & Qtd & 56.4167 & 132.9500 & 8.875 & 4.552 & 6.62 & 0.07 & 2.6 & 3.957 & 0.17 & 0.558 & $<2$ & $<10$ & $<8$ & 102 \\
\hline ZAR\#2-23 & Mzg & 56.4167 & 132.9500 & 8.27 & 5.476 & 6.55 & 2.56 & 5.73 & 1.064 & 0.015 & 0.247 & $<2$ & 28 & $<8$ & 1510 \\
\hline ZAR\#2-25 & Trhsv & 56.4167 & 132.9500 & 7.605 & 5.896 & 8.57 & 0.58 & 2.89 & 1.382 & 0.2 & 2.133 & $<2$ & 11 & $<8$ & 288 \\
\hline 98ET-01 & Tmaz & 56.2167 & 132.6500 & 6.475 & 0.215 & 1.27 & 4.14 & 0.02 & 2.613 & $<0.005$ & 0.058 & $<2$ & 29 & $<8$ & 56 \\
\hline 98ET-02 & QTr & 56.2333 & 132.6833 & 1.99 & 2.457 & 1.73 & 0.75 & 0.51 & 0.637 & 0.025 & 0.121 & $<2$ & $<10$ & $<8$ & 475 \\
\hline 98ET-03 & QTr & 56.1833 & 132.6833 & 7.765 & 0.635 & 1.42 & 2.15 & 0.165 & 3.254 & 0.035 & 0.052 & $<2$ & $<10$ & $<8$ & 851 \\
\hline 98ET-04 & QTr & 56.1833 & 132.7000 & 7.615 & 1.187 & 1.45 & 2.24 & 0.145 & 2.95 & 0.03 & 0.046 & $<2$ & $<10$ & $<8$ & 973 \\
\hline 98ET-05 & KJsv & 56.1833 & 132.7000 & 8.985 & 2.961 & 6.41 & 2.35 & 4.835 & 1.848 & 0.04 & 0.472 & $<2$ & $<10$ & $<8$ & 366 \\
\hline 98ET-06 & KJsv & 56.1833 & 132.7000 & 10.1 & 5.266 & 5.71 & 0.71 & 2.44 & 2.708 & 0.065 & 0.454 & $<2$ & $<10$ & $<8$ & 563 \\
\hline 98ET-07 & KJsv & 56.1667 & 132.6833 & 8.695 & 5.392 & 5.95 & 1.45 & 2.8 & 2.503 & 0.13 & 0.874 & $<2$ & 12 & $<8$ & 516 \\
\hline 98ET-08 & KJsv & 56.1667 & 132.6833 & 10.2 & 3.686 & 4.96 & 1.24 & 1.55 & 2.446 & 0.05 & 0.322 & $<2$ & $<10$ & 10 & 287 \\
\hline 98ET-09 & KJsv & 56.1667 & 132.6833 & 9.735 & 3.665 & 5.75 & 1.92 & 1.305 & 2.1 & 0.08 & 0.403 & $<2$ & $<10$ & $<8$ & 778 \\
\hline 98ET-10 & KJsv & 56.1667 & 132.6833 & 10.7 & 7.172 & 7.02 & 0.23 & 1.755 & 2.484 & 0.045 & 0.529 & $<2$ & $<10$ & $<8$ & 154 \\
\hline 98ET-11 & KJsv & 56.1500 & 132.6833 & 9.69 & 8.474 & 7.76 & 0.19 & 2.805 & 1.506 & 0.03 & 0.523 & $<2$ & $<10$ & $<8$ & 152 \\
\hline 98ET-12 & KJsv & 56.1500 & 132.6667 & 9.53 & 4.279 & 5.18 & 0.99 & 1.86 & 3.126 & 0.065 & 0.374 & $<2$ & $<10$ & $<8$ & 673 \\
\hline 98ET-13 & KJsv & 56.1500 & 132.6667 & 9.35 & 6.725 & 7.04 & 0.61 & 3.28 & 2.119 & 0.04 & 0.546 & $<2$ & 11 & $<8$ & 282 \\
\hline 98ET-14 & KJsv & 56.1333 & 132.6667 & 9.01 & 7.056 & 6.82 & 0.6 & 4.665 & 2.166 & 0.065 & 0.512 & $<2$ & $<10$ & $<8$ & 284 \\
\hline 98ET-15 & KJsv & 56.1500 & 132.6833 & 7.325 & 7.954 & 6.27 & 0.27 & 5.71 & 1.492 & 0.02 & 0.403 & $<2$ & $<10$ & 9 & 86 \\
\hline 98ET-16 & KJsv & 56.1500 & 132.7000 & 9.175 & 6.269 & 6.79 & 0.66 & 2.26 & 1.753 & 0.06 & 0.615 & $<2$ & $<10$ & $<8$ & 414 \\
\hline 98ET-17 & KJsv & 56.1500 & 132.7000 & 10 & 4.494 & 6.06 & 0.58 & 2.315 & 3.164 & 0.07 & 0.61 & $<2$ & $<10$ & $<8$ & 419 \\
\hline 98ET-18 & KJsv & 56.1667 & 132.7167 & 9.74 & 5.67 & 7.69 & 1.41 & 2.71 & 2.836 & 0.07 & 0.633 & $<2$ & $<10$ & $<8$ & 756 \\
\hline 98ET-19 & KJsv & 56.1500 & 132.7167 & 9.375 & 7.061 & 6.93 & 0.64 & 3.155 & 2.09 & 0.055 & 0.518 & $<2$ & $<10$ & $<8$ & 357 \\
\hline 98ET-20 & KJsv & 56.1333 & 132.7167 & 8.035 & 7.917 & 6.54 & 0.41 & 5.395 & 2.038 & 0.035 & 0.42 & $<2$ & $<10$ & $<8$ & 168 \\
\hline 98ET-21 & KJsv & 56.1167 & 132.7000 & 8.765 & 7.628 & 6.56 & 0.28 & 4.445 & 1.544 & 0.04 & 0.477 & $<2$ & $<10$ & $<8$ & 405 \\
\hline 98SK009A & $\mathrm{Ki}$ & 56.9508 & 133.4875 & 8.775 & 2.536 & 1.24 & 1.56 & 0.315 & 3.268 & 0.03 & 0.104 & $<2$ & $<10$ & $<8$ & 722 \\
\hline 98SK012A & QTd & 56.9450 & 133.4764 & 7.485 & 6.395 & 9.47 & 0.84 & 2.83 & 2.489 & 0.265 & 2.231 & $<2$ & 15 & $<8$ & 621 \\
\hline 98SK015A & $\mathrm{Ki}$ & 56.9611 & 133.3922 & 9.415 & 2.289 & 1.83 & 1.3 & 0.98 & 4.555 & 0.04 & 0.155 & $<2$ & $<10$ & $<8$ & 747 \\
\hline 98SK039B & PMc & 56.9272 & 133.4861 & 8.345 & 7.229 & 8.04 & 0.17 & 3.255 & 2.731 & 0.06 & 0.974 & $<2$ & $<10$ & $<8$ & 150 \\
\hline 98SK040A & $Q T r$ & 56.9294 & 133.5486 & 6.73 & 0.021 & 1.08 & 3.88 & 0.035 & 2.256 & $<0.005$ & 0.058 & $<2$ & $<10$ & $<8$ & 817 \\
\hline 98SK043A & QTd & 56.6639 & 133.5869 & 7.88 & 5.045 & 7.69 & 1.26 & 2.155 & 2.812 & 0.185 & 1.357 & $<2$ & 12 & $<8$ & 667 \\
\hline 98SK047A & QTd & 56.6694 & 133.2592 & 7.735 & 4.505 & 7.82 & 1.6 & 1.86 & 2.822 & 0.22 & 1.461 & $<2$ & 14 & $<8$ & 1110 \\
\hline 98SK054A & Dsv & 56.6889 & 133.2347 & 7.225 & 4.967 & 9.75 & 0.89 & 3.18 & 2.033 & 0.09 & 1.478 & $<2$ & 12 & $<8$ & 1120 \\
\hline 98SK058A & Tmgb & 56.8306 & 133.5583 & 7.01 & 6.074 & 9.29 & 1.14 & 2.88 & 2.389 & 0.615 & 1.984 & $<2$ & 17 & $<8$ & 1010 \\
\hline 98SK060A & PMc & 56.9194 & 133.6333 & 1.34 & 0.903 & 0.89 & 0.54 & 0.43 & 0.019 & 0.015 & 0.104 & $<2$ & $<10$ & $<8$ & 409 \\
\hline
\end{tabular}




\begin{tabular}{|c|c|c|c|c|c|c|c|c|c|c|c|c|c|c|c|c|}
\hline Sample \# & $\begin{array}{r}\text { C_ICP40 } \\
\text { Be } \\
\text { ppm }\end{array}$ & $\begin{array}{r}\text { C_ICP40 } \\
\text { Bi } \\
\text { ppm }\end{array}$ & $\begin{array}{r}\text { C_ICP40 } \\
\text { Cd } \\
\text { ppm }\end{array}$ & $\begin{array}{r}\text { C_ICP40 } \\
\text { Ce } \\
\text { ppm }\end{array}$ & $\begin{array}{r}\text { C_ICP40 } \\
\text { Co } \\
\text { ppm }\end{array}$ & $\begin{array}{r}\text { C_ICP40 } \\
\text { Cr } \\
\text { ppm }\end{array}$ & $\begin{array}{r}\text { C_ICP40 } \\
\text { Cu } \\
\text { ppm }\end{array}$ & $\begin{array}{r}\text { C_ICP40 } \\
\text { Eu } \\
\text { ppm }\end{array}$ & $\begin{array}{r}\text { C_ICP40 } \\
\text { Ga } \\
\text { ppm }\end{array}$ & $\begin{array}{r}\text { C_ICP40 } \\
\text { Ho } \\
\text { ppm }\end{array}$ & $\begin{array}{r}\text { C_ICP40 } \\
\text { La } \\
\text { ppm }\end{array}$ & $\begin{array}{r}\text { C_ICP40 } \\
\text { Li } \\
\text { ppm }\end{array}$ & $\begin{array}{r}\text { C_ICP40 } \\
\text { Mn } \\
\text { ppm }\end{array}$ & $\begin{array}{r}\text { C_ICP40 } \\
\text { Mo } \\
\text { ppm }\end{array}$ & $\begin{array}{r}\text { C_ICP40 } \\
\text { Nb } \\
\text { ppm }\end{array}$ & $\begin{array}{r}\text { C_ICP40 } \\
\text { Nd } \\
\text { ppm }\end{array}$ \\
\hline ZAR\#2-09 & $<1$ & 11 & 3 & $<5$ & 47 & 58 & 166 & $<2$ & 8 & $<4$ & $<2$ & 20 & 896 & $<2$ & 12 & 11 \\
\hline ZAR\#2-10 & $<1$ & 12 & 3 & $<5$ & 50 & 53 & 159 & $<2$ & 6 & $<4$ & $<2$ & 17 & 1180 & $<2$ & 14 & 12 \\
\hline ZAR\#2-11 & $<1$ & 11 & 2 & $<5$ & 45 & 111 & 165 & $<2$ & 13 & $<4$ & $<2$ & 13 & 1250 & $<2$ & 13 & 10 \\
\hline ZAR\#2-12 & $<1$ & 12 & 2 & $<5$ & 44 & 128 & 172 & $<2$ & 17 & $<4$ & $<2$ & 14 & 1170 & $<2$ & 15 & $<9$ \\
\hline ZAR\#2-14 & $<1$ & $<10$ & $<2$ & 5 & 4 & $<2$ & 10 & $<2$ & $<4$ & $<4$ & $<2$ & $<2$ & 679 & $<2$ & $<4$ & $<9$ \\
\hline ZAR\#2-16 & 1 & $<10$ & $<2$ & 58 & $<2$ & $<2$ & 14 & $<2$ & 24 & $<4$ & 28 & 9 & 282 & 21 & 5 & 26 \\
\hline ZAR\#2-17 & 1 & $<10$ & $<2$ & 53 & $<2$ & $<2$ & 10 & $<2$ & 26 & $<4$ & 25 & 26 & 519 & 3 & 10 & 32 \\
\hline ZAR\#2-20 & 2 & 11 & $<2$ & 61 & $<2$ & $<2$ & 14 & 3 & 17 & $<4$ & 30 & 25 & 955 & $<2$ & 10 & 40 \\
\hline ZAR\#2-21 & 1 & 10 & 3 & 46 & 28 & 3 & 110 & 3 & 10 & $<4$ & 15 & 15 & 1230 & $<2$ & 15 & 38 \\
\hline ZAR\#2-22 & 1 & 20 & $<2$ & 47 & 20 & 7 & 203 & 2 & 17 & $<4$ & 21 & 22 & 969 & $<2$ & 12 & 34 \\
\hline ZAR\#2-23 & $<1$ & 11 & 3 & 6 & 41 & 164 & 48 & $<2$ & 7 & $<4$ & $<2$ & 34 & 1060 & $<2$ & 16 & 12 \\
\hline ZAR\#2-25 & 1 & 47 & 3 & 51 & 27 & 46 & 28 & 3 & 14 & $<4$ & 18 & 41 & 1620 & $<2$ & 23 & 37 \\
\hline 98ET-01 & 5 & $<10$ & $<2$ & 133 & $<2$ & $<2$ & $<2$ & $<2$ & 30 & $<4$ & 67 & 8 & 116 & $<2$ & 32 & 56 \\
\hline 98ET-02 & $<1$ & $<10$ & $<2$ & 13 & $<2$ & 3 & 10 & $<2$ & 11 & $<4$ & 4 & 20 & 152 & $<2$ & $<4$ & $<9$ \\
\hline 98ET-03 & 2 & $<10$ & $<2$ & 49 & $<2$ & $<2$ & $<2$ & $<2$ & 20 & $<4$ & 26 & 10 & 377 & $<2$ & 14 & 14 \\
\hline 98ET-04 & 2 & $<10$ & $<2$ & 50 & $<2$ & $<2$ & $<2$ & $<2$ & 21 & $<4$ & 25 & 11 & 308 & $<2$ & 13 & 12 \\
\hline 98ET-05 & $<1$ & 14 & $<2$ & 14 & 27 & 25 & 109 & $<2$ & 9 & $<4$ & 4 & 54 & 743 & $<2$ & 14 & 17 \\
\hline 98ET-06 & $<1$ & 14 & $<2$ & 18 & 17 & $<2$ & 121 & $<2$ & 19 & $<4$ & 6 & 26 & 1140 & $<2$ & 17 & 17 \\
\hline 98ET-07 & 1 & 25 & $<2$ & 59 & 22 & 26 & 19 & $<2$ & 15 & $<4$ & 25 & 21 & 996 & $<2$ & 23 & 32 \\
\hline 98ET-08 & $<1$ & $<10$ & $<2$ & 18 & 16 & 7 & 85 & $<2$ & 15 & $<4$ & 6 & 21 & 572 & $<2$ & 9 & 15 \\
\hline 98ET-09 & 2 & 11 & $<2$ & 33 & 14 & $<2$ & 35 & $<2$ & 24 & $<4$ & 12 & 15 & 1170 & $<2$ & 14 & 20 \\
\hline 98ET-10 & $<1$ & 35 & 2 & 14 & 24 & $<2$ & 57 & $<2$ & 15 & $<4$ & 3 & 6 & 1120 & $<2$ & 9 & 20 \\
\hline 98ET-11 & $<1$ & 17 & 2 & 11 & 31 & 11 & 83 & $<2$ & 19 & $<4$ & $<2$ & 8 & 1090 & $<2$ & 12 & 17 \\
\hline 98ET-12 & $<1$ & $<10$ & $<2$ & 27 & 10 & $<2$ & 8 & $<2$ & 23 & $<4$ & 11 & 9 & 1220 & $<2$ & 9 & 18 \\
\hline 98ET-13 & $<1$ & 24 & 2 & 8 & 27 & 20 & 91 & $<2$ & 13 & $<4$ & 2 & 9 & 1620 & $<2$ & 12 & 16 \\
\hline 98ET-14 & $<1$ & 16 & 2 & 21 & 30 & 54 & 97 & $<2$ & $<4$ & $<4$ & 5 & 11 & 1160 & $<2$ & 14 & 20 \\
\hline 98ET-15 & $<1$ & 15 & 2 & 12 & 36 & 149 & 9 & $<2$ & $<4$ & $<4$ & $<2$ & 12 & 1060 & $<2$ & 14 & 11 \\
\hline 98ET-16 & $<1$ & 21 & 2 & 26 & 22 & 2 & 70 & $<2$ & 20 & $<4$ & 6 & 7 & 1040 & $<2$ & 9 & 21 \\
\hline 98ET-17 & $<1$ & 17 & $<2$ & 29 & 17 & $<2$ & 39 & $<2$ & 16 & $<4$ & 8 & 15 & 1220 & $<2$ & 10 & 22 \\
\hline 98ET-18 & $<1$ & 15 & 2 & 30 & 27 & 4 & 120 & $<2$ & 18 & $<4$ & 9 & 7 & 1380 & $<2$ & 14 & 25 \\
\hline 98ET-19 & $<1$ & 16 & 2 & 19 & 25 & 10 & 35 & $<2$ & 12 & $<4$ & 7 & 9 & 1190 & $<2$ & 13 & 20 \\
\hline 98ET-20 & $<1$ & 14 & 2 & 11 & 31 & 96 & 117 & $<2$ & 8 & $<4$ & 2 & 9 & 1150 & $<2$ & 13 & 15 \\
\hline 98ET-21 & $<1$ & 14 & 2 & 14 & 30 & 60 & 123 & $<2$ & 4 & $<4$ & 2 & 31 & 1160 & $<2$ & 13 & 16 \\
\hline 98SK009A & 1 & $<10$ & $<2$ & 6 & $<2$ & $<2$ & 8 & $<2$ & 22 & $<4$ & $<2$ & 8 & 494 & $<2$ & 13 & $<9$ \\
\hline 98SK012A & 1 & 73 & 3 & 61 & 29 & 17 & 27 & 4 & 21 & $<4$ & 18 & 5 & 1830 & $<2$ & 24 & 45 \\
\hline 98SK015A & 1 & $<10$ & $<2$ & 18 & 4 & 15 & 12 & $<2$ & 24 & $<4$ & 6 & 7 & 730 & $<2$ & 14 & $<9$ \\
\hline 98SK039B & $<1$ & 21 & 2 & 17 & 36 & 34 & 210 & $<2$ & 8 & $<4$ & 3 & 8 & 1320 & $<2$ & 17 & 22 \\
\hline 98SK040A & 2 & $<10$ & $<2$ & 50 & $<2$ & $<2$ & $<2$ & $<2$ & 25 & $<4$ & 21 & 4 & 89 & 4 & 19 & 13 \\
\hline 98SK043A & 2 & 45 & 2 & 72 & 22 & 6 & 8 & 3 & 26 & $<4$ & 26 & 9 & 1220 & $<2$ & 17 & 46 \\
\hline 98SK047A & 2 & 37 & 3 & 86 & 18 & 4 & 11 & 3 & 19 & $<4$ & 33 & 12 & 1300 & $<2$ & 20 & 48 \\
\hline 98SK054A & $<1$ & 28 & 3 & 37 & 32 & 19 & 220 & 3 & 22 & $<4$ & 9 & 13 & 1500 & $<2$ & 19 & 29 \\
\hline 98SK058A & 1 & 49 & 3 & 84 & 25 & 8 & 29 & 6 & 30 & $<4$ & 32 & 13 & 1410 & $<2$ & 19 & 67 \\
\hline 98SK060A & $<1$ & $<10$ & $<2$ & 12 & 3 & 5 & 4 & $<2$ & 5 & $<4$ & 8 & 6 & 186 & $<2$ & $<4$ & $<9$ \\
\hline
\end{tabular}




\begin{tabular}{|c|c|c|c|c|c|c|c|c|c|c|c|c|c|c|}
\hline Sample \# & $\begin{array}{r}\text { C_ICP40 } \\
\mathrm{Ni}\end{array}$ & $\begin{array}{r}\text { C_ICP40 } \\
\text { Pb }\end{array}$ & $\begin{array}{r}\text { C_ICP40 } \\
\text { Sc }\end{array}$ & $\begin{array}{r}\text { C_ICP40 } \\
\text { Sn }\end{array}$ & $\begin{array}{r}\text { C_ICP40 } \\
\text { Sr }\end{array}$ & $\begin{array}{r}\text { C_ICP40 } \\
\text { Ta }\end{array}$ & $\begin{array}{c}\text { C_ICP40 } \\
\text { Th }\end{array}$ & $\begin{array}{r}\text { C_ICP40 } \\
\text { U }\end{array}$ & $\begin{array}{r}\text { C_ICP40 } \\
\text { V }\end{array}$ & $\begin{array}{r}\text { C_ICP40 } \\
Y\end{array}$ & $\begin{array}{r}\text { C_ICP40 } \\
\text { Yb }\end{array}$ & $\begin{array}{r}\text { C_ICP40 } \\
\text { Zn }\end{array}$ & $\begin{array}{r}\text { C_CO2 C } \\
\text { CO2 }\end{array}$ & $\begin{array}{l}\text { S_CO2 C } \\
\text { RBNT_C }\end{array}$ \\
\hline & ppm & ppm & ppm & ppm & ppm & ppm & ppm & ppm & ppm & ppm & ppm & ppm & $\%$ & $\%$ \\
\hline ZAR\#2-09 & 94 & $<4$ & 48 & $<5$ & 194 & $<40$ & $<6$ & $<100$ & 272 & 13 & 2 & 70 & 0.19 & 0.05 \\
\hline ZAR\#2-10 & 126 & $<4$ & 41 & $<5$ & 251 & $<40$ & $<6$ & $<100$ & 233 & 13 & 2 & 74 & 0.08 & 0.02 \\
\hline ZAR\#2-11 & 79 & $<4$ & 49 & $<5$ & 230 & $<40$ & $<6$ & $<100$ & 259 & 12 & 2 & 76 & 0.38 & 0.1 \\
\hline ZAR\#2-12 & 91 & $<4$ & 46 & $<5$ & 201 & $<40$ & $<6$ & $<100$ & 243 & 12 & 2 & 66 & 0.35 & 0.1 \\
\hline ZAR\#2-14 & 6 & 6 & $<2$ & $<5$ & 363 & $<40$ & $<6$ & $<100$ & 21 & 7 & $<1$ & 19 & 28.9 & 7.89 \\
\hline ZAR\#2-16 & $<3$ & $<4$ & $<2$ & $<5$ & 80 & $<40$ & 7 & $<100$ & 3 & 16 & 2 & 403 & 0.2 & 0.05 \\
\hline ZAR\#2-17 & 5 & $<4$ & 7 & $<5$ & 79 & $<40$ & 8 & $<100$ & 9 & 16 & 3 & 253 & 0.07 & 0.02 \\
\hline ZAR\#2-20 & $<3$ & 10 & 10 & $<5$ & 142 & $<40$ & 6 & $<100$ & 49 & 20 & 3 & 137 & 1.07 & 0.29 \\
\hline ZAR\#2-21 & 7 & 8 & 30 & $<5$ & 551 & $<40$ & $<6$ & $<100$ & 315 & 29 & 4 & 99 & 1.07 & 0.29 \\
\hline ZAR\#2-22 & 11 & 6 & 20 & $<5$ & 528 & $<40$ & $<6$ & $<100$ & 238 & 22 & 3 & 83 & 3.6 & 0.98 \\
\hline ZAR\#2-23 & 115 & 22 & 46 & $<5$ & 335 & $<40$ & $<6$ & $<100$ & 251 & 13 & 3 & 101 & 1.03 & 0.28 \\
\hline ZAR\#2-25 & 21 & $<4$ & 31 & $<5$ & 399 & $<40$ & $<6$ & $<100$ & 278 & 32 & 4 & 131 & 1.86 & 0.51 \\
\hline 98ET-01 & $<3$ & 27 & $<2$ & 6 & 7 & $<40$ & 28 & $<100$ & $<2$ & 56 & 5 & 135 & 0.04 & 0.01 \\
\hline 98ET-02 & 10 & $<4$ & 4 & $<5$ & 91 & $<40$ & $<6$ & $<100$ & 66 & 6 & 1 & 28 & 0.01 & $<0.003$ \\
\hline 98ET-03 & $<3$ & 8 & $<2$ & $<5$ & 161 & $<40$ & 11 & $<100$ & 6 & 3 & $<1$ & 73 & 0.6 & 0.16 \\
\hline 98ET-04 & $<3$ & 9 & $<2$ & $<5$ & 181 & $<40$ & 7 & $<100$ & 5 & 3 & $<1$ & 71 & 1.18 & 0.32 \\
\hline 98ET-05 & 19 & $<4$ & 33 & $<5$ & 295 & $<40$ & $<6$ & $<100$ & 304 & 15 & 3 & 70 & 2.55 & 0.7 \\
\hline 98ET-06 & 3 & $<4$ & 17 & $<5$ & 720 & $<40$ & $<6$ & $<100$ & 244 & 14 & 3 & 91 & 0.92 & 0.25 \\
\hline 98ET-07 & 12 & $<4$ & 22 & $<5$ & 885 & $<40$ & $<6$ & $<100$ & 173 & 23 & 3 & 111 & 1.15 & 0.31 \\
\hline 98ET-08 & 12 & 6 & 18 & $<5$ & 567 & $<40$ & $<6$ & $<100$ & 182 & 14 & 3 & 82 & 1.25 & 0.34 \\
\hline 98ET-09 & 5 & 4 & 14 & $<5$ & 427 & $<40$ & $<6$ & $<100$ & 134 & 24 & 4 & 95 & 1.17 & 0.32 \\
\hline 98ET-10 & 5 & $<4$ & 26 & $<5$ & 616 & $<40$ & $<6$ & $<100$ & 311 & 16 & 2 & 84 & 0.54 & 0.15 \\
\hline 98ET-11 & 13 & $<4$ & 45 & $<5$ & 476 & $<40$ & $<6$ & $<100$ & 398 & 14 & 3 & 89 & 3.69 & 1.01 \\
\hline 98ET-12 & 5 & $<4$ & 16 & $<5$ & 570 & $<40$ & $<6$ & $<100$ & 188 & 21 & 3 & 106 & 2.99 & 0.82 \\
\hline 98ET-13 & 16 & $<4$ & 42 & $<5$ & 601 & $<40$ & $<6$ & $<100$ & 362 & 16 & 3 & 83 & 2.37 & 0.65 \\
\hline 98ET-14 & 39 & $<4$ & 43 & $<5$ & 568 & $<40$ & $<6$ & $<100$ & 317 & 16 & 4 & 85 & 1.56 & 0.43 \\
\hline 98ET-15 & 90 & $<4$ & 56 & $<5$ & 350 & $<40$ & $<6$ & $<100$ & 258 & 11 & 3 & 58 & 1.19 & 0.32 \\
\hline 98ET-16 & 8 & $<4$ & 28 & $<5$ & 411 & $<40$ & $<6$ & $<100$ & 265 & 20 & 4 & 84 & 2.58 & 0.7 \\
\hline 98ET-17 & 4 & $<4$ & 20 & $<5$ & 570 & $<40$ & $<6$ & $<100$ & 196 & 24 & 4 & 100 & 1.57 & 0.43 \\
\hline 98ET-18 & 8 & $<4$ & 29 & $<5$ & 553 & $<40$ & $<6$ & $<100$ & 322 & 24 & 3 & 108 & 0.15 & 0.04 \\
\hline 98ET-19 & 12 & $<4$ & 34 & $<5$ & 754 & $<40$ & $<6$ & $<100$ & 310 & 16 & 3 & 98 & 0.29 & 0.08 \\
\hline 98ET-20 & 62 & $<4$ & 44 & $<5$ & 471 & $<40$ & $<6$ & $<100$ & 284 & 14 & 3 & 70 & 0.05 & 0.01 \\
\hline 98ET-21 & 43 & $<4$ & 42 & $<5$ & 450 & $<40$ & $<6$ & $<100$ & 289 & 15 & 3 & 82 & 0.09 & 0.02 \\
\hline 98SK009A & 4 & 7 & 2 & $<5$ & 986 & $<40$ & $<6$ & $<100$ & 28 & 2 & $<1$ & 54 & 0.42 & 0.11 \\
\hline 98SK012A & 14 & $<4$ & 33 & $<5$ & 356 & $<40$ & $<6$ & $<100$ & 328 & 36 & 4 & 115 & 0.15 & 0.04 \\
\hline 98SK015A & 38 & 5 & $<2$ & $<5$ & 503 & $<40$ & $<6$ & $<100$ & 37 & 7 & 1 & 67 & 0.01 & $<0.003$ \\
\hline 98SK039B & 47 & $<4$ & 37 & $<5$ & 302 & $<40$ & $<6$ & $<100$ & 255 & 27 & 3 & 86 & 0.02 & 0.01 \\
\hline 98SK040A & $<3$ & 14 & 2 & $<5$ & 30 & $<40$ & 20 & $<100$ & 3 & 20 & 3 & 31 & 0.02 & 0.01 \\
\hline 98SK043A & $<3$ & 5 & 27 & $<5$ & 362 & $<40$ & 6 & $<100$ & 261 & 38 & 4 & 121 & 0.8 & 0.22 \\
\hline 98SK047A & $<3$ & 7 & 23 & $<5$ & 341 & $<40$ & 8 & $<100$ & 222 & 42 & 5 & 126 & 6.52 & 1.78 \\
\hline 98SK054A & 38 & $<4$ & 39 & $<5$ & 198 & $<40$ & $<6$ & $<100$ & 436 & 33 & 4 & 111 & 0.55 & 0.15 \\
\hline 98SK058A & 11 & $<4$ & 28 & $<5$ & 344 & $<40$ & 7 & $<100$ & 219 & 43 & 4 & 118 & 2.81 & 0.77 \\
\hline 98SK060A & 8 & $<4$ & 4 & $<5$ & 25 & $<40$ & $<6$ & $<100$ & 40 & 4 & $<1$ & 17 & 1.22 & 0.33 \\
\hline
\end{tabular}




\begin{tabular}{|c|c|c|c|c|}
\hline Sample \# & Location & Rock type & Description & Age \\
\hline $98 S K 060 \mathrm{~B}$ & Keyhole Lake rock pit & greenstone & intermediate dike & pre-Cretaceous \\
\hline 98SK060C & Keyhole Lake rock pit & chert & gray radiolarian chert, bedded & Mississippian \\
\hline 98SK061B & Hamilton Creek & basalt & dike & Tertiary \\
\hline 98SK062B & Southwest of Towers Lake & greenstone & sill, more than 30 meters thick & pre-Cretaceous \\
\hline 98SK075A & Hamilton Creek & gabbro & massive, fine grained & Tertiary \\
\hline 98SK076A & North of Taylor Creek & pillow basalt & foliated greenstone with flattened clinopyroxene & Triassic \\
\hline 98SK082A & North of Little Duncan Canal & pillow basalt & plagioclase porphyritic pillow basalt & Triassic \\
\hline 98SK084A & North of Little Duncan Canal & pillow basalt & core of pillow & Triassic \\
\hline 98SK091A & Trail from Harvey Lake & pillow basalt & massive, not vesicular & Triassic \\
\hline 98SK095A & Island near Helen S. & pillow basalt & core of pillow & Triassic \\
\hline 98SK097A & North of Kah Sheets Bay & gabbro & dike & Tertiary \\
\hline 98SK127B & Frenchie Creek, Zarembo Island & basalt & dike & Tertiary \\
\hline 98SK133A & East of St. John's Harbor & gabbro & 5 meter dike & Tertiary \\
\hline 98SK138A & Little Duncan Canal & basalt & $35 \mathrm{~cm}$ dike & Triassic \\
\hline 98SK139A & Little Duncan Canal & pillow basalt & core of pillow & Triassic \\
\hline 98SK143A & Little Duncan Canal & pillow basalt & fresh basalt & Triassic \\
\hline 98SK155B & East of St. John's Harbor & basalt & 3 meter mafic dike & Tertiary \\
\hline 98SK162A & East of St. John's Harbor & dacite & 15 meter dike & Tertiary \\
\hline 98SK164A & South of St. John's Harbor & gabbro & dike & Tertiary \\
\hline 98SK165B & South of St. John's Harbor & rhyolite & dike & Tertiary \\
\hline 98SK165C & South of St. John's Harbor & basalt & dike & Tertiary \\
\hline 98SK195A & Southeast Zarembo & granite & alkali feldspar granite & Tertiary \\
\hline 98SK196A & Southeast Zarembo & granite & alkali feldspar granite & Tertiary \\
\hline 98SK196B & Southeast Zarembo & basalt & 8 meter dike & Tertiary \\
\hline 98SK203B & Southeast Zarembo & basalt & 2.5 meter dike & Tertiary \\
\hline 98SK207B & Southeast Zarembo & basalt & dike & Tertiary \\
\hline 98SK214B & Central Zarembo & basalt & 1 meter dike & Tertiary \\
\hline 98SK216A & Marsh Island north end & basalt & pillow basalt & Cretaceous \\
\hline 98SK220A & Mosman Inlet & granite & alkali feldspar granite & Tertiary \\
\hline 98SK232A & East of Kindergarten Bay & greenstone & clinopyroxene porphyritic, massive & Cretaceous \\
\hline 98SK234A & West shore of Steamer Knoll & basalt & core of pillow & Cretaceous \\
\hline 98PH315A & W of mouth of Portage Bay & greenstone & massive greenstone & Triassic? \\
\hline $98 \mathrm{PH} 316 \mathrm{C}$ & Portage Island & greenstone & massive greenstone & Triassic? \\
\hline 98PH343A & NW of Bains Cove & basalt & greenstone dike - intruding dated Devonian rocks & Triassic? \\
\hline 98PH419C & W of Lost Zarembo & qtz diorite & qtz diorite with ep \pm chl alteration & Tertiary \\
\hline $98 \mathrm{PH} 438 \mathrm{C}$ & Meter Bight on Zarembo Island & dacitic intrusive & very fine grained gray-green, no phenocrysts; penetrative low-T fabric & Jura-Cretaceous \\
\hline 98PH369D & NE of mouth of Castle River & hb-diorite & foliated hornblende diorite & Triassic? \\
\hline 92KK-01 & Lovelace Creek S end Rocky Pass & basalt & fragmental mafic volcanic & Tertiary-Quaternary \\
\hline $92 \mathrm{KK}-02$ & Lovelace Creek S end Rocky Pass & basalt & porph-aph basalt & Tertiary-Quaternary \\
\hline $92 \mathrm{KK}-03$ & $\mathrm{~N}$ end Rocky Pass & basalt & massive aph alt'd basalt & Tertiary-Quaternary \\
\hline 92KK-04 & $\mathrm{N}$ end Rocky Pass & rhyolite & felsic volcanic or green tuff & Tertiary-Quaternary \\
\hline 92ZA-01 & Quite Harbor, Etolin Island & granite & alkalai granite & Tertiary \\
\hline 92ZA-02 & South tip, Zarembo Island & felsic tuff & pale green felsic tuff & Tertiary-Quaternary \\
\hline
\end{tabular}




\begin{tabular}{|c|c|c|c|c|c|c|c|c|c|c|c|c|c|c|c|}
\hline Sample \# & Unit & DD Lat & DD Long & $\begin{array}{r}\text { C_ICP40 } \\
\text { AI } \\
\%\end{array}$ & $\begin{array}{r}\text { C_ICP40 } \\
\text { Ca } \\
\%\end{array}$ & $\begin{array}{r}\text { C_ICP40 } \\
\text { Fe } \\
\%\end{array}$ & $\begin{array}{r}\text { C_ICP40 } \\
\text { K } \\
\%\end{array}$ & $\begin{array}{r}\text { C_ICP40 } \\
\text { Mg } \\
\%\end{array}$ & $\begin{array}{r}\text { C_ICP40 } \\
\mathrm{Na} \\
\%\end{array}$ & $\begin{array}{r}\text { C_ICP40 } \\
\text { P } \\
\%\end{array}$ & $\begin{array}{r}\text { C_ICP40 } \\
\text { Ti } \\
\%\end{array}$ & $\begin{array}{r}\text { C_ICP40 } \\
\text { Ag } \\
\text { ppm }\end{array}$ & $\begin{array}{r}\text { C_ICP40 } \\
\text { As } \\
\text { ppm }\end{array}$ & $\begin{array}{r}\text { C_ICP40 } \\
\text { Au } \\
\text { ppm }\end{array}$ & $\begin{array}{r}\text { C_ICP40 } \\
\text { Ba } \\
\text { ppm }\end{array}$ \\
\hline 98SK060B & intrudes PMc & 56.9194 & 133.6333 & 7.305 & 1.04 & 5.83 & 1.67 & 3.885 & 1.454 & 0.075 & 0.978 & $<2$ & $<10$ & $<8$ & 317 \\
\hline 98SK060C & PMc & 56.9194 & 133.6333 & 0.83 & 0.473 & 0.28 & 0.4 & 0.255 & 0.081 & 0.005 & 0.058 & $<2$ & $<10$ & $<8$ & 268 \\
\hline 98SK061B & QTd & 56.9306 & 133.5756 & 8.96 & 6.463 & 7.74 & 0.25 & 4.625 & 1.758 & 0.105 & 1.047 & $<2$ & $<10$ & $<8$ & 146 \\
\hline 98SK062B & intrudes PMc & 56.8292 & 133.5653 & 9.74 & 7.124 & 6.02 & 0.84 & 3.74 & 1.957 & 0.06 & 0.449 & $<2$ & $<10$ & $<8$ & 574 \\
\hline 98SK075A & Tgbk & 56.8617 & 133.6306 & 6.875 & 4.531 & 9.38 & 0.45 & 2.19 & 2.703 & 0.32 & 1.599 & $<2$ & 13 & $<8$ & 163 \\
\hline 98SK076A & Trhv & 56.8222 & 133.4222 & 7.56 & 5.229 & 8.18 & 0.15 & 4.165 & 3.116 & 0.04 & 0.661 & $<2$ & $<10$ & $<8$ & 442 \\
\hline 98SK082A & Trhv & 56.6167 & 133.1019 & 8.295 & 8.206 & 7.05 & 0.08 & 3.625 & 1.43 & 0.05 & 1.029 & $<2$ & $<10$ & $<8$ & 61 \\
\hline 98SK084A & Trhv & 56.6153 & 133.1061 & 8.22 & 7.823 & 6.73 & 0.42 & 3.77 & 1.686 & 0.06 & 1.081 & $<2$ & $<10$ & $<8$ & 789 \\
\hline 98SK091A & Trhv & 56.5631 & 133.0597 & 7.6 & 7.77 & 9.39 & 0.13 & 3.25 & 1.316 & 0.07 & 1.202 & $<2$ & $<10$ & $<8$ & 150 \\
\hline 98SK095A & Trhv & 56.5675 & 133.0700 & 5.415 & 6.767 & 13.8 & 0.19 & 3.795 & 1.192 & 0.015 & 0.972 & $<2$ & $<10$ & 13 & 197 \\
\hline 98SK097A & QTd & 56.5325 & 133.0861 & 8.19 & 4.468 & 6.94 & 2.25 & 1.46 & 2.855 & 0.145 & 0.96 & $<2$ & 13 & $<8$ & 1760 \\
\hline 98SK127B & QTd & 56.4175 & 132.9606 & 8.2 & 7.786 & 7.89 & 0.22 & 3.76 & 1.767 & 0.095 & 1.202 & $<2$ & $<10$ & $<8$ & 144 \\
\hline 98SK133A & Tgbk & 56.4256 & 132.9117 & 7.565 & 5.376 & 9.36 & 1.13 & 2.92 & 2.955 & 0.235 & 2.645 & $<2$ & 19 & $<8$ & 445 \\
\hline 98SK138A & Trhv & 56.5772 & 133.1044 & 6.97 & 7.313 & 7.39 & 0.38 & 5.52 & 2.432 & 0.12 & 0.621 & $<2$ & $<10$ & $<8$ & 188 \\
\hline 98SK139A & Trhv & 56.5800 & 133.1056 & 8.395 & 6.888 & 7.78 & 1.31 & 4.44 & 1.036 & 0.055 & 1.11 & $<2$ & 12 & $<8$ & 562 \\
\hline 98SK143A & Trhv & 56.5733 & 133.1222 & 8.485 & 6.704 & 6.66 & 0.91 & 4.16 & 3.211 & 0.14 & 0.748 & $<2$ & 11 & $<8$ & 1210 \\
\hline 98SK155B & QTd & 56.4006 & 132.8333 & 7.7 & 6.363 & 8.79 & 1.12 & 3.265 & 1.558 & 0.16 & 1.593 & $<2$ & 17 & $<8$ & 219 \\
\hline 98SK162A & QTd & 56.4058 & 132.8894 & 6.34 & 0.257 & 1.71 & 3.82 & 0.01 & 2.94 & $<0.005$ & 0.098 & $<2$ & $<10$ & $<8$ & 67 \\
\hline 98SK164A & QTd & 56.3744 & 132.9161 & 8.195 & 6.179 & 8.82 & 1.65 & 4.09 & 1.81 & 0.2 & 1.604 & $<2$ & 17 & $<8$ & 310 \\
\hline 98SK165B & QTd & 56.3803 & 132.8969 & 6 & 0.079 & 0.8 & 4.89 & 0.04 & 1.886 & $<0.005$ & 0.046 & $<2$ & $<10$ & $<8$ & 202 \\
\hline 98SK165C & QTd & 56.3803 & 132.8969 & 7.55 & 5.607 & 8.91 & 0.91 & 2.96 & 2.057 & 0.18 & 1.685 & $<2$ & 12 & 8 & 331 \\
\hline 98SK195A & Tmaz & 56.3189 & 132.8264 & 7.295 & 0.593 & 1.59 & 4.14 & 0.095 & 3.064 & 0.01 & 0.115 & $<2$ & $<10$ & $<8$ & 783 \\
\hline 98SK196A & Tmaz & 56.3256 & 132.8172 & 7.23 & 0.646 & 2.64 & 4.14 & 0.045 & 3.582 & 0.01 & 0.196 & $<2$ & $<10$ & $<8$ & 619 \\
\hline 98SK196B & QTd & 56.3256 & 132.8172 & 8.14 & 4.867 & 7.48 & 1.92 & 3.015 & 2.356 & 0.145 & 1.208 & $<2$ & 12 & $<8$ & 225 \\
\hline 98SK203B & QTd & 56.3294 & 132.7117 & 9.365 & 7.156 & 8.22 & 0.9 & 4.35 & 1.838 & 0.12 & 1.179 & $<2$ & 17 & $<8$ & 197 \\
\hline 98SK207B & QTd & 56.2575 & 132.7369 & 8.845 & 4.09 & 5.34 & 2.79 & 2.91 & 2.451 & 0.1 & 0.788 & $<2$ & 11 & $<8$ & 774 \\
\hline 98SK214B & QTd & 56.3656 & 132.8636 & 8.12 & 5.14 & 8.46 & 2 & 3.8 & 2.456 & 0.12 & 1.328 & $<2$ & 13 & $<8$ & 549 \\
\hline 98SK216A & KJsv & 56.1167 & 132.7186 & 9.62 & 4.405 & 4.89 & 2.71 & 1.43 & 2.75 & 0.11 & 0.644 & $<2$ & $<10$ & $<8$ & 731 \\
\hline 98SK220A & Tmae & 56.1419 & 132.5700 & 5.84 & 0.273 & 1.48 & 3.56 & 0.01 & 2.722 & 0.005 & 0.063 & $<2$ & $<10$ & $<8$ & 27 \\
\hline 98SK232A & KJsv & 56.1878 & 132.6469 & 9.405 & 5.833 & 7.11 & 0.7 & 2.88 & 3.092 & 0.05 & 0.529 & $<2$ & 40 & $<8$ & 260 \\
\hline 98SK234A & KJsv & 56.1242 & 132.7056 & 9.275 & 4.904 & 5.98 & 1.12 & 2.455 & 2.921 & 0.065 & 0.564 & $<2$ & $<10$ & $<8$ & 365 \\
\hline 98PH315A & Trhv & 57.0128 & 133.3389 & 7.32 & 8.127 & 7.58 & 0.04 & 4.605 & 2.09 & 0.045 & 1.075 & $<2$ & $<10$ & $<8$ & 136 \\
\hline $98 \mathrm{PH} 316 \mathrm{C}$ & Trhv & 57.0192 & 133.3456 & 7.18 & 7.203 & 9.83 & 0.14 & 3.475 & 1.625 & 0.06 & 0.897 & $<2$ & $<10$ & 13 & 85 \\
\hline 98PH343A & intrudes Dls & 56.6500 & 133.2114 & 7.46 & 4.473 & 8.68 & 1.52 & 3.2 & 2.138 & 0.065 & 0.863 & $<2$ & $<10$ & $<8$ & 1120 \\
\hline $98 \mathrm{PH} 419 \mathrm{C}$ & $T k d z$ & 56.3744 & 132.9161 & 6.165 & 0.226 & 2.25 & 3.08 & 0.035 & 3.216 & $<0.005$ & 0.127 & $<2$ & $<10$ & $<8$ & 200 \\
\hline $98 \mathrm{PH} 438 \mathrm{C}$ & intrudes KJss & 56.3539 & 132.6764 & 9.005 & 4.683 & 4.32 & 2.41 & 1.22 & 2.451 & 0.12 & 0.305 & $<2$ & $<10$ & $<8$ & 666 \\
\hline 98PH369D & Pzi & 56.6514 & 133.2500 & 8.705 & 3.302 & 6.18 & 1.72 & 1.81 & 2.969 & 0.135 & 0.38 & $<2$ & 16 & $<8$ & 2040 \\
\hline 92KK-01 & QTb & 56.5333 & 133.6667 & 6.6 & 0.1 & 2.1 & 3 & 0.11 & 3.2 & 0.01 & 0.11 & $<2$ & $<10$ & $<8$ & 470 \\
\hline 92KK-02 & QTb & 56.5333 & 133.6667 & 6.1 & 0.05 & 3.6 & 4.8 & 0.04 & 1.7 & 0.01 & 0.11 & $<2$ & $<10$ & $<8$ & 280 \\
\hline 92KK-03 & QTb & 56.7667 & 133.7167 & 8.4 & 4.4 & 7 & 1.1 & 1.9 & 3.3 & 0.2 & 1.2 & $<2$ & $<10$ & $<8$ & 450 \\
\hline 92KK-04 & QTr & 56.8000 & 133.8333 & 6.8 & 0.37 & 1.1 & 4.1 & 0.06 & 2.7 & 0.007 & 0.07 & $<2$ & $<10$ & $<8$ & 900 \\
\hline 92ZA-01 & Tmaz & 56.2167 & 132.6500 & 6.0 & 0.09 & 1.3 & 3.6 & 0.02 & 2.8 & $<0.01$ & 0.03 & $<4$ & $<20$ & $<20$ & 43 \\
\hline 92ZA-02 & QTr & 56.2500 & 132.8000 & 6.5 & 0.09 & 0.91 & 3.8 & 0.05 & 2.5 & $<0.01$ & 0.04 & $<4$ & $<20$ & $<20$ & 360 \\
\hline
\end{tabular}




\begin{tabular}{|c|c|c|c|c|c|c|c|c|c|c|c|c|c|c|c|c|}
\hline Sample \# & $\begin{array}{r}\text { C_ICP40 } \\
\text { Be } \\
\text { ppm } \\
\end{array}$ & $\begin{array}{r}\text { C_ICP40 } \\
\mathbf{B i} \\
\text { ppm } \\
\end{array}$ & $\begin{array}{r}\text { C_ICP40 } \\
\text { Cd } \\
\text { ppm } \\
\end{array}$ & $\begin{array}{r}\text { C_ICP40 } \\
\text { Ce } \\
\text { ppm } \\
\end{array}$ & $\begin{array}{r}\text { C_ICP40 } \\
\text { Co } \\
\text { ppm } \\
\end{array}$ & $\begin{array}{r}\text { C_ICP40 } \\
\text { Cr } \\
\text { ppm } \\
\end{array}$ & $\begin{array}{r}\text { C_ICP40 } \\
\text { Cu } \\
\text { ppm } \\
\end{array}$ & $\begin{array}{r}\text { C_ICP40 } \\
\text { Eu } \\
\text { ppm } \\
\end{array}$ & $\begin{array}{r}\text { C_ICP40 } \\
\text { Ga } \\
\text { ppm } \\
\end{array}$ & $\begin{array}{r}\text { C_ICP40 } \\
\text { Ho } \\
\text { ppm } \\
\end{array}$ & $\begin{array}{r}\text { C_ICP40 } \\
\text { La } \\
\text { ppm } \\
\end{array}$ & $\begin{array}{r}\text { C_ICP40 } \\
\text { Li } \\
\text { ppm } \\
\end{array}$ & $\begin{array}{r}\text { C_ICP40 } \\
\text { Mn } \\
\text { ppm }\end{array}$ & $\begin{array}{r}\text { C_ICP40 } \\
\text { Mo } \\
\text { ppm } \\
\end{array}$ & $\begin{array}{r}\text { C_ICP40 } \\
\text { Nb } \\
\text { ppm }\end{array}$ & $\begin{array}{r}\text { C_ICP40 } \\
\text { Nd } \\
\text { ppm } \\
\end{array}$ \\
\hline 98SK060B & 1 & 25 & $<2$ & 72 & 21 & 9 & 165 & 2 & 22 & $<4$ & 24 & 43 & 230 & $<2$ & 23 & $\overline{41}$ \\
\hline 98SK060C & $<1$ & $<10$ & $<2$ & 8 & $<2$ & $<2$ & 5 & $<2$ & $<4$ & $<4$ & 3 & $<2$ & 82 & $<2$ & $<4$ & $<9$ \\
\hline 98SK061B & $<1$ & 30 & 2 & 43 & 50 & 100 & 32 & 2 & 26 & $<4$ & 12 & 22 & 1020 & $<2$ & 22 & 29 \\
\hline 98SK062B & $<1$ & 12 & $<2$ & 14 & 31 & 39 & 50 & $<2$ & 26 & $<4$ & 7 & 13 & 1110 & $<2$ & 15 & 19 \\
\hline 98SK075A & 1 & 63 & 2 & 81 & 23 & 6 & 14 & 4 & 23 & $<4$ & 26 & 7 & 1340 & $<2$ & 25 & 52 \\
\hline 98SK076A & $<1$ & 27 & 3 & 22 & 38 & 53 & 91 & 2 & 15 & $<4$ & 4 & 18 & 1240 & $<2$ & 11 & 23 \\
\hline 98SK082A & $<1$ & 23 & 2 & 23 & 34 & 72 & 162 & $<2$ & 6 & $<4$ & 4 & 6 & 1100 & $<2$ & 14 & 18 \\
\hline 98SK084A & $<1$ & 26 & 2 & 25 & 31 & 84 & 182 & $<2$ & 24 & $<4$ & 7 & 8 & 1010 & $<2$ & 15 & 22 \\
\hline 98SK091A & $<1$ & 32 & 2 & 25 & 39 & 45 & 217 & 2 & 18 & $<4$ & 6 & 8 & 1230 & $<2$ & 17 & 24 \\
\hline 98SK095A & $<1$ & $<10$ & 4 & 18 & 56 & 13 & 219 & $<2$ & 14 & $<4$ & 4 & 10 & 1700 & 6 & 10 & 32 \\
\hline 98SK097A & 2 & 26 & 2 & 67 & 13 & 17 & 14 & 3 & 15 & $<4$ & 23 & 11 & 1530 & $<2$ & 27 & 42 \\
\hline 98SK127B & 1 & 29 & 2 & 36 & 34 & 46 & 28 & 2 & 17 & $<4$ & 10 & 43 & 1310 & $<2$ & 19 & 26 \\
\hline 98SK133A & 1 & 67 & 3 & 58 & 30 & 31 & 23 & 4 & 29 & $<4$ & 20 & 27 & 1600 & 2 & 30 & 46 \\
\hline 98SK138A & $<1$ & 28 & $<2$ & 37 & 36 & 104 & 90 & 2 & 13 & $<4$ & 11 & 11 & 1230 & $<2$ & 15 & 28 \\
\hline 98SK139A & $<1$ & 30 & 3 & 22 & 42 & 138 & 206 & 2 & 21 & $<4$ & 4 & 22 & 1270 & $<2$ & 19 & 25 \\
\hline 98SK143A & $<1$ & 22 & 2 & 40 & 29 & 46 & 68 & $<2$ & 17 & $<4$ & 13 & 18 & 1150 & $<2$ & 14 & 30 \\
\hline 98SK155B & 1 & 50 & 3 & 48 & 33 & 27 & 27 & 3 & 33 & $<4$ & 14 & 13 & 1390 & $<2$ & 20 & 38 \\
\hline 98SK162A & 9 & $<10$ & $<2$ & 180 & $<2$ & $<2$ & 7 & $<2$ & 41 & $<4$ & 88 & 8 & 262 & 5 & 82 & 80 \\
\hline 98SK164A & 1 & 57 & 2 & 54 & 36 & 35 & 39 & 3 & 20 & $<4$ & 16 & 105 & 1440 & $<2$ & 28 & 39 \\
\hline 98SK165B & 5 & $<10$ & $<2$ & 58 & $<2$ & $<2$ & 4 & $<2$ & 12 & $<4$ & 25 & 12 & 88 & $<2$ & 21 & 22 \\
\hline 98SK165C & 2 & 61 & 3 & 58 & 28 & 22 & 21 & 3 & 18 & $<4$ & 19 & 26 & 1410 & $<2$ & 21 & 43 \\
\hline 98SK195A & 3 & $<10$ & $<2$ & 79 & $<2$ & $<2$ & $<2$ & $<2$ & 22 & $<4$ & 44 & 4 & 276 & 4 & 17 & 29 \\
\hline 98SK196A & 3 & $<10$ & $<2$ & 142 & $<2$ & $<2$ & $<2$ & $<2$ & 34 & $<4$ & 78 & 11 & 579 & 10 & 28 & 54 \\
\hline 98SK196B & 2 & 26 & 2 & 72 & 28 & 25 & 32 & 2 & 20 & $<4$ & 26 & 40 & 1340 & $<2$ & 28 & 39 \\
\hline 98SK203B & 1 & 34 & 3 & 32 & 38 & 49 & 23 & 2 & 14 & $<4$ & 11 & 22 & 1300 & $<2$ & 17 & 29 \\
\hline 98SK207B & 3 & 21 & $<2$ & 41 & 21 & 39 & 9 & $<2$ & $<4$ & $<4$ & 14 & 60 & 1190 & $<2$ & 18 & 21 \\
\hline 98SK214B & $<1$ & 34 & 2 & 37 & 35 & 43 & 21 & 3 & 18 & $<4$ & 11 & 61 & 1360 & $<2$ & 18 & 32 \\
\hline 98SK216A & 2 & 29 & $<2$ & 49 & 11 & $<2$ & 15 & $<2$ & 22 & $<4$ & 16 & 12 & 847 & $<2$ & 15 & 27 \\
\hline 98SK220A & 4 & $<10$ & 2 & 90 & $<2$ & $<2$ & 87 & $<2$ & 28 & $<4$ & 42 & 4 & 195 & 4 & 39 & 41 \\
\hline 98SK232A & $<1$ & 17 & 3 & 13 & 25 & 11 & 131 & $<2$ & 14 & $<4$ & 5 & 21 & 1230 & $<2$ & 15 & 18 \\
\hline 98SK234A & $<1$ & 17 & $<2$ & 20 & 19 & 9 & 130 & $<2$ & 14 & $<4$ & 6 & 10 & 1380 & $<2$ & 14 & 17 \\
\hline 98PH315A & $<1$ & 18 & 3 & 16 & 38 & 131 & 122 & $<2$ & 21 & $<4$ & $<2$ & 11 & 1190 & $<2$ & 16 & 20 \\
\hline 98PH316C & 2 & 12 & 3 & 30 & 40 & 39 & 290 & 3 & 19 & $<4$ & 9 & 13 & 1310 & $<2$ & 9 & 34 \\
\hline 98PH343A & $<1$ & 39 & 3 & 29 & 36 & 23 & 207 & 3 & 20 & $<4$ & 10 & 18 & 1350 & $<2$ & 12 & 31 \\
\hline 98PH419C & 6 & $<10$ & $<2$ & 186 & $<2$ & $<2$ & 10 & $<2$ & 33 & $<4$ & 100 & 5 & 337 & $<2$ & 58 & 78 \\
\hline 98PH438C & 2 & $<10$ & $<2$ & 34 & 10 & 2 & 16 & $<2$ & 18 & $<4$ & 14 & 33 & 1370 & $<2$ & 10 & 21 \\
\hline 98PH369D & $<1$ & $<10$ & 2 & 32 & 23 & 30 & 92 & $<2$ & 20 & $<4$ & 13 & 34 & 786 & $<2$ & 10 & 25 \\
\hline 92KK-01 & 2 & $<10$ & $<2$ & 130 & $<1$ & $<1$ & 3 & $<2$ & 23 & $<4$ & 70 & 25 & 500 & $<2$ & 50 & 58 \\
\hline 92KK-02 & 2 & $<10$ & $<2$ & 170 & $<1$ & $<1$ & 2 & $<2$ & 27 & $<4$ & 99 & 17 & 830 & $<2$ & 36 & 89 \\
\hline 92KK-03 & 2 & $<10$ & $<2$ & 59 & 23 & 11 & 18 & $<2$ & 23 & $<4$ & 30 & 10 & 1200 & $<2$ & 27 & 32 \\
\hline 92KK-04 & 4 & $<10$ & $<2$ & 78 & $<1$ & $<1$ & 1 & $<2$ & 21 & $<4$ & 48 & 16 & 130 & $<2$ & 23 & 34 \\
\hline 92ZA-01 & 5 & $<20$ & $<4$ & 120 & $<2$ & $<2$ & 25 & $<4$ & 25 & $<8$ & 67 & 5 & 250 & $<4$ & 20 & 54 \\
\hline 92ZA-02 & $<2$ & $<20$ & $<4$ & 61 & $<2$ & $<2$ & $<2$ & $<4$ & 20 & $<8$ & 35 & 23 & 260 & $<4$ & $<8$ & 21 \\
\hline
\end{tabular}




\begin{tabular}{|c|c|c|c|c|c|c|c|c|c|c|c|c|c|c|}
\hline Sample \# & $\begin{array}{r}\text { C_ICP40 } \\
\mathrm{Ni}\end{array}$ & $\begin{array}{r}\text { C_ICP40 } \\
\text { Pb }\end{array}$ & $\begin{array}{r}\text { C_ICP40 } \\
\text { Sc }\end{array}$ & $\begin{array}{r}\text { C_ICP40 } \\
\text { Sn }\end{array}$ & $\begin{array}{r}\text { C_ICP40 } \\
\text { Sr }\end{array}$ & $\begin{array}{r}\text { C_ICP40 } \\
\text { Ta }\end{array}$ & $\begin{array}{c}\text { C_ICP40 } \\
\text { Th }\end{array}$ & $\begin{array}{r}\text { C_ICP40 } \\
\text { U }\end{array}$ & $\begin{array}{r}\text { C_ICP40 } \\
\text { V }\end{array}$ & $\begin{array}{r}\text { C_ICP40 } \\
Y\end{array}$ & $\begin{array}{r}\text { C_ICP40 } \\
\text { Yb }\end{array}$ & $\begin{array}{r}\text { C_ICP40 } \\
\text { Zn }\end{array}$ & $\begin{array}{r}\text { C_CO2 C } \\
\text { CO2 }\end{array}$ & $\begin{array}{l}\text { C_CO2 C } \\
\text { RBNT_C }\end{array}$ \\
\hline & ppm & ppm & ppm & ppm & ppm & ppm & ppm & ppm & ppm & ppm & ppm & ppm & $\%$ & $\%$ \\
\hline 98SK060B & 26 & $<4$ & 29 & $<5$ & 24 & $<40$ & 7 & $<100$ & 284 & 34 & 5 & 98 & 1.08 & 0.29 \\
\hline 98SK060C & $<3$ & $<4$ & 2 & $<5$ & 16 & $<40$ & $<6$ & $<100$ & 18 & $<2$ & $<1$ & 4 & 0.85 & 0.23 \\
\hline 98SK061B & 126 & $<4$ & 29 & $<5$ & 301 & $<40$ & $<6$ & $<100$ & 227 & 26 & 3 & 91 & 0.08 & 0.02 \\
\hline 98SK062B & 39 & $<4$ & 35 & $<5$ & 214 & $<40$ & $<6$ & $<100$ & 226 & 17 & 3 & 64 & 0.35 & 0.1 \\
\hline 98SK075A & $<3$ & 5 & 38 & $<5$ & 95 & $<40$ & $<6$ & $<100$ & 196 & 65 & 7 & 126 & 0.04 & 0.01 \\
\hline 98SK076A & 72 & $<4$ & 42 & $<5$ & 55 & $<40$ & $<6$ & $<100$ & 216 & 20 & 2 & 95 & 0.03 & 0.01 \\
\hline 98SK082A & 84 & $<4$ & 36 & $<5$ & 160 & $<40$ & $<6$ & $<100$ & 313 & 20 & 3 & 71 & 1.48 & 0.4 \\
\hline 98SK084A & 110 & $<4$ & 38 & $<5$ & 166 & $<40$ & $<6$ & $<100$ & 292 & 25 & 4 & 67 & 1.98 & 0.54 \\
\hline 98SK091A & 60 & $<4$ & 41 & $<5$ & 206 & $<40$ & $<6$ & $<100$ & 396 & 29 & 4 & 102 & 0.45 & 0.12 \\
\hline 98SK095A & 65 & $<4$ & 60 & $<5$ & 102 & $<40$ & $<6$ & $<100$ & 729 & 25 & 3 & 135 & 0.71 & 0.19 \\
\hline 98SK097A & 7 & 6 & 21 & $<5$ & 361 & $<40$ & $<6$ & $<100$ & 89 & 35 & 4 & 114 & 0.56 & 0.15 \\
\hline 98SK127B & 39 & $<4$ & 35 & $<5$ & 301 & $<40$ & $<6$ & $<100$ & 270 & 27 & 3 & 86 & 2.32 & 0.63 \\
\hline 98SK133A & 14 & 7 & 39 & $<5$ & 451 & $<40$ & $<6$ & $<100$ & 334 & 39 & 4 & 142 & 0.6 & 0.16 \\
\hline 98SK138A & 79 & $<4$ & 37 & $<5$ & 314 & $<40$ & $<6$ & $<100$ & 296 & 16 & 2 & 77 & 0.15 & 0.04 \\
\hline 98SK139A & 175 & $<4$ & 36 & $<5$ & 367 & $<40$ & $<6$ & $<100$ & 341 & 21 & 3 & 91 & 2.26 & 0.62 \\
\hline 98SK143A & 38 & $<4$ & 36 & $<5$ & 812 & $<40$ & $<6$ & $<100$ & 320 & 16 & 3 & 65 & 1.3 & 0.35 \\
\hline 98SK155B & 29 & 5 & 32 & $<5$ & 408 & $<40$ & $<6$ & $<100$ & 317 & 32 & 4 & 124 & 2.49 & 0.68 \\
\hline 98SK162A & $<3$ & 45 & $<2$ & 8 & 19 & $<40$ & 17 & $<100$ & 2 & 72 & 4 & 242 & 0.25 & 0.07 \\
\hline 98SK164A & 46 & $<4$ & 30 & $<5$ & 375 & $<40$ & $<6$ & $<100$ & 254 & 32 & 4 & 108 & 0.09 & 0.02 \\
\hline 98SK165B & 3 & 15 & $<2$ & 8 & 48 & $<40$ & 25 & $<100$ & 3 & 47 & 5 & 38 & 0.01 & $<0.003$ \\
\hline 98SK165C & 13 & 5 & 31 & $<5$ & 286 & $<40$ & $<6$ & $<100$ & 208 & 34 & 3 & 122 & 3.34 & 0.91 \\
\hline 98SK195A & $<3$ & 16 & 3 & $<5$ & 63 & $<40$ & 22 & $<100$ & 7 & 29 & 3 & 51 & 0.33 & 0.09 \\
\hline 98SK196A & $<3$ & 9 & $<2$ & $<5$ & 50 & $<40$ & 17 & $<100$ & 3 & 29 & 4 & 113 & 0.31 & 0.08 \\
\hline 98SK196B & 30 & 7 & 24 & $<5$ & 334 & $<40$ & $<6$ & $<100$ & 200 & 35 & 4 & 103 & 2.58 & 0.7 \\
\hline 98SK203B & 40 & $<4$ & 27 & $<5$ & 431 & $<40$ & $<6$ & $<100$ & 238 & 23 & 2 & 110 & 0.05 & 0.01 \\
\hline 98SK207B & 30 & 6 & 21 & $<5$ & 786 & $<40$ & $<6$ & $<100$ & 173 & 22 & 3 & 168 & 0.02 & 0.01 \\
\hline 98SK214B & 28 & $<4$ & 34 & $<5$ & 394 & $<40$ & $<6$ & $<100$ & 241 & 29 & 3 & 104 & 0.61 & 0.17 \\
\hline 98SK216A & 7 & $<4$ & 11 & $<5$ & 831 & $<40$ & 6 & $<100$ & 143 & 24 & 4 & 102 & 0.06 & 0.02 \\
\hline 98SK220A & $<3$ & 49 & $<2$ & $<5$ & 8 & $<40$ & 25 & $<100$ & $<2$ & 84 & 7 & 275 & 0.01 & $<0.003$ \\
\hline 98SK232A & 15 & 17 & 36 & $<5$ & 858 & $<40$ & $<6$ & $<100$ & 296 & 20 & 3 & 90 & 0.55 & 0.15 \\
\hline 98SK234A & 12 & $<4$ & 26 & $<5$ & 674 & $<40$ & $<6$ & $<100$ & 235 & 25 & 4 & 115 & 0.22 & 0.06 \\
\hline 98PH315A & 84 & $<4$ & 41 & $<5$ & 118 & $<40$ & $<6$ & $<100$ & 306 & 20 & 3 & 68 & 0.02 & 0.01 \\
\hline 98PH316C & 57 & $<4$ & 39 & $<5$ & 170 & $<40$ & $<6$ & $<100$ & 158 & 37 & 3 & 120 & 0.02 & 0.01 \\
\hline 98PH343A & 45 & $<4$ & 40 & $<5$ & 280 & $<40$ & $<6$ & $<100$ & 294 & 32 & 4 & 104 & 0.13 & 0.04 \\
\hline 98PH419C & $<3$ & 25 & $<2$ & 5 & 25 & $<40$ & 23 & $<100$ & 6 & 71 & 6 & 227 & 0.02 & 0.01 \\
\hline $98 \mathrm{PH} 438 \mathrm{C}$ & 10 & $<4$ & 10 & $<5$ & 609 & $<40$ & $<6$ & $<100$ & 128 & 16 & 3 & 78 & 4.15 & 1.13 \\
\hline 98PH369D & 27 & $<4$ & 26 & $<5$ & 304 & $<40$ & $<6$ & $<100$ & 251 & 9 & 2 & 65 & 9.61 & 2.62 \\
\hline $92 \mathrm{KK}-01$ & $<2$ & 11 & $<2$ & $<5$ & 47 & $<40$ & 5 & $<100$ & 7 & 33 & 2 & 110 & & \\
\hline $92 \mathrm{KK}-02$ & $<2$ & 13 & $<2$ & $<5$ & 9 & $<40$ & $<4$ & $<100$ & $<2$ & 36 & 2 & 150 & & \\
\hline $92 \mathrm{KK}-03$ & 4 & 4 & 23 & $<5$ & 340 & $<40$ & 5 & $<100$ & 210 & 34 & 3 & 110 & & \\
\hline $92 \mathrm{KK}-04$ & $<2$ & 20 & 3 & $<5$ & 64 & $<40$ & 20 & $<100$ & $<2$ & 33 & 4 & 47 & & \\
\hline 92ZA-01 & $<4$ & 20 & $<4$ & $<10$ & 7 & $<80$ & 20 & $<200$ & $<4$ & 48 & 4 & 33 & - & \\
\hline 92ZA-02 & $<4$ & 10 & $<4$ & $<10$ & 56 & $<80$ & 20 & $<200$ & 6 & 20 & 2 & 31 & 0.02 & \\
\hline
\end{tabular}




\begin{tabular}{|c|c|c|c|c|}
\hline Sample \# & Location & Rock type & Description & Age \\
\hline 92ZA-03 & South tip, Zarembo Island & basalt & massive, aph, alt'd basalt & Tertiary-Quaternary \\
\hline 93DC-01 & upstream of Frenchie VMS on Zarembo Is & felsic dike & porph qtz-kspar dike & Tertiary-Quaternary \\
\hline 93DC-03 & St. John's Fluorite & basaltic dike & basaltic dike & Tertiary-Quaternary \\
\hline 93DC-04 & St. John's Fluorite & carbonate & limey rock below dike & Triassic (?) \\
\hline 93DC-05 & St. John's Fluorite & vitrophere & spherulitic vitrophere & Tertiary-Quaternary \\
\hline 93DC-06 & St. John's Fluorite & carbonate & limey rock above dike & Triassic (?) \\
\hline 93DC-21 & Little Castle Is. NW end & pillow basalt & alt'd pillow basalt & Triassic \\
\hline 93DC-22 & Little Castle Is. NE corner & basalt & mafic volcanic flow breccia & Triassic \\
\hline 93DC-23A & Little Castle Is. NE corner & basalt & sheared/alt'd volcanic & Triassic \\
\hline 93DC-25 & Little Castle Is. S of rubble pad & basalt & mafic volcanic from shear & Triassic \\
\hline 93DC-26 & Big Castle Is. S tip & basalt & cc veined alt'd basalt from shear & Triassic \\
\hline 93DC-30 & Big Castle Is. N W shore & basalt & basalt flow breccia & Triassic \\
\hline 93DC-32 & Taylor Creek above falls & greenschist & green thin bedded phyllite & Triassic \\
\hline 93DC-33 & Taylor Creek $50 \mathrm{~m}$ below falls & mafic dike & mafic dike & Tertiary-Quaternary \\
\hline 93DC-34 & Taylor Creek $50 \mathrm{~m}$ below falls & greenschist & greenschist $\mathrm{x}$-cut by dike (93DC-33) & Triassic \\
\hline 93DC-35 & Taylor Creek between falls and inlet & mafic dike & mafic dike & Tertiary-Quaternary \\
\hline 93DC-36 & Taylor Creek between falls and inlet & greenschist & greenschist $\mathrm{x}$-cut by dike (93DC-35) & Triassic \\
\hline 93DC-37 & Taylor Creek below large pool & mafic dike & mafic dike & Tertiary-Quaternary \\
\hline 93DC-38 & Taylor Creek below large pool & greenschist & greenschist $\mathrm{x}$-cut by dike (93DC-37) & Triassic \\
\hline 93DC-39 & Taylor Creek on beach at benchmark & mafic dike & mafic dike orange alt'd & Tertiary-Quaternary \\
\hline 93DC-40 & Taylor Creek on beach at benchmark & greenschist & phyllite at loc 93DC-39 & Triassic \\
\hline 93DC-44 & Peninsula W of Grief Island & basalt & mafic volcanic & Triassic \\
\hline 93ZA-17 & Frenchie VMS over portal & grayschist & hanging wall qtz-ser schist & Triassic(?) \\
\hline 93ZA-18 & Frenchie VMS $9.1 \mathrm{~m}$ above portal & grayschist & hanging wall qtz-ser schist & Triassic(?) \\
\hline 93ZA-19 & Frenchie VMS 1.5 below portal & grayschist & musc phyllite & Triassic(?) \\
\hline 93ZA-20 & Frenchie VMS 150 m downstream & grayschist & musc phyllite & Triassic(?) \\
\hline 93ZA-22 & Frenchie VMS at portal & basaltic dike & basaltic dike & Triassic(?) \\
\hline 93ZA-23 & Frenchie VMS downstream & basalt & mafic volcanics & Triassic(?) \\
\hline 93ZA-24 & Frenchie VMS downstream & rhyolite & felsic volcanics & Tertiary-Quaternary \\
\hline
\end{tabular}

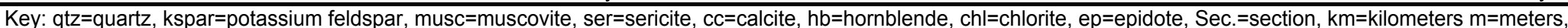

$\mathrm{cm}=$ centimeters, VMS=volcanogenic massive sulfide, alt'd=altered, $x$-cut=cross-cut, porph=porphyritic, aph=aphanitic, CRBNT_C=carbonate carbon. 


\begin{tabular}{|c|c|c|c|c|c|c|c|c|c|c|c|c|c|c|c|}
\hline Sample \# & Unit & DD Lat & DD Long & $\begin{array}{r}\text { C_ICP40 } \\
\text { AI } \\
\% \\
\end{array}$ & $\begin{array}{r}\text { C_ICP40 } \\
\text { Ca } \\
\% \\
\end{array}$ & $\begin{array}{r}\text { C_ICP40 } \\
\text { Fe } \\
\% \\
\end{array}$ & $\begin{array}{r}\text { C_ICP40 } \\
\text { K } \\
\% \\
\end{array}$ & $\begin{array}{r}\text { C_ICP40 } \\
\text { Mg } \\
\% \\
\end{array}$ & $\begin{array}{r}\text { C_ICP40 } \\
\mathrm{Na} \\
\% \\
\end{array}$ & $\begin{array}{r}\text { C_ICP40 } \\
\text { P } \\
\% \\
\end{array}$ & $\begin{array}{r}\text { C_ICP40 } \\
\text { Ti } \\
\% \\
\end{array}$ & $\begin{array}{r}\text { C_ICP40 } \\
\text { Ag } \\
\text { ppm }\end{array}$ & $\begin{array}{r}\text { C_ICP40 } \\
\text { As } \\
\text { ppm }\end{array}$ & $\begin{array}{r}\text { C_ICP40 } \\
\text { Au } \\
\text { ppm }\end{array}$ & $\begin{array}{r}\text { C_ICP40 } \\
\text { Ba } \\
\text { ppm } \\
\end{array}$ \\
\hline 92ZA-03 & QTb & 56.2333 & 132.8000 & 8.5 & 2.2 & 4.5 & 1.2 & 1.1 & 3.1 & 0.08 & 0.53 & $<4$ & $<20$ & $<20$ & 530 \\
\hline 93DC-01 & Qtd & 56.4167 & 132.9333 & 7.3 & 1.3 & 2.4 & 3.8 & 0.49 & 2.5 & 0.04 & 0.21 & $<4$ & $<20$ & $<20$ & 920 \\
\hline 93DC-03 & Qtd & 56.4167 & 132.9500 & 8.1 & 6.5 & 8.7 & 0.71 & 3.5 & 1.5 & 0.15 & 1.4 & $<4$ & $<20$ & $<20$ & 380 \\
\hline 93DC-04 & Trhl & 56.4167 & 132.9500 & 8.0 & 4.9 & 8.3 & 1.7 & 3.0 & 0.66 & 0.17 & 1.3 & $<4$ & 43 & $<20$ & 730 \\
\hline 93DC-05 & Qtd & 56.4167 & 132.9500 & 6.0 & 0.46 & 1.5 & 2.1 & 0.13 & 1.3 & $<0.01$ & 0.08 & $<4$ & 52 & $<20$ & 180 \\
\hline 93DC-06 & Trhl & 56.4167 & 132.9500 & 8.3 & 4.9 & 9.1 & 1.7 & 3.2 & 0.51 & 0.16 & 1.2 & $<4$ & 42 & $<20$ & 380 \\
\hline 93DC-21 & Trhv & 56.6500 & 133.1500 & 7.1 & 5.0 & 9.7 & 1.9 & 3.8 & 2.0 & 0.08 & 1.2 & $<4$ & $<20$ & $<20$ & 2800 \\
\hline 93DC-22 & Trhv & 56.6500 & 133.1500 & 7.3 & 5.5 & 9.1 & 0.66 & 3.7 & 2.9 & 0.07 & 1.2 & $<4$ & $<20$ & $<20$ & 1000 \\
\hline 93DC-23A & Trhv & 56.6500 & 133.1500 & 7.0 & 4.7 & 9.9 & 1.2 & 3.6 & 2.6 & 0.08 & 1.2 & $<4$ & $<20$ & $<20$ & 3500 \\
\hline 93DC-25 & Trhv & 56.6500 & 133.1500 & 7.0 & 6.3 & 9.5 & 0.44 & 3.7 & 2.9 & 0.07 & 1.2 & $<4$ & $<20$ & $<20$ & 950 \\
\hline 93DC-26 & Trhv & 56.6500 & 133.1500 & 1.8 & 16 & 6.4 & 0.13 & 5.5 & 0.05 & 0.02 & 0.28 & $<4$ & $<20$ & $<20$ & 750 \\
\hline 93DC-30 & Trhv & 56.6500 & 133.1667 & 1.8 & 0.03 & 0.53 & 0.86 & 0.14 & 0.02 & $<0.01$ & 0.07 & $<4$ & $<20$ & $<20$ & 1200 \\
\hline 93DC-32 & Trh & 56.7833 & 133.3500 & 6.7 & 6.9 & 7.9 & 0.06 & 3.4 & 2.7 & 0.07 & 0.97 & $<4$ & $<20$ & $<20$ & 210 \\
\hline 93DC-33 & Qtd & 56.7833 & 133.3500 & 8.5 & 6.8 & 8.3 & 0.38 & 3.7 & 2.0 & 0.14 & 1.3 & $<4$ & $<20$ & $<20$ & 180 \\
\hline 93DC-34 & Trh & 56.7833 & 133.3500 & 8.9 & 5.8 & 8.6 & 0.76 & 3.4 & 1.6 & 0.07 & 1.2 & $<4$ & $<20$ & $<20$ & 170 \\
\hline 93DC-35 & Qtd & 56.7833 & 133.3500 & 8.0 & 5.9 & 7.7 & 0.80 & 2.9 & 2.4 & 0.18 & 1.3 & $<4$ & $<20$ & $<20$ & 460 \\
\hline 93DC-36 & Trh & 56.7833 & 133.3500 & 7.2 & 8.5 & 6.9 & 0.16 & 2.7 & 2.1 & 0.05 & 0.73 & $<4$ & $<20$ & $<20$ & 110 \\
\hline 93DC-37 & Qtd & 56.7833 & 133.3333 & 7.6 & 5.7 & 7.2 & 1.0 & 2.2 & 2.4 & 0.20 & 1.3 & $<4$ & $<20$ & $<20$ & 700 \\
\hline 93DC-38 & Trh & 56.7833 & 133.3333 & 8.1 & 2.8 & 10 & 0.76 & 4.9 & 2.5 & 0.08 & 1.3 & $<4$ & $<20$ & $<20$ & 370 \\
\hline 93DC-39 & Qtd & 56.7667 & 133.3167 & 8 & 5.1 & 6.2 & 0.83 & 2.2 & 2.6 & 0.16 & 0.92 & $<4$ & $<20$ & $<20$ & 860 \\
\hline 93DC-40 & Trh & 56.7667 & 133.3167 & 4.6 & 3.9 & 1.5 & 1.7 & 0.63 & 1.4 & 0.04 & 0.16 & $<4$ & $<20$ & $<20$ & 1100 \\
\hline 93DC-44 & Trhv & 56.6167 & 133.1000 & 7.2 & 7.5 & 9.1 & 0.25 & 3.9 & 2.8 & 0.07 & 1.3 & $<4$ & $<20$ & $<20$ & 100 \\
\hline 93ZA-17 & Trhsv & 56.4167 & 132.9500 & 6.6 & 0.03 & 1.7 & 6 & 0.1 & 0.19 & $<0.01$ & 0.04 & 5 & 34 & $<20$ & 810 \\
\hline 93ZA-18 & Trhsv & 56.4167 & 132.9500 & 6.3 & 0.01 & 1.3 & 6.9 & 0.19 & 0.63 & $<0.01$ & 0.05 & $<4$ & 20 & $<20$ & 1500 \\
\hline 93ZA-19 & Trhsv & 56.4167 & 132.9500 & 5.8 & 0.11 & 1.3 & 2 & 1.6 & 0.48 & $<0.01$ & 0.05 & $<4$ & $<20$ & $<20$ & 2800 \\
\hline 93ZA-20 & Trhsv & 56.4167 & 132.9500 & 5.3 & 0.09 & 1.7 & 1.4 & 1.9 & 0.73 & $<0.01$ & 0.05 & $<4$ & $<20$ & $<20$ & 2200 \\
\hline 93ZA-22 & Trhsv & 56.4167 & 132.9500 & 7.9 & 3.4 & 6.6 & 2.5 & 2.5 & 1.3 & 0.18 & 1.1 & $<4$ & 58 & $<20$ & 410 \\
\hline 93ZA-23 & Trhsv & 56.4167 & 132.9500 & 7.4 & 5.7 & 10 & 0.8 & 3.3 & 2.5 & 0.25 & 2.3 & $<4$ & $<20$ & $<20$ & 360 \\
\hline 93ZA-24 & QTr & 56.4167 & 132.9500 & 6.4 & 1.8 & 1.7 & 3.7 & 0.5 & 2.2 & 0.02 & 0.07 & $<4$ & $<20$ & $<20$ & 1200 \\
\hline
\end{tabular}

Key: qtz=qu

$\mathrm{cm}=$ centime 


\begin{tabular}{|c|c|c|c|c|c|c|c|c|c|c|c|c|c|c|c|c|}
\hline Sample \# & $\begin{array}{r}\text { C_ICP40 } \\
\text { Be } \\
\text { ppm }\end{array}$ & $\begin{array}{r}\text { C_ICP40 } \\
\text { Bi } \\
\text { ppm } \\
\end{array}$ & $\begin{array}{r}\text { C_ICP40 } \\
\text { Cd } \\
\text { ppm } \\
\end{array}$ & $\begin{array}{r}\text { C_ICP40 } \\
\text { Ce } \\
\text { ppm } \\
\end{array}$ & $\begin{array}{r}\text { C_ICP40 } \\
\text { Co } \\
\text { ppm } \\
\end{array}$ & $\begin{array}{r}\text { C_ICP40 } \\
\text { Cr } \\
\text { ppm } \\
\end{array}$ & $\begin{array}{r}\text { C_ICP40 } \\
\text { Cu } \\
\text { ppm } \\
\end{array}$ & $\begin{array}{r}\text { C_ICP40 } \\
\text { Eu } \\
\text { ppm } \\
\end{array}$ & $\begin{array}{r}\text { C_ICP40 } \\
\text { Ga } \\
\text { ppm }\end{array}$ & $\begin{array}{r}\text { C_ICP40 } \\
\text { Ho } \\
\text { ppm } \\
\end{array}$ & $\begin{array}{r}\text { C_ICP40 } \\
\text { La } \\
\text { ppm } \\
\end{array}$ & $\begin{array}{r}\text { C_ICP40 } \\
\text { Li } \\
\text { ppm } \\
\end{array}$ & $\begin{array}{r}\text { C_ICP40 } \\
\text { Mn } \\
\text { ppm } \\
\end{array}$ & $\begin{array}{r}\text { C_ICP40 } \\
\text { Mo } \\
\text { ppm } \\
\end{array}$ & $\begin{array}{r}\text { C_ICP40 } \\
\text { Nb } \\
\text { ppm } \\
\end{array}$ & $\begin{array}{r}\text { C_ICP40 } \\
\text { Nd } \\
\text { ppm } \\
\end{array}$ \\
\hline 92ZA-03 & $<2$ & $<20$ & $<4$ & 32 & 24 & 34 & 10 & $<4$ & 20 & $<8$ & 20 & 36 & 1000 & $<4$ & $<8$ & 10 \\
\hline 93DC-01 & $<2$ & $<20$ & $<4$ & 78 & 7 & 8 & 6 & $<4$ & 24 & $<8$ & 47 & 25 & 420 & $<4$ & 18 & 33 \\
\hline 93DC-03 & $<2$ & $<20$ & $<4$ & 37 & 48 & 81 & 12 & $<4$ & 26 & $<8$ & 18 & 32 & 1400 & $<4$ & 20 & 22 \\
\hline 93DC-04 & 3 & $<20$ & $<4$ & 38 & 46 & 79 & 20 & $<4$ & 24 & $<8$ & 17 & 69 & 1400 & $<4$ & 23 & 25 \\
\hline 93DC-05 & 2 & $<20$ & $<4$ & 100 & $<2$ & $<2$ & 4 & $<4$ & 30 & $<8$ & 59 & 12 & 170 & 9 & 47 & 49 \\
\hline 93DC-06 & 2 & $<20$ & $<4$ & 41 & 54 & 87 & 13 & $<4$ & 31 & $<8$ & 19 & 85 & 1400 & $<4$ & 18 & 25 \\
\hline 93DC-21 & $<2$ & $<20$ & $<4$ & 22 & 55 & 170 & 220 & $<4$ & 23 & $<8$ & 7 & 24 & 1800 & $<4$ & 21 & 13 \\
\hline 93DC-22 & $<2$ & $<20$ & $<4$ & 22 & 59 & 200 & 240 & $<4$ & 21 & $<8$ & 8 & 16 & 1300 & $<4$ & 22 & 17 \\
\hline 93DC-23A & $<2$ & $<20$ & $<4$ & 21 & 54 & 160 & 180 & $<4$ & 21 & $<8$ & 8 & 22 & 1700 & $<4$ & 21 & 12 \\
\hline 93DC-25 & $<2$ & $<20$ & $<4$ & 18 & 55 & 170 & 230 & $<4$ & 21 & $<8$ & 7 & 18 & 1700 & $<4$ & 21 & 15 \\
\hline 93DC-26 & $<2$ & $<20$ & $<4$ & $<8$ & 18 & 52 & 55 & $<4$ & $<8$ & $<8$ & 4 & 16 & 1900 & $<4$ & $<8$ & 9 \\
\hline 93DC-30 & $<2$ & $<20$ & $<4$ & 10 & $<2$ & 29 & 29 & $<4$ & $<8$ & $<8$ & 5 & 8 & 27 & $<4$ & $<8$ & $<8$ \\
\hline 93DC-32 & $<2$ & $<20$ & $<4$ & 19 & 39 & 220 & 200 & $<4$ & 19 & $<8$ & 6 & 15 & 1500 & $<4$ & 17 & 11 \\
\hline 93DC-33 & $<2$ & $<20$ & $<4$ & 33 & 49 & 100 & 32 & $<4$ & 25 & $<8$ & 15 & 21 & 1400 & $<4$ & 24 & 18 \\
\hline 93DC-34 & $<2$ & $<20$ & $<4$ & 23 & 53 & 250 & 150 & $<4$ & 24 & $<8$ & 8 & 12 & 1300 & $<4$ & 22 & 15 \\
\hline 93DC-35 & $<2$ & $<20$ & $<4$ & 46 & 36 & 100 & 11 & $<4$ & 22 & $<8$ & 22 & 18 & 1400 & $<4$ & 20 & 27 \\
\hline 93DC-36 & $<2$ & $<20$ & $<4$ & 15 & 39 & 260 & 510 & $<4$ & 17 & $<8$ & 7 & 13 & 1700 & $<4$ & 17 & 9 \\
\hline 93DC-37 & $<2$ & $<20$ & $<4$ & 45 & 29 & 53 & 13 & $<4$ & 22 & $<8$ & 23 & 22 & 1500 & $<4$ & 21 & 25 \\
\hline 93DC-38 & $<2$ & $<20$ & $<4$ & 23 & 60 & 300 & 370 & $<4$ & 25 & $<8$ & 8 & 25 & 1100 & $<4$ & 26 & 14 \\
\hline 93DC-39 & $<2$ & $<20$ & $<4$ & 51 & 30 & 73 & 17 & $<4$ & 19 & $<8$ & 25 & 15 & 1200 & $<4$ & 24 & 28 \\
\hline 93DC-40 & $<2$ & $<20$ & $<4$ & 22 & 7 & 12 & 34 & $<4$ & 11 & $<8$ & 12 & 9 & 1500 & $<4$ & 8 & 14 \\
\hline 93DC-44 & $<2$ & $<20$ & $<4$ & 23 & 51 & 260 & 240 & $<4$ & 18 & $<8$ & 8 & 6 & 1500 & $<4$ & 21 & 15 \\
\hline 93ZA-17 & 2 & $<20$ & $<4$ & 48 & $<2$ & 4 & 320 & $<4$ & 20 & $<8$ & 25 & 4 & 21 & $<4$ & 17 & 24 \\
\hline 93ZA-18 & $<2$ & $<20$ & $<4$ & 23 & $<2$ & $<2$ & 6 & $<4$ & 14 & $<8$ & 12 & 5 & 52 & $<4$ & 16 & 14 \\
\hline 93ZA-19 & 3 & $<20$ & $<4$ & 73 & $<2$ & $<2$ & 9 & $<4$ & 18 & $<8$ & 41 & 22 & 130 & $<4$ & 17 & 40 \\
\hline 93ZA-20 & 2 & $<20$ & $<4$ & 33 & $<2$ & 2 & 10 & $<4$ & 16 & $<8$ & 17 & 32 & 120 & $<4$ & 15 & 17 \\
\hline 93ZA-22 & 2 & $<20$ & $<4$ & 53 & 27 & 60 & 11 & $<4$ & 20 & $<8$ & 26 & 40 & 930 & $<4$ & 27 & 28 \\
\hline 93ZA-23 & $<2$ & $<20$ & $<4$ & 54 & 43 & 98 & 20 & $<4$ & 24 & $<8$ & 21 & 30 & 1900 & $<4$ & 31 & 35 \\
\hline 93ZA-24 & $<2$ & $<20$ & $<4$ & 70 & 3 & $<2$ & 6 & $<4$ & 11 & $<8$ & 43 & 35 & 400 & $<4$ & 12 & 26 \\
\hline
\end{tabular}

Key: qtz=qu

$\mathrm{cm}=$ centime 


\begin{tabular}{|c|c|c|c|c|c|c|c|c|c|c|c|c|c|}
\hline Sample \# & $\begin{array}{r}\text { C_ICP40 } \\
\mathrm{Ni}\end{array}$ & $\begin{array}{r}\text { C_ICP40 } \\
\text { Pb }\end{array}$ & $\begin{array}{r}\text { C_ICP40 } \\
\text { Sc }\end{array}$ & $\begin{array}{r}\text { C_ICP40 } \\
\text { Sn }\end{array}$ & $\begin{array}{r}\text { C_ICP40 } \\
\text { Sr }\end{array}$ & $\begin{array}{r}\text { C_ICP40 } \\
\text { Ta }\end{array}$ & $\begin{array}{r}\text { C_ICP40 } \\
\text { Th }\end{array}$ & $\begin{array}{r}\text { C_ICP40 } \\
\text { U }\end{array}$ & $\begin{array}{r}\text { C_ICP40 } \\
\text { V }\end{array}$ & $\begin{array}{r}\text { C_ICP40 } \\
Y\end{array}$ & $\begin{array}{r}\text { C_ICP40 } \\
\text { Yb }\end{array}$ & $\begin{array}{r}\text { C_ICP40 } \\
\text { Zn }\end{array}$ & $\begin{array}{r}\text { C_CO2 C C_CO2 C } \\
\text { CO2 CRBNT_C }\end{array}$ \\
\hline & ppm & ppm & $\mathrm{ppm}$ & ppm & ppm & ppm & ppm & ppm & ppm & ppm & ppm & ppm & $\%$ \\
\hline 92ZA-03 & 20 & $<8$ & 10 & $<10$ & 360 & $<80$ & $<8$ & $<200$ & 120 & 10 & $<2$ & 66 & 1.46 \\
\hline 93DC-01 & $<4$ & 19 & 6 & $<10$ & 180 & $<80$ & 11 & $<200$ & 38 & 23 & 2 & 63 & 1.25 \\
\hline 93DC-03 & 24 & $<8$ & 32 & $<10$ & 480 & $<80$ & $<8$ & $<200$ & 300 & 24 & 4 & 110 & 1.93 \\
\hline 93DC-04 & 25 & $<8$ & 30 & $<10$ & 370 & $<80$ & $<8$ & $<200$ & 290 & 25 & 4 & 100 & 4.79 \\
\hline 93DC-05 & $<4$ & 29 & $<4$ & $<10$ & 45 & $<80$ & $<8$ & $<200$ & $<4$ & 28 & 3 & 130 & 0.48 \\
\hline 93DC-06 & 27 & $<8$ & 32 & $<10$ & 340 & $<80$ & $<8$ & $<200$ & 340 & 26 & 4 & 110 & - \\
\hline 93DC-21 & 65 & $<8$ & 44 & $<10$ & 140 & $<80$ & $<8$ & $<200$ & 410 & 25 & $<2$ & 120 & 0.36 \\
\hline 93DC-22 & 74 & $<8$ & 45 & $<10$ & 300 & $<80$ & $<8$ & $<200$ & 410 & 23 & $<2$ & 100 & 0.09 \\
\hline 93DC-23A & 67 & $<8$ & 44 & $<10$ & 220 & $<80$ & $<8$ & $<200$ & 420 & 25 & $<2$ & 100 & 2.28 \\
\hline 93DC-25 & 71 & $<8$ & 43 & $<10$ & 400 & $<80$ & $<8$ & $<200$ & 410 & 24 & 2 & 110 & 0.86 \\
\hline 93DC-26 & 25 & $<8$ & 17 & $<10$ & 420 & $<80$ & $<8$ & $<200$ & 170 & 15 & $<2$ & 39 & 32.1 \\
\hline 93DC-30 & 9 & 12 & 5 & $<10$ & 8 & $<80$ & $<8$ & $<200$ & 75 & $<4$ & $<2$ & 13 & $<0.01$ \\
\hline 93DC-32 & 70 & $<8$ & 35 & $<10$ & 130 & $<80$ & $<8$ & $<200$ & 330 & 18 & $<2$ & 78 & 6.70 \\
\hline 93DC-33 & 45 & $<8$ & 32 & $<10$ & 270 & $<80$ & $<8$ & $<200$ & 250 & 26 & 4 & 100 & 0.69 \\
\hline 93DC-34 & 90 & $<8$ & 40 & $<10$ & 330 & $<80$ & $<8$ & $<200$ & 390 & 22 & 2 & 100 & 2.00 \\
\hline 93DC-35 & 15 & $<8$ & 33 & $<10$ & 330 & $<80$ & $<8$ & $<200$ & 270 & 30 & 5 & 110 & 0.83 \\
\hline 93DC-36 & 75 & $<8$ & 38 & $<10$ & 200 & $<80$ & $<8$ & $<200$ & 300 & 14 & $<2$ & 82 & 5.40 \\
\hline 93DC-37 & $<4$ & $<8$ & 30 & $<10$ & 350 & $<80$ & $<8$ & $<200$ & 270 & 31 & 4 & 110 & 1.94 \\
\hline 93DC-38 & 95 & $<8$ & 47 & $<10$ & 33 & $<80$ & $<8$ & $<200$ & 440 & 27 & $<2$ & 100 & 1.59 \\
\hline 93DC-39 & 20 & $<8$ & 25 & $<10$ & 440 & $<80$ & $<8$ & $<200$ & 170 & 30 & 3 & 88 & \\
\hline 93DC-40 & 5 & $<8$ & 11 & $<10$ & 290 & $<80$ & $<8$ & $<200$ & 66 & 6 & $<2$ & 24 & \\
\hline 93DC-44 & 86 & $<8$ & 46 & $<10$ & 240 & $<80$ & $<8$ & $<200$ & 410 & 25 & 2 & 100 & \\
\hline 93ZA-17 & $<4$ & 1900 & $<4$ & $<10$ & 110 & $<80$ & $<8$ & $<200$ & 17 & 5 & $<2$ & 1200 & \\
\hline 93ZA-18 & $<4$ & 8 & $<4$ & $<10$ & 49 & $<80$ & $<8$ & $<200$ & $<4$ & 15 & $<2$ & 39 & \\
\hline 93ZA-19 & $<4$ & 9 & $<4$ & $<10$ & 65 & $<80$ & $<8$ & $<200$ & $<4$ & 20 & 2 & 200 & \\
\hline 93ZA-20 & $<4$ & 9 & $<4$ & $<10$ & 56 & $<80$ & $<8$ & $<200$ & 5 & 11 & $<2$ & 110 & \\
\hline 93ZA-22 & 6 & $<8$ & 24 & $<10$ & 360 & $<80$ & $<8$ & $<200$ & 200 & 25 & $<2$ & 120 & \\
\hline 93ZA-23 & 17 & $<8$ & 41 & $<10$ & 420 & $<80$ & $<8$ & $<200$ & 330 & 34 & 3 & 150 & \\
\hline 93ZA-24 & $<4$ & 24 & $<4$ & $<10$ & 180 & $<80$ & 15 & $<200$ & 12 & 15 & $<2$ & 40 & \\
\hline
\end{tabular}

Key: qtz=qu

$\mathrm{cm}=$ centime 
Table 2. Results of ICP-10, ICP-40, Au, Hg, total-C, total-S, and CQgeochemical analyses of non-mineralized sedimentary rocks from the Stikine Geophysical Survey Project area.

\begin{tabular}{|c|c|c|c|c|c|c|}
\hline Sample \# & Location & Rock type & Description & Age & Unit & DD Lat \\
\hline 98DC-08 & Woewodski Island north shore & argillite & black, with interbedded tuff & Triassic (?) & Trha & 56.5667 \\
\hline 98DC-23 & Junior Creek & argillite & thin-bedded, platey, dark black, graphitic & Triassic (?) & Trha & 56.6500 \\
\hline 98DC-24 & Junior Creek & argillite & thin-bedded, planar, black, graphitic, pyritic & Triassic (?) & Trha & 56.6500 \\
\hline 98DC-28 & Junior Creek & argillite & black, pyritic, graphitic & Triassic (?) & Trha & 56.6500 \\
\hline 98DC-50 & Wetboot (Towers Creek) & argillite & planar-bedded, graphitic; $27.5 \mathrm{~m}$ upstream of occurrence & Triassic(?) & Trha & 56.8500 \\
\hline 98DC-52 & Wetboot (Towers Creek) & argillite & phyllonitic, black; $0.4 \mathrm{~km}$ downstream of occurrence & Triassic(?) & Trha & 56.8500 \\
\hline 98DC-110 & Little Duncan Bay west side Sec. 13 & argillite & blocky, planar-bedded with turbidite interbeds & Triassic(?) & Trha & 56.5833 \\
\hline ZAR\#1-04 & Frenchie, $\left(50^{\prime}\right)$ & graphitic argillite & $4 \mathrm{~cm}$ thick band of tan carbonate in graphitic argillite & Triassic(?) & Trha & 56.4167 \\
\hline ZAR\#1-05 & Frenchie, $\left(75^{\prime}\right)$ & argillite/tuff & argillite interbedded with pyrite-rich tuff and qtz veins & Triassic(?) & Trha & 56.4167 \\
\hline ZAR\#1-14 & Frenchie, (257') & pyrite-qtz argillite & foliation parallel qtz, thin green tuff and large pyrite cubes & Triassic(?) & Trha & 56.4167 \\
\hline ZAR\#2-01 & Frenchie, (24') & argillite/tuff & argillite interbedded with a waxy textured tuff & Triassic(?) & Trha & 56.4167 \\
\hline ZAR\#2-03 & Frenchie, (53') & chert/siliceous argillite & thin banded, planar-bedded siliceous argillite and chert & Triassic(?) & Trha & 56.4167 \\
\hline ZAR\#2-06 & Frenchie, (161.5') & argillite/tuff & black, thin-bedded, graphitic argillite with thin tuff bands; pyritic & Triassic(?) & Trha & 56.4167 \\
\hline ZAR\#2-07 & Frenchie, (173') & pyritic argillite & thin pyrite laminations in black argillite & Triassic(?) & Trha & 56.4167 \\
\hline ZAR\#2-24 & Frenchie, (471') & siliceous argillite & $2.5 \mathrm{~m}$ thick interval of siliceous argillite/graywacke & Triassic(?) & Trha & 56.4167 \\
\hline ZAR\#2-26 & Frenchie, (500') & ser phyllite & gray banded sericite phyllite & Triassic(?) & Trha & 56.4167 \\
\hline 92KK-05 & Hamilton Creek, Kupreanof Is. & siltstone & banded, gray & Mississippian-Permian (?) & PMc & 56.8667 \\
\hline 92KK-06 & Hamilton Creek, Kupreanof Is. & siltstone & brecciated, with carbonate matrix & Mississippian-Permian (?) & PMc & 56.8667 \\
\hline 93DC-02 & St. John's Fluorite & argillite & argillite & Triassic(?) & Trha & 56.4167 \\
\hline 93DC-14 & Maid of Mexico over portal & graphitic argillite & graphitic argillite & Triassic(?) & Trha & 56.5500 \\
\hline 93DC-15 & east side of Harvey Lake & argillite/phyllite & interbedded argillite and phyllite & Triassic(?) & Trha & 56.5500 \\
\hline 93DC-27 & Big Castle Is. SW shore & limestone & light gray, massive & Triassic & Trhl & 56.6500 \\
\hline 93DC-28 & Big Castle Is. bay on W shore & limestone & limestone & Triassic & Trhl & 56.6500 \\
\hline 93DC-29 & Big Castle Is. bay on W shore & argillite & thin bedded & Triassic & Trha & 56.6500 \\
\hline 93DC-31 & Taylor Creek above falls & limestone & tan to white & Triassic & Trhl & 56.7833 \\
\hline 93DC-41 & Rookery Island & phyllites & carbonaceous thin bedded & Triassic(?) & Trha & 56.6833 \\
\hline 93DC-43 & Rookery Island & phyllites & carbonaceous thin bedded & Triassic(?) & Trha & 56.6833 \\
\hline 93ZA-21 & Frenchie,100 m upstream & argillite & argillite & Triassic(?) & Trha & 56.4167 \\
\hline
\end{tabular}

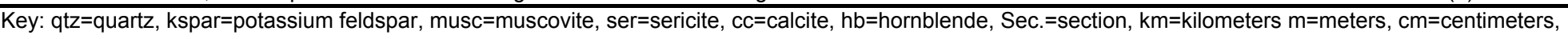

$\mathrm{VMS}=$ volcanogenic massive sulfide, alt'd=altered, $\mathrm{x}$-cut=cross-cut, porph=porphyritic, aph=aphanitic. 
Table 2. Re

\begin{tabular}{|c|c|c|c|c|c|c|c|c|c|c|c|c|c|c|c|}
\hline \multirow[t]{3}{*}{ Sample \# } & \multirow[t]{3}{*}{ DD Long } & \multicolumn{2}{|c|}{ C_Au FA_Hg CVAA } & \multirow{3}{*}{$\begin{array}{r}\text { C_ICP10 } \\
\text { Ag } \\
\text { ppm }\end{array}$} & \multirow{3}{*}{$\begin{array}{r}\text { C_ICP10 } \\
\text { As } \\
\text { ppm }\end{array}$} & \multirow{3}{*}{$\begin{array}{r}\text { C_ICP10 } \\
\text { Au } \\
\text { ppm }\end{array}$} & \multirow{3}{*}{$\begin{array}{r}\text { C_ICP10 } \\
\text { Bi } \\
\text { ppm }\end{array}$} & \multirow{3}{*}{$\begin{array}{r}\text { C_ICP10 } \\
\text { Cd } \\
\text { ppm }\end{array}$} & \multirow{3}{*}{$\begin{array}{r}\text { C_ICP10 } \\
\text { Cu } \\
\text { ppm }\end{array}$} & \multirow{3}{*}{$\begin{array}{r}\text { C_ICP10 } \\
\text { Mo } \\
\text { ppm }\end{array}$} & \multirow{3}{*}{$\begin{array}{r}\text { C_ICP10 } \\
\text { Pb } \\
\text { ppm }\end{array}$} & \multirow{3}{*}{$\begin{array}{r}\text { C_ICP10 } \\
\text { Sb } \\
\text { ppm }\end{array}$} & \multirow{3}{*}{$\begin{array}{r}\text { C_ICP10 } \\
\text { Zn } \\
\text { ppm }\end{array}$} & \multirow{3}{*}{$\begin{array}{r}\text { C_ICP40 } \\
\text { AI } \\
\%\end{array}$} & \multirow{3}{*}{$\begin{array}{r}\text { C_ICP40 } \\
\text { Ca } \\
\%\end{array}$} \\
\hline & & $\mathrm{Au}$ & $\mathrm{Hg}$ & & & & & & & & & & & & \\
\hline & & ppm & $\mathrm{ppm}$ & & & & & & & & & & & & \\
\hline 98DC-08 & 133.0667 & 0.033 & 0.18 & 0.2 & $<1$ & 0.1 & $<1$ & 2.38 & 61.3 & 5.4 & 6 & $<1$ & 89.3 & 4.046 & 5.009 \\
\hline 98DC-23 & 133.0833 & 0.015 & 0.12 & 0.3 & 2 & $<0.1$ & $<1$ & $<0.05$ & 2.63 & 20.2 & 7 & 4 & 3.88 & 1.654 & 0.069 \\
\hline 98DC-24 & 133.0833 & 0.013 & 1.32 & 1 & 17 & 0.1 & $<1$ & 0.77 & 15.2 & 10.4 & 17 & 16 & 105 & 3.185 & 0.387 \\
\hline 98DC-28 & 133.0667 & 0.01 & 0.31 & 0.6 & 22 & $<0.1$ & $<1$ & $<0.05$ & 19.5 & 14 & 51 & 5 & 9.83 & 2.18 & 0.071 \\
\hline 98DC-50 & 133.4000 & 0.024 & 0.72 & 0.2 & 49 & 0.1 & $<1$ & 1.55 & 40.3 & 10.3 & 6 & 5 & 198 & 1.175 & 23.5 \\
\hline 98DC-52 & 133.3833 & 0.01 & 0.11 & $<0.08$ & 2 & $<0.1$ & $<1$ & $<0.05$ & 92.8 & 0.5 & 7 & $<1$ & 79.1 & 8.278 & 0.656 \\
\hline 98DC-110 & 133.1500 & 0.005 & 0.23 & 0.1 & 5 & $<0.1$ & $<1$ & $<0.05$ & 36.9 & 0.9 & 9 & 1 & 81.1 & 8.904 & 0.21 \\
\hline ZAR\#1-04 & 132.9500 & 0.008 & $<0.02$ & 0.4 & 24 & $<0.1$ & $<1$ & 1.28 & 31.3 & 3.8 & 5 & $<1$ & 216 & 2.134 & 9.291 \\
\hline ZAR\#1-05 & 132.9500 & $<0.005$ & $<0.02$ & 0.7 & 11 & 0.2 & $<1$ & 2.08 & 54 & 1.5 & 7 & 2 & 90.4 & 4.402 & 4.897 \\
\hline ZAR\#1-14 & 132.9500 & 0.011 & $<0.02$ & 0.9 & 12 & 0.1 & $<1$ & 2.14 & 30 & 3.8 & 18 & 1 & 177 & 2.122 & 16.4 \\
\hline ZAR\#2-01 & 132.9500 & $<0.005$ & $<0.02$ & 0.2 & 5 & 0.1 & $<1$ & 2.42 & 14.4 & 3.4 & 6 & $<1$ & 153 & 2.51 & 9.125 \\
\hline ZAR\#2-03 & 132.9500 & 0.009 & $<0.02$ & $<0.08$ & 3 & 0.1 & $<1$ & 0.06 & 9.59 & 0.5 & 3 & $<1$ & 37.1 & 1.183 & 21.4 \\
\hline ZAR\#2-06 & 132.9500 & 0.015 & 0.03 & 1.2 & 6 & $<0.1$ & $<1$ & 14.8 & 49.3 & 5.6 & 9 & 4 & 367 & 2.711 & 11.6 \\
\hline ZAR\#2-07 & 132.9500 & 0.009 & $<0.02$ & 0.3 & 32 & $<0.1$ & $<1$ & 0.06 & 18.8 & 3.9 & 10 & 2 & 13.6 & 6.529 & 0.108 \\
\hline ZAR\#2-24 & 132.9500 & 0.007 & $<0.02$ & 0.3 & $<1$ & $<0.1$ & $<1$ & 2.35 & 55.4 & 1.4 & 36 & $<1$ & 183 & 3.876 & 1.571 \\
\hline ZAR\#2-26 & 132.9500 & $<0.005$ & $<0.02$ & 0.1 & 12 & 0.1 & $<1$ & 0.51 & 61.8 & 0.5 & 12 & $<1$ & 178 & 8.386 & 0.573 \\
\hline $92 \mathrm{KK}-05$ & 133.6500 & & & - & - & - & - & - & - & - & - & - & - & 2.1 & 20 \\
\hline $92 \mathrm{KK}-06$ & 133.6500 & & & - & - & - & - & - & - & - & - & - & - & 0.99 & 27 \\
\hline 93DC-02 & 132.9500 & & & - & - & - & - & - & - & - & - & - & - & 8.3 & 2.1 \\
\hline 93DC-14 & 133.0167 & & & N 0.067 & N 1.0 & N 0.10 & N 1.0 & 0.29 & 1.9 & 1.5 & 1.1 & N 1.0 & 24 & 1.6 & 14 \\
\hline 93DC-15 & 133.0333 & & & - & - & - & - & - & - & - & - & - & - & 8.3 & 0.49 \\
\hline 93DC-27 & 133.1667 & & & 0.067 & 2.9 & N 0.10 & N 1.0 & 0.21 & 170 & N 0.10 & 1.3 & N 1.0 & 120 & 7.0 & 5.2 \\
\hline 93DC-28 & 133.1667 & & & - & - & - & - & - & - & - & - & - & - & 7.0 & 6.3 \\
\hline 93DC-29 & 133.1667 & & & - & - & - & - & - & - & - & - & - & - & 0.77 & 3.9 \\
\hline 93DC-31 & 133.3500 & & & - & - & - & - & - & - & - & - & - & - & 0.02 & 41 \\
\hline 93DC-41 & 133.2000 & & & - & - & - & - & - & - & - & - & - & - & 5.6 & 17 \\
\hline 93DC-43 & 133.2000 & & & - & - & - & - & - & - & - & - & - & - & 4.5 & 24 \\
\hline 93ZA-21 & 132.9500 & & & - & - & - & - & - & - & - & - & - & - & 2.2 & 8.1 \\
\hline
\end{tabular}

Key: qtz=qu

VMS=volcan 
Table 2. Re

\begin{tabular}{|c|c|c|c|c|c|c|c|c|c|c|c|c|c|c|c|c|}
\hline Sample \# & $\begin{array}{r}\text { C_ICP40 } \\
\text { Fe } \\
\% \\
\end{array}$ & $\begin{array}{r}\text { C_ICP40 } \\
\text { K } \\
\% \\
\end{array}$ & $\begin{array}{r}\text { C_ICP40 } \\
\text { Mg } \\
\% \\
\end{array}$ & $\begin{array}{r}\text { C_ICP40 } \\
\mathrm{Na} \\
\% \\
\end{array}$ & $\begin{array}{r}\text { C_ICP40 } \\
\text { P } \\
\% \\
\end{array}$ & $\begin{array}{r}\text { C_ICP40 } \\
\text { Ti } \\
\% \\
\end{array}$ & $\begin{array}{r}\text { C_ICP40 } \\
\text { Ag } \\
\text { ppm } \\
\end{array}$ & $\begin{array}{r}\text { C_ICP40 } \\
\text { As } \\
\text { ppm } \\
\end{array}$ & $\begin{array}{r}\text { C_ICP40 } \\
\text { Au } \\
\text { ppm } \\
\end{array}$ & $\begin{array}{r}\text { C_ICP40 } \\
\text { Ba } \\
\text { ppm } \\
\end{array}$ & $\begin{array}{r}\text { C_ICP40 } \\
\text { Be } \\
\text { ppm } \\
\end{array}$ & $\begin{array}{r}\text { C_ICP40 } \\
\text { Bi } \\
\text { ppm } \\
\end{array}$ & $\begin{array}{r}\text { C_ICP40 } \\
\text { Cd } \\
\text { ppm } \\
\end{array}$ & $\begin{array}{r}\text { C_ICP40 } \\
\text { Ce } \\
\text { ppm } \\
\end{array}$ & $\begin{array}{r}\text { C_ICP40 } \\
\text { Co } \\
\text { ppm } \\
\end{array}$ & $\begin{array}{r}\text { C_ICP40 } \\
\text { Cr } \\
\text { ppm } \\
\end{array}$ \\
\hline 98DC-08 & 3.68 & 1.04 & 1.748 & 0.276 & 0.145 & 0.367 & $<2$ & $<10$ & $<8$ & 1010 & $<1$ & $<10$ & 3 & 23 & 8 & 79 \\
\hline 98DC-23 & 0.39 & 0.84 & 0.154 & 0.017 & 0.068 & 0.074 & $<2$ & $<10$ & $<8$ & 2520 & $<1$ & $<10$ & $<2$ & 23 & $<2$ & 35 \\
\hline 98DC-24 & 1.97 & 1.04 & 0.255 & 0.019 & 0.305 & 0.126 & $<2$ & 10 & $<8$ & 2250 & 1 & $<10$ & $<2$ & 24 & $<2$ & 7 \\
\hline 98DC-28 & 2.7 & 0.87 & 0.228 & 0.019 & 0.022 & 0.107 & $<2$ & 21 & $<8$ & 680 & 2 & $<10$ & $<2$ & 29 & 7 & 11 \\
\hline 98DC-50 & 5.06 & 0.15 & 0.898 & 0.006 & 0.276 & 0.048 & $<2$ & 89 & $<8$ & 275 & $<1$ & $<10$ & $<2$ & $<5$ & 3 & 13 \\
\hline 98DC-52 & 3.5 & 3.05 & 0.405 & 0.135 & 0.077 & 0.273 & $<2$ & $<10$ & 10 & 859 & 1 & $<10$ & $<2$ & 35 & 13 & 17 \\
\hline 98DC-110 & 4.96 & 2.28 & 1.691 & 1.345 & 0.087 & 0.504 & $<2$ & $<10$ & $<8$ & 769 & 1 & 16 & $<2$ & 18 & 11 & 43 \\
\hline ZAR\#1-04 & 1.53 & 0.55 & 2.798 & 0.031 & 0.22 & 0.094 & $<2$ & 34 & $<8$ & 1800 & 1 & $<10$ & 2 & 15 & 5 & 111 \\
\hline ZAR\#1-05 & 1.73 & 1.34 & 1.397 & 0.956 & 0.056 & 0.258 & $<2$ & 13 & $<8$ & 2570 & 1 & $<10$ & 2 & 29 & 7 & 11 \\
\hline ZAR\#1-14 & 2.98 & 1.1 & 0.526 & 0.12 & 0.15 & 0.108 & $<2$ & 15 & $<8$ & 1770 & $<1$ & $<10$ & 2 & 9 & 3 & 192 \\
\hline ZAR\#2-01 & 1.33 & 1.05 & 1.286 & 0.327 & 0.087 & 0.124 & $<2$ & $<10$ & $<8$ & 1950 & 1 & $<10$ & 3 & 16 & 6 & 56 \\
\hline ZAR\#2-03 & 0.94 & 0.44 & 0.84 & 0.036 & 0.02 & 0.065 & $<2$ & $<10$ & $<8$ & 965 & $<1$ & $<10$ & $<2$ & 13 & 3 & 12 \\
\hline ZAR\#2-06 & 1.75 & 1.36 & 0.664 & 0.299 & 0.318 & 0.161 & $<2$ & 17 & $<8$ & 1110 & $<1$ & $<10$ & 13 & 13 & 4 & 45 \\
\hline ZAR\#2-07 & 4.03 & 7 & 0.27 & 0.109 & 0.009 & 0.138 & $<2$ & 66 & $<8$ & 177 & 2 & $<10$ & $<2$ & 62 & $<2$ & 3 \\
\hline ZAR\#2-24 & 1.59 & 2.55 & 0.571 & 0.029 & 0.105 & 0.114 & $<2$ & $<10$ & $<8$ & 1250 & 1 & $<10$ & 2 & 25 & $<2$ & 6 \\
\hline ZAR\#2-26 & 4.57 & 2.6 & 1.572 & 1.873 & 0.076 & 0.424 & $<2$ & $<10$ & $<8$ & 1050 & 2 & $<10$ & $<2$ & 33 & 16 & 19 \\
\hline $92 \mathrm{KK}-05$ & 0.74 & 1.1 & 9.5 & 0.04 & 0.22 & 0.1 & $<2$ & $<10$ & $<8$ & 97 & $<1$ & $<10$ & 3 & 13 & 3 & 94 \\
\hline 92KK-06 & 0.4 & 0.44 & 8.1 & 0.02 & 3.9 & 0.05 & $<2$ & $<10$ & $<8$ & 250 & $<1$ & $<10$ & 6 & 11 & 3 & 48 \\
\hline 93DC-02 & 4.5 & 2.2 & 1.7 & 2.4 & 0.10 & 0.46 & $<4$ & 25 & $<20$ & 1000 & $<2$ & $<20$ & $<4$ & 42 & 21 & 71 \\
\hline 93DC-14 & 1.5 & 0.62 & 6.4 & 0.04 & 0.10 & 0.02 & $<4$ & $<20$ & $<20$ & 130 & $<2$ & $<20$ & 6 & $<8$ & 5 & 45 \\
\hline 93DC-15 & 6.8 & 1.7 & 2.6 & 1.9 & 0.10 & 0.64 & $<4$ & $<20$ & $<20$ & 600 & $<2$ & $<20$ & $<4$ & 37 & 20 & 120 \\
\hline 93DC-27 & 8.0 & 0.16 & 2.7 & 2.4 & 0.08 & 1.1 & $<4$ & $<20$ & $<20$ & 460 & $<2$ & $<20$ & $<4$ & 19 & 50 & 170 \\
\hline 93DC-28 & 8.8 & 0.23 & 3.7 & 3.2 & 0.07 & 1.1 & $<4$ & $<20$ & $<20$ & 750 & $<2$ & $<20$ & $<4$ & 19 & 53 & 160 \\
\hline 93DC-29 & 0.59 & 0.34 & 0.56 & 0.02 & $<0.01$ & 0.03 & $<4$ & $<20$ & $<20$ & 600 & $<2$ & $<20$ & $<4$ & $<8$ & $<2$ & 10 \\
\hline 93DC-31 & 0.08 & $<0.02$ & 0.50 & 0.01 & $<0.01$ & $<0.01$ & $<4$ & $<20$ & $<20$ & 310 & $<2$ & $<20$ & $<4$ & $<8$ & 4 & $<2$ \\
\hline 93DC-41 & 2.2 & 3.7 & 0.96 & 0.2 & 0.07 & 0.25 & $<4$ & $<20$ & $<20$ & 1900 & $<2$ & $<20$ & $<4$ & 11 & 11 & 62 \\
\hline 93DC-43 & 2.8 & 2.6 & 0.61 & 0.38 & 0.04 & 0.42 & $<4$ & $<20$ & $<20$ & 2700 & $<2$ & $<20$ & $<4$ & 11 & 10 & 100 \\
\hline 93ZA-21 & 1.4 & 1 & 0.89 & 0.17 & 0.19 & 0.14 & $<4$ & $<20$ & $<20$ & 3700 & $<2$ & $<20$ & $<4$ & 13 & 5 & 110 \\
\hline
\end{tabular}

Key: qtz=qu

VMS=volcan 
Table 2. Re

\begin{tabular}{|c|c|c|c|c|c|c|c|c|c|c|c|c|c|c|c|c|}
\hline Sample \# & $\begin{array}{r}\text { C_ICP40 } \\
\mathrm{Cu} \\
\mathrm{ppm}\end{array}$ & $\begin{array}{r}\text { C_ICP40 } \\
\text { Eu } \\
\text { ppm }\end{array}$ & $\begin{array}{r}\text { C_ICP40 } \\
\text { Ga } \\
\text { ppm }\end{array}$ & $\begin{array}{r}\text { C_ICP40 } \\
\text { Ho } \\
\text { ppm }\end{array}$ & $\begin{array}{r}\text { C_ICP40 } \\
\text { La } \\
\text { ppm }\end{array}$ & $\begin{array}{r}\text { C_ICP40 } \\
\text { Li } \\
\text { ppm }\end{array}$ & $\begin{array}{r}\text { C_ICP40 } \\
\text { Mn } \\
\text { ppm }\end{array}$ & $\begin{array}{r}\text { C_ICP40 } \\
\text { Mo } \\
\text { ppm }\end{array}$ & $\begin{array}{r}\text { C_ICP40 } \\
\text { Nb } \\
\text { ppm }\end{array}$ & $\begin{array}{r}\text { C_ICP40 } \\
\text { Nd } \\
\text { ppm }\end{array}$ & $\begin{array}{r}\text { C_ICP40 } \\
\text { Ni } \\
\text { ppm }\end{array}$ & $\begin{array}{r}\text { C_ICP40 } \\
\text { Pb } \\
\text { ppm }\end{array}$ & $\begin{array}{r}\text { C_ICP40 } \\
\text { Sc } \\
\text { ppm }\end{array}$ & $\begin{array}{r}\text { C_ICP40 } \\
\text { Sn } \\
\text { ppm }\end{array}$ & $\begin{array}{r}\text { C_ICP40 } \\
\text { Sr } \\
\text { ppm }\end{array}$ & $\begin{array}{r}\text { C_ICP40 } \\
\text { Ta } \\
\text { ppm }\end{array}$ \\
\hline 98DC-08 & 75 & $<2$ & 15 & $<4$ & $\overline{9}$ & 20 & 571 & 11 & 5 & 15 & 53 & 4 & 11 & $<5$ & 95 & $<40$ \\
\hline $98 D C-23$ & 10 & $<2$ & 7 & $<4$ & 19 & $<2$ & 8 & 27 & $<4$ & 14 & 10 & 8 & 3 & $<5$ & 8 & $<40$ \\
\hline 98DC-24 & 24 & $<2$ & 13 & $<4$ & 16 & 6 & 19 & 14 & $<4$ & 13 & 27 & 11 & 6 & $<5$ & 64 & $<40$ \\
\hline 98DC-28 & 33 & $<2$ & 14 & $<4$ & 13 & 4 & 42 & 43 & $<4$ & 9 & 89 & 50 & 5 & $<5$ & 21 & $<40$ \\
\hline 98DC-50 & 50 & $<2$ & $<4$ & $<4$ & $<2$ & 10 & 4350 & 22 & $<4$ & $<9$ & 71 & 4 & 3 & $<5$ & 250 & $<40$ \\
\hline 98DC-52 & 93 & $<2$ & 22 & $<4$ & 15 & 20 & 550 & $<2$ & 8 & 18 & 20 & $<4$ & 20 & $<5$ & 70 & $<40$ \\
\hline 98DC-110 & 44 & $<2$ & 19 & $<4$ & 5 & 77 & 1790 & $<2$ & 9 & 13 & 30 & $<4$ & 18 & $<5$ & 168 & $<40$ \\
\hline ZAR\#1-04 & 42 & $<2$ & $<4$ & $<4$ & 12 & 29 & 306 & 6 & $<4$ & $<9$ & 62 & $<4$ & 6 & $<5$ & 273 & $<40$ \\
\hline ZAR\#1-05 & 63 & $<2$ & 17 & $<4$ & 22 & 23 & 203 & $<2$ & 8 & 18 & 26 & $<4$ & 8 & $<5$ & 167 & $<40$ \\
\hline ZAR\#1-14 & 39 & $<2$ & 4 & $<4$ & 12 & 25 & 995 & 6 & $<4$ & $<9$ & 52 & 14 & 5 & $<5$ & 316 & $<40$ \\
\hline ZAR\#2-01 & 21 & $<2$ & 15 & $<4$ & 20 & 32 & 295 & 5 & $<4$ & 17 & 34 & $<4$ & 6 & $<5$ & 165 & $<40$ \\
\hline ZAR\#2-03 & 23 & $<2$ & 8 & $<4$ & 14 & 17 & 688 & $<2$ & $<4$ & $<9$ & 16 & $<4$ & 3 & $<5$ & 402 & $<40$ \\
\hline ZAR\#2-06 & 70 & $<2$ & 5 & $<4$ & 10 & 14 & 247 & 17 & $<4$ & $<9$ & 67 & 6 & 7 & $<5$ & 299 & $<40$ \\
\hline ZAR\#2-07 & 26 & $<2$ & 29 & $<4$ & 33 & 10 & 38 & 6 & 13 & 35 & 4 & 11 & 3 & $<5$ & 51 & $<40$ \\
\hline ZAR\#2-24 & 59 & $<2$ & 9 & $<4$ & 11 & 15 & 291 & 2 & 4 & $<9$ & 8 & 32 & 2 & $<5$ & 81 & $<40$ \\
\hline ZAR\#2-26 & 69 & $<2$ & 16 & $<4$ & 18 & 29 & 1820 & $<2$ & 10 & 21 & 36 & $<4$ & 14 & $<5$ & 76 & $<40$ \\
\hline 92KK-05 & 6 & $<2$ & 6 & $<4$ & 16 & 16 & 330 & $<2$ & 7 & 19 & 14 & $<4$ & 5 & $<5$ & 150 & $<40$ \\
\hline $92 \mathrm{KK}-06$ & 4 & $<2$ & $<4$ & $<4$ & 18 & 4 & 570 & $<2$ & 5 & 17 & 17 & $<4$ & 4 & $<5$ & 260 & $<40$ \\
\hline 93DC-02 & 77 & $<4$ & 21 & $<8$ & 22 & 28 & 1100 & $<4$ & 18 & 25 & 43 & $<8$ & 17 & $<10$ & 300 & $<80$ \\
\hline 93DC-14 & 43 & $<4$ & $<8$ & $<8$ & 7 & 5 & 480 & 31 & 15 & $<8$ & 94 & 15 & 6 & $<10$ & 110 & $<80$ \\
\hline 93DC-15 & 29 & $<4$ & 20 & $<8$ & 14 & 57 & 430 & $<4$ & 18 & 17 & 32 & $<8$ & 20 & $<10$ & 140 & $<80$ \\
\hline 93DC-27 & 230 & $<4$ & 22 & $<8$ & 7 & 49 & 1800 & $<4$ & 20 & 13 & 64 & $<8$ & 42 & $<10$ & 230 & $<80$ \\
\hline 93DC-28 & 210 & $<4$ & 23 & $<8$ & 7 & 20 & 1400 & $<4$ & 21 & 12 & 65 & $<8$ & 42 & $<10$ & 350 & $<80$ \\
\hline 93DC-29 & 10 & $<4$ & $<8$ & $<8$ & $<4$ & 6 & 170 & $<4$ & $<8$ & $<8$ & $<4$ & $<8$ & $<4$ & $<10$ & 79 & $<80$ \\
\hline 93DC-31 & $<2$ & $<4$ & $<8$ & $<8$ & 8 & $<4$ & 3200 & $<4$ & $<8$ & $<8$ & $<4$ & $<8$ & $<4$ & $<10$ & 140 & $<80$ \\
\hline 93DC-41 & 4 & $<4$ & 13 & $<8$ & 7 & 19 & 2800 & $<4$ & 8 & 10 & 10 & $<8$ & 15 & $<10$ & 160 & $<80$ \\
\hline 93DC-43 & 22 & $<4$ & 11 & $<8$ & 6 & 14 & 2800 & $<4$ & 8 & $<8$ & 15 & $<8$ & 20 & $<10$ & 250 & $<80$ \\
\hline 93ZA-21 & 63 & $<4$ & $<8$ & $<8$ & 17 & 12 & 160 & $<4$ & $<8$ & 17 & 69 & $<8$ & 8 & $<10$ & 260 & $<80$ \\
\hline
\end{tabular}

VMS=volcan 
Table 2. $\mathrm{Re}$

\begin{tabular}{|c|c|c|c|c|c|c|c|c|c|c|}
\hline Sample \# & $\begin{array}{r}\text { C_ICP40 } \\
\text { Th }\end{array}$ & $\begin{array}{r}\text { C_ICP40 } \\
\text { U }\end{array}$ & $\begin{array}{r}\text { C_ICP40 } \\
\text { V }\end{array}$ & $\begin{array}{r}\text { C_ICP40 } \\
Y\end{array}$ & $\begin{array}{r}\text { C_ICP40 } \\
Y b\end{array}$ & $\begin{array}{r}\text { C_ICP40 } \\
\text { Zn }\end{array}$ & $\begin{array}{r}\text { C_Tot C } \\
\text { C }\end{array}$ & $\begin{array}{r}\text { C_Tot S } \\
\text { S }\end{array}$ & $\begin{array}{r}\mathrm{C}+\mathrm{CO} 2 \mathrm{C} \\
\mathrm{CO} 2\end{array}$ & $\begin{array}{l}\text { C_CO2 C } \\
\text { CRBNT_C }\end{array}$ \\
\hline & ppm & ppm & ppm & ppm & ppm & ppm & $\%$ & $\%$ & $\%$ & $\%$ \\
\hline 98DC-08 & $<6$ & $<100$ & 220 & 18 & 3 & 86 & 2.15 & 0.23 & 6.23 & 1.7 \\
\hline 98DC-23 & $<6$ & $<100$ & 581 & 4 & 1 & 7 & 3.28 & 0.22 & 0.03 & 0.01 \\
\hline 98DC-24 & 7 & $<100$ & 605 & 11 & 2 & 119 & 1.01 & 1.18 & 0.02 & 0.01 \\
\hline 98DC-28 & 7 & $<100$ & 107 & 7 & 2 & 26 & 0.96 & 2.55 & 0.08 & 0.02 \\
\hline 98DC-50 & $<6$ & $<100$ & 202 & 6 & 2 & 207 & 8.01 & 3.01 & 27.1 & 7.4 \\
\hline 98DC-52 & 6 & $<100$ & 168 & 14 & 2 & 77 & 0.67 & 0.05 & 0.93 & 0.25 \\
\hline 98DC-110 & 7 & $<100$ & 230 & 10 & 3 & 80 & 0.72 & 0.17 & 0.02 & 0.01 \\
\hline ZAR\#1-04 & $<6$ & $<100$ & 151 & 16 & 2 & 204 & 4.76 & $<0.05$ & 9.12 & 2.49 \\
\hline ZAR\#1-05 & $<6$ & $<100$ & 102 & 25 & 2 & 99 & 1.35 & 0.09 & 3.68 & 1 \\
\hline ZAR\#1-14 & $<6$ & $<100$ & 205 & 19 & 2 & 167 & 6.27 & 0.9 & 17.4 & 4.75 \\
\hline ZAR\#2-01 & $<6$ & $<100$ & 125 & 16 & 2 & 142 & 3.48 & $<0.05$ & 9.39 & 2.56 \\
\hline ZAR\#2-03 & $<6$ & $<100$ & 29 & 27 & 2 & 52 & 6.25 & $<0.05$ & 24 & 6.55 \\
\hline ZAR\#2-06 & $<6$ & $<100$ & 293 & 17 & 3 & 354 & 5.14 & 1.62 & 11.8 & 3.22 \\
\hline ZAR\#2-07 & 9 & $<100$ & 11 & 11 & 1 & 19 & 0.35 & 3.83 & 0.09 & 0.02 \\
\hline ZAR\#2-24 & $<6$ & $<100$ & 38 & 17 & 2 & 236 & 0.55 & 0.17 & 1.42 & 0.39 \\
\hline ZAR\#2-26 & 9 & $<100$ & 162 & 8 & 2 & 112 & 0.34 & $<0.05$ & 0.35 & 0.1 \\
\hline 92KK-05 & $<4$ & $<100$ & 130 & 22 & 2 & 71 & & & & \\
\hline 92KK-06 & $<4$ & 100 & 100 & 31 & 2 & 170 & & & & \\
\hline 93DC-02 & 9 & $<200$ & 170 & 20 & $<2$ & 120 & & & 0.91 & \\
\hline 93DC-14 & $<8$ & $<200$ & 750 & 12 & $<2$ & 420 & & & 24.7 & \\
\hline 93DC-15 & $<8$ & $<200$ & 210 & 15 & $<2$ & 130 & & & - & \\
\hline 93DC-27 & $<8$ & $<200$ & 400 & 16 & 2 & 110 & & & 10.8 & \\
\hline 93DC-28 & $<8$ & $<200$ & 400 & 22 & 2 & 100 & & & 0.80 & \\
\hline 93DC-29 & $<8$ & $<200$ & 22 & $<4$ & $<2$ & 4 & & & - & \\
\hline 93DC-31 & $<8$ & $<200$ & 4 & 7 & $<2$ & 17 & & & - & \\
\hline 93DC-41 & $<8$ & $<200$ & 120 & 12 & $<2$ & 9 & & & & \\
\hline 93DC-43 & $<8$ & $<200$ & 150 & 14 & $<2$ & 19 & & & & \\
\hline 93ZA-21 & $<8$ & $<200$ & 130 & 18 & 2 & 170 & & & & \\
\hline
\end{tabular}

VMS=volcan 
Table 3. Results of ICP-10, ICP-40, Au, Hg, and $\mathrm{CO}_{2}$ geochemical analyses of mineralized rocks from the Stikine Geophysical Survey Project area.

\begin{tabular}{|c|c|c|c|c|c|}
\hline $\begin{array}{l}\text { Sample \# } \\
\text { Sam }\end{array}$ & Location & Rock type & Description & Age & Unit \\
\hline 98DC-09 & Woewodski Island north shore & altered tuff & orange, sheared, iron-carb flooded tuff & Triassic (?) & Trsv \\
\hline $98 D C-13$ & Northern Copper & semi-massive sulfide & cpy-rich semi-massive sulfide & Cretaceous(?) & \\
\hline 98DC-14 & Northern Copper & semi-massive sulfide & po, cpy, in fine crystalline greenstone & Cretaceous(?) & Kdi \\
\hline 98DC-20 & Little Castle Island south of pad & qtz-carb-sulfide veins & possibly baritic qtz-carb (stringer?) veins with sulfides & Triassic (?) & \\
\hline 98DC-22 & Junior Creek & massive py & massive to semi-massive 1.2 -m-thick py band in argillite & Triassic (?) & Trha \\
\hline 98DC-25 & Junior Creek & mineralized argillite & silica-barite flooded argillite & Triassic (?) & Trha \\
\hline 98DC-26 & Junior Creek & gabbro & py-rich, coarse crystalline; FLOAT & Triassic (?) & Mzg \\
\hline 98DC-29 & Junior Creek & limestone & qtz-sulfide veined white to light gray w cpy-py-sph-tetr; FLOAT & Triassic (?) & Trhl \\
\hline 98DC-30 & Junior Creek & felsic (?) crystal tuff & crystal tuff cut by cc-barite-sulfide veinlets & Triassic (?) & Trha \\
\hline 98DC-32 & Lost Show & semi-massive sulfide & banded, py-sph-gn in silica-flooded mafic volcanic rock & Triassic (?) & Trhv \\
\hline 98DC-34 & Taylor Creek & semi-massive sulfide & high graded py-sph-gn replacement in limestone & Triassic (?) & Trhl \\
\hline 98DC-35 & Taylor Creek & pyritic limestone & sulfide-rich limestone in creek in margins of dike & Triassic (?) & Trhl \\
\hline 98DC-36 & Taylor Creek & semi-massive sulfide & py concretions in limestone to $2.5 \mathrm{~cm}$ dia, close-packed & Triassic (?) & Trhl \\
\hline 98DC-37 & Taylor Creek & semi-massive sulfide & py concretions in limestone; base-metal rich & Triassic (?) & Trhl \\
\hline 98DC-40 & Coonrod's Zinc & qtz-py-sph-cpy-vein & $15-\mathrm{cm}$-thick qtz-sulfide vein with sulfidized selvages & & \\
\hline 98DC-41 & Coonrod's Zinc & pyritic schist & altered, foliated pyritic schist in selvage of qtz-vein & & Dsv \\
\hline 98DC-44 & Towers Peninsula & musc schist & heavily altered cpy-mineralized host rock & Triassic (?) & Dsv \\
\hline 98DC-45 & Towers Peninsula & semi-massive sulfide & cpy in a silica flooded musc-chl schist & Triassic (?) & Dsv \\
\hline 98DC-47 & Wetboot (Towers Creek) & pyritic phyllite & semi-massive, pyritic, thin-bedded, foliated green-grayschist & Triassic(?) & Trha \\
\hline 98DC-49 & Wetboot (Towers Creek) & pyritic limestone & limestone layer full of nodular py & Triassic(?) & Trha \\
\hline 98DC-53B & Hamilton Creek valley, Sec. 2 & py-veined tuff (?) & silica-flooded tuff cut by hairline py veins in shear & & Trh \\
\hline 98DC-56 & Castle River mouth & greenschist/conglomerate & 0.6-0.9-m-thick bed of pyritic, conglomeratic, chl-musc schist & Triassic (?) & Trh \\
\hline 98DC-58 & Castle River mouth & semi-massive sulfide & 1.2-m-thick horizon of pyritic semi-massive sulfide & Triassic (?) & \\
\hline 98DC-60 & creek draining southwest Fankhauser flat & pyritic limestone & pyritic silty limestone & & PM Cannery (?) \\
\hline 98DC-85 & Harvey Lake South & mineralized basalt & foliated mafic volcanic with $15-20 \%$ py & Triassic (?) & Trhv \\
\hline 98DC-86 & Harvey Lake South & mineralized basalt & foliated mafic volcanic py-sph-rich qtz veinlets & Triassic (?) & Trhv \\
\hline 98DC-88 & Harvey Lake South & semi-massive sulfide & high graded py-sph-rich band from $15-\mathrm{cm}$-thick band in creek & Triassic (?) & \\
\hline 98DC-90 & Harvey Lake East & pyritic tuff & sulfide-bearing altered tuff & Triassic (?) & Trha \\
\hline 98DC-92 & Butterworth Island & qtz-py-sph & high graded sample of thin mineralized horizons in schist & Triassic (?) & Trhsv \\
\hline 98DC-94 & Butterworth Island & massive sulfide & 5 -cm-thick band of massive sulfide from east side & Triassic (?) & \\
\hline 98DC-96 & Helen-S & massive sulfide & massive pyritic sulfide in qtz matrix & Triassic (?) & \\
\hline 98DC-97 & Helen-S & qtz-py-sph-gn-vein & mineralized qtz vein behind cabin, mafic volcanic host & Triassic (?) & Trhv \\
\hline 98DC-99 & Brushy Creek, lower pit & qtz-carb-sulfide veins & stockwork veins in highly altered mafic volcanics & Triassic (?) & Trhv \\
\hline $98 \mathrm{DC}-100$ & Brushy Creek, upper pit & qtz-carb-sulfide veins & stockwork veins in highly altered mafic volcanics & Triassic (?) & Trhv \\
\hline 98DC-101 & Brushy Creek & altered felsic tuff (?) & thin-bedded qtz-ser-schist with sulfides & Triassic (?) & Trhv \\
\hline 98DC-103 & Kushneahin Lake & mineralized rhyolite & rhyolite with abundant dark gray fine crystalline sulfides; FLOAT & Tertiary-Quaternary & QTr \\
\hline 98DC-104 & Kushneahin Lake & mineralized rhyolite & composite mineralized sample as above; FLOAT & Tertiary-Quaternary & $\mathrm{QTr}$ \\
\hline 98DC-105 & Kushneahin Lake & mineralized rhyolite & sooty py veins in altered rhyolite & Tertiary-Quaternary & $\mathrm{QTr}$ \\
\hline 98DC-107 & Kushneahin Lake & mineralized rhyolite & composite from sulfide veined acid-sulfate altered rhyolite & Tertiary-Quaternary & $\mathrm{QTr}$ \\
\hline 98ZA-01 & Frenchie & massive sulfide & pyritic massive sulfide from $7.5 \mathrm{~m}$ downstream of adit & Triassic (?) & \\
\hline 98ZA-02 & Frenchie & massive sulfide & sph-rich massive sulfide from $35 \mathrm{~m}$ downstream of adit & Triassic (?) & \\
\hline 98ZA-03 & Frenchie & massive sulfide & barite-sph-rich massive sulfide from $45 \mathrm{~m}$ downstream of adit & Triassic (?) & \\
\hline
\end{tabular}


Table 3. Re

\begin{tabular}{|c|c|c|c|c|c|c|c|c|c|c|c|c|c|c|c|c|}
\hline Sample \# & DD Lat & DD Long & $\begin{array}{r}\text { C_Au FA } \\
\text { Au } \\
\text { ppm } \\
\end{array}$ & $\begin{array}{r}\text { CVAA } \\
\text { Hg } \\
\text { ppm } \\
\end{array}$ & $\begin{array}{r}\text { C_ICP10 } \\
\text { Ag } \\
\text { ppm } \\
\end{array}$ & $\begin{array}{r}\text { C_ICP10 } \\
\text { As } \\
\text { ppm } \\
\end{array}$ & $\begin{array}{r}\text { C_ICP10 } \\
\text { Au } \\
\text { ppm } \\
\end{array}$ & $\begin{array}{r}\text { C_ICP10 } \\
\text { Bi } \\
\text { ppm } \\
\end{array}$ & $\begin{array}{r}\text { C_ICP10 } \\
\text { Cd } \\
\text { ppm } \\
\end{array}$ & $\begin{array}{r}\text { C_ICP10 } \\
\text { Cu } \\
\text { ppm } \\
\end{array}$ & $\begin{array}{r}\text { C_ICP10 } \\
\text { Mo } \\
\text { ppm } \\
\end{array}$ & $\begin{array}{r}\text { C_ICP10 } \\
\text { Pb } \\
\text { ppm } \\
\end{array}$ & $\begin{array}{r}\text { C_ICP10 } \\
\text { Sb } \\
\text { ppm } \\
\end{array}$ & $\begin{array}{r}\text { C_ICP10 } \\
\text { Zn } \\
\text { ppm } \\
\end{array}$ & $\begin{array}{r}\text { C_ICP40 } \\
\text { Al } \\
\% \\
\end{array}$ & $\begin{array}{r}\text { C_ICP40 } \\
\text { Ca } \\
\% \\
\end{array}$ \\
\hline 98DC-09 & 56.5667 & 133.0500 & 0.01 & 0.51 & $<0.08$ & 4 & 0.2 & $<1$ & 0.06 & 107 & 0.7 & 1 & $<1$ & 49.8 & 5.141 & 10.2 \\
\hline 98DC-13 & 56.8833 & 133.3667 & 0.006 & $<0.02$ & 9.2 & $<1$ & 0.2 & $<1$ & 5.22 & $>500$ & 0.3 & $<1$ & $<1$ & 471 & 0.236 & 11.3 \\
\hline 98DC-14 & 56.8833 & 133.3667 & 0.01 & $<0.02$ & 1.7 & $<1$ & 0.5 & $<1$ & 17.9 & $>500$ & 0.6 & 7 & $<1$ & $>500$ & 1.197 & 8.917 \\
\hline 98DC-20 & 56.6500 & 133.1500 & 0.009 & 5.52 & 0.2 & 34 & $<0.1$ & $<1$ & 38.8 & 21.9 & 0.4 & 666 & 5 & $>500$ & 4.108 & 12.3 \\
\hline 98DC-22 & 56.6500 & 133.0833 & 0.006 & 0.14 & 0.6 & 21 & 0.1 & $<1$ & 0.11 & 23.3 & 5.3 & 13 & 5 & 11 & 4.731 & 0.044 \\
\hline 98DC-25 & 56.6500 & 133.0833 & $<0.005$ & $<0.02$ & 0.1 & 2 & 0.2 & 3 & 0.13 & 37.1 & 76.1 & 3 & 1 & 42.3 & 6.189 & 13.8 \\
\hline 98DC-26 & 56.6500 & 133.0833 & $<0.005$ & $<0.02$ & 0.1 & $<1$ & $<0.1$ & $<1$ & 0.07 & 242 & 0.2 & 2 & $<1$ & 22.4 & 8.797 & 8.052 \\
\hline 98DC-29 & 56.6500 & 133.0667 & 0.006 & 0.98 & 1.7 & $<1$ & $<0.1$ & $<1$ & 41.1 & $>500$ & $<0.1$ & 5 & 1 & $>500$ & 0.092 & 36.1 \\
\hline 98DC-30 & 56.6500 & 133.0833 & $<0.005$ & $<0.02$ & $<0.08$ & 2 & $<0.1$ & $<1$ & 0.11 & 37 & 0.4 & 1 & $<1$ & 25.7 & 6.781 & 11.1 \\
\hline 98DC-32 & 56.5667 & 133.0500 & 0.044 & 331 & 64.2 & 12 & $<0.1$ & $<1$ & $>500$ & 69.8 & 0.3 & 447 & 60 & $>500$ & 0.759 & 0.103 \\
\hline 98DC-34 & 56.7833 & 133.3500 & 0.059 & 60 & 147 & 4 & $<0.1$ & $<1$ & 168 & 297 & 0.6 & $>6000$ & 298 & $>500$ & 0.043 & 8.536 \\
\hline 98DC-35 & 56.7833 & 133.3500 & & & & & & & & & & & & & 0.075 & 14.7 \\
\hline 98DC-36 & 56.7833 & 133.3500 & 0.06 & 8.35 & 8 & 98 & 0.2 & $<1$ & 9.05 & 14.7 & 0.7 & 162 & 69 & $>500$ & 0.091 & 9.795 \\
\hline 98DC-37 & 56.7833 & 133.3500 & 0.17 & 12.5 & 17.3 & 39 & 0.2 & $<1$ & 181 & 42.7 & 1.8 & 3340 & 59 & $>500$ & 0.145 & 10.3 \\
\hline 98DC-40 & 56.8333 & 133.3000 & 0.034 & 0.08 & 0.9 & 2 & $<0.1$ & $<1$ & 3.27 & $>500$ & 0.3 & 11 & $<1$ & $>500$ & 0.351 & 0.015 \\
\hline 98DC-41 & 56.8333 & 133.3000 & 0.304 & 0.12 & 0.5 & 34 & $<0.1$ & $<1$ & 0.12 & 4.53 & 1.6 & 32 & 3 & 17.6 & 2.414 & 0.022 \\
\hline 98DC-44 & 56.8333 & 133.3167 & 0.054 & 0.05 & 1.4 & $<1$ & 0.2 & $<1$ & 0.45 & $>500$ & 0.7 & $<1$ & $<1$ & 52.6 & 11.3 & 6.307 \\
\hline 98DC-45 & 56.8333 & 133.3167 & 0.376 & 0.04 & 1.8 & $<1$ & 0.3 & $<1$ & 0.55 & $>500$ & 2.8 & $<1$ & $<1$ & 101 & 8.85 & 0.959 \\
\hline 98DC-47 & 56.8500 & 133.4000 & 0.021 & 0.56 & $<0.08$ & 8 & 0.2 & $<1$ & 0.15 & $>500$ & 0.9 & 1 & $<1$ & 58 & 7.547 & 1.18 \\
\hline 98DC-49 & 56.8500 & 133.4000 & 0.017 & 4.07 & $<0.08$ & 31 & $<0.1$ & $<1$ & 2.54 & 92.4 & 1.9 & 1 & 2 & 17.4 & 1.145 & 16.9 \\
\hline 98DC-53B & 56.8500 & 133.5333 & $<0.005$ & 0.03 & $<0.08$ & 3 & 0.1 & $<1$ & $<0.05$ & 9.67 & 0.6 & 6 & 1 & 3.88 & 1.612 & 0.019 \\
\hline 98DC-56 & 56.6667 & 133.2500 & $<0.005$ & 12.3 & 12.7 & 58 & $<0.1$ & $<1$ & 49 & 24.9 & 6.6 & 325 & 29 & $>500$ & 1.189 & 0.273 \\
\hline 98DC-58 & 56.6667 & 133.2500 & 0.012 & 7.55 & 16.4 & 382 & 0.2 & $<1$ & 13.8 & 7.96 & 3.1 & 432 & 36 & $>500$ & 0.83 & 0.416 \\
\hline 98DC-60 & 56.6667 & 133.2500 & $<0.005$ & 1.4 & $<0.08$ & 3 & 0.1 & $<1$ & 0.26 & 8.22 & 1 & 4 & $<1$ & 49.7 & 1.867 & 12.8 \\
\hline 98DC-85 & 56.5333 & 133.0167 & 0.101 & 1.38 & 5 & 29 & 0.2 & 3 & 60 & 378 & 0.3 & 168 & 4 & $>500$ & 4.533 & 4.95 \\
\hline 98DC-86 & 56.5333 & 133.0167 & 0.047 & 6.51 & 1.1 & 13 & $<0.1$ & $<1$ & 135 & 317 & 0.2 & 31 & 6 & $>500$ & 5.957 & 10.7 \\
\hline 98DC-88 & 56.5333 & 133.0167 & 0.242 & 2.41 & 12.1 & 57 & 0.2 & 2 & 8.26 & 107 & 0.2 & 46 & 6 & $>500$ & 0.073 & 0.046 \\
\hline 98DC-90 & 56.5500 & 133.0000 & 0.009 & 3.16 & $<0.08$ & $<1$ & 0.2 & $<1$ & 0.34 & 15.2 & 0.5 & 2 & 5 & 154 & 8.393 & 2.434 \\
\hline 98DC-92 & 56.5167 & 133.0500 & 0.366 & 69.3 & 367 & 2 & 0.2 & $<1$ & $>500$ & $>500$ & 1.1 & $>6000$ & 312 & $>500$ & 1.513 & 0.765 \\
\hline 98DC-94 & 56.5167 & 133.0500 & 0.12 & 71.2 & $>400$ & 2 & 0.3 & $<1$ & $>500$ & $>500$ & 1.1 & $>6000$ & 545 & $>500$ & 1.203 & 0.068 \\
\hline 98DC-96 & 56.5667 & 133.0667 & 0.092 & 3.52 & 39.9 & 65 & 0.1 & $<1$ & 16.1 & 16 & 0.3 & 2480 & 96 & $>500$ & 0.043 & 0.075 \\
\hline 98DC-97 & 56.5667 & 133.0667 & 0.025 & 45.6 & 3.9 & 5 & $<0.1$ & $<1$ & 108 & 3.9 & 3.7 & 1270 & 5 & $>500$ & 0.03 & 0.01 \\
\hline 98DC-99 & 56.5167 & 133.0000 & 0.061 & 1.68 & 8.6 & 278 & 0.3 & $<1$ & 307 & 271 & 0.5 & 296 & 20 & $>500$ & 4.242 & 12.8 \\
\hline 98DC-100 & 56.5167 & 133.0000 & 1.13 & 2.94 & 14.4 & 20 & 0.3 & $<1$ & 383 & 334 & 0.3 & 1190 & 38 & $>500$ & 3.076 & 7.492 \\
\hline 98DC-101 & 56.5167 & 133.0000 & 0.115 & 4.67 & 104 & 8 & 0.2 & $<1$ & 195 & 208 & 0.8 & $>6000$ & 416 & $>500$ & 2.208 & 19.9 \\
\hline 98DC-103 & 56.5167 & 133.5000 & 0.019 & 0.39 & 0.5 & 119 & $<0.1$ & $<1$ & 0.81 & 2.32 & 3 & 97 & 3 & 160 & 5.697 & 0.13 \\
\hline 98DC-104 & 56.5167 & 133.5000 & $<0.005$ & 1.9 & 0.1 & 102 & $<0.1$ & $<1$ & 0.28 & 0.34 & 3.2 & 53 & 1 & 124 & 4.84 & 0.089 \\
\hline 98DC-105 & 56.5167 & 133.5000 & 0.011 & 0.93 & $<0.08$ & 42 & 0.1 & $<1$ & 0.14 & 12 & 4.9 & 25 & 3 & 15.8 & 4.449 & 0.075 \\
\hline 98DC-107 & 56.5167 & 133.5000 & 0.021 & 0.45 & $<0.08$ & 280 & $<0.1$ & $<1$ & $<0.05$ & 0.42 & 4.7 & 12 & 2 & 32.7 & 5.459 & 0.133 \\
\hline 98ZA-01 & 56.4167 & 132.9500 & 1.96 & 0.64 & 10.4 & 115 & 1.5 & 9 & 24 & $>500$ & 1.4 & 565 & 6 & $>500$ & 0.706 & 2.169 \\
\hline 98ZA-02 & 56.4167 & 132.9500 & 0.155 & 0.89 & 4 & 186 & 0.1 & $<1$ & 183 & $>500$ & 0.4 & 949 & 10 & $>500$ & 0.177 & 0.709 \\
\hline 98ZA-03 & 56.4167 & 132.9500 & 0.654 & 0.75 & 7 & 63 & 0.4 & $<1$ & 101 & $>500$ & 0.9 & 223 & 9 & $>500$ & 0.065 & 1.095 \\
\hline
\end{tabular}


Table 3. Re

\begin{tabular}{|c|c|c|c|c|c|c|c|c|c|c|c|c|c|c|c|c|}
\hline Sample \# & $\begin{array}{r}\text { C_ICP40 } \\
\text { Fe } \\
\% \\
\end{array}$ & $\begin{array}{r}\text { C_ICP40 } \\
\text { K } \\
\% \\
\end{array}$ & $\begin{array}{r}\text { C_ICP40 } \\
\text { Mg } \\
\% \\
\end{array}$ & $\begin{array}{r}\text { C_ICP40 } \\
\mathrm{Na} \\
\% \\
\end{array}$ & $\begin{array}{r}\text { C_ICP40 } \\
\text { P } \\
\% \\
\end{array}$ & $\begin{array}{r}\text { C_ICP40 } \\
\text { Ti } \\
\% \\
\end{array}$ & $\begin{array}{r}\text { C_ICP40 } \\
\text { Ag } \\
\text { ppm } \\
\end{array}$ & $\begin{array}{r}\text { C_ICP40 } \\
\text { As } \\
\text { ppm } \\
\end{array}$ & $\begin{array}{r}\text { C_ICP40 } \\
\text { Au } \\
\text { ppm } \\
\end{array}$ & $\begin{array}{r}\text { C_ICP40 } \\
\text { Ba } \\
\text { ppm } \\
\end{array}$ & $\begin{array}{r}\text { C_ICP40 } \\
\text { Be } \\
\text { ppm } \\
\end{array}$ & $\begin{array}{r}\text { C_ICP40 } \\
\text { Bi } \\
\text { ppm } \\
\end{array}$ & $\begin{array}{r}\text { C_ICP40 } \\
\text { Cd } \\
\text { ppm } \\
\end{array}$ & $\begin{array}{r}\text { C_ICP40 } \\
\text { Ce } \\
\text { ppm } \\
\end{array}$ & $\begin{array}{r}\text { C_ICP40 } \\
\text { Co } \\
\text { ppm } \\
\end{array}$ & $\begin{array}{r}\text { C_ICP40 } \\
\text { Cr } \\
\text { ppm } \\
\end{array}$ \\
\hline 98DC-09 & 6.99 & 0.56 & 4.241 & 0.083 & 0.04 & 0.616 & $<2$ & $<10$ & $<8$ & 878 & $<1$ & 16 & 3 & 9 & 23 & 106 \\
\hline 98DC-13 & 18.8 & $<0.01$ & 1.203 & 0.112 & 0.386 & $<0.005$ & 13 & $<10$ & $<8$ & 22 & 2 & $<10$ & 9 & $<5$ & 7 & 3 \\
\hline $98 D C-14$ & 22.5 & 0.02 & 1.234 & 0.114 & 0.101 & 0.079 & 5 & $<10$ & $<8$ & 40 & 2 & $<10$ & 21 & $<5$ & 130 & 84 \\
\hline 98DC-20 & 5.75 & 2.55 & 4.657 & 0.879 & 0.028 & 0.105 & 2 & 73 & $<8$ & 143 & 2 & $<10$ & 34 & 16 & 48 & 44 \\
\hline 98DC-22 & 22.5 & 2.23 & 0.456 & 0.275 & 0.021 & 0.103 & 3 & 100 & $<8$ & 14 & $<1$ & $<10$ & 3 & 13 & 70 & 124 \\
\hline 98DC-25 & 2.96 & 1.39 & 1.916 & 1.735 & 0.143 & 0.213 & $<2$ & $<10$ & $<8$ & 2090 & $<1$ & $<10$ & $<2$ & 33 & 31 & 80 \\
\hline 98DC-26 & 7.74 & 1.07 & 2.877 & 1.798 & 0.199 & 0.817 & $<2$ & $<10$ & $<8$ & 565 & 1 & 31 & 3 & 39 & 20 & 2 \\
\hline 98DC-29 & 0.34 & 0.04 & 0.252 & 0.011 & 0.038 & $<0.005$ & 2 & $<10$ & $<8$ & 32 & $<1$ & $<10$ & 38 & 125 & 3 & $<2$ \\
\hline 98DC-30 & 2.58 & 2.99 & 1.21 & 0.4 & 0.168 & 0.224 & $<2$ & $<10$ & $<8$ & 363 & $<1$ & $<10$ & $<2$ & 18 & 25 & 112 \\
\hline 98DC-32 & 6.34 & 0.04 & 0.098 & 0.009 & 0.011 & 0.092 & 61 & 118 & $<8$ & 98 & $<1$ & 37 & 1700 & 6 & 26 & 15 \\
\hline 98DC-34 & 10.8 & 0.02 & 4.386 & 0.006 & 0.025 & $<0.005$ & 170 & 283 & $<8$ & 26 & $<1$ & 32 & 157 & $<5$ & 7 & $<2$ \\
\hline 98DC-35 & 14.7 & 0.03 & 7.305 & 0.01 & 0.015 & $<0.005$ & 33 & 377 & $<8$ & 106 & $<1$ & $<10$ & 26 & 6 & 17 & 5 \\
\hline 98DC-36 & 21.3 & 0.02 & 5.06 & 0.012 & $<0.005$ & $<0.005$ & 18 & 497 & $<8$ & 11 & $<1$ & $<10$ & 5 & $<5$ & 4 & 4 \\
\hline 98DC-37 & 19.3 & 0.03 & 5.578 & 0.01 & 0.023 & $<0.005$ & 27 & 593 & $<8$ & 23 & $<1$ & $<10$ & 158 & $<5$ & 3 & 3 \\
\hline 98DC-40 & 0.51 & 0.18 & 0.028 & 0.012 & 0.017 & $<0.005$ & $<2$ & $<10$ & $<8$ & 104 & $<1$ & $<10$ & 3 & $<5$ & $<2$ & $<2$ \\
\hline 98DC-41 & 9.58 & 1.34 & 0.172 & 0.031 & $<0.005$ & 0.049 & $<2$ & 379 & $<8$ & 49 & $<1$ & $<10$ & $<2$ & $<5$ & 11 & 3 \\
\hline 98DC-44 & 7.75 & 0.72 & 0.056 & 3.591 & 0.412 & 0.146 & $<2$ & $<10$ & $<8$ & 367 & 2 & $<10$ & 3 & 83 & 11 & $<2$ \\
\hline 98DC-45 & 7.58 & 0.15 & 0.272 & 4.818 & 0.715 & 0.168 & 4 & $<10$ & $<8$ & 184 & 1 & $<10$ & 2 & 92 & 59 & $<2$ \\
\hline 98DC-47 & 11.9 & 0.72 & 1.927 & 3.779 & 0.058 & 1.186 & $<2$ & 31 & 11 & 75 & $<1$ & 30 & 4 & 19 & 55 & 79 \\
\hline 98DC-49 & 17.7 & 0.53 & 0.429 & 0.018 & $<0.005$ & 0.016 & $<2$ & 103 & $<8$ & 166 & $<1$ & $<10$ & 6 & $<5$ & 106 & 36 \\
\hline 98DC-53B & 1.07 & 0.85 & 0.151 & 0.008 & $<0.005$ & 0.058 & $<2$ & $<10$ & $<8$ & 389 & $<1$ & $<10$ & $<2$ & 13 & 2 & 7 \\
\hline 98DC-56 & 5.4 & 0.33 & 0.069 & 0.019 & 0.062 & 0.053 & 18 & 670 & $<8$ & 56 & $<1$ & $<10$ & 30 & 11 & 8 & 10 \\
\hline 98DC-58 & 19.9 & 0.4 & 0.049 & 0.015 & 0.194 & 0.029 & 31 & 2410 & $<8$ & 20 & $<1$ & $<10$ & $<2$ & 13 & $<2$ & 11 \\
\hline $98 D C-60$ & 4.8 & 1.08 & 6.45 & 0.114 & 0.035 & 0.043 & $<2$ & $<10$ & $<8$ & 204 & $<1$ & $<10$ & $<2$ & 13 & 3 & 3 \\
\hline 98DC-85 & 9.43 & 2.62 & 1.492 & 0.972 & 0.053 & 0.77 & 6 & 94 & $<8$ & 61 & $<1$ & 29 & 47 & 7 & 21 & 47 \\
\hline 98DC-86 & 5.85 & 0.08 & 1.237 & 0.015 & 0.079 & 1.121 & $<2$ & 56 & $<8$ & 250 & $<1$ & $<10$ & 109 & 14 & 42 & 25 \\
\hline 98DC-88 & 5.06 & $<0.01$ & 0.008 & $<0.005$ & 0.006 & 0.009 & 10 & 85 & $<8$ & 133 & $<1$ & $<10$ & 5 & 6 & 4 & $<2$ \\
\hline 98DC-90 & 9.9 & 0.14 & 1.757 & 0.019 & 0.113 & 1.448 & $<2$ & $<10$ & $<8$ & 334 & $<1$ & 54 & 3 & 22 & 44 & 85 \\
\hline 98DC-92 & 9.28 & 0.24 & 0.399 & 0.028 & 0.043 & 0.585 & 397 & 140 & $<8$ & 36 & 1 & 64 & 1620 & $<5$ & 46 & $<2$ \\
\hline 98DC-94 & 7.84 & 0.1 & 0.135 & 0.035 & 0.06 & 0.609 & 757 & 182 & $<8$ & 113 & 1 & 58 & 1990 & 35 & 57 & $<2$ \\
\hline 98DC-96 & 27.6 & $<0.01$ & 0.012 & 0.006 & 0.005 & $<0.005$ & 49 & 644 & $<8$ & 11 & $<1$ & $<10$ & 7 & $<5$ & 10 & 5 \\
\hline 98DC-97 & 2.53 & $<0.01$ & $<0.005$ & $<0.005$ & $<0.005$ & $<0.005$ & 4 & 20 & $<8$ & 107 & $<1$ & $<10$ & 85 & $<5$ & 20 & 3 \\
\hline 98DC-99 & 6.36 & 0.77 & 2.631 & 0.017 & 0.054 & 0.671 & 8 & 646 & $<8$ & 92 & $<1$ & 32 & 224 & 13 & 26 & 19 \\
\hline 98DC-100 & 13 & 0.19 & 2.02 & 0.013 & 0.048 & 0.489 & 19 & 283 & $<8$ & 33 & $<1$ & 28 & 307 & 8 & 30 & 31 \\
\hline 98DC-101 & 6.04 & 0.96 & 0.43 & 0.045 & 0.037 & 0.032 & 98 & 83 & $<8$ & 212 & $<1$ & 17 & 156 & 9 & 46 & 7 \\
\hline 98DC-103 & 4.63 & 5.84 & 0.008 & 0.949 & 0.008 & 0.094 & $<2$ & 139 & $<8$ & 366 & 2 & $<10$ & $<2$ & 152 & $<2$ & $<2$ \\
\hline 98DC-104 & 4.51 & 5.66 & 0.007 & 0.571 & $<0.005$ & 0.071 & $<2$ & 208 & $<8$ & 229 & 2 & $<10$ & $<2$ & 62 & $<2$ & $<2$ \\
\hline 98DC-105 & 14.4 & 2.73 & 0.019 & 0.591 & $<0.005$ & 0.066 & $<2$ & 69 & $<8$ & 44 & 1 & $<10$ & 2 & 39 & 22 & $<2$ \\
\hline 98DC-107 & 6.99 & 3.57 & 0.009 & 1.333 & $<0.005$ & 0.085 & $<2$ & 479 & $<8$ & 187 & 2 & $<10$ & $<2$ & 87 & $<2$ & $<2$ \\
\hline 98ZA-01 & 23.6 & 0.08 & 0.467 & 0.008 & 0.241 & 0.006 & 14 & 858 & $<8$ & 13 & $<1$ & $<10$ & 16 & 10 & 3 & 3 \\
\hline 98ZA-02 & 4.86 & $<0.01$ & 0.148 & $<0.005$ & 0.028 & $<0.005$ & 4 & 1120 & $<8$ & 50 & $<1$ & 10 & 158 & 30 & $<2$ & $<2$ \\
\hline 98ZA-03 & 9.08 & $<0.01$ & 0.268 & $<0.005$ & 0.078 & $<0.005$ & 10 & 321 & $<8$ & 43 & $<1$ & $<10$ & 89 & 11 & $<2$ & $<2$ \\
\hline
\end{tabular}


Table 3. Re

\begin{tabular}{|c|c|c|c|c|c|c|c|c|c|c|c|c|c|c|c|c|}
\hline Sample \# & $\begin{array}{r}\text { C_ICP40 } \\
\text { Cu } \\
\text { ppm }\end{array}$ & $\begin{array}{r}\text { C_ICP40 } \\
\text { Eu } \\
\text { ppm }\end{array}$ & $\begin{array}{r}\text { C_ICP40 } \\
\text { Ga } \\
\text { ppm } \\
\end{array}$ & $\begin{array}{r}\text { C_ICP40 } \\
\text { Ho } \\
\text { ppm }\end{array}$ & $\begin{array}{r}\text { C_ICP40 } \\
\text { La } \\
\text { ppm }\end{array}$ & $\begin{array}{r}\text { C_ICP40 } \\
\text { Li } \\
\text { ppm }\end{array}$ & $\begin{array}{r}\text { C_ICP40 } \\
\text { Mn } \\
\text { ppm }\end{array}$ & $\begin{array}{r}\text { C_ICP40 } \\
\text { Mo } \\
\text { ppm } \\
\end{array}$ & $\begin{array}{r}\text { C_ICP40 } \\
\text { Nb } \\
\text { ppm }\end{array}$ & $\begin{array}{r}\text { C_ICP40 } \\
\text { Nd } \\
\text { ppm }\end{array}$ & $\begin{array}{r}\text { C_ICP40 } \\
\text { Ni } \\
\text { ppm } \\
\end{array}$ & $\begin{array}{r}\text { C_ICP40 } \\
\text { Pb } \\
\text { ppm }\end{array}$ & $\begin{array}{r}\text { C_ICP40 } \\
\text { Sc } \\
\text { ppm }\end{array}$ & $\begin{array}{r}\text { C_ICP40 } \\
\text { Sn } \\
\text { ppm }\end{array}$ & $\begin{array}{r}\text { C_ICP40 } \\
\text { Sr } \\
\text { ppm }\end{array}$ & $\begin{array}{r}\text { C_ICP40 } \\
\text { Ta } \\
\text { ppm } \\
\end{array}$ \\
\hline 98DC-09 & 122 & $<2$ & $<4$ & $<4$ & 2 & 17 & 1430 & $<2$ & 11 & 13 & 41 & $<4$ & 25 & $<5$ & 134 & $<40$ \\
\hline 98DC-13 & 21010 & $<2$ & $<4$ & $<4$ & $<2$ & 2 & 6550 & 2 & $<4$ & 17 & $<3$ & 11 & $<2$ & $<5$ & 17 & $<40$ \\
\hline 98DC-14 & 5280 & $<2$ & $<4$ & $<4$ & $<2$ & 3 & 8500 & 5 & $<4$ & 24 & 12 & 10 & $<2$ & $<5$ & 128 & $<40$ \\
\hline 98DC-20 & 26 & $<2$ & $<4$ & $<4$ & 4 & 12 & 12490 & $<2$ & 5 & 9 & 73 & 635 & 24 & $<5$ & 481 & $<40$ \\
\hline 98DC-22 & 75 & $<2$ & 34 & $<4$ & $<2$ & 3 & 73 & 37 & $<4$ & 33 & 267 & 23 & 23 & 12 & 5 & $<40$ \\
\hline 98DC-25 & 59 & $<2$ & 13 & $<4$ & 17 & 8 & 1140 & $<2$ & 6 & 12 & 114 & $<4$ & 22 & $<5$ & 312 & $<40$ \\
\hline 98DC-26 & 273 & 2 & 11 & $<4$ & 18 & 6 & 1780 & $<2$ & 14 & 26 & 8 & $<4$ & 23 & $<5$ & 1020 & $<40$ \\
\hline 98DC-29 & 1960 & 7 & $<4$ & $<4$ & 71 & $<2$ & 3320 & $<2$ & $<4$ & 53 & $<3$ & 4 & 3 & $<5$ & 516 & $<40$ \\
\hline 98DC-30 & 48 & $<2$ & 22 & $<4$ & 7 & 5 & 763 & $<2$ & 5 & $<9$ & 111 & $<4$ & 23 & $<5$ & 165 & $<40$ \\
\hline 98DC-32 & 77 & $<2$ & 15 & $<4$ & $<2$ & 13 & 1860 & $<2$ & $<4$ & 11 & 11 & 513 & 7 & $<5$ & 6 & $<40$ \\
\hline 98DC-34 & 427 & $<2$ & $<4$ & $<4$ & $<2$ & $<2$ & 4990 & $<2$ & $<4$ & 11 & 23 & 45500 & $<2$ & $<5$ & 96 & $<40$ \\
\hline 98DC-35 & 55 & $<2$ & $<4$ & $<4$ & $<2$ & $<2$ & 11020 & 3 & 8 & 19 & 35 & 2690 & $<2$ & $<5$ & 141 & $<40$ \\
\hline 98DC-36 & 30 & $<2$ & $<4$ & $<4$ & $<2$ & $<2$ & 4930 & 4 & $<4$ & 20 & 13 & 264 & $<2$ & $<5$ & 57 & $<40$ \\
\hline 98DC-37 & 120 & $<2$ & $<4$ & $<4$ & $<2$ & 2 & 3660 & 10 & $<4$ & 24 & 18 & 4030 & $<2$ & $<5$ & 47 & $<40$ \\
\hline 98DC-40 & 732 & $<2$ & $<4$ & $<4$ & $<2$ & $<2$ & 13 & $<2$ & $<4$ & $<9$ & 5 & 30 & $<2$ & $<5$ & $<2$ & $<40$ \\
\hline 98DC-41 & 13 & $<2$ & 11 & $<4$ & $<2$ & $<2$ & 124 & 31 & $<4$ & 11 & 6 & 60 & $<2$ & $<5$ & 6 & $<40$ \\
\hline 98DC-44 & 14220 & 2 & 23 & $<4$ & 38 & 3 & 346 & 9 & 15 & 47 & $<3$ & 6 & $<2$ & $<5$ & 973 & $<40$ \\
\hline 98DC-45 & 34750 & 2 & 18 & $<4$ & 51 & 3 & 175 & 31 & 15 & 49 & 4 & 13 & 3 & $<5$ & 162 & $<40$ \\
\hline 98DC-47 & 556 & 3 & 22 & $<4$ & $<2$ & 22 & 370 & 3 & 11 & 22 & 103 & $<4$ & 35 & $<5$ & 44 & $<40$ \\
\hline 98DC-49 & 193 & $<2$ & 15 & $<4$ & $<2$ & 6 & 2670 & 18 & $<4$ & 18 & 300 & 10 & 22 & $<5$ & 206 & $<40$ \\
\hline 98DC-53B & 9 & $<2$ & $<4$ & $<4$ & 6 & 10 & 20 & $<2$ & $<4$ & $<9$ & 13 & 7 & 4 & $<5$ & 3 & $<40$ \\
\hline 98DC-56 & 42 & $<2$ & 7 & $<4$ & 4 & 25 & 44 & 12 & $<4$ & 12 & 21 & 500 & 2 & $<5$ & 41 & $<40$ \\
\hline 98DC-58 & 28 & 2 & 7 & $<4$ & $<2$ & 11 & 31 & 12 & $<4$ & 35 & 10 & 1050 & $<2$ & 8 & 40 & $<40$ \\
\hline 98DC-60 & 19 & $<2$ & $<4$ & $<4$ & 2 & 12 & 2110 & 4 & 7 & $<9$ & 9 & 5 & 6 & $<5$ & 321 & $<40$ \\
\hline 98DC-85 & 372 & 2 & $<4$ & $<4$ & $<2$ & 33 & 3810 & 4 & 8 & 17 & 35 & 122 & 20 & $<5$ & 265 & $<40$ \\
\hline 98DC-86 & 316 & $<2$ & 17 & $<4$ & 2 & 23 & 2390 & $<2$ & 11 & 12 & 35 & 43 & 33 & $<5$ & 117 & $<40$ \\
\hline 98DC-88 & 132 & $<2$ & $<4$ & $<4$ & $<2$ & $<2$ & 23 & $<2$ & $<4$ & $<9$ & $<3$ & 33 & $<2$ & $<5$ & 151 & $<40$ \\
\hline 98DC-90 & 15 & 3 & 29 & $<4$ & 3 & 53 & 909 & $<2$ & 16 & 24 & 68 & $<4$ & 44 & $<5$ & 45 & $<40$ \\
\hline 98DC-92 & 640 & 3 & $<4$ & $<4$ & 3 & 8 & 6650 & $<2$ & $<4$ & 16 & 30 & 21180 & 17 & $<5$ & 20 & $<40$ \\
\hline 98DC-94 & 1100 & 3 & 19 & $<4$ & 19 & 10 & 804 & $<2$ & $<4$ & 25 & 29 & 51270 & 11 & 5 & 17 & $<40$ \\
\hline 98DC-96 & 55 & $<2$ & 14 & $<4$ & $<2$ & $<2$ & 283 & 7 & $<4$ & 29 & 33 & 2580 & $<2$ & 14 & 4 & $<40$ \\
\hline 98DC-97 & 16 & $<2$ & $<4$ & $<4$ & $<2$ & $<2$ & 31 & 38 & $<4$ & $<9$ & $<3$ & 1340 & $<2$ & $<5$ & $<2$ & $<40$ \\
\hline 98DC-99 & 280 & 3 & 14 & $<4$ & $<2$ & 54 & 1980 & $<2$ & 8 & 10 & 31 & 269 & 21 & $<5$ & 239 & $<40$ \\
\hline 98DC-100 & 481 & $<2$ & 29 & $<4$ & $<2$ & 60 & 1290 & $<2$ & $<4$ & 16 & 34 & 1240 & 17 & $<5$ & 106 & $<40$ \\
\hline 98DC-101 & 285 & 2 & $<4$ & $<4$ & $<2$ & 6 & 3260 & $<2$ & $<4$ & $<9$ & 67 & 28560 & 13 & $<5$ & 125 & $<40$ \\
\hline 98DC-103 & 3 & $<2$ & 23 & $<4$ & 64 & 14 & 5 & 3 & 19 & 65 & $<3$ & 67 & $<2$ & $<5$ & 12 & $<40$ \\
\hline 98DC-104 & $<2$ & $<2$ & 12 & $<4$ & 27 & 18 & 12 & 5 & 18 & 28 & $<3$ & 50 & $<2$ & $<5$ & 10 & $<40$ \\
\hline 98DC-105 & 9 & $<2$ & 22 & $<4$ & 14 & 18 & 20 & 12 & 15 & 30 & 5 & 34 & $<2$ & 10 & 8 & $<40$ \\
\hline 98DC-107 & 2 & $<2$ & 24 & $<4$ & 38 & 19 & $<4$ & 7 & 21 & 36 & $<3$ & 26 & $<2$ & $<5$ & 13 & $<40$ \\
\hline 98ZA-01 & 12570 & $<2$ & 10 & $<4$ & $<2$ & 13 & 1930 & 56 & $<4$ & 35 & $<3$ & 368 & $<2$ & 6 & 92 & $<40$ \\
\hline 98ZA-02 & 828 & $<2$ & $<4$ & $<4$ & 7 & 4 & 266 & 8 & $<4$ & 18 & 5 & 351 & $<2$ & $<5$ & 279 & $<40$ \\
\hline 98ZA-03 & 3690 & $<2$ & $<4$ & $<4$ & $<2$ & $<2$ & 2710 & 35 & $<4$ & 12 & 13 & 81 & $<2$ & $<5$ & 233 & $<40$ \\
\hline
\end{tabular}


Table 3. Re

\begin{tabular}{|c|c|c|c|c|c|c|c|c|}
\hline Sample \# & $\begin{array}{r}\text { C_ICP40 } \\
\text { Th }\end{array}$ & $\begin{array}{r}\text { C_ICP40 } \\
\text { U }\end{array}$ & $\begin{array}{r}\text { C_ICP40 } \\
\text { V }\end{array}$ & $\begin{array}{r}\text { C_ICP40 } \\
Y\end{array}$ & $\begin{array}{r}\text { C_ICP40 } \\
\text { Yb }\end{array}$ & $\begin{array}{r}\text { C_ICP40 } \\
\mathrm{Zn}\end{array}$ & $\begin{array}{r}\text { C_CO2 C } \\
\mathrm{CO} 2 \mathrm{C}\end{array}$ & $\begin{array}{l}\text { C_CO2 C } \\
\text { CRBNT_C }\end{array}$ \\
\hline & ppm & ppm & ppm & ppm & $\mathrm{ppm}$ & ppm & $\%$ & $\%$ \\
\hline 98DC-09 & $<6$ & $<100$ & 254 & 23 & 2 & 42 & & \\
\hline 98DC-13 & $<6$ & $<100$ & 27 & 7 & $<1$ & 906 & & \\
\hline 98DC-14 & $<6$ & $<100$ & 49 & 7 & $<1$ & 3230 & & \\
\hline 98DC-20 & $<6$ & $<100$ & 167 & 15 & 2 & 7670 & & \\
\hline 98DC-22 & $<6$ & 197 & 242 & 4 & 2 & 16 & & \\
\hline 98DC-25 & $<6$ & $<100$ & 184 & 14 & 2 & 48 & & \\
\hline 98DC-26 & $<6$ & $<100$ & 384 & 19 & 3 & 56 & & \\
\hline 98DC-29 & $<6$ & $<100$ & 10 & 49 & 3 & 2980 & & \\
\hline 98DC-30 & $<6$ & $<100$ & 187 & 15 & 2 & 37 & & \\
\hline 98DC-32 & $<6$ & $<100$ & 55 & 5 & 1 & 160660 & & \\
\hline 98DC-34 & $<6$ & $<100$ & 22 & 4 & $<1$ & 91370 & & \\
\hline 98DC-35 & $<6$ & $<100$ & 31 & 6 & $<1$ & 8240 & 31.4 & 8.57 \\
\hline 98DC-36 & $<6$ & $<100$ & 28 & 4 & $<1$ & 1880 & & \\
\hline 98DC-37 & $<6$ & $<100$ & 35 & 7 & $<1$ & 26780 & & \\
\hline 98DC-40 & $<6$ & $<100$ & 3 & $<2$ & $<1$ & 814 & & \\
\hline 98DC-41 & $<6$ & $<100$ & 23 & $<2$ & $<1$ & 66 & & \\
\hline 98DC-44 & 9 & $<100$ & 34 & 47 & 3 & 68 & & \\
\hline 98DC-45 & 17 & $<100$ & 35 & 17 & 1 & 139 & & \\
\hline 98DC-47 & $<6$ & $<100$ & 374 & 13 & 2 & 95 & & \\
\hline 98DC-49 & $<6$ & $<100$ & 513 & 8 & 2 & 87 & & \\
\hline 98DC-53B & $<6$ & $<100$ & 37 & $<2$ & $<1$ & 38 & & \\
\hline 98DC-56 & $<6$ & $<100$ & 78 & 6 & 1 & 10150 & & \\
\hline 98DC-58 & 11 & 161 & 51 & 11 & $<1$ & 2950 & & \\
\hline 98DC-60 & $<6$ & $<100$ & 46 & 13 & 2 & 86 & & \\
\hline 98DC-85 & $<6$ & $<100$ & 250 & 17 & 2 & 9270 & & \\
\hline 98DC-86 & $<6$ & $<100$ & 343 & 18 & 3 & 12970 & & \\
\hline 98DC-88 & $<6$ & $<100$ & 7 & $<2$ & $<1$ & 1510 & & \\
\hline 98DC-90 & $<6$ & $<100$ & 483 & 20 & 2 & 110 & & \\
\hline 98DC-92 & $<6$ & $<100$ & 117 & 8 & $<1$ & 151550 & & \\
\hline 98DC-94 & $<6$ & $<100$ & 150 & 8 & 1 & 169480 & & \\
\hline 98DC-96 & 8 & 232 & 29 & $<2$ & $<1$ & 4670 & & \\
\hline 98DC-97 & $<6$ & $<100$ & 3 & $<2$ & $<1$ & 20100 & & \\
\hline 98DC-99 & $<6$ & $<100$ & 250 & 15 & 3 & 45220 & & \\
\hline 98DC-100 & $<6$ & $<100$ & 198 & 12 & 2 & 60940 & & \\
\hline 98DC-101 & $<6$ & $<100$ & 117 & 14 & 2 & 37190 & & \\
\hline 98DC-103 & 27 & $<100$ & 9 & 32 & 4 & 177 & & \\
\hline 98DC-104 & 17 & $<100$ & 5 & 29 & 3 & 216 & & \\
\hline 98DC-105 & 16 & $<100$ & 15 & 37 & 4 & 64 & & \\
\hline 98DC-107 & 20 & $<100$ & 9 & 19 & 2 & 62 & & \\
\hline 98ZA-01 & $<6$ & 117 & 28 & 24 & 1 & 9280 & & \\
\hline 98ZA-02 & $<6$ & $<100$ & 14 & 7 & $<1$ & 52000 & & \\
\hline 98ZA-03 & $<6$ & $<100$ & 14 & 5 & $<1$ & 34150 & & \\
\hline
\end{tabular}




\begin{tabular}{|c|c|c|c|c|c|}
\hline Sample \# & Location & Rock type & Description & Age & Unit \\
\hline $98 Z A-04$ & Frenchie & qtz-rich massive sulfide & qtz-py rich layer over massive layer at $45 \mathrm{~m}$ downstream & Triassic (?) & \\
\hline 98ZA-07 & Lost Zarembo & semi-massive sulfide & 1.2-m-thick po-py-cpy band in siliceous greenschist & Triassic(?) & Trhsv \\
\hline 98ZA-09 & Round Point & semi-massive sulfide & 15-cm-thick py-sph-cpy-rich band in py-ser-chl schist & Triassic(?) & Trhsv \\
\hline $98 Z A-11 B$ & Round Point & semi-massive sulfide & $2.5 \mathrm{~cm}$ band of semi-massive sulfide in qtz-musc schist & Triassic(?) & Trhsv \\
\hline $98 Z A-13$ & SE Zarembo siliceous breccia & qtz breccia & siliceous vent (?) breccia in mouth of creek & Tertiary(?) & Tma \\
\hline $98 Z A-14$ & SE Zarembo siliceous breccia & argillite breccia & argillite breccia or conglomerate with py-rich matrix; FLOAT & Tertiary(?) & Trha \\
\hline $98 Z A-16$ & Snow Pass Fluorite & fluorite-qtz-py vein & py-rich qtz-fluorite vein & Tertiary-Quaternary & \\
\hline $98 Z A-17$ & South shore, Zarembo Island & pyritic meta-sediment & disseminated py dark gray to black meta-sediment; FLOAT & & \\
\hline ZAR\#1-10 & Frenchie, $(152 ')$ & qtz-fluorite vein & qtz vein with pale green fluorite in vuggy qtz-rich rock & Tertiary-Quaternary & \\
\hline ZAR\#2-04 & Frenchie, (106') & pyritic tuff & $15 \mathrm{~cm}$ interbed of pyritic green tuffaceous phyllite in argillite & Triassic(?) & Trhsv \\
\hline 92ZA-04 & Bay Point U-Th-REE occurrence & qtz-carb-sulfide vein & orange alt'd qtz-carb vein with sph, gn (?) & & Stpc \\
\hline 92ZA-05 & Bay Point U-Th-REE occurrence & mineralized graywacke & laminated graywacke with sulfides on fractures & & Stpc \\
\hline $92 Z A-06$ & Bay Point U-Th-REE occurrence & carbonatite & orange carb veined, dark gray carbonatite & & Stpc \\
\hline 92ZA-07 & Bay Point U-Th-REE occurrence & carbonatite-metaturbidite & highly carbonate alt'd metaturbidite & & Stpc \\
\hline $92 Z A-08$ & Bay Point U-Th-REE occurrence & mineralized breccia & orange alt'd carb breccia & & Stpc \\
\hline 92ZA-09 & Bay Point U-Th-REE occurrence & basalt & fresh biotite (augite?) bearing basalt, cc-veined & & Stpc \\
\hline $92 Z A-10$ & Bay Point U-Th-REE occurrence & marble & clast of white marble in carb matrix & & Stpc \\
\hline $92 Z A-11$ & Bay Point U-Th-REE occurrence & qtz-carb-sulfide vein & banded py-gn in white qtz-carb & & Stpc \\
\hline $92 Z A-12$ & Bay Point U-Th-REE occurrence & carbonatite & orange carb, margin of carbonate vein & & Stpc \\
\hline $92 Z A-13$ & Bay Point U-Th-REE occurrence & basaltic dike & purple basalt with orange cc -cpy & & Stpc \\
\hline 93DC-07 & St. John's Fluorite & qtz-fluorite veins & qtz-fluorite veins & & \\
\hline 93DC-08 & Maid of Mexico $50 \mathrm{~m}$ above portal & mineralized felsic tuff & felsic tuff with qtz-carb-py-ser-fuch & Cretaceous & Trha \\
\hline 93DC-09 & Maid of Mexico $50 \mathrm{~m}$ above portal & mineralized felsic tuff & felsic tuff with qtz-carb-py-ser-fuch & Cretaceous & Trha \\
\hline 93DC-10 & Maid of Mexico $50 \mathrm{~m}$ above portal & mineralized qtz & qtz with cpy-py-carb-ser-fuch & Cretaceous & Trha \\
\hline 93DC-11 & Maid of Mexico $50 \mathrm{~m}$ above portal & mineralized felsic tuff & felsic tuff sulfide rich & Cretaceous & Trha \\
\hline 93DC-16 & Helen S & massive py & massive py in phyllite & Triassic(?) & Trhv \\
\hline 93DC-17 & Helen S & massive qtz-py & massive qtz-py & Triassic(?) & \\
\hline 93DC-18 & Helen S & phyllite & selected qtz-py rich phyllite & Triassic(?) & Trhv \\
\hline 93DC-19 & Little Castle Is. west side & qtz-carb breccia & orange alt'd qtz-carb breccia; FLOAT & Triassic(?) & \\
\hline 93DC-20 & Little Castle Is. west side & massive barite & massive barite; FLOAT & Triassic(?) & \\
\hline 93DC-24B & Little Castle Is. south of rubble pad & basalt & mafic volcanic next to shear & Triassic(?) & Trhv \\
\hline 93DC-26 & Big Castle Is. south tip & basalt & cc veined alt'd basalt from shear & Triassic(?) & Trhv \\
\hline 93DC-42 & Rookery Island & qtz-carb-sulfide vein & $5 \mathrm{~cm}$ wide qtz-carb-sulfide vein & Triassic(?) & \\
\hline 93ZA-14 & Frenchie, at portal & massive sulfide & massive sulfide & Triassic(?) & \\
\hline 93ZA-15 & Frenchie, $75 \mathrm{~m}$ downstream & massive sulfide & massive sulfide & Triassic(?) & \\
\hline 93ZA-16 & Frenchie, $150-200 \mathrm{~m}$ downstream & massive sulfide & massive sulfide & Triassic(?) & \\
\hline
\end{tabular}

Key: qtz=quartz, kspar=potassium feldspar, musc=muscovite, ser=sericite, fuch=fuchsite, $\mathrm{chl}=$ chlorite, $\mathrm{cc}=$ calcite, carb=carbonate, $\mathrm{hb}=\mathrm{hornblende,} \mathrm{py}=\mathrm{pyrite}, \mathrm{po}=\mathrm{pyrrhotite}$

$\mathrm{sph}=$ sphalerite, gn=galena, $\mathrm{cpy}=$ chalcopyrite, Sec.=section, $\mathrm{km}=$ kilometers $\mathrm{m}=$ meters, $\mathrm{cm}=$ centimeters, VMS=volcanogenic massive sulfide, alt'd=altered, $\mathrm{x}$-cut=cross-cut,

porph=porphyritic, aph=aphanitic. 


\begin{tabular}{|c|c|c|c|c|c|c|c|c|c|c|c|c|c|c|c|c|}
\hline Sample \# & DD Lat & DD Long & $\begin{array}{r}\text { C_Au FA } \\
\text { Au } \\
\text { ppm }\end{array}$ & $\begin{array}{r}\text { CVAA } \\
\text { Hg } \\
\mathrm{ppm} \\
\end{array}$ & $\begin{array}{r}\text { C_ICP10 } \\
\text { Ag } \\
\text { ppm } \\
\end{array}$ & $\begin{array}{r}\text { C_ICP10 } \\
\text { As } \\
\text { ppm } \\
\end{array}$ & $\begin{array}{r}\text { C_ICP10 } \\
\text { Au } \\
\text { ppm } \\
\end{array}$ & $\begin{array}{r}\text { C_ICP10 } \\
\text { Bi } \\
\text { ppm } \\
\end{array}$ & $\begin{array}{r}\text { C_ICP10 } \\
\text { Cd } \\
\text { ppm } \\
\end{array}$ & $\begin{array}{r}\text { C_ICP10 } \\
\text { Cu } \\
\text { ppm } \\
\end{array}$ & $\begin{array}{r}\text { C_ICP10 } \\
\text { Mo } \\
\text { ppm } \\
\end{array}$ & $\begin{array}{r}\text { C_ICP10 } \\
\text { Pb } \\
\text { ppm } \\
\end{array}$ & $\begin{array}{r}\text { C_ICP10 } \\
\text { Sb } \\
\text { ppm } \\
\end{array}$ & $\begin{array}{r}\text { C_ICP10 } \\
\text { Zn } \\
\text { ppm }\end{array}$ & $\begin{array}{r}\text { C_ICP40 } \\
\text { AI } \\
\% \\
\end{array}$ & $\begin{array}{r}\text { C_ICP40 } \\
\text { Ca } \\
\% \\
\end{array}$ \\
\hline 98ZA-04 & 56.4167 & 132.9500 & 0.058 & 0.19 & 5.9 & 39 & $<0.1$ & $<1$ & 102 & 135 & 3.9 & $>6000$ & 5 & $>500$ & 7.298 & $\overline{0.008}$ \\
\hline 98ZA-07 & 56.3667 & 132.9000 & 0.123 & 0.03 & 14.9 & $<1$ & 0.3 & $<1$ & 82.8 & $>500$ & 1.7 & 1630 & $<1$ & $>500$ & 0.16 & 0.317 \\
\hline 98ZA-09 & 56.2667 & 132.7000 & 0.052 & 0.28 & 9.7 & $<1$ & $<0.1$ & 2 & 61.8 & $>500$ & 1.6 & 23 & 3 & $>500$ & 3.009 & 0.058 \\
\hline 98ZA-11B & 56.2667 & 132.7000 & 0.017 & 0.21 & 4.3 & 7 & $<0.1$ & $<1$ & 59.1 & 58 & 1.6 & 4320 & 9 & $>500$ & 8.378 & 0.206 \\
\hline 98ZA-13 & 56.2667 & 132.6667 & 0.024 & 0.03 & 0.3 & 18 & $<0.1$ & $<1$ & 0.24 & 9.58 & 3 & 15 & 7 & 93 & 1.892 & 0.038 \\
\hline 98ZA-14 & 56.2500 & 132.7000 & 0.008 & $<0.02$ & $<0.08$ & $<1$ & $<0.1$ & $<1$ & 0.09 & 77.8 & 0.2 & 4 & $<1$ & 132 & 8.111 & 1.167 \\
\hline 98ZA-16 & 56.2667 & 132.9333 & 0.027 & $<0.02$ & $<0.08$ & 36 & $<0.1$ & $<1$ & 0.38 & 4.4 & 1.8 & 10 & $<1$ & 153 & 6.794 & 2.892 \\
\hline $98 Z A-17$ & 56.2500 & 132.7500 & $<0.005$ & $<0.02$ & 0.1 & $<1$ & $<0.1$ & $<1$ & 0.11 & 69.1 & 0.5 & 3 & $<1$ & 83.1 & 7.962 & 8.433 \\
\hline ZAR\#1-10 & 56.4167 & 132.9500 & 0.026 & $<0.02$ & 1 & 35 & $<0.1$ & $<1$ & 0.35 & 228 & 5.1 & 8 & 3 & 56 & 2.639 & 10.7 \\
\hline ZAR\#2-04 & 56.4167 & 132.9500 & 0.013 & $<0.02$ & 0.3 & 21 & $<0.1$ & $<1$ & $<0.05$ & 172 & 0.3 & 1 & $<1$ & 72.3 & 9.245 & 0.894 \\
\hline 92ZA-04 & 56.3167 & 133.1667 & N 0.002 & N 0.02 & N 0.067 & N 0.67 & N 0.10 & N 0.67 & 26 & 21 & 5.2 & 1300 & N 0.67 & $>1800$ & 0.55 & 19 \\
\hline 92ZA-05 & 56.3167 & 133.1667 & N 0.002 & 0.10 & N 0.067 & 7.5 & N 0.10 & N 0.67 & 2.8 & 38 & 3.5 & 190 & N 0.67 & 970 & 9.2 & 2.4 \\
\hline 92ZA-06 & 56.3167 & 133.1667 & N 0.002 & 0.04 & N 0.067 & 1.3 & N 0.10 & N 0.67 & 0.069 & 9.5 & 0.67 & 4.3 & N 0.67 & 23 & 7.0 & 6.9 \\
\hline 92ZA-07 & 56.3167 & 133.1667 & 0.008 & N 0.02 & N 0.067 & 2.7 & N 0.10 & N 0.67 & 0.062 & 4.3 & 2.4 & 2.8 & N 0.67 & 29 & 3.1 & 15 \\
\hline 92ZA-08 & 56.3167 & 133.1667 & N 0.002 & N 0.02 & N 0.067 & N 0.67 & N 0.10 & N 0.67 & N 0.050 & 0.57 & 0.24 & N 0.67 & N 0.67 & 30 & 0.36 & 20 \\
\hline 92ZA-09 & 56.3167 & 133.1667 & N 0.002 & N 0.02 & 0.11 & 1.1 & N 0.10 & N 0.67 & 0.15 & 87 & 0.30 & 38 & N 0.67 & 140 & 8.3 & 5.8 \\
\hline $92 Z A-10$ & 56.3167 & 133.1667 & N 0.002 & N 0.02 & N 0.067 & N 0.67 & N 0.10 & N 0.67 & 0.16 & 6.7 & 0.30 & 21 & N 0.67 & 29 & 1.6 & 30 \\
\hline 92ZA-11 & 56.3167 & 133.1667 & N 0.002 & N 0.02 & 0.43 & 1.8 & N 0.10 & N 0.67 & 1.4 & 62 & 6.9 & 27 & N 0.67 & 130 & 0.1 & 30 \\
\hline 92ZA-12 & 56.3167 & 133.1667 & & & N 0.067 & N 0.67 & N 0.10 & N 0.67 & 0.22 & 11 & 42 & 3.3 & N 0.67 & 260 & 4.1 & 15 \\
\hline $92 Z A-13$ & 56.31667 & 133.1667 & & & - & - & - & - & - & - & - & - & - & - & 6.5 & 7.9 \\
\hline 93DC-07 & 56.4167 & 132.9500 & & & - & - & - & - & - & - & - & - & - & - & 3.3 & 5.3 \\
\hline 93DC-08 & 56.5500 & 133.0167 & & & N 0.067 & N 1.0 & N 0.10 & N 1.0 & N 0.050 & 78 & 0.16 & N 1.0 & N 1.0 & 83 & 8.0 & 9.4 \\
\hline 93DC-09 & 56.5500 & 133.0167 & & & 0.13 & 180 & N 0.10 & N 1.0 & 0.19 & 1.8 & N 0.10 & 2.0 & N 1.0 & 57 & 5.5 & 10 \\
\hline $93 \mathrm{DC}-10$ & 56.5500 & 133.0167 & & & 0.62 & 4.8 & 0.62 & N 1.0 & 1.6 & 210 & 0.19 & 7.9 & N 1.0 & 80 & 1.2 & 9.8 \\
\hline 93DC-11 & 56.5500 & 133.0167 & & & 1.6 & N 1.0 & 1.1 & N 1.0 & 13 & 7.3 & N 0.10 & 610 & N 1.0 & 290 & 2.1 & 11 \\
\hline 93DC-16 & 56.5667 & 133.0500 & & & 1.4 & 24 & N 0.10 & N 1.0 & 7.2 & 4.1 & 0.68 & 160 & 2.7 & 2200 & 1.5 & 3.6 \\
\hline 93DC-17 & 56.5667 & 133.0500 & & & 5.9 & 12 & N 0.10 & N 1.0 & 0.33 & 3.5 & N 0.10 & 550 & 9.0 & 150 & 0.02 & 0.01 \\
\hline 93DC-18 & 56.5667 & 133.0500 & & & 4.8 & 46 & N 0.10 & N 1.0 & 13 & 18 & 1.1 & 1300 & 3.2 & $>2700$ & 2.3 & 13 \\
\hline 93DC-19 & 56.6500 & 133.1667 & & & N 0.067 & N 1.0 & N 0.10 & N 1.0 & N 0.050 & 0.33 & 0.11 & 4.0 & N 1.0 & 15 & 0.19 & 13 \\
\hline 93DC-20 & 56.6500 & 133.1667 & & & 21 & N 10 & N 1.0 & N 10 & 63 & 250 & 2.9 & 3500 & 21 & 6800 & $<0.01$ & 0.02 \\
\hline 93DC-24B & 56.6500 & 133.1500 & & & 14 & 66 & N 0.10 & N 1.0 & 46 & 300 & 1.8 & 2200 & 14 & $>2700$ & 0.02 & 0.06 \\
\hline 93DC-26 & 56.6500 & 133.1500 & & & N 0.067 & 4.5 & N 0.10 & N 1.0 & 0.17 & 37 & 0.11 & 3.9 & N 1.0 & 50 & 1.8 & 16 \\
\hline 93DC-42 & 56.6833 & 133.2000 & & & 0.84 & N 1.0 & 0.22 & N 1.0 & 0.095 & 32 & N 0.10 & 1.1 & N 1.0 & 15 & 0.74 & 12 \\
\hline 93ZA-14 & 56.4167 & 132.9500 & & & 7.3 & N 10 & N 1.0 & N 10 & 24 & 3200 & 2.7 & 68 & N 10 & 5400 & 0.11 & 3.5 \\
\hline 93ZA-15 & 56.4167 & 132.9500 & & & 10 & N 1.0 & N 0.10 & N 1.0 & 130 & 450 & 1.9 & 600 & N 1.0 & $>2700$ & 0.01 & 0.32 \\
\hline $93 Z A-16$ & 56.4167 & 132.9500 & & & 2.1 & N 1.0 & N 0.10 & N 1.0 & 170 & 360 & 2.0 & 170 & N 1.0 & $>2700$ & 0.06 & 2.6 \\
\hline
\end{tabular}

$\mathrm{sph}=$ sphale

porph=porp 


\begin{tabular}{|c|c|c|c|c|c|c|c|c|c|c|c|c|c|c|c|c|}
\hline Sample \# & $\begin{array}{r}\text { C_ICP40 } \\
\text { Fe } \\
\% \\
\end{array}$ & $\begin{array}{r}\text { C_ICP40 } \\
\text { K } \\
\% \\
\end{array}$ & $\begin{array}{r}\text { C_ICP40 } \\
\text { Mg } \\
\% \\
\end{array}$ & $\begin{array}{r}\text { C_ICP40 } \\
\mathrm{Na} \\
\% \\
\end{array}$ & $\begin{array}{r}\text { C_ICP40 } \\
\text { P } \\
\% \\
\end{array}$ & $\begin{array}{r}\text { C_ICP40 } \\
\text { Ti } \\
\% \\
\end{array}$ & $\begin{array}{r}\text { C_ICP40 } \\
\text { Ag } \\
\text { ppm } \\
\end{array}$ & $\begin{array}{r}\text { C_ICP40 } \\
\text { As } \\
\text { ppm } \\
\end{array}$ & $\begin{array}{r}\text { C_ICP40 } \\
\text { Au } \\
\text { ppm } \\
\end{array}$ & $\begin{array}{r}\text { C_ICP40 } \\
\text { Ba } \\
\text { ppm } \\
\end{array}$ & $\begin{array}{r}\text { C_ICP40 } \\
\text { Be } \\
\text { ppm } \\
\end{array}$ & $\begin{array}{r}\text { C_ICP40 } \\
\text { Bi } \\
\text { ppm } \\
\end{array}$ & $\begin{array}{r}\text { C_ICP40 } \\
\text { Cd } \\
\text { ppm } \\
\end{array}$ & $\begin{array}{r}\text { C_ICP40 } \\
\text { Ce } \\
\text { ppm } \\
\end{array}$ & $\begin{array}{r}\text { C_ICP40 } \\
\text { Co } \\
\text { ppm } \\
\end{array}$ & $\begin{array}{r}\text { C_ICP40 } \\
\text { Cr } \\
\text { ppm } \\
\end{array}$ \\
\hline 98ZA-04 & 3.34 & 7.38 & 0.164 & 0.196 & 0.008 & 0.054 & 4 & 173 & $<8$ & 96 & 2 & $<10$ & 71 & 52 & $<2$ & $<2$ \\
\hline 98ZA-07 & 14.7 & 0.03 & 0.114 & 0.006 & 0.056 & $<0.005$ & 13 & $<10$ & $<8$ & 62 & $<1$ & $<10$ & 69 & 12 & 23 & 4 \\
\hline 98ZA-09 & 7.8 & 2.55 & 0.157 & 0.234 & 0.086 & 0.033 & 11 & 26 & $<8$ & 123 & $<1$ & $<10$ & 62 & 56 & 10 & 2 \\
\hline 98ZA-11B & 5.9 & 2.91 & 1.348 & 3.244 & 0.01 & 0.082 & 2 & 22 & $<8$ & 161 & 5 & $<10$ & 37 & 142 & $<2$ & $<2$ \\
\hline 98ZA-13 & 0.82 & 0.56 & 0.069 & 0.043 & 0.008 & 0.035 & $<2$ & $<10$ & $<8$ & 150 & 2 & $<10$ & $<2$ & 20 & $<2$ & $<2$ \\
\hline 98ZA-14 & 5.72 & 0.99 & 1.919 & 1.989 & 0.087 & 0.587 & $<2$ & $<10$ & $<8$ & 1110 & $<1$ & 13 & $<2$ & 28 & 19 & 15 \\
\hline 98ZA-16 & 3.19 & 3.85 & 0.364 & 2.467 & 0.016 & 0.213 & $<2$ & 43 & 8 & 249 & 1 & $<10$ & $<2$ & 69 & $<2$ & $<2$ \\
\hline 98ZA-17 & 5.85 & 0.29 & 1.483 & 0.637 & 0.063 & 0.592 & $<2$ & $<10$ & $<8$ & 176 & $<1$ & 11 & $<2$ & 38 & 18 & 27 \\
\hline ZAR\#1-10 & 4.61 & 0.85 & 0.655 & 0.015 & 0.033 & 0.179 & $<2$ & 99 & $<8$ & 311 & 1 & $<10$ & $<2$ & 13 & 9 & 14 \\
\hline ZAR\#2-04 & 7.61 & 3.02 & 4.793 & 0.972 & 0.142 & 0.591 & $<2$ & 34 & $<8$ & 166 & 2 & 18 & 3 & 35 & 32 & 105 \\
\hline 92ZA-04 & 10 & 0.65 & 6.2 & 0.1 & 0.03 & 0.01 & $<4$ & $<20$ & $<20$ & 51 & $<2$ & $<20$ & 27 & 650 & 20 & $<2$ \\
\hline 92ZA-05 & 4.4 & 1.5 & 0.96 & 5.5 & 0.05 & 0.25 & $<4$ & $<20$ & $<20$ & 240 & 2 & $<20$ & $<4$ & 60 & 10 & 10 \\
\hline 92ZA-06 & 4.6 & 1.8 & 2.0 & 4.6 & 0.1 & 0.1 & $<4$ & $<20$ & $<20$ & 300 & $<2$ & $<20$ & $<4$ & 56 & 8 & 10 \\
\hline 92ZA-07 & 7.6 & 0.05 & 5.0 & 2.6 & 0.03 & 0.04 & $<4$ & $<20$ & $<20$ & 23 & $<2$ & $<20$ & $<4$ & 43 & 9 & 9 \\
\hline 92ZA-08 & 11 & 0.1 & 6.4 & 0.28 & $<0.01$ & 0.01 & $<4$ & $<20$ & $<20$ & 7 & $<2$ & $<20$ & $<4$ & 20 & 6 & 3 \\
\hline 92ZA-09 & 5.6 & 2.0 & 2.7 & 4.2 & 0.30 & 0.50 & $<4$ & $<20$ & $<20$ & 690 & 5 & $<20$ & $<4$ & 150 & 24 & 53 \\
\hline 92ZA-10 & 2.5 & 0.07 & 0.56 & 2.0 & 0.06 & 0.09 & $<4$ & $<20$ & $<20$ & 490 & $<2$ & $<20$ & $<4$ & 340 & 4 & 20 \\
\hline 92ZA-11 & 8.2 & 0.1 & 0.69 & 0.05 & 0.45 & 0.02 & $<4$ & $<20$ & $<20$ & 200 & $<2$ & $<20$ & $<4$ & 490 & 70 & 2 \\
\hline 92ZA-12 & 11 & 2.5 & 4.6 & 0.31 & 0.35 & 0.43 & $<2$ & $<10$ & $<8$ & 260 & 3 & $<10$ & $<2$ & 120 & 12 & 120 \\
\hline 92ZA-13 & 11 & 3.7 & 4.2 & 2.3 & 0.62 & 0.89 & $<2$ & $<10$ & $<8$ & 250 & $<1$ & $<10$ & $<2$ & 280 & 18 & 140 \\
\hline 93DC-07 & 0.77 & 1.2 & 0.14 & 0.64 & $<0.01$ & 0.04 & $<4$ & $<20$ & $<20$ & 220 & $<2$ & $<20$ & $<4$ & 52 & 2 & $<2$ \\
\hline 93DC-08 & 5.7 & 0.74 & 3.0 & 0.07 & 0.15 & 0.15 & $<4$ & $<20$ & $<20$ & 430 & $<2$ & $<20$ & $<4$ & 16 & 33 & 8 \\
\hline 93DC-09 & 3.9 & 0.83 & 4.3 & 0.05 & 0.13 & 0.05 & $<4$ & 140 & $<20$ & 200 & $<2$ & $<20$ & $<4$ & 14 & 51 & 470 \\
\hline 93DC-10 & 2.8 & 0.55 & 1.8 & 0.02 & 0.06 & 0.02 & $<4$ & $<20$ & $<20$ & 150 & $<2$ & $<20$ & $<4$ & $<8$ & 8 & 51 \\
\hline 93DC-11 & 3.7 & 0.72 & 3.5 & 0.03 & 0.05 & 0.03 & 55 & 24 & 65 & 190 & $<2$ & $<20$ & 230 & $<8$ & 19 & 130 \\
\hline 93DC-16 & 24 & 0.64 & 0.19 & 0.01 & 0.01 & 0.17 & 29 & 520 & $<20$ & 12 & $<2$ & $<20$ & 120 & $<8$ & 29 & 4 \\
\hline 93DC-17 & 37 & $<0.02$ & $<0.01$ & $<0.01$ & $<0.01$ & $<0.01$ & 110 & 400 & $<20$ & 8 & $<2$ & $<20$ & $<4$ & $<8$ & 29 & $<2$ \\
\hline 93DC-18 & 9.0 & 0.96 & 0.28 & 0.02 & 0.02 & 0.25 & 11 & 210 & $<20$ & 49 & $<2$ & $<20$ & 16 & 10 & 30 & 10 \\
\hline 93DC-19 & 3.3 & $<0.02$ & 3.8 & 0.01 & $<0.01$ & $<0.01$ & $<4$ & $<20$ & $<20$ & 400 & $<2$ & $<20$ & $<4$ & $<8$ & 6 & 8 \\
\hline 93DC-20 & 0.46 & $<0.02$ & $<0.01$ & $<0.01$ & $<0.01$ & $<0.01$ & 27 & 27 & $<20$ & 380 & $<2$ & $<20$ & 99 & $<8$ & $<2$ & $<2$ \\
\hline 93DC-24B & 4.2 & $<0.02$ & $<0.01$ & $<0.01$ & $<0.01$ & $<0.01$ & 23 & 150 & $<20$ & 100 & $<2$ & $<20$ & 68 & $<8$ & 5 & $<2$ \\
\hline 93DC-26 & 6.4 & 0.13 & 5.5 & 0.05 & 0.02 & 0.28 & $<4$ & $<20$ & $<20$ & 750 & $<2$ & $<20$ & $<4$ & $<8$ & 18 & 52 \\
\hline 93DC-42 & 2.3 & 0.55 & 0.14 & 0.03 & 0.01 & $<0.01$ & $<4$ & $<20$ & $<20$ & 470 & $<2$ & $<20$ & $<4$ & $<8$ & 13 & $<2$ \\
\hline 93ZA-14 & 14 & $<0.02$ & 0.13 & $<0.01$ & 0.03 & $<0.01$ & 18 & 240 & $<20$ & 28 & $<2$ & $<20$ & 62 & 32 & 4 & $<2$ \\
\hline 93ZA-15 & 5.7 & $<0.02$ & 0.01 & $<0.01$ & 0.01 & $<0.01$ & 23 & 71 & $<20$ & 45 & $<2$ & $<20$ & 310 & 9 & 8 & $<2$ \\
\hline 93ZA-16 & 2.1 & $<0.02$ & 0.07 & $<0.01$ & $<0.01$ & $<0.01$ & 6 & 25 & $<20$ & 83 & $<2$ & $<20$ & 270 & 65 & 2 & $<2$ \\
\hline
\end{tabular}

Key: qtz=qu

sph=sphale

porph=porp 


\begin{tabular}{|c|c|c|c|c|c|c|c|c|c|c|c|c|c|c|c|c|}
\hline Sample \# & $\begin{array}{r}\text { C_ICP40 } \\
\text { Cu } \\
\text { ppm }\end{array}$ & $\begin{array}{r}\text { C_ICP40 } \\
\text { Eu } \\
\text { ppm } \\
\end{array}$ & $\begin{array}{r}\text { C_ICP40 } \\
\text { Ga } \\
\text { ppm } \\
\end{array}$ & $\begin{array}{r}\text { C_ICP40 } \\
\text { Ho } \\
\text { ppm } \\
\end{array}$ & $\begin{array}{r}\text { C_ICP40 } \\
\text { La } \\
\text { ppm } \\
\end{array}$ & $\begin{array}{r}\text { C_ICP40 } \\
\text { Li } \\
\text { ppm } \\
\end{array}$ & $\begin{array}{r}\text { C_ICP40 } \\
\text { Mn } \\
\text { ppm }\end{array}$ & $\begin{array}{r}\text { C_ICP40 } \\
\text { Mo } \\
\text { ppm } \\
\end{array}$ & $\begin{array}{r}\text { C_ICP40 } \\
\text { Nb } \\
\text { ppm }\end{array}$ & $\begin{array}{r}\text { C_ICP40 } \\
\text { Nd } \\
\text { ppm } \\
\end{array}$ & $\begin{array}{r}\text { C_ICP40 } \\
\mathrm{Ni} \\
\mathrm{ppm}\end{array}$ & $\begin{array}{r}\text { C_ICP40 } \\
\text { Pb } \\
\text { ppm } \\
\end{array}$ & $\begin{array}{r}\text { C_ICP40 } \\
\text { Sc } \\
\text { ppm } \\
\end{array}$ & $\begin{array}{r}\text { C_ICP40 } \\
\text { Sn } \\
\text { ppm } \\
\end{array}$ & $\begin{array}{r}\text { C_ICP40 } \\
\text { Sr } \\
\text { ppm } \\
\end{array}$ & $\begin{array}{r}\text { C_ICP40 } \\
\text { Ta } \\
\text { ppm } \\
\end{array}$ \\
\hline 98ZA-04 & 121 & 2 & 24 & $<4$ & 16 & 6 & 30 & 12 & 11 & 36 & 6 & 8240 & $<2$ & $<5$ & 82 & $<40$ \\
\hline 98ZA-07 & 1550 & $<2$ & 9 & $<4$ & $<2$ & 3 & 157 & 20 & $<4$ & 21 & 17 & 1380 & $<2$ & 7 & 113 & $<40$ \\
\hline 98ZA-09 & 3800 & $<2$ & 16 & $<4$ & 24 & 10 & 176 & 18 & 6 & 34 & $<3$ & 25 & $<2$ & $<5$ & 66 & $<40$ \\
\hline 98ZA-11B & 50 & $<2$ & 42 & $<4$ & 74 & 99 & 394 & 10 & 16 & 75 & $<3$ & 3320 & $<2$ & $<5$ & 210 & $<40$ \\
\hline 98ZA-13 & 15 & $<2$ & 10 & $<4$ & 19 & 206 & 57 & 3 & 6 & 17 & $<3$ & 13 & $<2$ & $<5$ & 14 & $<40$ \\
\hline 98ZA-14 & 74 & $<2$ & 7 & $<4$ & 13 & 76 & 3690 & $<2$ & 13 & 20 & 22 & 9 & 18 & $<5$ & 260 & $<40$ \\
\hline 98ZA-16 & 3 & $<2$ & 23 & $<4$ & 30 & 19 & 561 & $<2$ & 24 & 28 & $<3$ & 11 & $<2$ & $<5$ & 56 & $<40$ \\
\hline 98ZA-17 & 77 & $<2$ & 24 & $<4$ & 13 & 29 & 2240 & $<2$ & 16 & 21 & 28 & 10 & 14 & $<5$ & 911 & $<40$ \\
\hline ZAR\#1-10 & 222 & $<2$ & 12 & $<4$ & 5 & 66 & 384 & 6 & 5 & $<9$ & 16 & 13 & 7 & $<5$ & 233 & $<40$ \\
\hline ZAR\#2-04 & 148 & 3 & 20 & $<4$ & 7 & 46 & 402 & $<2$ & 13 & 30 & 68 & $<4$ & 30 & $<5$ & 84 & $<40$ \\
\hline 92ZA-04 & 24 & 4 & 9 & $<8$ & 460 & $<4$ & 8000 & 24 & 30 & 190 & 8 & 1300 & 6 & $<10$ & 360 & $<80$ \\
\hline 92ZA-05 & 36 & $<4$ & 20 & $<8$ & 40 & 22 & 1400 & 4 & 10 & 20 & 9 & 180 & $<4$ & $<10$ & 340 & $<80$ \\
\hline 92ZA-06 & 10 & $<4$ & 10 & $<8$ & 31 & $<4$ & 2600 & $<4$ & 10 & 21 & 5 & $<8$ & 10 & $<10$ & 380 & $<80$ \\
\hline 92ZA-07 & 5 & $<4$ & 9 & $<8$ & 29 & $<4$ & 3800 & 6 & $<8$ & 10 & 8 & $<8$ & 4 & $<10$ & 380 & $<80$ \\
\hline 92ZA-08 & $<2$ & $<4$ & $<8$ & $<8$ & 10 & $<4$ & 4300 & $<4$ & $<8$ & $<8$ & 5 & $<8$ & $<4$ & $<10$ & 270 & $<80$ \\
\hline 92ZA-09 & 89 & $<4$ & 20 & $<8$ & 77 & 61 & 1100 & $<4$ & 29 & 73 & 24 & 29 & 20 & $<10$ & 730 & $<80$ \\
\hline $92 Z A-10$ & 5 & 5 & 9 & $<8$ & 280 & $<4$ & 3200 & $<4$ & $<8$ & 110 & $<4$ & 20 & 79 & $<10$ & 930 & $<80$ \\
\hline 92ZA-11 & 76 & 5 & 8 & $<8$ & 300 & $<4$ & 7700 & 150 & 33 & 160 & 54 & 28 & 5 & $<10$ & 1700 & $<80$ \\
\hline 92ZA-12 & 16 & $<2$ & 22 & $<4$ & 68 & 63 & 3700 & 350 & 240 & 47 & 19 & $<4$ & $<2$ & $<5$ & 880 & $<40$ \\
\hline 92ZA-13 & 16 & 3 & 28 & $<4$ & 160 & 110 & 2900 & 73 & 500 & 110 & 44 & 12 & 3 & $<5$ & 650 & $<40$ \\
\hline 93DC-07 & 3 & $<4$ & 15 & $<8$ & 28 & 100 & 110 & $<4$ & 16 & 24 & $<4$ & $<8$ & $<4$ & $<10$ & 58 & $<80$ \\
\hline 93DC-08 & 110 & $<4$ & 18 & $<8$ & 14 & 56 & 850 & $<4$ & 16 & 11 & 10 & $<8$ & 31 & $<10$ & 130 & $<80$ \\
\hline 93DC-09 & $<2$ & $<4$ & 12 & $<8$ & 8 & 38 & 1100 & $<4$ & 9 & 15 & 230 & $<8$ & 29 & $<10$ & 310 & $<80$ \\
\hline 93DC-10 & 270 & $<4$ & $<8$ & $<8$ & 7 & $<4$ & 620 & $<4$ & $<8$ & 8 & 18 & 10 & 8 & $<10$ & 120 & $<80$ \\
\hline 93DC-11 & 160 & $<4$ & $<8$ & $<8$ & $<4$ & 7 & 610 & $<4$ & $<8$ & $<8$ & 35 & 12000 & 13 & $<10$ & 210 & $<80$ \\
\hline 93DC-16 & 120 & $<4$ & 9 & $<8$ & $<4$ & $<4$ & 1800 & $<4$ & $<8$ & $<8$ & 36 & 3100 & 10 & $<10$ & 33 & $<80$ \\
\hline 93DC-17 & 130 & $<4$ & $<8$ & $<8$ & $<4$ & $<4$ & 72 & $<4$ & $<8$ & $<8$ & 43 & 9900 & $<4$ & $<10$ & 4 & $<80$ \\
\hline 93DC-18 & 43 & $<4$ & 11 & $<8$ & 8 & 5 & 5100 & $<4$ & $<8$ & $<8$ & 32 & 1800 & 12 & $<10$ & 72 & $<80$ \\
\hline 93DC-19 & 10 & $<4$ & $<8$ & $<8$ & $<4$ & 5 & 1500 & $<4$ & $<8$ & $<8$ & 4 & $<8$ & $<4$ & $<10$ & 320 & $<80$ \\
\hline 93DC-20 & 460 & $<4$ & $<8$ & $<8$ & $<4$ & $<4$ & 14 & 6 & $<8$ & $<8$ & $<4$ & 3200 & $<4$ & $<10$ & 650 & $<80$ \\
\hline 93DC-24B & 490 & $<4$ & $<8$ & $<8$ & $<4$ & $<4$ & 63 & 5 & $<8$ & $<8$ & 6 & 1400 & $<4$ & $<10$ & 310 & $<80$ \\
\hline 93DC-26 & 55 & $<4$ & $<8$ & $<8$ & 4 & 16 & 1900 & $<4$ & $<8$ & 9 & 25 & $<8$ & 17 & $<10$ & 420 & $<80$ \\
\hline 93DC-42 & 63 & $<4$ & $<8$ & $<8$ & $<4$ & $<4$ & 1400 & $<4$ & $<8$ & $<8$ & 16 & $<8$ & 5 & $<10$ & 300 & $<80$ \\
\hline 93ZA-14 & 8500 & $<4$ & $<8$ & $<8$ & 19 & $<4$ & 73 & 38 & $<8$ & 21 & 5 & 110 & $<4$ & $<10$ & 440 & $<80$ \\
\hline 93ZA-15 & 5800 & $<4$ & $<8$ & $<8$ & 8 & $<4$ & 47 & 12 & $<8$ & $<8$ & 6 & 580 & $<4$ & $<10$ & 490 & $<80$ \\
\hline 93ZA-16 & 830 & $<4$ & $<8$ & $<8$ & 38 & $<4$ & 140 & 5 & $<8$ & 34 & $<4$ & 170 & $<4$ & $<10$ & 780 & $<80$ \\
\hline
\end{tabular}

Key: qtz=qu

sph=sphale

porph=porp 


\begin{tabular}{|c|c|c|c|c|c|c|c|}
\hline Sample \# & $\begin{array}{r}\text { C_ICP40 } \\
\text { Th }\end{array}$ & $\begin{array}{r}\text { C_ICP40 } \\
\text { U }\end{array}$ & $\begin{array}{r}\text { C_ICP40 } \\
\text { V }\end{array}$ & $\begin{array}{r}\text { C_ICP40 } \\
Y\end{array}$ & $\begin{array}{r}\text { C_ICP40 } \\
\text { Yb }\end{array}$ & $\begin{array}{r}\text { C_ICP40 } \\
\text { Zn }\end{array}$ & $\begin{array}{r}\text { C_CO2 C C_CO2 C } \\
\text { CO2 CRBNT_C }\end{array}$ \\
\hline & ppm & ppm & $\mathrm{ppm}$ & ppm & ppm & ppm & $\%$ \\
\hline 98ZA-04 & 7 & $<100$ & 16 & 11 & 2 & 34740 & \\
\hline 98ZA-07 & $<6$ & $<100$ & 24 & 8 & $<1$ & 15890 & \\
\hline 98ZA-09 & $<6$ & $<100$ & 8 & 19 & 1 & 20270 & \\
\hline 98ZA-11B & 20 & $<100$ & 6 & 76 & 8 & 19330 & \\
\hline 98ZA-13 & 7 & $<100$ & 15 & 12 & 1 & 112 & \\
\hline $98 Z A-14$ & 8 & $<100$ & 232 & 16 & 3 & 162 & \\
\hline 98ZA-16 & 7 & $<100$ & 12 & 16 & 1 & 134 & \\
\hline 98ZA-17 & $<6$ & $<100$ & 206 & 18 & 3 & 124 & \\
\hline ZAR\#1-10 & $<6$ & $<100$ & 73 & 16 & 2 & 65 & \\
\hline ZAR\#2-04 & $<6$ & $<100$ & 320 & 16 & 2 & 81 & \\
\hline 92ZA-04 & $<8$ & $<200$ & 10 & 40 & 6 & 5200 & - \\
\hline 92ZA-05 & $<8$ & $<200$ & 190 & 5 & $<2$ & 1000 & - \\
\hline 92ZA-06 & $<8$ & $<200$ & 35 & 33 & 3 & 22 & - \\
\hline 92ZA-07 & $<8$ & $<200$ & 66 & 10 & $<2$ & 24 & - \\
\hline 92ZA-08 & $<8$ & $<200$ & 29 & 20 & $<2$ & 24 & - \\
\hline 92ZA-09 & 10 & $<200$ & 220 & 36 & 3 & 130 & - \\
\hline 92ZA-10 & 10 & $<200$ & 230 & 97 & 10 & 25 & - \\
\hline 92ZA-11 & $<8$ & $<200$ & 8 & 52 & 6 & 130 & - \\
\hline 92ZA-12 & 6 & $<100$ & 260 & 18 & 1 & 250 & \\
\hline 92ZA-13 & $<4$ & $<100$ & 300 & 19 & 1 & 860 & \\
\hline 93DC-07 & $<8$ & $<200$ & 8 & 15 & 3 & 10 & $<0.01$ \\
\hline 93DC-08 & $<8$ & $<200$ & 310 & 9 & $<2$ & 80 & 17.5 \\
\hline 93DC-09 & $<8$ & $<200$ & 190 & 9 & $<2$ & 54 & 21.3 \\
\hline 93DC-10 & $<8$ & $<200$ & 60 & 10 & 3 & 77 & - \\
\hline 93DC-11 & $<8$ & $<200$ & 110 & 4 & $<2$ & 4200 & 20.0 \\
\hline 93DC-16 & $<8$ & $<200$ & 64 & $<4$ & $<2$ & 35000 & - \\
\hline 93DC-17 & $<8$ & $<200$ & $<4$ & $<4$ & $<2$ & 2000 & - \\
\hline 93DC-18 & $<8$ & $<200$ & 100 & 10 & 2 & 5400 & - \\
\hline 93DC-19 & $<8$ & $<200$ & 52 & 7 & $<2$ & 14 & 22.8 \\
\hline 93DC-20 & $<8$ & $<200$ & $<4$ & $<4$ & $<2$ & 15000 & - \\
\hline 93DC-24B & $<8$ & $<200$ & 7 & $<4$ & $<2$ & 11000 & - \\
\hline 93DC-26 & $<8$ & $<200$ & 170 & 15 & $<2$ & 39 & 32.1 \\
\hline 93DC-42 & $<8$ & $<200$ & 8 & 5 & $<2$ & 21 & \\
\hline 93ZA-14 & $<8$ & $<200$ & $<4$ & 28 & $<2$ & 20000 & \\
\hline 93ZA-15 & $<8$ & $<200$ & 5 & $<4$ & $<2$ & 100000 & \\
\hline $93 Z A-16$ & $<8$ & $<200$ & 20 & 19 & $<2$ & 80000 & \\
\hline
\end{tabular}


Table 4. Major characteristics of mineral occurrences in the Stikine Geophysical Survey Project area.

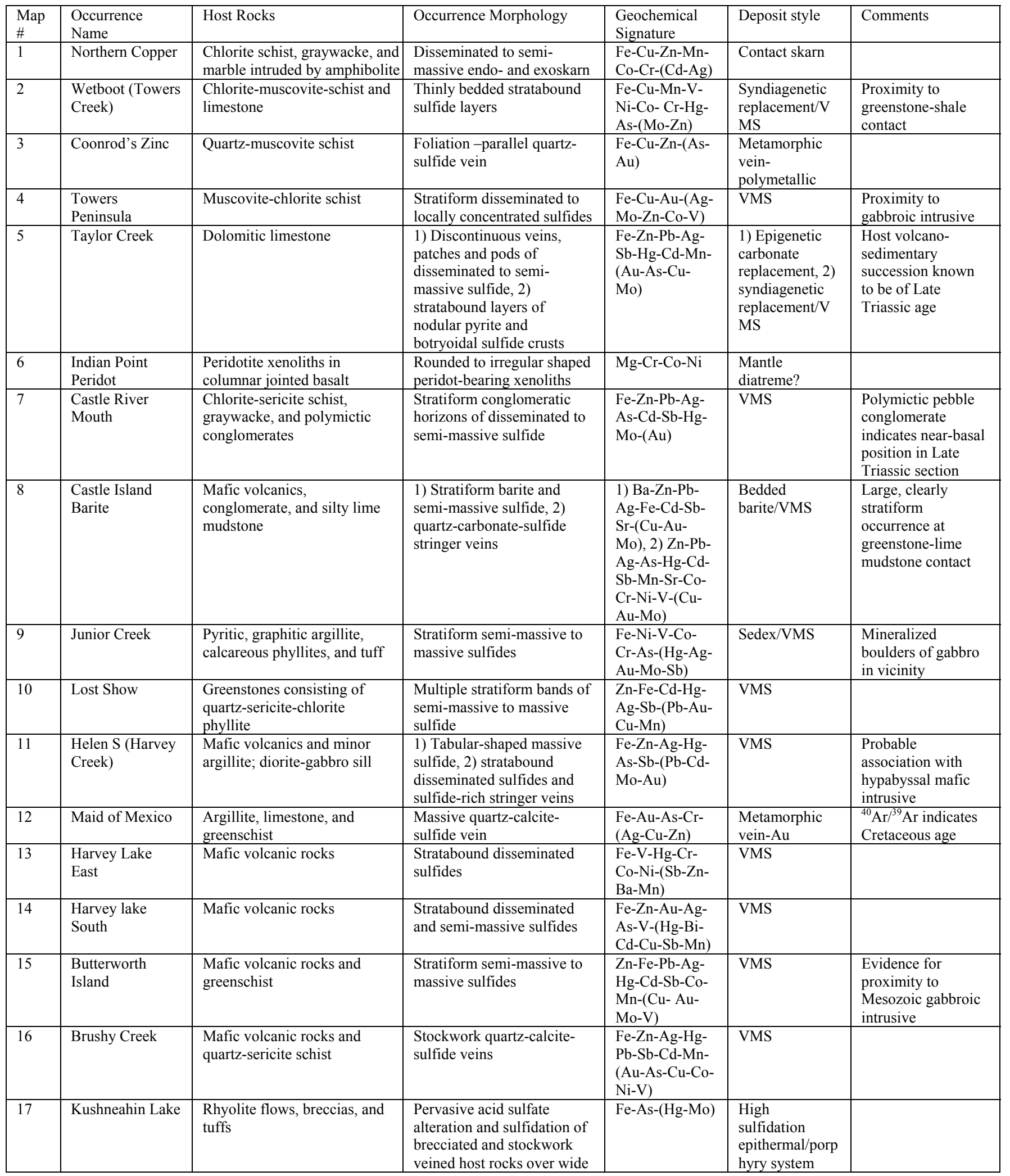




\begin{tabular}{|c|c|c|c|c|c|c|}
\hline & & & area & & & \\
\hline 18 & $\begin{array}{l}\text { St. John's } \\
\text { Fluorite }\end{array}$ & $\begin{array}{l}\text { Argillite intruded by basaltic } \\
\text { dikes and sills or flows }\end{array}$ & $\begin{array}{l}\text { Multiple veinlets and } \\
\text { fractures filled with quartz- } \\
\text { fluorite }\end{array}$ & $\mathrm{F}$ & Vein fluorite & \\
\hline 19 & $\begin{array}{l}\text { Frenchie (St. } \\
\text { John Harbor) }\end{array}$ & $\begin{array}{l}\text { Argillite, muscovite schist, } \\
\text { muscovite-chlorite schist, } \\
\text { mafic volcanics and tuff, } \\
\text { basaltic and gabbroic sills }\end{array}$ & $\begin{array}{l}\text { 1) Stratiform massive } \\
\text { sulfide, 2) quartz-carbonate- } \\
\text { fluorite-pyrite veinlets }\end{array}$ & $\begin{array}{l}\text { 1) Fe-Zn-Cu- } \\
\mathrm{Au}-(\mathrm{Hg}-\mathrm{Ag}-\mathrm{As}- \\
\mathrm{Cd}-\mathrm{Mo}-\mathrm{Pb}-\mathrm{Sb} \text { ), } \\
\text { 2) F-Cu-Au- } \\
\mathrm{Ag}-\mathrm{As}\end{array}$ & $\begin{array}{l}\text { 1) VMS, 2) } \\
\text { Vein } \\
\text { fluorite/alkaline } \\
\text { copper-gold? }\end{array}$ & $\begin{array}{l}\text { Proximity to } \\
\text { greenstone-argillite } \\
\text { contact. Gabbroic } \\
\text { sills in footwall }\end{array}$ \\
\hline 20 & Hydropit & $\begin{array}{l}\text { Quartz diorite; felsic, } \\
\text { intermediate, and mafic dikes }\end{array}$ & $\begin{array}{l}\text { Vein and disseminated } \\
\text { sulfides }\end{array}$ & $\begin{array}{l}\mathrm{Pb}-\mathrm{Cu}-\mathrm{Zn}-\mathrm{Ag}- \\
\mathrm{Cd}-\mathrm{Sn}-\mathrm{W}-(\mathrm{Bi}- \\
\mathrm{Mo})\end{array}$ & $\begin{array}{l}\text { Magmato- } \\
\text { hydrothermal } \\
\text { vein }\end{array}$ & \\
\hline 21 & Lost Zarembo & $\begin{array}{l}\text { Quartz-sericite-chlorite schist; } \\
\text { gabbro and rhyolite dikes }\end{array}$ & $\begin{array}{l}\text { Stratiform semi-massive } \\
\text { sulfides }\end{array}$ & $\begin{array}{l}\mathrm{Fe}-\mathrm{Zn}-\mathrm{Ag}-(\mathrm{Cu}- \\
\mathrm{Pb}-\mathrm{Au}-\mathrm{Cd})\end{array}$ & VMS & $\begin{array}{l}\text { Proximity to } \\
\text { gabbroic dikes }\end{array}$ \\
\hline 22 & $\begin{array}{l}\text { Bay Point U-Th- } \\
\text { REE }\end{array}$ & $\begin{array}{l}\text { Graywacke, basalt, basaltic } \\
\text { dikes }\end{array}$ & $\begin{array}{l}\text { Sulfide-bearing carbonatite } \\
\text { veins and associated } \\
\text { carbonatized host rocks }\end{array}$ & $\begin{array}{l}\text { U-Th-Ce-La- } \\
\text { Mn-Sr-Nb-Nd- } \\
\text { Y-Zn-Pb }\end{array}$ & $\begin{array}{l}\text { U-Th-REE- } \\
\text { bearing } \\
\text { carbonatite }\end{array}$ & \\
\hline 23 & Round Point & $\begin{array}{l}\text { Quartz-sericite-chlorite-pyrite } \\
\text { schist interbedded with } \\
\text { limestone and argillite; } \\
\text { basaltic dike }\end{array}$ & $\begin{array}{l}\text { Stratiform semi-massive } \\
\text { sulfide }\end{array}$ & $\begin{array}{l}\text { Fe-Zn-Cu-Ag- } \\
\text { Cd-(Au-Hg-Sb- } \\
\text { Bi-Mo) }\end{array}$ & VMS & $\begin{array}{l}\text { Proximity to } \\
\text { basaltic dike }\end{array}$ \\
\hline 24 & $\begin{array}{l}\text { Snow Passage } \\
\text { Fluorite }\end{array}$ & Rhyolite and rhyolite tuffs & $\begin{array}{l}\text { Quartz-fluorite-pyrite } \\
\text { veinlets }\end{array}$ & $\begin{array}{l}\text { F-Fe-As-(Au- } \\
\mathrm{Mo})\end{array}$ & Vein fluorite & \\
\hline 25 & $\begin{array}{l}\text { SE Zarembo } \\
\text { Siliceous Breccia }\end{array}$ & $\begin{array}{l}\text { Greenschist and sediments; } \\
\text { alkaline granite }\end{array}$ & $\begin{array}{l}\text { Restricted circular area of } \\
\text { silicified heterolithic, clast- } \\
\text { supported breccia }\end{array}$ & $\begin{array}{l}\text { Li-(Au-Ag-Mo- } \\
\mathrm{Sb})\end{array}$ & $\begin{array}{l}\text { Late-stage } \\
\text { magmato- } \\
\text { thermal vent } \\
\text { breccia } \\
\end{array}$ & \\
\hline
\end{tabular}

Key: VMS=Volcanogenic Massive Sulfide, Sedex=Sedimentary exhalative massive sulfide. 